\title{
Water-Resources Reports Prepared by or in Cooperation with the U.S. Geological Survey, Kansas, 1886-1994
}

Compiled by DONNA J. ROBERTS and LANNA J. COMBS

\section{U.S. GEOLOGICAL SURVEY}

Open-File Report 95-120

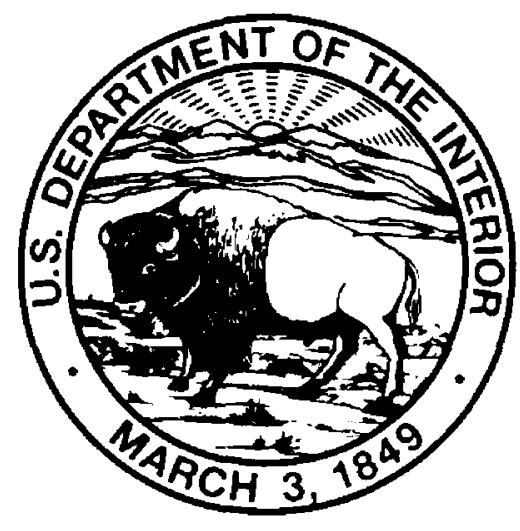




\section{U.S. DEPARTMENT OF THE INTERIOR \\ BRUCE BABBITT, Secretary}

U.S. GEOLOGICAL SURVEY

GORDON P. EATON, Director

For additional information write to:

Copies of this report can be purchased from:

U.S. Geological Survey

Earth Science Information Center

District Chief

U.S. Geological Survey

Open-File Reports Section

4821 Quail Crest Place

Box 25286, MS 517

Denver Federal Center

Lawrence, Kansas 66049-3839

Denver, Colorado 80225 


\section{CONTENTS}

Introduction . .

Purpose

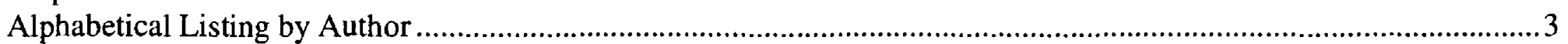

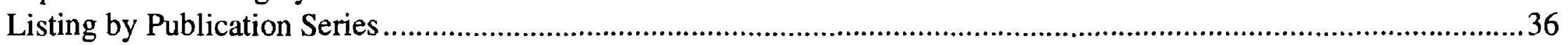

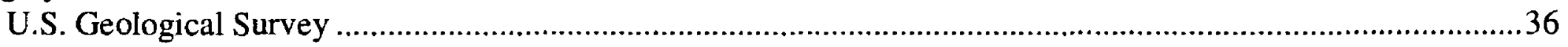

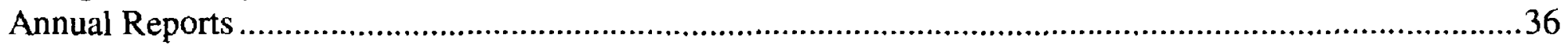

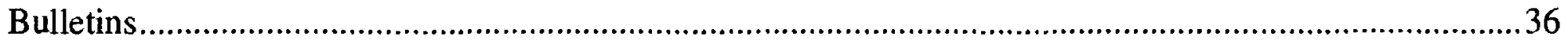

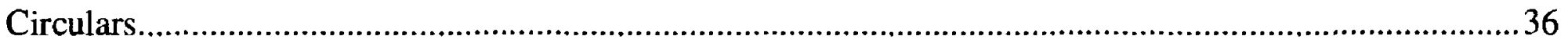

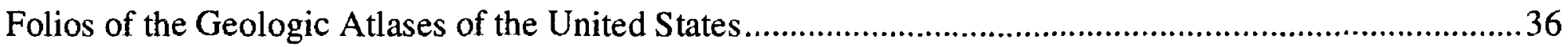

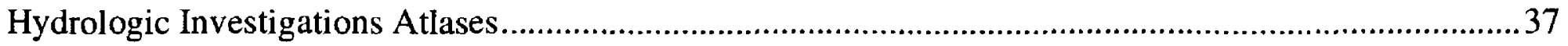

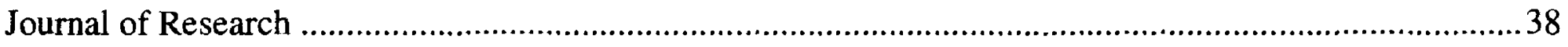

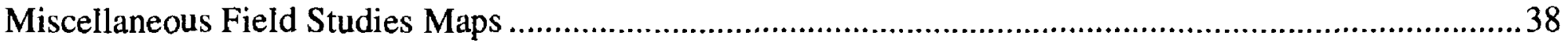

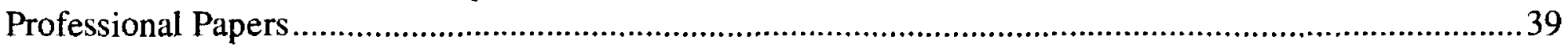

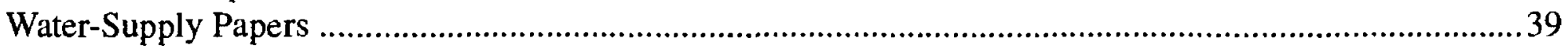

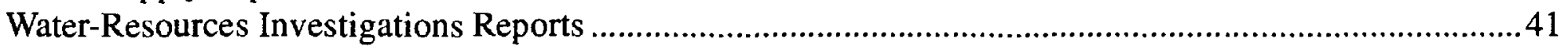

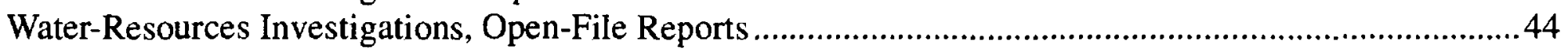

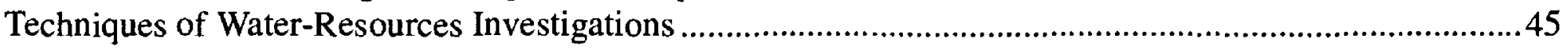

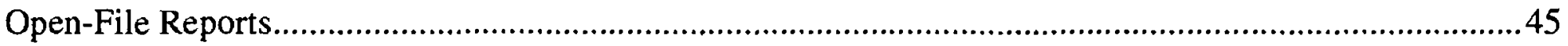

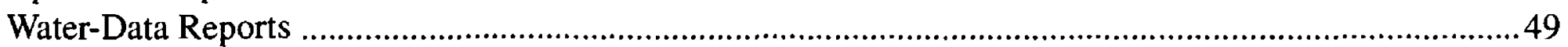

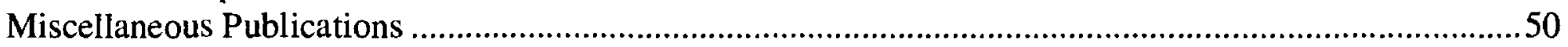

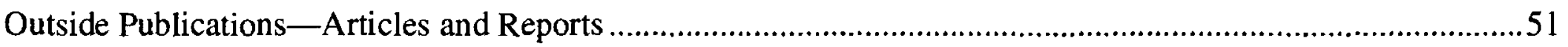

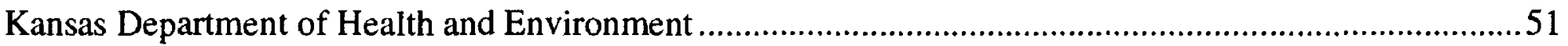

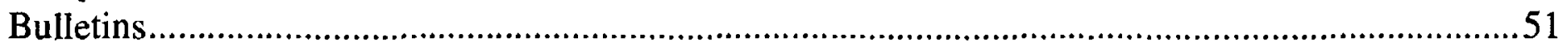

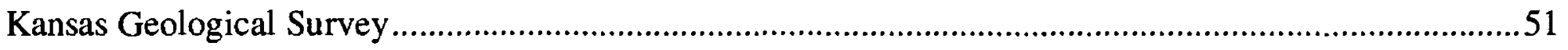

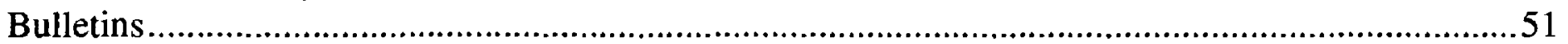

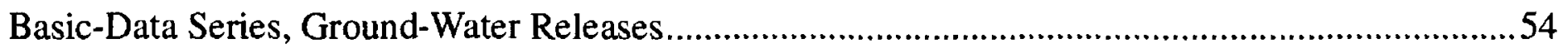

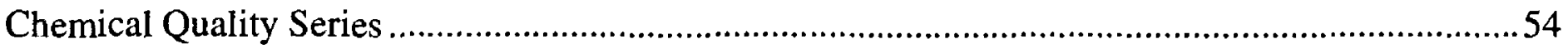

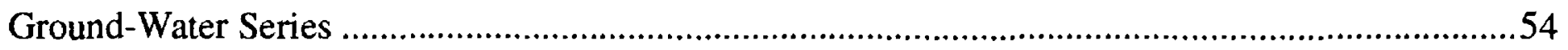

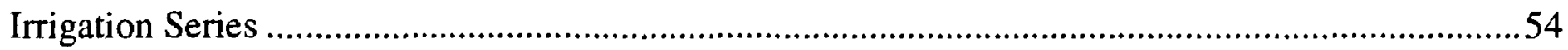

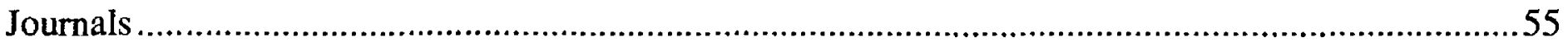

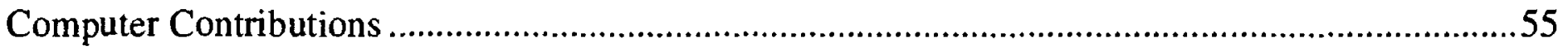

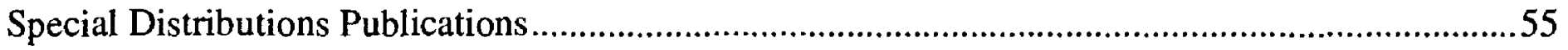

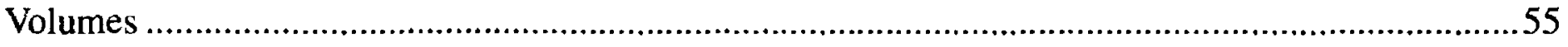

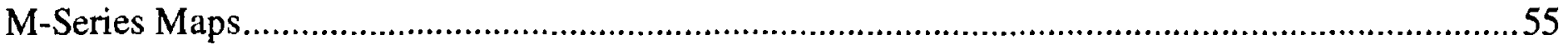

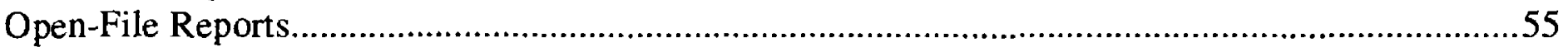

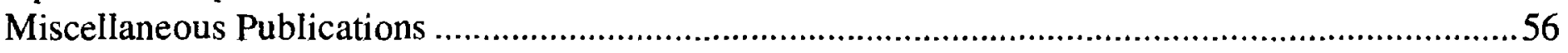

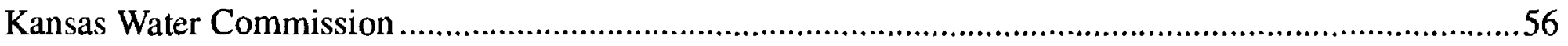

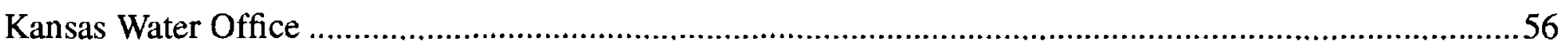

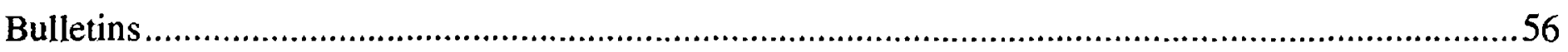

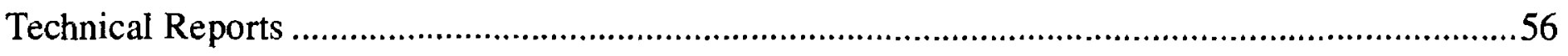

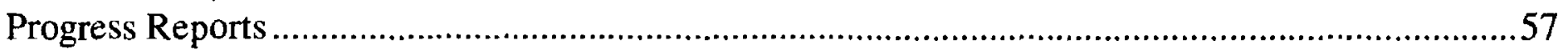

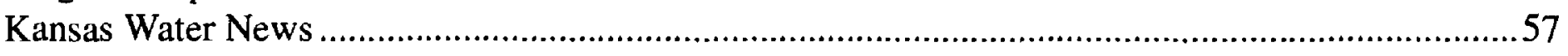

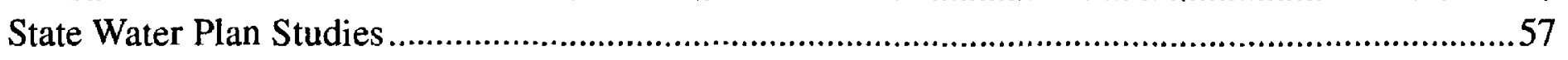

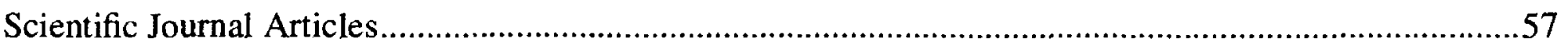

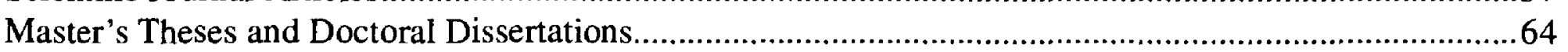

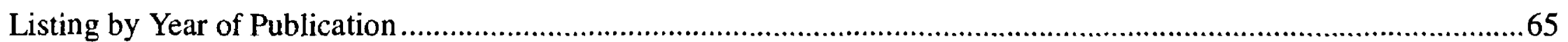

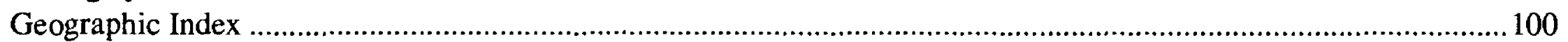

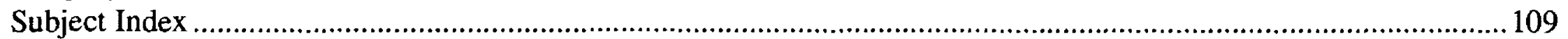




\section{FIGURE}

1. Map showing location of offices of the U.S. Geological Survey in Kansas ......................................................2

CONVERSION FACTORS

\begin{tabular}{rll}
\hline Multiply & By & To obtain \\
\hline inch & 2.54 & centimeter \\
mile & 1.609 & kilometer \\
\hline
\end{tabular}




\title{
Water-Resources Reports Prepared by or in Cooperation with the U.S. Geological Survey, Kansas, 1886-1994
}

\author{
Compiled by Donna J. Roberts and Lanna J. Combs
}

\section{INTRODUCTION}

The Organic Act of March 3, 1879, established the U.S. Geological Survey as a separate Bureau of the Department of the Interior. The Survey's principal mission became (1) the classification and survey of public lands, (2) the examination of the geologic structure and the mineral resources of the national domain, and (3) the determination of the water resources of the United States. Seven years later, in 1886, the first water-resources investigation by the U.S. Geological Survey in Kansas was completed by A.C. Peale.

From this early beginning, the Water Resources Division of the U.S. Geological Survey has met the growing demand for scientific data by Federal, State, and local agencies for use in the planning and management of one of the most precious resources of Kansas-water. The Kansas District of the Water Resources Division, with headquarters in Lawrence and field offices in Lawrence, Garden City, and Wichita (fig. 1), continues to investigate the occurrence, quantity, quality, distribution, and movement of surface and ground waters. Its activities still include the systematic collection, analysis, and interpretation of hydrologic data; the investigation of water demand for public supply, industrial, domestic, and agricultural purposes; and the research and development of new techniques to improve the scientific basis of water data collection and investigative principles.

Moneys for program operation of the U.S. Geological Survey in Kansas have come from jointfunding agreements with State and local agencies, transfer of funds from other Federal agencies, and direct Federal allotments to the U.S. Geological Survey.
Water-resources data and the results of hydrologic investigations in Kansas are published or released either by the U.S. Geological Survey, by cooperating agencies, or by journals of technical and scientific organizations. Requests for publications resulting from investigations of the U.S. Geological Survey in Kansas should be addressed to:

$$
\begin{gathered}
\text { District Chief } \\
\text { U.S. Geological Survey } \\
\text { Water Resources Division } \\
4821 \text { Quail Crest Place } \\
\text { Lawrence, Kansas } 66049 \\
\text { Telephone: (913) 842-9909 }
\end{gathered}
$$

Book reports or maps that are out of print [as indicated by an asterisk $(*)$ in the accompanying lists] can no longer be purchased from any official source but may be consulted at many public- or educationalinstitution libraries throughout the country and at USGS offices.

\section{PURPOSE}

The purpose of this bibliography is to help locate the more than 1,000 reports and abstracts prepared by or in cooperation with the U.S. Geological Survey in Kansas and published during the period of 1886 to 1994 . The bibliography is formatted to make location of publications possible without having a complete reference. The complete reference is listed only in the "Alphabetical Listing by Author" section. The other sections of the report have enough information for the reader to refer back to the "Alphabetical Listing by Author" section for the complete reference. The bibliography is divided into five sections:

(1) Alphabetical Listing by Author, (2) Listing by Publication Series, (3) Listing by Year of Publication, (4) Geographic Index, and (5) Subject Index. 


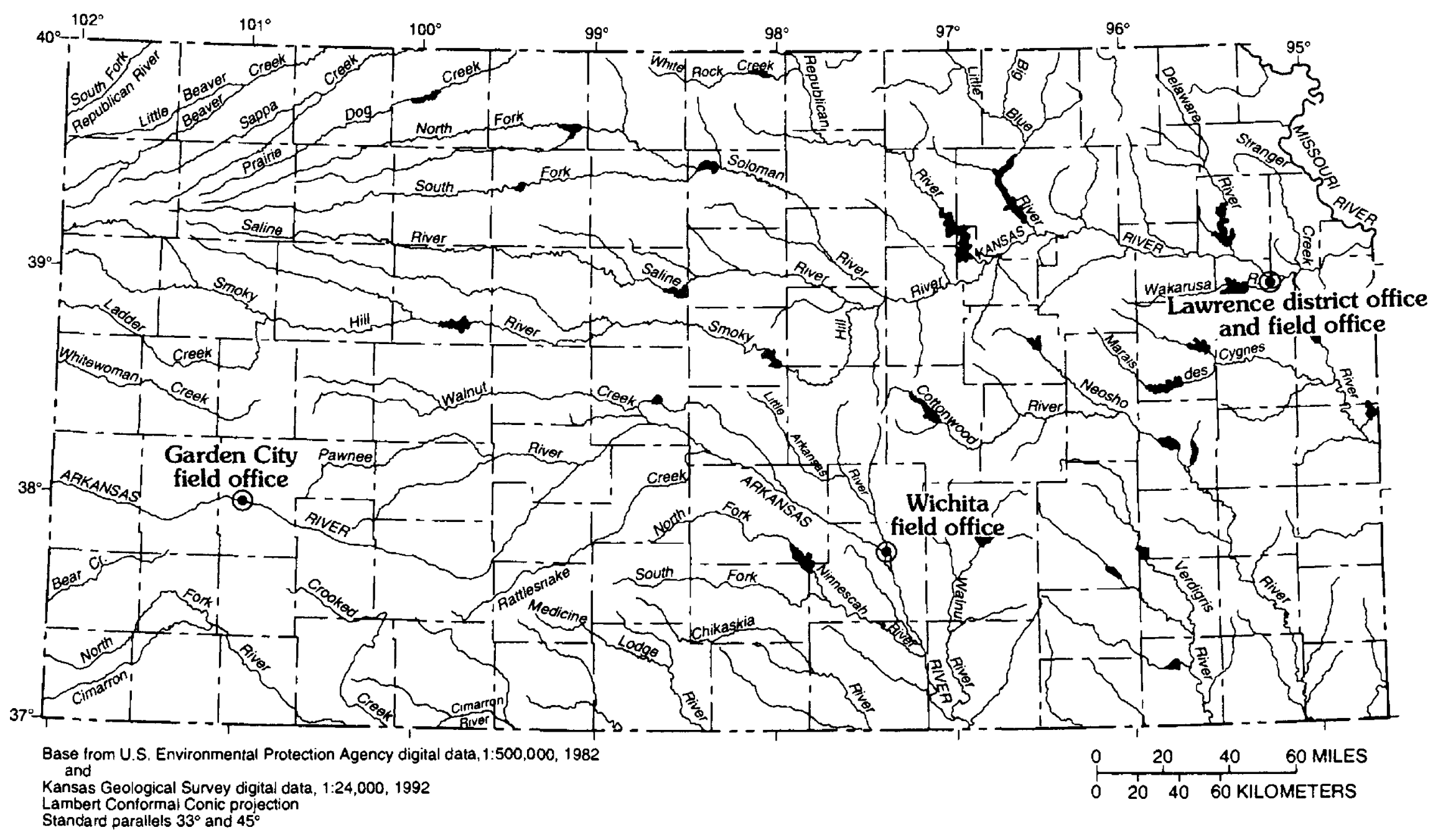

Figure 1. Location of offices of the U.S. Geological Survey in Kansas. 


\section{ALPHABETICAL LISTING BY AUTHOR}

This index is used when you know the name of a publication's author. The index is arranged alphabetically by the author's last name and initials, and then chronologically by publication year. For author listings with more than one publication in a given year, the letters "a," "b," "c," and so forth are added after the year.

Adams, C.D., 1991, Ozonation of atrazine-A kinetic model and byproduct formation in natural waters: Lawrence, University of Kansas, Ph.D. dissertation, $242 \mathrm{p}$.

Adams, C.D., Randtke, C.D., Thurman, E.M., and Hulsey, R.A., 1990, Atrazine and its degradation products in soil and ground water, and the effectiveness of water-treatment processes for their removal, in Proceedings from the 40th Annual University of Kansas Environmental Engineering Conference, Lawrence, Kans., February 7, 1990: Lawrence, University of Kansas, Department of Environmental Engineering, $24 \mathrm{p}$.

Adams, C.D., and Thurman, E.M., 1991, Formation and transport of deethylatrazine in the soil and vadose zone: Journal of Environmental Quality, v. 20, no. 3, July-September 1991, p. 540-547.

Aga, D.S., and Thurman, E.M., 1993a, Chromatographic application of solid-phase extraction in developing immunoassay methods for herbicides and their metabolites-An example for alachlor and alachlor ethanesulfonic acid [abs.], in Programs and proceedings of symposium on agricultural nonpoint sources of contaminants-Focus on herbicides, Lawrence, Kans., September 28-29, 1993: U.S. Environmental Protection Agency, Region VII, and U.S. Geological Survey, p. 38.

1993b, Coupling solid-phase extraction (SPE) and enzyme-linked immunosorbent assay (ELISA) for ultratrace analysis of herbicides in pristine water: Analytical Chemistry, v. 65, p. 2894-2898.

Aga, D.S., Thurman, E.M., and Pomes, M.L., 1993, Measurement of concentrations of alachlor and its ethanesulfonic acid metabolite in water by solidphase extraction and enzyme-linked immunosorbent assay [abs.], in Morganwalp, D.W., and Aronson, D.A., compilers, U.S. Geological Survey Toxic Substances Hydrology Program-Abstracts of the Technical Meeting, Colorado Springs, Colo., September 20-24, 1993: U.S. Geological Survey Open-File Report 93-454, p. 80.

1994, Determination of alachlor and its ethanesulfonic acid metabolite in water by solid-phase extraction and enzyme-linked immunosorbent assay: Analytical Chemistry, v. 66, no. 9, May I, 1994, p. 1495-1499.
Albert, C.D., 1962, Sediment investigations in Kansas: Kansas Water News, v. 5, no. 4, p. 5-7.

1964, Brine in surface water of the Little Arkansas River Basin, Kansas: Kansas Department of Health and Environment Bulletin No. 1-5, 15 p.

1969, Total sediment discharge of selected streams in Kansas, 1957-65, a compilation: Kansas Water Resources Board Bulletin No. 10,8 p.

1973, Fluvial sediment characteristics of the Kansas River at Wamego, Kansas, 1957-70: U.S. Geological Survey Open-File Report, 13 p.

*Albert, C.D., and Stramel, G.J., 1966, Fluvial sediment in the Little Arkansas River Basin, Kansas: U.S. Geological Survey Water-Supply Paper 1798-B, p. B1-B30.

Albin, D.R., 1975, Water resources alternative study areas, proposed Prairie National Park, Kansas-Oklahoma, in Preliminary environmental assessment, alternative study areas, proposed Prairie National Park, KansasOklahoma (appendix D): U.S. Department of Interior, National Park Service, 32 p.

Angino, E.E., and Morgan, C.O., 1966, Application of pattern analysis to the classification of oil-field brines, in Merriam, D.F., ed., Computer applications in the earth sciences-Colloquium on classification procedures: Kansas Geological Survey Computer Contributions Series 7, p. 53-56.

Baker, C.H., Jr., 1979, Evaluation of methods for estimating ground-water withdrawals in western Kansas: U.S. Geological Survey Water-Resources Investigations Report 79-92, 70 p.

1983, Evaluation of techniques for estimating ground-water withdrawals for irrigation in western Kansas: Kansas Water Office Bulletin No. 26, 14 p.

Baker, C.H., Jr., and Hansen, C.V., 1987, Kansas groundwater quality: U.S. Geological Survey Open-File Report 87-726, 7 p.

1988, Kansas ground-water quality, in Moody, D.W., Carr, Jerry, Chase, E.B., and Paulson, R.W., compilers, National water summary 1986-Hydrologic events and ground-water quality: U.S. Geological Survey Water-Supply Paper 2325, p. 259-264. 
Baker, C.H., Jr., and Kenny, J.F., 1990, Kansas water supply and use, in Carr, Jerry, Chase, E.B., Paulson, R.W., and Moody, D.W., compilers, National water summary 1987-Water supply and use: U.S. Geological Survey Water-Supply Paper 2350, p. 259-266.

Barker, R.A., Dunlap, L.E., and Sauer, C.G., 1981, Analysis and computer simulation of stream-aquifer hydrology, Arkansas River Valley, southwestern Kansas: U.S. Geological Survey Open-File Report 81-686, $130 \mathrm{p}$.

1983, Analysis and computer simulation of streamaquifer hydrology, Arkansas River Valley, southwestern Kansas: U.S. Geological Survey WaterSupply Paper 2200, 59 p.

Barnes, Philip, and Perry, C.A., 1990, Herbicide transport in runoff from agricultural fields in Kansas: Proceedings of 7 th Annual Water and the Future of Kansas Conference, Manhattan, Kans., March 7-8, 1990, p. 23-24.

Bayne, C.K., 1956a, Geology and ground-water resources of Reno County, Kansas: Kansas Geological Survey Bulletin 120, $130 \mathrm{p}$.

1956b, Geology and ground-water resources of Sheridan County, Kansas: Kansas Geological Survey Bulletin 116, $94 \mathrm{p}$.

1958, Ground-water resources of Elk County, Kansas: Kansas Geological Survey, v. 14, pt. 3, p. 37-56.

1960, Geology and ground-water resources of Harper County, Kansas: Kansas Geological Survey Bulletin 143, 183 p.

1962, Geology and ground-water resources of Cowley County, Kansas: Kansas Geological Survey Bulletin 158, $219 \mathrm{p}$.

1971, Geohydrology of Doniphan County, northeastern Kansas: U.S. Geological Survey Open-File Report, $21 \mathrm{p}$.

1973, Geohydrology of Doniphan County, northeastern Kansas: U.S. Geological Survey Hydrologic lnvestigations Atlas HA-462, 1 sheet, scale 1:62,500.

Bayne, C.K., Franks, P.C., and Ives, William, Jr., 1971 , Geology and ground-water resources of Ellsworth County, central Kansas: Kansas Geological Survey Bulletin 201, 84 p.

Bayne, C.K., and Schoewe, W.H., 1967, Geology and ground-water resources of Brown County, Kansas: Kansas Geological Survey Bulletin 186, 68 p.

Bayne, C.K., and Walters, K.L., 1959, Geology and ground-water resources of Cloud County, Kansas: Kansas Geological Survey Bulletin 139, 144 p.

*Bayne, C.K., and Ward, J.R., compilers, 1967, General availability of ground water in Kansas: Kansas Geological Survey Map M-4, 1 sheet, scale 1:500,000.
1969, Saturated thickness and specific yield of Cenozoic deposits in Kansas: Kansas Geological Survey Map M-5, 1 sheet, scale 1:500,000.

1974, Geology and hydrology of Rice County, central Kansas: Kansas Geological Survey Bulletin 206, pt. 3, $17 \mathrm{p}$.

Bedinger, M.S., and Tanaka, H.H., 1962, Effect of the Kirwin reservoir, Kansas, on ground-water levels: U.S. Geological Survey Open-File Report, 11 p.

Berry, D.W., 1952, Geology and ground-water resources of Lincoln County, Kansas, with a chapter on The chemical quality of ground water, by W.H. Durum: Kansas Geological Survey Bulletin 95, 96 p.

Bevans, H.E., 1980, A procedure for predicting concentrations of dissolved solids and sulfate ion in streams draining areas strip mined for coal: U.S. Geological Survey Water-Resources Investigations, Open-File Report 80-764, 17 p.

1982, Water-quality and fluvial-sediment characteristics of selected streams in northeast Kansas: U.S. Geological Survey Water-Resources Investigations Report 82-4005, 53 p.

1984, Hydrologic responses of streams to mining of the Mulberry coal reserves in eastern Kansas: U.S. Geological Survey Water-Resources Investigations Report 84-4047, 29 p.

1986, Estimating stream-aquifer interactions in coal areas of eastern Kansas by using streamflow records, in Seymour Subitzky, ed., Selected papers in the hydrologic sciences, 1986: U.S. Geological Survey WaterSupply Paper 2290, p. 51-64.

1988, Water supply and demand in Sedgwick County, Kansas: U.S. Geological Survey Open-File Report 88-711 (Water Fact Sheet), 2 p.

1989a, Interior province-Western region, in Britton, L.J., Anderson, C.L., Goolsby, D.A., and Van Haveren, B.P., eds., Summary of the U.S. Geological Survey and U.S. Bureau of Land Management National CoalHydrology Program, 1974-84: U.S. Geological Survey Professional Paper 1464, p. 53-61.

1989b, Water resources of Sedgwick County, Kansas: U.S. Geological Survey Water-Resources Investigations Report 88-4225, $119 \mathrm{p}$.

Bevans, H.E., and Diaz, A.M., 1980, Statistical summary of water-quality data for streams draining coal-mined areas, southeastern Kansas: U.S. Geological Survey Open-File Report 80-350, $113 \mathrm{p}$

Bevans, H.E., Fromm, C.H., and Watkins, S.A., 1993, The occurrence and transport of agricultural pesticides in the Tuttle Creek Lake-stream system, Kansas and Nebraska: U.S. Geological Survey Open-File Report 93-87, 44 p. 
Bevans, H.E., Skelton, John, Kenny, J.F., and Davis, J.V., 1984, Hydrology of area 39, Western Region, Interior Coal Province, Kansas and Missouri: U.S. Geological Survey Water-Resources Investigations, Open-File Report 83-851, 83 p.

Bevans, H.E., Spruill, T.B., and Kenny, J.F., 1985, Ground-water resources-Kansas, in National water summary 1984-Hydrologic events, selected waterquality trends, and ground-water resources: U.S. Geological Survey Water-Supply Paper 2275, p. 217-222.

Bradley, Edward, and Johnson, C.R., 1957, Groundwater resources of the Ladder Creek area in Kansas, with a section on The chemical quality of water, by R.A. Krieger: Kansas Geological Survey Bulletin 126, $194 \mathrm{p}$.

Brewer, L.D., Trombley, T.J., and Pomes, M.J., 1994, Water resources on and near Indian lands in northeastern Kansas and southeastern Nebraska-Hydrologic data through 1990: U.S. Geological Survey Open-File Report 94-35, 424 p.

*Broeker, M.E., and Fishel, V.C., 1961, Ground-water levels in observation wells in Kansas, 1960: Kansas Geological Survey Bulletin 153, 183 p.

* _ 1962, Ground-water levels in observation wells in Kansas, 1961: Kansas Geological Survey Bulletin 159, 165 p.

Broeker, M.E., McIntyre, H.J., Jr., and McNellis, J.M., 1977, Ground-water levels in observation wells in Kansas, 1971-75: Kansas Geological Survey BasicData Series, Ground-Water Release 6, 526 p.

Broeker, M.E., and McNellis, J.M., 1973, Ground-water levels in observation wells in Kansas, 1966-70: Kansas Geological Survey Basic-Data Series, GroundWater Release 3, 373 p.

*Broeker, M.E., and Winslow, J.D., 1963, Ground-water levels in observation wells in Kansas, 1962: Kansas Geological Survey Bulletin 167, 89 p.

*__ 1964, Ground-water levels in observation wells in Kansas, 1963: Kansas Geological Survey Bulletin 173, 93 p.

1965, Ground-water levels in observation wells in Kansas, 1964: Kansas Geological Survey Bulletin 177, 93 p.

1966, Ground-water levels in observation wells in Kansas, 1965: Kansas Geological Survey Bulletin 184, $91 \mathrm{p}$.

Brown, D.E., Meyer, M.T., Pomes, M.L., Thurman, E.M., and Goolsby, D.A., 1990, Temporal variations of triazine and chloroacetanilide herbicide concentrations in selected streams in the midwestern United States, in Abstracts for the AGU Fall Meeting, December 3-7, 1990, San Francisco, Calif.: EOS,
Transactions of the American Geophysical Union, v. 71, no. 43, October 23, 1990, p. 1331.

Buddemeier, R.W., Shamsnia, Saeed, Woods, John, and McClain, T.J., 1991, January 1990, Kansas water levels and data related to water-level changes: Kansas Geological Survey Open-File Report 91-12, 129 p.

Burnett, R.D., 1984, Predictive simulations of alternatives for managing the water resources of North Fork Solomon River Valley between Kirwin Dam and Waconda Lake, north-central Kansas: U.S. Geological Survey Water-Resources Investigations Report 84-4249, 34 p.

Burnett, R.D., and Reed, T.B., 1985, Simulation of the effects of management alternatives of the streamaquifer system, South Fork Solomon River Valley between Webster Reservoir and Waconda Lake, northcentral Kansas: U.S. Geological Survey WaterResources Investigations Report 85-4200, 19 p.

1986, Availability of water for irrigation in the South Fork Solomon River Valley, Webster Reservoir to Waconda Lake, north-central Kansas: U.S. Geological Survey Water-Resources Investigations Report 86-4064, 89 p.

Burns, C.V., 1967, Kansas streamflow characteristics, part 7, Annual streamflow summary tables: Kansas Water Resources Board Technical Report No. 7, 18 p.

1971, Kansas streamflow characteristics, part 8 , In-channel hydraulic geometry of streams in Kansas: Kansas Water Resources Board Technical Report No. $8,31 \mathrm{p}$.

1975, Kansas streamflow characteristics, temperatures of Kansas streams: Kansas Water Resources Board Technical Report No. 12, 220 p.

Burns, C.V., Maddy, D.V., Jordan, P.R., and McNellis, J.M., 1976, Kansas streamflow characteristics, physical and climatic characteristics along Kansas streams: Kansas Water Resources Board Technical Report No. 13,41 p.

*Busby, M.W., 1963, Yearly variations in runoff for the conterminous United States, 1931-60: U.S. Geological Survey Water-Supply Paper 1669-S, p. S1-S49.

* _ 1964, Relation of annual runoff to meteorological factors, in Geological Survey Research, 1964, Chapter C: U.S. Geological Survey Professional Paper 501-C, p. C188-C189.

1966, Annual runoff in the conterminous United States: U.S. Geological Survey Hydrologic Investigations Atlas HA-212, 1 sheet, scale 1:7,500,000.

Busby, M.W., and Armentrout, G.W., 1965, Kansas streamflow characteristics, part 6A, Base-flow data: Kansas Water Resources Board Technical Report No. 6A, $207 \mathrm{p}$. 
*Byrne, F.E., and McLaughlin, T.G., 1948, Geology and ground-water resources of Seward County, Kansas: Kansas Geological Survey Bulletin 69, 140 p.

Carr, J.E., McGovern, H.E., and Gogel, Tony, 1986, Geohydrology of and potential for fluid disposal in the Arbuckle aquifer in Kansas, with a section on Log analysis of the Arbuckle aquifer, by J.H. Doveton: U.S. Geological Survey Open-File Report 86-491, $101 \mathrm{p}$.

Carswell, W.J., Jr., 1978a, Description of data-collection system and synopsis of selected hydrologic data for Soldier Creek Basin, Kansas: U.S. Geological Survey Open-File Report 78-678, 80 p.

1978b, Hydrologic data for Soldier Creek Basin, Kansas: U.S. Geological Survey Water-Resources Investigations Report 78-87, $26 \mathrm{p}$.

1979, Multiyear low flow in southeastern Kansas: U.S. Geological Survey Water-Resources Investigations, Open-File Report 79-1288, 26 p.

1981, Selected hydrologic relations for Soldier Creek, northeastern Kansas: U.S. Geological Survey WaterResources Investigations Report 81-8, 68 p.

1982, Storage requirements to sustain gross reservoir outflow from small basins in Kansas: Kansas Water Office Technical Report No. 16, 40 p.

Carswell, W.J., Jr., and Bond, S.V., 1980, Multiyear low flow of streams in northeastern Kansas: U.S. Geological Survey Water-Resources Investigations, Open-File Report 80-734, 26 p.

Carswell, W.J., Jr., and Hart, R.J., 1985, Transit losses and travel times during drought conditions along the Neosho River from Council Grove Lake to Iola, eastcentral Kansas: U.S. Geological Survey WaterResources Investigations Report 85-4003, 40 p.

*Clarke, F.W., 1924, The composition of the river and lake waters of the United States: U.S. Geological Survey Professional Paper 135, $133 \mathrm{p}$.

Clement, R.W., 1983, Improvement of flood-frequency estimates for selected small watersheds in eastern Kansas using a rainfall-runoff model: U.S. Geological Survey Water-Resources Investigations Report 83-4110, 22 p.

1987, Floods in Kansas and techniques for estimating their magnitude and frequency on unregulated streams: U.S. Geological Survey Water-Resources Investigations Report 87-4008, 50 p.

1991, Kansas floods and droughts, in Paulson, R.W., Chase, E.B., Roberts, R.S., and Moody, D.W., compilers, National water summary 1988-89-Hydrologic events and floods and droughts: U.S. Geological Survey Water-Supply Paper 2375, p. 287-294.

Clement, R.W., and Johnson, D.G., 1982, Flood of June 15, 1981, in Great Bend and vicinity, central
Kansas: U.S. Geological Survey Water-Resources Investigations Report 82-4123, 12 p.

Collins, D.L., 1965, A general classification of source areas of fluvial sediment in Kansas: Kansas Water Resources Board Bulletin No. 8, 21 p.

Combs, L.J., compiler, 1984, Water-resources reports prepared by or in cooperation with the U.S. Geological Survey in Kansas, 1886-1983: U.S. Geological Survey Open-File Report 84-609, 117 p.

1985, Water-resources activities of the U.S. Geological Survey in Kansas-Fiscal years 1983 and 1984: U.S. Geological Survey Open-File Report 85-178, $97 \mathrm{p}$.

1987, Water-resources activities of the U.S. Geological Survey in Kansas-Fiscal years 1985 and 1986: U.S. Geological Survey Open-File Report 87-211, $108 \mathrm{p}$.

1989, Water-resources activities of the U.S. Geological Survey in Kansas-Fiscal years 1987 and 1988: U.S. Geological Survey Open-File Report 89-592, $97 \mathrm{p}$.

Combs, L.J., Hansen, C.V., and Wolf, R.J., 1993, Geohydrologic systems in Kansas-Geohydrology of the lower aquifer unit in the Western Interior Plains aquifer system: U.S. Geological Survey Hydrologic Investigations Atlas HA-722-I, 3 sheets, scale $1: 1,500,000$.

Combs, L.J., and Huntzinger, T.L., 1988, U.S. Geological Survey ground-water studies in Kansas: U.S. Geological Survey Open-File Report 88-160 (Water Fact Sheet), 2 p.

Combs, L.J., and Powell, K.A., compilers, 1992, Waterresources activities of the U.S. Geological Survey in Kansas-Fiscal years 1989, 1990, and 1991: U.S. Geological Survey Open-File Report 92-90, 130 p.

Cromwell, A.E., and Thurman, E.M., 1993a, Atrazine transport and degradation in a pristine watershed-The fate of atrazine deposited by precipitation, in Morganwalp, D.W., and Aronson, D.A., compilers, U.S. Geological Survey Toxic Substances Hydrology Program-Abstracts of the Technical Meeting, Colorado Springs, Colo., September 20-24, 1993: U.S. Geological Survey Open-File Report 93-454, p. 82.

1993b, Herbicide transport and degradation in a pristine watershed--The fate of herbicides deposited by precipitation [abs.], in Programs and proceedings of symposium on agricultural nonpoint sources of contaminants-Focus on herbicides, Lawrence, Kans., September 28-29, 1993: U.S. Environmental Protection Agency, Region VII, and U.S. Geological Survey, p. 17. 
Culbertson, D.M., 1963, Coordinated water-quality investigations in Kansas: 130th Meeting, Missouri Basin Inter-Agency Commission, 12 p.

Dabiri, H.E., Green, D.W., and Winslow, J.D., 1970, Digital computer simulation of an aquifer, in Proceedings of Summer Computer Simulation Conference, Denver, Colo., June 10-12, 1970, p. 944-954.

Dague, B.J., 1985a, January 1985 water levels, and data related to water-level changes in western and southcentral Kansas: U.S. Geological Survey Open-File Report 85-423, 162 p.

1985b, Percentage change in saturated thickness of the High Plains aquifer, west-central Kansas, 1950 to average 1983-85: U.S. Geological Survey WaterResources Investigations Report 85-4255, 1 sheet, scale 1:125,000.

1986a, January 1986 water levels, and data related to water-level changes, western and south-central Kansas: U.S. Geological Survey Open-File Report 86-317, $165 \mathrm{p}$.

1986b, Percentage change in saturated thickness of the High Plains aquifer, west-central Kansas, 1950 to average 1984-86: U.S. Geological Survey WaterResources Investigations Report 86-4365, 1 sheet, scale 1:125,000.

1987a, January 1987 water levels, and data related to water-level changes, western and south-central Kansas: U.S. Geological Survey Open-File Report 87-241, $161 \mathrm{p}$.

$1987 \mathrm{~b}$, Percentage change in saturated thickness of the High Plains aquifer, west-central Kansas, 1950 to average 1985-87: U.S. Geological Survey WaterResources Investigations Report 87-4252, 1 sheet, scale 1:125,000.

Dague, B.J., and Stullken, L.E., 1986, Kansas groundwater observation-well network, 1985: U.S. Geological Survey Open-File Report 86-231, 51 p.

Dankwardt, Andrea, Hock, Bertold, and Thurman, E.M., 1993, Comparison of enzyme-linked immunosorbent assay and gas chromatography/mass spectrometry for the analysis of atrazine in rainwater of Germany [abs.], in New separation and detection methods, Programme and Organisation Abstracts, New Swiss Chemical Society, Basel Switzerland, October 19-20, 1993: New Swiss Chemical Society, $2 \mathrm{p}$.

*Darton, N.H., 1905a, Preliminary list of deep borings in the United States: U.S. Geological Survey WaterSupply Paper 149, $175 \mathrm{p}$.

*__ 1905b, Preliminary report on the geology and underground water resources of the central Great Plains: U.S. Geological Survey Professional Paper 32, 433 p.
* __ 1920, Description of the Syracuse and Lakin quadrangles, Kansas: U.S. Geological Survey Geologic Atlas, Folio 212, 10 p., 6 pls., 7 figs.

*Davis, A.P., 1897, Report of progress of stream measurements for the calendar year 1896: U.S. Geological Survey 18th Annual Report, Part IV, p. 1-418.

*Davis, S.N., and Carlson, W.A., 1952, Geology and ground-water resources of the Kansas River Valley between Lawrence and Topeka, Kansas: Kansas Geological Survey Bulletin 96, pt. 5, p. 201-276.

Dealy, M.T., Kume, Jack, and Jenkins, E.D., 1984, Hydrogeology and development of the Dakota aquifer in southwest Kansas, in Jorgensen, D.G., and Signor, D.C., eds., Geohydrology of the Dakota aquifer: National Water Well Association, Proceedings of the First C.V. Theis Conference on Geohydrology, Lincoln, Nebr., October 5-6, 1982, p. 209-220.

Denne, J.E., 1979, Uncovering buried valleys in northeastern Kansas: Kansas Geological Survey, The Journal, v. 1, no. 3, 4 p.

Diaz, A.M., 1962a, Chemical quality program in Kansas: Kansas Water News, v. 5, no. 3, p. 3-5.

$1962 \mathrm{~b}$, Quality of water investigation in the Walnut River Basin: Kansas Water News, v. 5, no. 3, p. 6-7.

1965, Cooperative water-quality investigation, South Fork Ninnescah Basin: Kansas Water News, v. 8, no. 3, p. 3-4.

Dingman, R.J., 1969, Evaluation of the effects of the U.S. Bureau of Reclamation ring dike on the ground-water flow and water quality in the Downs area, Kansas: U.S. Geological Survey Open-File Report, 19 p.

Dingman, R.J., and Angino, E.E., 1969, Chemical composition of selected Kansas brines as an aid to interpreting change in water chemistry with depth: Chemical Geology, Amsterdam, v. 4, p. 325-339.

Dufford, A.E., 1958, Quaternary geology and ground-water resources of the Kansas River Valley between Bonner Springs and Lawrence, Kansas: Kansas Geological Survey Bulletin 130, pt. 1, 96 p.

Dugan, J.T., 1986, Hydrologic characteristics of soils in parts of Arkansas, Colorado, Kansas, Missouri, Nebraska, New Mexico, Oklahoma, South Dakota, and Texas: U.S. Geological Survey Hydrologic Investigations Atlas HA-678, 1 sheet, scale 1:1,500,000.

Dugan, J.T., Schild, D.E., and Kastner, W.M., 1990, Water-level changes in the High Plains aquifer underlying parts of South Dakota, Wyoming, Nebraska, Colorado, Kansas, New Mexico, Oklahoma, and Texas-Predevelopment through nonirrigation season 1988-89: U.S. Geological Survey WaterResources Investigations Report 90-4153, 29 p. 
Dunlap, L.E., 1980, Simulated water-level declines near Marienthal, west-central Kansas: U.S. Geological Survey Water-Resources Investigations Report 80-39, $15 \mathrm{p}$.

1982, Geohydrology of principal aquifers in the Republican River Basin, Kansas: U.S. Geological Survey Open-File Report 82-79, 5 sheets, scale 1:250,000.

Dunlap, L.E., Kume, Jack, and Thomas, J.G., 1980, Geohydrology and model analysis for water-supply management in a small area of west-central Kansas: U.S. Geological Survey Water-Resources Investigations Report 80-91, $59 \mathrm{p}$.

Dunlap, L.E., Lindgren, R.J., and Carr, J.E., 1984, Projected effects of ground-water withdrawals in the Arkansas River Valley, 1980-99, Hamilton and Kearny Counties, southwestern Kansas: U.S. Geological Survey Water-Resources Investigations Report 84-4082, 168 p.

Dunlap, L.E., Lindgren, R.J., and Sauer, C.G., 1983, Geohydrology and model analysis of stream-aquifer system along the Arkansas River in Kearny and Finney Counties, southwestern Kansas: U.S. Geological Survey Open-File Report 83-222, 84 p.

1985, Geohydrology and model analysis of streamaquifer system along the Arkansas River in Kearny and Finney Counties, southwestern Kansas: U.S. Geological Survey Water-Supply Paper 2253, 52 p.

Dunlap, L.E., and Spinazola, J.M., 1981, Hydrologic maps of Ogallala aquifer, west-central Kansas, 1978-80: U.S. Geological Survey Open-File Report 81-908, 4 sheets, scale 1:125,000.

1984, Interpolating water-table altitudes in westcentral Kansas using kriging techniques: U.S. Geological Survey Water-Supply Paper 2238, 19 p.

Durum, W.H., 1951, Chemical quality of the surface waters in the Saline River Basin, Kansas, a progress report: U.S. Geological Survey Open-File Report, 54 p. 1953, Relationship of the mineral constituents in solution to streamflow, Saline River near Russell, Kansas: Transactions of the American Geophysical Union, v. 34, no. 3, p. 435-442.

Ehlig, Christine, and Halepaska, J.C., 1976, A numerical study of confined-unconfined aquifers including effects of delayed yield and leakage: American Geophysical Union, Water Resources Research, v. 12, no. 6, p. 1175-1183.

Ellis, D.W., and Edelen, G.W., Jr., 1960, Kansas streamflow characteristics, part 3, Flood frequency: Kansas Water Resources Board Technical Report No. 3, 221 p.

Ellis, D.W., and others, 1963, Floods at Wichita, Kansas: U.S. Geological Survey Hydrologic Investigations Atlas HA-63, 5 sheets, scale 1:24,000.
Fader, S.W., 1967, Notes on the shape of the truncated cone of depression in the vicinity of an infinite well field: Kansas Geological Survey Special Distribution Publication 33, $10 \mathrm{p}$.

1968, Ground water in the Republican River area, Cloud, Jewell, and Republic Counties, Kansas: Kansas Geological Survey Bulletin 188, 27 p.

1974, Ground water in the Kansas River Valley, Junction City to Kansas City, Kansas: Kansas Geological Survey Bulletin 206, pt. 2, 12 p.

1975, Land subsidence caused by dissolution of salt near four oil and gas wells in central Kansas: U.S. Geological Survey Water-Resources Investigations Report 27-75, $28 \mathrm{p}$.

Fader, S.W., Gutentag, E.D., Lobmeyer, D.H., and Meyer, W.R., 1964, Geohydrology of Grant and Stanton Counties, Kansas: Kansas Geological Survey Bulletin 168, $147 \mathrm{p}$.

Fader, S.W., and Morton, R.B., 1975a, Ground water in the Middle Arkansas River Basin, Kansas and Oklahoma: U.S. Geological Survey Open-File Report 75-367, 44 p.

1975b, Ground water in the Verdigris River Basin, Kansas and Oklahoma: U.S. Geological Survey OpenFile Report 75-365, 26 p.

Fader, S.W., and Stullken, L.E., 1976, Geohydrologic maps of the Great Bend Prairie, south-central Kansas: U.S. Geological Survey Open-File Report 76-405, 4 sheets, scale $1: 250,000$.

1977, Geohydrology of the Great Bend Prairie, southcentral Kansas: U.S. Geological Survey Open-File Report 77-305, $53 \mathrm{p}$.

1978, Geohydrology of the Great Bend Prairie, southcentral Kansas: Kansas Geological Survey Irrigation Series $4,19 \mathrm{p}$.

Fallon, J.D., 1994, Determining the 3-dimensional distribution, transport, and relative age of atrazine and selected metabolites in Perry Lake, Kansas: Lawrence, University of Kansas, master's thesis, $176 \mathrm{p}$.

Fallon, J.D., and McChesney, J.A., 1993, Surface-waterquality assessment of the lower Kansas River Basin, Kansas and Nebraska—Project data, November 1986 through April 1990: U.S. Geological Survey OpenFile Report 93-51, 594 p.

Fallon, J.D., and Thurman, E.M., 1993a, Determining the age, transport, and three-dimensional distribution of atrazine in a reservoir by immunoassay [abs.], in Programs and proceedings of symposium on agricultural nonpoint sources of contaminants-Focus on herbicides, Lawrence, Kans., September 28-29, 1993 : U.S. Environmental Protection Agency, Region VII, and U.S. Geological Survey, p. 13. 
$1993 \mathrm{~b}$, Determining the relative age, transport, and three-dimensional distribution of atrazine in a reservoir using immunoassay [abs.], in Morganwalp, D.W., and Aronson, D.A., compilers, U.S. Geological Survey Toxic Substances Hydrology Program-Abstracts of the Technical Meeting, Colorado Springs, Colo., September 20-24, 1993: U.S. Geological Survey Open-File Report 93-454, p. 72.

Falwell, Ronald, Bigsby, P.R., and Myers, N.C., 1990, Hydrogeology and ground-water-quality conditions at the Linn County Landfill, eastern Kansas, 1988-89: U.S. Geological Survey Water-Resources Investigations Report 90-4117, 48 p.

Fan, Jian, Wolock, D.M., and Lawrence, Gregory, 1994, Using GIS to study the spatial relation between watershed topography and stream chemistry in the Neversink River Basin, New York [abs.]: EOS, Transactions of the American Geophysical Union, v. 75 , no. 16 , unnumbered page.

Feder, G.L., and Krothe, N.C., 1981, Results of a reconnaissance water-quality sampling program of the Ogallala aquifer in Colorado, Kansas, Nebraska, Oklahoma, South Dakota, and Texas: U.S. Geological Survey Water-Resources Investigations Report 81-65, $7 \mathrm{p}$.

*Fent, O.S., 1950, Geology and ground-water resources of Rice County, Kansas: Kansas Geological Survey Bulletin 85, 142 p.

Fishel, V.C., 1947a, Ground-water resources of Kansas: Transactions of the Kansas Academy of Science, v. 50, no. 2, p. 105-114.

$1947 \mathrm{~b}$, Methods used in ground-water investigations in Kansas: Geological Society of America Bulletin, v. 58 , no. 12 , pt. 2, p. 1273.

*___ 1948a, Geology and ground-water resources of Republic County and northern Cloud County, Kansas: Kansas Geological Survey Bulletin 73, 194 p.

*__ 1948b, Ground-water resources of the Kansas City, Kansas, area: Kansas Geological Survey Bulletin 71, $109 \mathrm{p}$.

*__ 1952a, Ground-water resources of Pawnee Valley, Kansas: Kansas Geological Survey Bulletin 94, 144 p.

1952b, Kansas-Missouri floods of July 1, 1951, with a section on Fluctuations of ground water levels, by V.C. Fishel: U.S. Geological Survey Water-Supply Paper 1139, $239 \mathrm{p}$.

1956, Long-term trends of ground-water levels in the United States: Transactions of the American Geophysical Union, v. 37, no. 4, p. 429-435.

*__ 1963, Kansas, in McGuinness, C.L., The role of ground water in the national water situation: U.S. Geological Survey Water-Supply Paper 1800, 1121 p.
*Fishel, V.C., and Broeker, M.E., 1960, Ground-water levels in observation wells in Kansas, 1959: Kansas Geological Survey Bulletin 146, 174 p.

*Fishel, V.C., Gulley, E.L., and Reavis, E.L., 1959, Ground-water levels in observation wells in Kansas, 1958: Kansas Geological Survey Bulletin 141, 146 p.

Fishel, V.C., and Leonard, A.R., 1955, Geology and ground-water resources of Jewell County, Kansas: Kansas Geological Survey Bulletin 115, 152 p.

*Fishel, V.C., and Mason, B.J., 1957, Ground-water levels in observation wells in Kansas, 1956: Kansas Geological Survey Bulletin 125, 158 p.

*__ 1958, Ground-water levels in observation wells in Kansas, 1957: Kansas Geological Survey Bulletin 131, $152 \mathrm{p}$.

*Fishel, V.C., Searcy, J.K., and Rainwater, F.H., 1953, Water resources of the Kansas City area, Missouri and Kansas: U.S. Geological Survey Circular 273, 52 p.

*Follansbee, Robert, and Spiegel, J.B., 1937, Flood on Republican and Kansas Rivers, May and June 1935: U.S. Geological Survey Water-Supply Paper 796-B, p. 21-52.

*Frye, J.C., 1940, A preliminary report on the water supply of the Meade Artesian Basin, Meade County, Kansas: Kansas Geological Survey Bulletin 35, 39 p.

*__ 1941, Reconnaissance of ground-water resources of Atchison County, Kansas: Kansas Geological Survey Bulletin 38, pt. 9, p. 237-260.

*__ 1942, Geology and ground-water resources of Meade County, Kansas: Kansas Geological Survey Bulletin 45, $152 \mathrm{p}$.

* _ 1945, Geology and ground-water resources of Thomas County, Kansas: Kansas Geological Survey Bulletin 59, $110 \mathrm{p}$.

*Frye, J.C., Brazil, J.J., and Stoltenberg, H.A., 1943, Ground-water in the oil-field areas of Ellis and Russell Counties, Kansas: Kansas Geological Survey Bulletin 50, $104 \mathrm{p}$.

*Frye, J.C., and Fishel, V.C., 1949, Ground water in southwestern Kansas: Kansas Geological Survey Miscellaneous Publication, $24 \mathrm{p}$.

*Frye, J.C., and Leonard, A.R., 1949, Geology and ground-water resources of Norton County and northwestern Phillips County, Kansas: Kansas Geological Survey Bulletin 81, $144 \mathrm{p}$.

*Frye, J.C., and Walters, K.L., 1950, Subsurface reconnaissance of glacial deposits in northeastern Kansas: Kansas Geological Survey Bulletin 86, pt. 6, p. 141-158.

Furness, L.W., 1957, Development of a balanced streamgaging program for Kansas: Kansas Water Resources Board Bulletin No. 4, $50 \mathrm{p}$. 
1959, Kansas streamflow characteristics, part 1, Flow duration: Kansas Water Resources Board Technical Report No. 1, 213 p.

1960, Kansas streamflow characteristics, part 2, Lowflow frequency: Kansas Water Resources Board Technical Report No. 2, 179 p.

1962, Kansas streamflow characteristics, part 4 Storage requirements to sustain gross reservoir outflow: Kansas Water Resources Board Technical Report No. 4, 177 p.

1965a, Discussion of areal variations of mean annual runoff: American Society Civil Engineers Proceedings 4304, May, p. 336-341.

$1965 \mathrm{~b}$, Small area flood volume study, Rock Creek Basin, Meriden, Kansas-Progress report, July 1963 to Feb. 1965: U.S. Geological Survey Open-File Report, $42 \mathrm{p}$.

Furness, L.W., Burns, C.V., and Busby, M.W., 1964, Kansas streamflow characteristics, part 5, Storage requirements to control high flow: Kansas Water Resources Board Technical Report No. 5, 169 p.

1966, Kansas streamflow characteristics, part 6B, Base flow distribution: Kansas Water Resources Board Technical Report No. 6B, 139 p.

*Furness, L.W., and Busby, M.W., 1967, Two methods of estimating base flow at ungaged stream sites in Kansas and adjacent states, in Geological Survey Research, 1967, Chapter C: U.S. Geological Survey Professional Paper 575-C, p. C208-C211.

*Gannett, Henry, 1898, A gazetteer of Kansas: U.S. Geological Survey Bulletin 154, 246 p.

Geiger, C.O., Lacock, D.L., Putnam, J.E., Merry, C.E., and Schneider, D.R., 1987, Water resources data, Kansas, water year 1986: U.S. Geological Survey Water Data Report KS-86-1, 482 p.

1988, Water resources data, Kansas, water year 1987: U.S. Geological Survey Water Data Report KS-87-1, $492 \mathrm{p}$.

Geiger, C.O., Lacock, D.L., Putnam, J.E., Riche, B.L., and Merry, C.E., 1986, Water resources data, Kansas, water year 1985: U.S. Geological Survey Water-Data Report KS-85-1, 478 p

Geiger, C.O., Lacock, D.L., Schneider, D.R., Carlson, M.D., and Dague, B.J., 1993, Water resources data Kansas, water year 1992: U.S. Geological Survey Water-Data Report KS-92-1, 500 p.

1994, Water resources data Kansas, water year 1993 : U.S. Geological Survey Water-Data Report KS-93-1, 497 p.
Geiger, C.O., Lacock, D.L., Schneider, D.R., Carlson, M.D., and Merry, C.E., 1989, Water resources data, Kansas, water year 1988: U.S. Geological Survey Water-Data Report KS-88-1, 490 p.

1990, Water resources data, Kansas, water year 1989: U.S. Geological Survey Water-Data Report KS-89-1, $457 \mathrm{p}$.

Geiger, C.O., Lacock, D.L., Schneider, D.R., Carlson, M.D., and Pabst, B.J., 1991, Water resources data, Kansas, water year 1990: U.S. Geological Survey Water-Data Report KS-90-1, 370 p.

1992, Water resources data, Kansas, water year 1991: U.S. Geological Survey Water-Data Report KS-91-1, $358 \mathrm{p}$.

Geiger, C.O., Lacock, D.L., Shelton, L.R., Penny, M.L., and Merry, C.E., 1983, Water resources data, Kansas, water year 1982: U.S. Geological Survey Water-Data Report KS-82-1, 485 p.

1984, Water resources data, Kansas, water year 1983: U.S. Geological Survey Water-Data Report KS-83-1, 483 p.

1985, Water resources data, Kansas, water year 1984: U.S. Geological Survey Water-Data Report KS-84-1, $500 \mathrm{p}$.

Gillespie, J.B., Green, D.W., and Slagle, S.E., 1970, Artificial ground-water recharge, Wet Walnut Creek, central Kansas-Progress report number two: Kansas Water Resources Board, $28 \mathrm{p}$.

Gillespie, J.B., and Hargadine, G.D., 1975, Results of infiltration tests near Scott City, western Kansas: U.S. Geological Survey Water-Resources Investigations Report 76-12, 29 p.

1981, Saline ground-water discharge to the Smoky Hill River between Salina and Abilene, central Kansas: U.S. Geological Survey Water-Resources Investigations Report 81-43, $71 \mathrm{p}$

1986, Geohydrology of the Wellington-alluvial aquifer system and evaluation of possible locations of relief wells to decrease saline ground-water discharge to the Smoky Hill and Solomon Rivers, central Kansas: U.S. Geological Survey Water-Resources Investigations Report 86-4110, 31 p.

1994, Geohydrology and saline ground-water discharge to the South Fork Ninnescah River in Pratt and Kingman Counties, south-central Kansas: U.S. Geological Survey Water-Resources Investigations Report 93-4177, 51 p.

Gillespie, J.B., Hargadine, G.D., Myers, N.C., and Hargadine, D.A., 1991, Geohydrologic data for the South Fork Ninnescah River Valley and adjacent plains in Pratt and Kingman Counties, south-central Kansas: U.S. Geological Survey Open-File Report 91-186, $55 \mathrm{p}$. 
Gillespie, J.B., Hargadine, G.D., and Stough, M.J., 1977, Artificial-recharge experiments near Lakin, western Kansas: Kansas Water Resources Board Bulletin No. 20, 91 p.

Gillespie, J.B., Lindskov, K.L., and Slagle, S.E., 1969, Artificial ground-water recharge, Wet Walnut Creek-Progress report number one: Kansas Water Resources Board, $22 \mathrm{p}$.

Gillespie, J.B., and Perry, C.A., 1988, Channel infiltration from floodflows along the Pawnee River and its tributaries, west-central Kansas: U.S. Geological Survey Water-Resources Investigations Report 88-4055, $30 \mathrm{p}$.

Gillespie, J.B., and Slagle, S.E., 1972, Natural and artificial ground-water recharge, Wet Walnut Creek, central Kansas: Kansas Water Resources Board Bulletin No. 17, 94 p.

Gogel, Tony, 1981a, Discharge of saltwater from Permian rocks to major stream-aquifer systems in central Kansas: Kansas Geological Survey Chemical Quality Series $9,60 \mathrm{p}$.

1981b, Preliminary data from Arbuckle test wells, Miami, Douglas, Saline, and Labette Counties, Kansas: U.S. Geological Survey Open-File Report 81-1112, $155 \mathrm{p}$.

Goolsby, D.A., and Thurman, E.M., 1990, Pesticides in streams in the upper midwestern United States: Proceedings of 7 th Annual Water and the Future of Kansas Conference, Manhattan, Kans., March 7-8, 1990, p. 27-28.

Goolsby, D.A., Thurman, E.M., Clark, M.L., and Pomes, M.L., 1990, Immunoassay as a screening tool for triazine herbicides in streams-Comparison with gas chromatographic/mass spectrometric methods, in Vanderlaan, Martin, Stanker, L.H., Watkins, B.E., and Roberts, D.W., eds., Immunoassays for trace chemical analysis: American Chemical Society Symposium Series 451 , chap. 8, p. 86-99.

Goolsby, D.A., Thurman, E.M., and Kolpin, D.W., 1990, Geographic and temporal distribution of herbicides in surface waters of the upper midwestern United States, 1989-90: U.S. Geological Survey Water-Resources Investigations Report 91-4034, p. 183-188.

1991, Herbicides in streams--Midwestern United States: Irrigation and Drainage, Proceedings of 1991 National Conference, American Society of Civil Engineers, July 22-26, 1991, Honolulu, Hawaii, p. 17-23.

Gutentag, E.D., 1975, Map showing percent change in saturated thickness of unconsolidated aquifer, 1950-76, west-central Kansas: U.S. Geological Survey Open-File Report 76-457, 1 sheet, scale $1: 125,000$.
Gutentag, E.D., and Galli-Olivier, Carlos, 1969, New locations of Pleistocene (Kansan) molluscan and ostracode faunas, Dickinson County, Kansas, in Geological Survey Research: U.S. Geological Survey Professional Paper 650-D, p. D148-D154.

Gutentag, E.D., Heimes, F.J., Krothe, N.C., Luckey, R.R., and Weeks, J.B., 1984, Geohydrology of the High Plains aquifer in parts of Colorado, Kansas, Nebraska, New Mexico, Oklahoma, South Dakota, Texas, and Wyoming: U.S. Geological Survey Professional Paper 1400-B, 63 p.

Gutentag, E.D., Lobmeyer, D.H., and McGovern, H.E., 1970, Ground water in Kearny County, southwestern Kansas: U.S. Geological Survey Open-File Report, $40 \mathrm{p}$.

1972, Ground water in Kearny County, southwestern Kansas: U.S. Geological Survey Hydrologic Investigations Atlas HA-416, 2 sheets, scale 1:125,000.

Gutentag, E.D., Lobmeyer, D.H., McGovern, H.E., and Long, W.A., 1972, Ground water in Finney County, southwestern Kansas: U.S. Geological Survey Hydrologic Investigations Atlas HA-442, 3 sheets, scale 1:250,000.

Gutentag, E.D., Lobmeyer, D.H., and Slagle, S.E., 1978, Map showing saturated thickness of the unconsolidated aquifer, southwestern Kansas, January 1975: U.S. Geological Survey Open-File Report 78-80, 1 sheet, scale 1:250,000.

1980, Geohydrology of southwestern Kansas: U.S. Geological Survey Open-File Report 80-218, 97 p.

1981, Geohydrology of southwestern Kansas: Kansas Geological Survey Irrigation Series 7,73 p.

Gutentag, E.D., and Stullken, L.E., 1974, Ground water in Haskell County, southwestern Kansas: U.S. Geological Survey Hydrologic Investigations Atlas HA-515, 2 sheets, scale 1:250,000.

1976, Ground-water resources of Lane and Scott Counties, western Kansas: Kansas Geological Survey Irrigation Series 1, $37 \mathrm{p}$.

Halepaska, J.C., and Hartman, J.W., 1972, Numerical solution of the three-dimensional heat flow equation: Kansas Geological Survey Bulletin 204, pt. 1, p. 11-13.

Hansen, C.V., 1991a, Description and evaluation of selected methods used to delineate wellhead-protection areas around public-supply wells near Mt. Hope, Kansas: U.S. Geological Survey Water-Resources Investigations Report 90-4102, 39 p.

1991b, Estimates of freshwater storage and potential natural recharge for principal aquifers in Kansas: U.S. Geological Survey Water-Resources Investigations Report 87-4230, $100 \mathrm{p}$. 
1993a, Description of geographic-informationsystem files containing water-resource-related data compiled and collected for Wyandotte County, northeastern Kansas: U.S. Geological Survey Open-File Report 93-92, 46 p.

1993b, Description of water-resource-related data compiled for Harvey County, south-central Kansas: U.S. Geological Survey Open-File Report 93-116, $29 \mathrm{p}$.

1993c, Description of water-resource-related data compiled for Reno County, south-central Kansas: U.S. Geological Survey Open-File Report 93-99, 27 p.

Hansen, C.V., Spinazola, J.M., and Wolf, R.J., 1994, Geohydrologic systems in Kansas-Physical framework of the lower aquifer unit in the Western Plains aquifer system: U.S. Geological Survey Hydrologic Investigations Atlas 722-F, 2 sheets, scales $1: 1,000,000$ and 1:3,000,000.

Hansen, C.V., Underwood, E.J., Wolf, R.J., and Spinazola, J.M., 1992, Geohydrologic systems in Kansas-Physical framework of the upper aquifer unit of the Western Interior Plains aquifer system: U.S. Geological Survey Hydrologic Investigations Atlas HA-722-D, 2 sheets, scales 1:1,000,000 and $1: 3,000,000$

Hansen, C.V., Wolf, R.J., and Spinazola, J.M., 1992, Geohydrologic systems in Kansas-Physical framework of the confining unit in the Western Interior Plains aquifer system: U.S. Geological Survey Hydrologic Investigations Atlas HA-722-E, 2 sheets, scales $1: 1,000,000$ and 1:3,000,000.

Hart, R.J., and Spruill, T.B., 1988, Description and hydrologic evaluation of nine hazardous-waste sites in Kansas, 1984-86: U.S. Geological Survey WaterResources Investigations Report 88-4015, $73 \mathrm{p}$.

Hart, R.J., and Stiles, T.C., 1984, Availability of natural and regulated streamflows for instream uses during historical droughts, lower Neosho River, southeastern Kansas: U.S. Geological Survey Water-Resources Investigations Report 84-4292, 42 p.

Hathaway, L.R., Carr, B.L., Flanagan, M.A., Galle, O.K., Waugh, T.C., Dickey, H.P., and Magnuson, L.M., 1978, Chemical quality of irrigation waters in southwestern Kansas: Kansas Geological Survey Chemical Quality Series 6, 35 p.

Hathaway, L.R., Carr, B.L., Galle, O.K., Magnuson, L.M., Waugh, T.C., and Dickey, H.P., 1977, Chemical quality of irrigation waters in Hamilton, Kearny, Finney, and northern Gray Counties: Kansas Geological Survey Chemical Quality Series 4, 33 p.

Hathaway, L.R., Galle, O.K., Waugh, T.C., and Dickey, H.P., 1978, Chemical quality of irrigation waters in Ford County and the Great Bend Prairie of Kansas: Kansas Geological Survey Chemical Quality Series 7, $41 \mathrm{p}$.
Hathaway, L.R., Magnuson, L.M., Carr, B.L., Galle, O.K., and Waugh, T.C., 1975, Chemical quality of irrigation waters in west-central Kansas: Kansas Geological Survey Chemical Quality Series 2, 46 p.

Hathaway, L.R., Waugh, T.C., Galle, O.K., and Dickey, H.P., 1979, Chemical quality of irrigation waters in northwestern Kansas: Kansas Geological Survey Chemical Quality Series 8, $45 \mathrm{p}$.

1981, Chemical quality of irrigation waters in the Equus-beds area, south-central Kansas: Kansas Geological Survey Chemical Quality Series 10,45 p.

Hauth, L.D., and Carswell, W.J., Jr., 1978, Floods in Kansas City, Missouri and Kansas, September 12-13, 1977: U.S. Geological Survey Water-Resources Investigations Report 78-63, 43 p.

Hauth, L.D., Carswell, W.J., Jr., U.S. Geological Survey, and Chin, E.H., National Weather Service, National Oceanic and Atmospheric Administration, 1981, Floods in Kansas City, Missouri and Kansas, September 12-13, 1977: U.S. Geological Survey Professional Paper 1169, 47 p.

*Haworth, Erasmus, 1897, Underground waters of southwestern Kansas: U.S. Geological Survey Water-Supply Paper 6, $65 \mathrm{p}$.

${ }^{*}$ Hay, Robert, 1890, A geological reconnaissance in southwestern Kansas: U.S. Geological Survey Bulletin 57, 49 p.

*__ 1895, Water resources of a portion of the Great Plains: U.S. Geological Survey 16th Annual Report, Part II, p. 535-588.

Heck, B.A., Myers, N.C., and Hargadine, D.A., 1992, Hydrogeology and ground-water-quality conditions at the Reno County Landfill, south-central Kansas, 1990-91: U.S. Geological Survey Water-Resources Investigations Report 92-4169, 56 p.

Hedman, E.R., and Engel, G.B., 1989, Flow characteristics for selected streams in the Great Plains subregion of the Central Midwest aquifer system and selected adjacent areas-Kansas and Nebraska, and parts of Colorado, Iowa, Missouri, New Mexico, Oklahoma, South Dakota, Texas, and Wyoming: U.S. Geological Survey Hydrologic Investigations Atlas HA-708, 3 sheets, scale 1:1,000,000.

Hedman, E.R., and Kastner, W.M., 1972, Kansas streamflow characteristics, part 9, Mean annual runoff as related to channel geometry of selected streams in Kansas: Kansas Water Resources Board Technical Report No. 9, 25 p.

1974, Progress report on streamflow characteristics as related to channel geometry of streams in the Missouri River Basin: U.S. Geological Survey Open-File Report, 24 p. 
1977, Streamflow characteristics related to channel geometry in the Missouri River Basin: U.S. Geological Survey Journal of Research, v. 5, no. 3, p. 285-300.

Hedman, E.R., Kastner, W.M., and Hejl, H.R., 1974, Kansas streamflow characteristics, part 10, Selected streamflow characteristics as related to active-channel geometry of streams in Kansas: Kansas Water Resources Board Technical Report No. 10,21 p.

Hedman, E.R., and Osterkamp, W.R., 1982, Streamflow characteristics related to channel geometry of streams in western United States: U.S. Geological Survey Water-Supply Paper 2193, 17 p.

Hedman, E.R., Skelton, John, and Freiwald, D.A., 1987, Flow characteristics for selected springs and streams in the Ozark subregion, Arkansas, Kansas, Missouri, and Oklahoma: U.S. Geological Survey Hydrologic Investigations Atlas HA-688, 4 sheets, scale 1:750,000.

Heidari, Manoutchehr, 1982, Groundwater management options for the Pawnee Valley of south-central Kansas: Kansas Geological Survey Ground-Water Series 4, $56 \mathrm{p}$.

Heimes, F.J., and Luckey, R.R., 1980, Evaluating methods for determining water use in the High Plains in parts of Colorado, Kansas, Nebraska, New Mexico, Oklahoma, South Dakota, Texas, and Wyoming, 1979: U.S. Geological Survey Water-Resources Investigations Report 80-111, 118 p.

1983, Estimating 1980 ground-water pumpage for irrigation on the High Plains in parts of Colorado, Kansas, Nebraska, New Mexico, Oklahoma, South Dakota, Texas, and Wyoming: U.S. Geological Survey Water-Resources Investigations Report 83-4123, $36 \mathrm{p}$.

Hejl, H.R., Jr., 1977, A method for adjusting values of Manning's roughness coefficient for flooded urban areas: U.S. Geological Survey Journal of Research, v. 5 , no. 5 , p. 541-545.

Helgesen, J.O., 1990, Effects of agricultural and petroleum-production land use on water quality in the High Plains aquifer, south-central Kansas [abs.]: Ground Water, v. 28, no. 5, p. 795.

1991, Effects of land use on ground-water quality, south-central Kansas [abs.]: Proceedings of 8th Annual Water and the Future of Kansas-Water in Conflict, Manhattan, Kans., March 4-5, 1991, p. 40.

Helgesen, J.O., and Hansen, C.V., 1989, Description of data files compiled for the Central Midwest regional aquifer-system analysis: U.S. Geological Survey Open-File Report 89-42, 37 p.

Helgesen, J.O., Heck, B.A., and Hargadine, D.A., 1993, Hydrogeology and ground-water-quality conditions at the Harvey County Landfill, south-central Kansas, 1990: U.S. Geological Survey Water-Resources Investigations Report 93-4036, 44 p.
Helgesen, J.O., Jorgensen, D.G., Leonard, R.B., and Signor, D.C., 1982, Regional study of the Dakota aquifer (Darton's Dakota revisited): Ground Water, v. 20 , no. 4 , p. $410-414$.

Helgesen, J.O., and Leonard, R.B., 1988, Geohydrology of the Great Plains aquifer system, central United States, in Abstracts of Twenty-Fourth Annual Conference, Water Years Ahead-Quality and Quantity, 1990 and Beyond: American Water Resources Association, Milwaukee, Wisc., November 6-8, 1988, p. 49.

1989, Geohydrology of the Great Plains aquifer system, central United States, in Swain, L.A., and Johnson, A.I., eds., Regional aquifer systems of the United States-Aquifers of the midwestern area: American Water Resources Association, AWRA Monograph Series No. 13, p. 179-190.

Helgesen, J.O., Leonard, R.B., and Wolf, R.J., 1993, Hydrology of the Great Plains aquifer system in Nebraska, Colorado, Kansas, and adjacent areas: U.S. Geological Survey Professional Paper 1414-E, 80 p., 10 pls.

Helgesen, J.O., and Perry, C.A., 1990, Occurrence of pesticides in Kansas ground water [abs.]: Proceedings of 7 th Annual Water and the Future of Kansas Conference, Manhattan, Kans., March 7-8, 1990, p. 22.

Helgesen, J.O., and Rutledge, A.T., 1989, Relations between land use and water quality in the High Plains aquifer of south-central Kansas, in Mallard, G.E., and Aronson, D.A., eds., U.S. Geological Survey Toxic Substances Hydrology Program-Proceedings of the Technical Meeting, Phoenix, Ariz., September 26-30, 1988: U.S. Geological Survey Water-Resources Investigations Report 88-4220, p. 437-443.

Helgesen, J.O., Stullken, L.E., and Rutledge, A.T., 1991a, Overview of nonpoint-source contamination of the High Plains aquifer in south-central Kansas, in Mallard, G.E., and Aronson, D.A., compilers, Abstracts of the Technical Meeting, U.S. Geological Survey Toxic Substances Hydrology Program, Monterey, Calif., March 11-15, 1991: U.S. Geological Survey Open-File Report 91-88, p. 46.

1991b, Overview of nonpoint-source contamination of the High Plains aquifer in south-central Kansas, in Mallard, G.E., and Aronson, D.A., eds., U.S. Geological Survey Toxic Substances Hydrology Program-Proceedings of the Technical Meeting, Monterey, Calif., March 11-15, 1991: U.S.

Geological Survey Water-Resources Investigations Report 91-4034, p. 301-306. 
1994, Assessment of nonpoint-source contamination of the High Plains aquifer in south-central Kansas, 1987: U.S. Geological Survey Water-Supply Paper 2381-C, 51 p.

Helgesen, J.O., and Thurman, E.M., 1988, Trace organic compounds in ground water in south-central Kansas as inferred from gas chromatography with flame-ionization detection, in Preprints of papers presented at the 196th ACS National Meeting: American Chemical Society, Los Angeles, Calif., September 25-30, 1988, v. 28 , no. 2 , p. $9-12$.

*Hinds, Henry, and Greene, F.C., 1917, Description of the Leavenworth and Smithville quadrangles, MissouriKansas: U.S. Geological Survey Geologic Atlas, Folio 206, 13 p., 10 pls., 10 figs.

Hodson, W.G., 1959, Geology and ground-water resources of Mitchell County, Kansas: Kansas Geological Survey Bulletin 140, 132 p.

1963, Geology and ground-water resources of Wallace County, Kansas: Kansas Geological Survey Bulletin 161, 108 p.

1965, Geology and ground-water resources of Trego County, Kansas: Kansas Geological Survey Bulletin 174, 80 p.

1969, Geology and ground-water resources of Decatur County, Kansas: Kansas Geological Survey Bulletin 196, 41 p.

Hodson, W.G., and Wahl, K.D., 1960, Geology and ground-water resources of Gove County, Kansas: Kansas Geological Survey Bulletin 145, 126 p.

Huntzinger, T.L., 1985, Federal-State Cooperative Program in Kansas, seminar proceedings, July 1985: U.S. Geological Survey Open-File Report 85-641, 39 p.

1991, National water-quality assessment program-The Central Nebraska Basins: U.S. Geological Survey Open-File Report 91-97, 2 p.

Huntzinger, T.L., and Stullken, L.E., 1988, An experiment in representative ground-water sampling for water-quality analysis: U.S. Geological Survey WaterResources Investigations Report 88-4178, 12 p.

Imes, J.L., 1989a, Geohydrology and hydrochemistry of the Ozark Plateaus aquifer system, in Swain, L.A., and Johnson, A.I., eds., Regional aquifer systems of the United States, Aquifers of the midwestern area: American Water Resources Association Monograph Series 13 , p. $165-178$.

1989b, Major geohydrologic units in and adjacent to the Ozark Plateaus Province, Missouri, Arkansas, Kansas, and Oklahoma: U.S. Geological Survey Hydrologic Investigations Atlas HA-711-A, 1 sheet, scale 1:750,000.
$1989 \mathrm{c}$, Major geohydrologic units in and adjacent to the Ozark Plateaus Province, Missouri, Arkansas, Kansas, and Oklahoma-Basement confining unit: U.S. Geological Survey Hydrologic Investigations Atlas HA-711-B, 1 sheet, scale 1:750,000.

$1990 a$, Major geohydrologic units in and adjacent to the Ozark Plateaus Province, Missouri, Arkansas, Kansas, and Oklahoma-Ozark aquifer: U.S. Geological Survey Hydrologic Investigations Atlas HA-711-E, 3 sheets, scale 1:750,000.

$1990 \mathrm{~b}$, Major geohydrologic units in and adjacent to the Ozark Plateaus Province, Missouri, Arkansas, Kansas, and Oklahoma-Ozark confining unit: U.S. Geological Survey Hydrologic Investigations Atlas HA-711-F, 3 sheets, scale 1:750,000.

1990c, Major geohydrologic units in and adjacent to the Ozark Plateaus Province, Missouri, Arkansas, Kansas, and Oklahoma-Springfield Plateau aquifer: U.S. Geological Survey Hydrologic Investigations Atlas HA-711-G, 3 sheets, scale 1:750,000.

1990d, Major geohydrologic units in and adjacent to the Ozark Plateaus Province, Missouri, Arkansas, Kansas, and Oklahoma-St. Francois aquifer: U.S. Geological Survey Hydrologic Investigations Atlas HA-711-C, 2 sheets, scale 1:750,000.

1990e, Major geohydrologic units in and adjacent to the Ozark Plateaus Province, Missouri, Arkansas, Kansas, and Oklahoma-St. Francois confining layer: U.S. Geological Survey Hydrologic Investigations Atlas HA-711-D, 3 sheets, scale 1:750,000.

1990f, Major geohydrologic units in and adjacent to the Ozark Plateaus Province, Missouri, Arkansas, Kansas, and Oklahoma-Western Interior Plains confining system: U.S. Geological Survey Hydrologic Investigations Atlas $\mathrm{HA}-711-\mathrm{H}, 3$ sheets, scale $1: 750,000$.

Imes, J.L., and Davis, J.V., 1990a, Water type and concentration of dissolved solids, chloride, and sulfate in ground water from the Springfield Plateau aquifer in Missouri, Arkansas, Kansas, and Oklahoma: U.S. Geological Survey Hydrologic Investigations Atlas HA-711-L, 2 sheets, scale 1:750,000.

$1990 \mathrm{~b}$, Water type and concentration of dissolved solids, chloride, and sulfate in water from the St. Francois aquifer in Missouri, Arkansas, Kansas, and Oklahoma: U.S. Geological Survey Hydrologic Investigations Atlas $\mathrm{HA}-711-\mathrm{J}, 1$ sheet, scale $1: 750,000$.

1991, Water type and concentration of dissolved solids, chloride, and sulfate in ground water from the Ozark aquifer in Missouri, Arkansas, Kansas, and Oklahoma: U.S. Geological Survey Hydrologic Investigations Atlas $\mathrm{HA}-711-\mathrm{K}, 4$ sheets, scale $1: 750,000$. 
Irza, T.J., 1966, Preliminary flood-frequency relations for small streams in Kansas: U.S. Geological Survey Open-File Report, 19 p.

James, I.C., II, 1967, Flood runoff from partially urbanized areas, Wichita, Kansas-Report No. 1, Analysis of initial conditions: U.S. Geological Survey Open-File Report, 62 p.

1968, Streamflow generalization in an area of the central United States: U.S. Geological Survey OpenFile Report, $60 \mathrm{p}$.

Jenkins, E.D., and Pabst, M.E., 1975, Water development for irrigation in northwestern Kansas: U.S. Geological Survey Open-File Report 4-75, 39 p.

1977, Water-resources reconnaissance of Ness County, west-central Kansas: Kansas Geological Survey Irrigation Series 3, 26 p.

Johnson, C.R., 1956, The ground-water resources of the Prairie Dog Valley area in Kansas: Kansas Geological Survey Open-File Report 56-4, 171 p.

1958, Geology and ground-water resources of Logan County, Kansas: Kansas Geological Survey Bulletin 129, $175 \mathrm{p}$.

*Johnson, W.D., 1901, The High Plains and their utilization: U.S. Geological Survey 21 st Annual Report, Part IV-C, p. 743-768.

* 1902, The High Plains and their utilization (conclusion): U.S. Geological Survey 22nd Annual Report, Part IV-C, p. 671-690.

*Johnson, W.D., Jr., Adkison, W.L., and Wagner, H.C., 1967, Geology of Shawnee County, Kansas: U.S. Geological Survey Bulletin 1215, 254 p.

Jordan, P.R., 1977, Streamflow transmission losses in western Kansas: Proceedings, American Society Civil Engineers, Hydraulics Division Journal, v. 103, no. HY8, p. 905-919.

1978a, Loss of high flows by seepage from stream channels in Kansas: Kansas Water News, v. 21, nos. 1 and 2, p. 30-34.

$1978 b$, Statistical summary of streamflow data for Kansas streams in the Arkansas River Basin: Kansas Water Resources Board Technical Report No. 14A, $206 \mathrm{p}$.

1979a, Relation of sediment yield to climatic and physical characteristics in the Missouri River Basin: U.S. Geological Survey Water-Resources Investigations Report 79-49, 26 p.

1979b, Statistical summary of streamflow data for Kansas streams in the Missouri River Basin: Kansas Water Resources Board Technical Report No. 14B, $334 \mathrm{p}$.
1982, Rainfall-runoff relations and expected streamflow in western Kansas: Kansas Water Office Bulletin No. 25, 42 p.

1983, Magnitude and frequency of low flows of unregulated streams in Kansas, and estimation of flowduration curves for ungaged sites: Kansas Water Office Technical Report No. 17, 55 p.

1984, Magnitude and frequency of high flows of unregulated streams in Kansas: U.S. Geological Survey Open-File Report 84-453, 45 p.

1985, Design of a sediment data-collection program in Kansas as affected by time trends: U.S. Geological Survey Water-Resources Investigations Report 85-4204, 114 p.

1986a, Kansas surface-water resources, in Moody, D.W., Chase, E.B., and Aronson, D.A., compilers, National water summary 1985 - Hydrologic events and surface-water resources: U.S. Geological Survey Water-Supply Paper 2300, p. 237-244.

1986b, Magnitude and frequency of high flows of unregulated streams in Kansas: U.S. Geological Survey Water-Supply Paper 2280, 35 p.

Jordan, P.R., and Hart, R.J., 1985, Transit losses and travel times for water-supply releases from Marion Lake during drought conditions, Cottonwood River, east-central Kansas: U.S. Geological Survey WaterResources Investigations Report 85-4263, 41 p.

Jordan, P.R., and Hedman, E.R., 1970, Evaluation of the surface-water data program in Kansas: Kansas Water Resources Board Bulletin No. 12, 49 p.

Jordan, P.R., and Irza, T.J., 1975, Kansas streamflow characteristics, magnitude and frequency of floods in Kansas, unregulated streams: Kansas Water Resources Board Technical Report No. 11, 34 p.

Jordan, P.R., and Jennings, M.E., 1991, Quantification of floods and droughts, in Paulson, R.W., Chase, E.B., Roberts, R.S., and Moody, D.W., compilers, National water summary 1988-89-Hydrologic events and floods and droughts: U.S. Geological Survey WaterSupply Paper 2375, p. 158-161.

*Jordan, P.R., Jones, B.F., and Petri, L.R., 1964, Chemical quality of surface waters and sedimentation in the Saline River Basin, Kansas: U.S. Geological Survey Water-Supply Paper 1651, 90 p.

Jordan, P.R., and Stamer, J.K., eds., 1991, Surface-waterquality assessment of the lower Kansas River Basin, Kansas and Nebraska-Analysis of available waterquality data through 1986: U.S. Geological Survey Open-File Report 91-75, 172 p. 
Jorgensen, D.G., 1988a, Estimating permeability in water-saturated formations: The Log Analyst, November-December 1988, p. 401-409.

$1988 b$, Using geophysical logs to estimate porosity, water resistivity, and intrinsic permeability: U.S. Geological Survey Water-Supply Paper 2321, 24 p.

1989, Paleohydrology of the Anadarko Basin, central United States, in Johnson, K.S., ed., Anadarko Basin Symposium, 1988: Oklahoma Geological Survey Circular 90, p. 176-193.

1993, Paleohydrology of the Central United States: U.S. Geological Survey Bulletin 1989-D, 32 p.

Jorgensen, D.G., Gogel, Tony, and Signor, D.C., 1982, Determination of flow in aquifers containing variabledensity water, in Ground Water Monitoring Review: Worthington, Ohio, Water Well Journal Publishing Co., v. 2 , no. 2 , Spring 1982, p. $40-45$.

Jorgensen, D.G., Grubb, H.F., Baker, C.H., Jr., Hilmes, G.E., and Jenkins, E.D., 1982, A numerical model to evaluate proposed ground-water allocations in southwest Kansas: U.S. Geological Survey WaterResources Investigations Report 82-4095, 46 p.

Jorgensen, D.G., Helgesen, J.O., and Imes, J.L., 1993, Regional aquifers in Kansas, Nebraska, and parts of Arkansas, Colorado, Missouri, New Mexico, Oklahoma, South Dakota, Texas, and Wyoming-Geohydrologic framework: U.S. Geological Survey Professional Paper 1414-B, 25 pls., 72 p.

Jorgensen, D.G., Helgesen, J.O., Leonard, R.B., and Signor, D.C., 1986, Equivalent freshwater head and dissolved-solids concentration of water in rocks of Cambrian, Ordovician, and Mississippian age in the northern Midcontinent, U.S.A.: U.S. Geological Survey Miscellaneous Field Studies Map MF-1835-B, 2 sheets, scale $1: 1,000,000$.

Jorgensen, D.G., and Signor, D.C., 1981, Plan of study for the Central Midwest regional aquifer system analysis in parts of Arkansas, Colorado, Kansas, Missouri, Nebraska, New Mexico, Oklahoma, South Dakota, and Texas: U.S. Geological Survey Water-Resources Investigations, Open-File Report 81-206, 28 p.

Jorgensen, D.G., Signor, D.C., and Imes, J.L., 1989a, Accounting for intracell flow in models with emphasis on water table recharge and stream-aquifer interaction-1. Problems and concepts: Water Resources Research, v. 25, no. 4, April 1989, p. 669-676.

$1989 b$, Accounting for intracell flow in models with emphasis on water table recharge and stream-aquifer interaction-2. A procedure: Water Resources Research, v. 25, no. 4, April 1989, p. 677-684.
Jorgensen, D.G., and Stullken, L.E., 1981, Hydrology and model of North Fork Solomon River Valley, Kirwin Dam to Waconda Lake, north-central Kansas: Kansas Geological Survey Irrigation Series 6, $34 \mathrm{p}$.

Jungmann, W.L., 1966, Geology and ground-water resources of Neosho County, Kansas: Kansas Geological Survey Bulletin 183, 46 p.

Jungmann, W.L., and Williams, C.C., 1968, Geology and ground water in Labette County, Kansas: U.S. Geological Survey Hydrologic Investigations Atlas HA-279, 1 sheet, scale 1:63,390.

Juracek, K.E., 1991, Application of geographic information system technology to ground-water management in Kansas: Program of abstracts, 36th Annual Midwest Ground Water Conference, Indianapolis, Ind., October 9-11, 1991, p. 74.

1992a, Determining water availability in Kansas: Geo Info Systems, v. 2, no. 8, p. 52-57.

1992b, The utility of geographic information system technology for addressing the effect of agricultural pesticide use on surface-water quality: Proceedings of 9th Annual Water and the Future of Kansas Conference, Manhattan, Kans., March 4-5, 1992, p. 29-30.

1992c, Use of a geographic information system to assist with studies of the availability and use of water in Kansas: U.S. Geological Survey Open-File Report 92-142, 14 p.

1994a, Concentrations of triazine herbicides in the unsaturated zone in western Harvey County, Kansas, spring and fall 1992-93: U.S. Geological Survey Open-File Report 94-497, 23 p.

1994b, Description and use of a geographicinformation-system-based water information management and analysis system (WIMAS): U.S. Geological Survey Open-File Report 94-46, 20 p.

$1994 c$, Interactive query of State water-appropriations and water-use information: Geo Info Systems, November/December 1994, p. 44-48.

Juracek, K.E., and Kenny, J.F., 1993a, Management and analysis of water-use data using a geographic information system: Water Resources Bulletin, v. 29, no. 6, p. $973-979$.

1993b, Management and analysis of water-use data using a geographic information system, in Harlin, J.M., and Lanfear, K.J., eds., Geographic information systems and water resources: American Water Resources Association, Proceedings, p. 483-490, 627-628.

Juracek, K.E., Kenny, J.F., and Perry, C.A., 1992, Herbicides, water quality and you: U.S. Geological Survey Open-File Report 92-127, video. 
Kansas Water Board, 1958-62, State water plan studies, Part A-Preliminary appraisal of Kansas water problems:

Sec. 1, Marais des Cygnes Unit, June 1958, 189 p.

Sec. 2, Cimarron Unit, Sept. 1958, 124 p.

Sec. 3, Kansas Unit, June 1959, 193 p.

Sec. 4, Lower Arkansas Unit, Jan. 1960, 177 p.

Sec. 5, Walnut-Verdigris Unit, June 1960, 160 p.

Sec. 6, Upper Republican Unit, June 1960, 111 p.

Sec. 7, Neosho Unit, June 1961, 134 p.

Sec. 8, Solomon-Saline Unit, June 1961, 154 p.

Sec. 9, Lower Republican Unit, June 1961, 99 p.

Sec. 10, Missouri Unit, June 1962, 109 p.

Sec. 11, Upper Arkansas Unit, June 1962, 121 p.

Sec. 12, Smoky Hill Unit, June 1962, 125 p.

Kastner, W.M., 1974, Application of statistical techniques to the estimation of ground-water withdrawals in northwestern Kansas: U.S. Geological Survey WaterResources Investigations Report 41-74, 11 p.

Keene, K.M., and Bayne, C.K., 1977, Ground water from Lower Cretaceous rocks in Kansas: Kansas Geological Survey Chemical Quality Series 5, $18 \mathrm{p}$.

*Keene, K.M., and Pabst, M.E., 1971, Hydrogeologic data from Gove, Logan, and Wallace Counties, Kansas: Kansas Geological Survey Basic-Data Series, GroundWater Release 2, 76 p.

*Keene, K.M., Pearl, R.H., and Pabst, M.E., 1969, Hydrogeologic data from Cheyenne, Decatur, Rawlins, Sheridan, Sherman, and Thomas Counties, Kansas: Kansas Geological Survey Basic-Data Series, GroundWater Release 1, $113 \mathrm{p}$.

Kenny, J.F., 1986, Water demands in Kansas, 1944-84: U.S. Geological Survey Water-Resources Investigations Report 86-4038, 17 p.

1991, Reported water use in Kansas, 1987: U.S. Geological Survey Open-File Report 91-212, 39 p.

1993, Kansas stream water quality, in Paulson, R.W., Chase, E.B., Williams, J.S., and Moody, D.W., compilers, National water summary 1990-91-Hydrologic events and stream water quality: U.S. Geological Survey Water-Supply Paper 2400, p. 277-284.

Kenny, J.F., Bevans, H.E., and Diaz, A.M., 1982, Physical and hydrological environments of the Mulberry coal reserves in eastern Kansas: U.S. Geological Survey Water-Resources Investigations Report 82-4074, $50 \mathrm{p}$.

Kenny, J.F., and Combs, L.J., 1983, Water-resources investigations of the U.S. Geological Survey in Kansas-Fiscal years 1981 and 1982: U.S. Geological Survey Open-File Report 83-932, 87 p.
Kenny, J.F., Hansen, C.V., and Wolf, R.J., 1993, Geohydrologic systems in Kansas-Geohydrology of the upper aquifer unit in the Western Interior Plains aquifer system: U.S. Geological Survey Hydrologic Investigations Atlas $\mathrm{HA}-722-\mathrm{H}, 2$ sheets, scale $1: 1,500,000$.

Kenny, J.F., and McCauley, J.R., 1982, Remote-sensing investigations in the coal fields of southeastern Kansas, in Johannsen, C.J., and Sanders, J.L., eds., chap. 29 of Remote sensing for resource management (outgrowth of a national conference by the same name, held October 28-30, 1980, at Kansas City, Mo., 665 p.): Ankeny, Iowa, Soil Conservation Society of America, p. 338-346.

1983, Application of remote-sensing techniques to hydrologic studies in selected coal-mined areas of southeastern Kansas: U.S. Geological Survey WaterResources Investigations Report 83-4007, 33 p.

*Kinnison, H.B., 1925, Surface waters of Kansas, 1919-1924: Kansas Water Commission, 259 p.

Kolpin, D.W., Burkart, M.R., and Thurman, E.M., 1993, Hydrogeologic, water-quality, and land-use data for the reconnaissance of herbicides and nitrate in nearsurface aquifers of the midcontinental United States, 1991: U.S. Geological Survey Open-File Report 93-114, 61 p.

1994, Herbicides and nitrate in near-surface aquifers in the midcontinental United States, 1991: U.S. Geological Survey Water-Supply Paper 2413, 34 p.

Krothe, N.C., and Oliver, J.W., 1982, Sulfur isotopic composition and water chemistry in water from the High Plains aquifer, Oklahoma Panhandle and southwestern Kansas: U.S. Geological Survey WaterResources Investigations Report 82-12, 28 p.

Krothe, N.C., Oliver, J.W., and Weeks, J.B., 1982, Dissolved solids and sodium in water from the High Plains aquifer in parts of Colorado, Kansas, Nebraska, New Mexico, Oklahoma, South Dakota, Texas, and Wyoming: U.S. Geological Survey Hydrologic Investigations Atlas HA-658, 2 sheets, scale $1: 2,500,000$.

Kume, Jack, 1984, Geohydrology and chemical quality of water in Middle and Upper Jurassic and Lower Cretaceous rocks, western Kansas: U.S. Geological Survey Water-Resources Investigations Report 84-4045, $54 \mathrm{p}$.

Kume, Jack, Dunlap, L.E., Gutentag, E.D., and Thomas, J.G., 1979, Hydrologic and related data for watersupply planning in an intensive-study area, northeastern Wichita County, Kansas: U.S. Geological Survey Water-Resources Investigations Report 79-105, $51 \mathrm{p}$. 
Kume, Jack, Lindgren, R.J., and Stullken, L.E., 1985, Projected ground-water development, ground-water levels, and stream-aquifer leakage in the South Fork Solomon River Valley between Webster Reservoir and Waconda Lake, north-central Kansas, 1979-2020: U.S. Geological Survey Water-Resources Investigations Report 85-4216, $42 \mathrm{p}$.

Kume, Jack, and Spinazola, J.M., 1982, Geohydrologic data from sandstone aquifers in southwestern Kansas: U.S. Geological Survey Open-File Report 82-868, $112 \mathrm{p}$.

1983, Depth and thickness of selected units in Upper Permian, Upper Jurassic, and Lower Cretaceous rocks in southwestern Kansas: U.S. Geological Survey Water-Resources Investigations Report 83-4095, 7 sheets, scale 1:500,000.

1985, Geohydrology of sandstone aquifers in southwestern Kansas: Kansas Geological Survey Irrigation Series 8, 49 p.

Landis, E.R., 1960, Uranium content of ground and surface waters in a part of the central Great Plains: U.S. Geological Survey Bulletin 1087-G, p. 223-258.

Lane, C.W., 1960, Geology and ground-water resources of Kingman County, Kansas: Kansas Geological Survey Bulletin 144, $174 \mathrm{p}$.

Lane, C.W., and Miller, D.E., 1965a, Geohydrology of Sedgwick County, Kansas: Kansas Geological Survey Bulletin 176, $100 \mathrm{p}$.

1965b, Logs of wells and test holes in Sedgwick County, Kansas: Kansas Geological Survey Special Distribution Publication 22, 175 p.

Lane, C.W., Reavis, E.L., and Stramel, G.J., 1962, Emergency water supplies in the Wichita area, Kansas: U.S. Geological Survey Hydrologic Investigations Atlas HA-58, 36 p., 1 sheet, scale 1:250,000.

La Rocque, G.A., Jr., 1966, General availability of ground water and depth to water level in the Missouri River Basin: U.S. Geological Survey Hydrologic Investigations Atlas HA-217, 1 sheet, scale 1:2,500,000.

Latta, B.F., 1940, Memorandum in regard to the possibility of leakage of the reservoir basin of the proposed Sedgwick County Lake, in south-central Kansas: Kansas Geological Survey Open-File Report 40-10, $11 \mathrm{p}$.

*__ 1941, Geology and ground-water resources of Stanton County, Kansas: Kansas Geological Survey Bulletin 37, $119 \mathrm{p}$.

*___ 1944, Geology and ground-water resources of Finney and Gray Counties, Kansas: Kansas Geological Survey Bulletin 55, $272 \mathrm{p}$.

*__ 1948a, Geology and ground-water resources of Kiowa County, Kansas: Kansas Geological Survey Bulletin 65, $151 \mathrm{p}$.
*___ 1948b, Ground-water supplies at Hays, Victoria, Walker, Gorham, and Russell, Kansas, with special reference to future needs: Kansas Geological Survey Bulletin 76, pt. 6, p. 121-196.

*__ 1949, Ground-water conditions in the Smoky Hill Valley in Saline, Dickinson, and Geary Counties, Kansas: Kansas Geological Survey Bulletin 84, 152 p.

*__ 1950, Geology and ground-water resources of Barton and Stafford Counties, Kansas: Kansas Geological Survey Bulletin 88, 228 p.

Layton, D.W., and Berry, D.W., 1973, Geology and ground-water resources of Pratt County, south-central Kansas: Kansas Geological Survey Bulletin 205, 33 p.

Leahy, P.P., and Stamer, J.K., 1994, Herbicides in the lower Kansas River Basin-Policy relevant findings from the U.S. Geological Survey's National WaterQuality Assessment [abs.]: Program of 1994 Annual Meeting of the Geological Society of America, Seattle, Wash., October 24-27, 1994, p. A-106.

Leeson, E.R., 1957, History of natural flow, Kansas River: U.S. Geological Survey Open-File Report, 5 p.

Leonard, A.R., 1952, Geology and ground-water resources of the North Fork Solomon River in Mitchell, Osborne, Smith, and Phillips Counties, Kansas: Kansas Geological Survey Bulletin 98, 150 p.

Leonard, A.R., and Berry, D.W., 1961, Geology and ground-water resources of southern Ellis County and parts of Trego and Rush Counties, Kansas: Kansas Geological Survey Bulletin 149, 156 p.

*Leonard, R.B., 1964a, A method for evaluating oil-fieldbrine pollution of the Walnut River in Kansas, in Geological Survey Research, 1964, Chapter B: U.S. Geological Survey Professional Paper 501-B, p. B173-B176.

$1964 \mathrm{~b}$, Cooperative water-quality investigations of the Walnut River Basin, Kansas: Kansas Water News, v. 7 , no. 5 , p. 5-6.

$1964 c$, Results of four chemical-quality surveys of the Walnut River Basin, Kansas (December 1961 to October 1963): Kansas Department of Health and Environment Bulletin No. 1-3, 38 p.

$1969 a$, Effect of irrigation on the chemical quality of low streamflow adjacent to Cedar Bluff Irrigation District, Kansas, a progress report: Kansas Department of Health and Environment Bulletin No. 1-10, $17 \mathrm{p}$.

$1969 \mathrm{~b}$, Time of travel study on the Big Blue River: Kansas Water News, v. 12, no. 3, p. 7 and 8. 
1970, Variations in the chemical quality of ground water beneath an irrigated field, Cedar Bluff Irrigation District, Kansas: Kansas Department of Health and Environment Bulletin No. 1-11, 20 p.

1972, Chemical quality of water in the Walnut River Basin, south-central Kansas: U.S. Geological Survey Water-Supply Paper 1982, 113 p.

1974, Changes in chemical quality of water, Cedar Bluff Irrigation District area, west-central Kansas: Kansas Geological Survey Chemical Quality Series 1, $72 \mathrm{p}$.

Leonard, R.B., and Kleinschmidt, M.K., 1976, Saline water in the Little Arkansas River Basin area, southcentral Kansas: Kansas Geological Survey Chemical Quality Series 3, 24 p.

Leonard, R.B., and Morgan, C.O., 1970, Application of computer techniques to seepage-salinity surveys in Kansas: Kansas Geological Survey Special Distribution Publication 47, 44 p.

Leonard, R.B., and Shah, K.L., 1964, The relation of the chemical quality of the Whitewater River at Towanda to that of the Walnut River at Winfield, Kansas, during the 1963 water year: Kansas Department of Health and Environment Bulletin, No. 1-2, 18 p.

Leonard, R.B., Signor, D.C., Jorgensen, D.G., and Helgesen, J.O., 1983, Geohydrology and hydrochemistry of the Dakota aquifer, central United States: American Water Resources Association, Water Resources Bulletin, v. 19, no. 6, December 1983, p. 903-911.

Leonard, R.B., and Stoltenberg, G.A., 1972, Compilation of data for water-quality investigation, Cedar Bluff Irrigation District, Kansas: Kansas Department of Health and Environment Bulletin No. 1-12, 158 p.

Lindgren, R.J., 1982, Determination of irrigation pumpage in parts of Kearny and Finney Counties, southwestern Kansas: U.S. Geological Survey Water-Resources Investigations Report 82-4011, 26 p.

Livingston, R.K., and Medina, K.D., 1984, Water-data program of the U.S. Geological Survey in Kansas, fiscal year 1983: U.S. Geological Survey WaterResources Investigations Report 84-4306, 33 p.

Lobmeyer, D.H., and Sauer, C.G., 1974, Water resources of Hamilton County, southwestern Kansas: U.S. Geological Survey Hydrologic Investigations Atlas HA-516, 2 sheets, scales 1:250,000 and $1: 500,000$.

Lobmeyer, D.H., and Weakly, E.C., 1978, Water in Dakota Formation, Hodgeman and northern Ford Counties, southwestern Kansas: U.S. Geological Survey Open-File Report 78-886, 81 p.
1979, Water in the Dakota Formation, Hodgeman and northern Ford Counties, southwestern Kansas: Kansas Geological Survey Irrigation Series 5, $41 \mathrm{p}$.

*Lohman, S.W., 1941, Ground-water conditions in the vicinity of Lawrence, Kansas: Kansas Geological Survey Bulletin 38, pt. 2, 64 p.

*__ 1942, Ground-water supplies available for national defense industries in south-central Kansas: Kansas Geological Survey Bulletin 41, pt. 1,19 p.

Lohman, S.W., and Burtis, V.M., 1953, Areas of principal ground-water investigations in the Arkansas, White, and Red River Basins: U.S. Geological Survey Hydrologic Investigations Atlas HA-2, I sheet, scale $1: 2,500,000$.

Lohman, S.W., and others, 1953, General availability of ground water and depths to water levels in the Arkansas, White, and Red River Basins: U.S. Geological Survey Hydrologic Investigations Atlas HA-3, 1 sheet, scale 1:2,500,000.

Lohman, S.W., and Frye, J.C., 1940, Geology and groundwater resources of the Equus-beds area in south-central Kansas: Economic Geology, v. 35, no. 7, p. 839-866.

*Lohman, S.W., Frye, J.C., Waite, H.A., Fishel, V.C., McLaughlin, T.G., Latta, B.F., and Abernathy, G.E., 1942, Ground-water supplies available in Kansas for national defense industries: Kansas Geological Survey Bulletin 41, pt. 2, p. 21-28.

Lohman, S.W., and Mitchell, Alexander, 1940, Memorandum in regard to prospecting for a softer water supply for the Kansas State Penitentiary at Lansing, Kansas: U.S. Geological Survey Open-File Report, $17 \mathrm{p}$.

Longwill, S.M., McNellis, J.M., and Posson, D.R., 1980, The use of minicomputers in a distributed information processing system-A feasibility study: U.S. Geological Survey Open-File Report 80-326, 68 p.

*Lowell, B.H., Morgan, C.O., and McNellis, J.M., 1970, Brief descriptions of and examples of output from computer programs developed for use with water data in Kansas: Kansas Geological Survey Special Distribution Publication 48, 54 p.

Luckey, R.R., Gutentag, E.D., Heimes, F.J., and Weeks, J.B., 1988, Effects of future ground-water pumpage on the High Plains aquifer in parts of Colorado, Kansas, Nebraska, New Mexico, Oklahoma, South Dakota, Texas, and Wyoming: U.S. Geological Survey Professional Paper 1400-E, $44 \mathrm{p}$.

Mack, L.E., 1962, Geology and ground-water resources of Ottawa County, Kansas: Kansas Geological Survey Bulletin 154, $145 \mathrm{p}$.

Marcher, M.V., Kenny, J.F., and others, 1984, Hydrology of area 40, Western Region, Interior Coal Province, Kansas, Oklahoma, and Missouri: U.S. Geological Survey Water-Resources Investigations, Open-File Report 83-266, 97 p. 
Mayes, J.L., and Culbertson, Don, 1964, Chemical quality of surface waters in Kansas, 1962 water year: Kansas Department of Health and Environment Bulletin No. 1-4, 61 p.

Mayes, J.L., and Diaz, A.M., 1965, Chemical quality of surface waters in Kansas, 1963 water year: Kansas Department of Health and Environment Bulletin No. 1-8, 67 p.

Mayes, J.L., Stoltenberg, G.A., and Burris, N.J., 1965, Chemical quality of public water supplies in Kansas: Kansas Department of Health and Environment Bulletin No. 1-7, 39 p.

McClain, T.J., and Jenkins, E.D., 1971, Digital simulation of the Ogallala aquifer in Sherman County, northwestern Kansas, in Ogallala Aquifer Symposium: Texas Tech University Special Report 39, p. 72-88.

McClain, T.J., Jenkins, E.D., Keene, K.M., and Pabst, M.E., 1975, Water resources of Gove, Logan, and Wallace Counties, west-central Kansas: U.S. Geological Survey Hydrologic Investigations Atlas HA-521, 2 sheets, scales $1: 250,000$ and $1: 500,000$.

McElwee, C.D., 1977, The Theis equation--Evaluation, sensitivity to storage and transmissivity, and automated fit of pump test data: Kansas Geological Survey OpenFile Report 77-5, $38 \mathrm{p}$.

McElwee, C.D., and Yukler, M.R., 1978, Sensitivity of groundwater models with respect to variations in transmissivity and storage: American Geophysical Union, Water Resources Research, v. 14, no. 3, p. $451-459$.

McGovern, H.E., 1971, Geology and ground water in the Ogallala Formation and undifferentiated Pleistocene deposits, southwestern Kansas, in Ogallala Aquifer Symposium: Texas Tech University Special Report 39, p. 15-29.

1984, Overview of the Dakota aquifer in Kansas, in Jorgensen, D.G., and Signor, D.C., eds., Geohydrology of the Dakota aquifer: National Water Well Association, Proceedings of First C.V. Theis Conference on Geohydrology, Lincoln, Nebr., October 5-6, 1982, p. 58-61.

McGovern, H.E., and Combs, L.J., 1979, Water-resources investigations in Kansas- Fiscal year 1978: U.S. Geological Survey Open-File Report 79-561, 85 p.

1981, Water-resources investigations of the U.S. Geological Survey in Kansas-Fiscal years 1979 and 1980: U.S. Geological Survey Water-Resources Investigations, Open-File Report 81-348, $107 \mathrm{p}$.

McGovern, H.E., and Long, W.A., 1974, Ground water in Gray County, southwestern Kansas: U.S. Geological Survey Hydrologic Investigations Atlas HA-517, 2 sheets, scale $1: 250,000$.
McGovern, H.E., and Wolf, R.J., 1993, Geohydrologic systems in Kansas-Geohydrology of the Great Plains aquifer system: U.S. Geological Survey Hydrologic Investigations Atlas HA-722-G, 2 sheets, scales $1: 1,000,000,1: 2,000,000$, and 1:3,000,000.

*McLaughlin, T.G., 1942, Geology and ground-water resources of Morton County, Kansas: Kansas Geological Survey Bulletin 40, $126 \mathrm{p}$.

* _ 1943, Geology and ground-water resources of Hamilton and Kearny Counties, Kansas: Kansas Geological Survey Bulletin 49, 220 p.

*__ 1946, Geology and ground-water resources of Grant, Haskell, and Stevens Counties, Kansas: Kansas Geological Survey Bulletin 61, 221 p.

* _ 1949, Geology and ground-water resources of Pawnee and Edwards Counties, Kansas: Kansas Geological Survey Bulletin 80, 189 p.

McNellis, J.M., 1973, Geology and ground-water resources of Rush County, central Kansas: Kansas Geological Survey Bulletin 207, 45 p.

McNellis, J.M., and Morgan, C.O., 1969, Modified Piper diagrams by the digital computer: Kansas Geological Survey Special Distribution Publication 45, $36 \mathrm{p}$.

McNellis, J.M., Morgan, C.O., and Lowell, B.H., 1968, Digital computer applications that facilitate collection and interpretation of ground-water data, in International Association Scientific Hydrology, The use of analog and digital computers in hydrology-A symposium: International Association Scientific Hydrology Publication No. 81 A1HS, v. 2, p. 561-568.

1969, Computer-produced tables, maps, and diagrams as tools in the interpretation of brine data from southeastern Kansas (U.S.A.): Chemical Geology, Amsterdam, v. 4, p. 303-324.

Medina, K.D., 1987a, Analysis of surface-water data network in Kansas for effectiveness in providing regional streamflow information, with a section on Theory and application of generalized least squares, by G.D. Tasker: U.S. Geological Survey Water-Supply Paper 2303, 28 p.

1987b, Floodflow characteristics at proposed bridge site for State Highway 99, Kansas River at Wamego, Kansas: U.S. Geological Survey Open-File Report 87-470, $13 \mathrm{p}$.

Medina, K.D., and Geiger, C.O., 1984, Evaluation of the cost effectiveness of the 1983 stream-gaging network in Kansas: U.S. Geological Survey Water-Resources Investigations Report 84-4107, $57 \mathrm{p}$.

*Meinzer, O.E., 1915, Preliminary report on ground water for irrigation in the vicinity of Wichita, Kansas: U.S. Geological Survey Water-Supply Paper 345-A, 9 p. 
Meyer, M.T., 1994, Geochemistry of cyanazine and its metaboliltes-Indicators of contaminant transport in surface water of the midwestern United States: Lawrence, University of Kansas, Ph.D. dissertation, $362 \mathrm{p}$.

Meyer, M.T., Mills, M.S., and Thurman, E.M., 1993, Automated solid-phase extraction of herbicides from water for gas chromatographic/mass spectrometric analysis: Journal of Chromatography, v. 629, p. 55-59.

Meyer, M.T., and Thurman, E.M., 1993a, Cyanazine metabolites in surface water-The transport and degradation of labile herbicides [abs.], in Proceedings of spring meeting, American Geophysical Union, Mineralogical Society of America, and Geochemical Society, Baltimore, Md., May 24-28, 1993: EOS, Transactions of the American Geophysical Union, April 20, 1993, p. 135.

1993b, Cyanazine metabolites in surface water-The transport and degradation of labile herbicides [abs.], in Programs and proceedings of symposium on agricultural nonpoint sources of contaminants-Focus on herbicides, Lawrence, Kans., September 28-29, 1993: U.S. Environmental Protection Agency, Region VII, and U.S. Geological Survey, p. 21.

1993c, The degradation and transport of cyanazine metabolites in surface water of the midwestern United States, in Morganwalp, D.W., and Aronson, D.A., compilers, U.S. Geological Survey Toxic Substances Hydrology Program-Abstracts of the Technical Meeting, Colorado Springs, Colo., September 20-24, 1993: U.S. Geological Survey Open-File Report 93-454, p. 87.

Meyer, M.T., Thurman, E.M., and Bannister, Robert, 1989, Concentrating suspended sediment for organic analysis, in Pederson, G.L., and Smith, M.M., compilers, U.S. Geological Survey Second National Symposium on Water Quality-Abstracts of the Technical Sessions, Orlando, Fla., November 12-17, 1989: U.S. Geological Survey Open-File Report 89-409, p. 61.

${ }^{*}$ Meyer, W.R., 1963, Use of a neutron moisture probe to determine the storage coefficient of an unconfined aquifer: U.S. Geological Survey Professional Paper 450-E, p. E174-E176.

Meyer, W.R., Gutentag, E.D., and Lobmeyer, D.H., 1969, Finney County basic data: U.S. Geological Survey Open-File Report, 146 p.

1970, Geohydrology of Finney County, southwestern Kansas: U.S. Geological Survey Water-Supply Paper 1891, $117 \mathrm{p}$.

Meyers, J.S., 1962, Evaporation from the 17 western states, with a section on Evaporation rates, by T.J. Nordenson:
U.S. Geological Survey Professional Paper 272-D, p. $71-100$.

Miller, D.E., 1966, Geology and ground-water resources of Miami County, Kansas: Kansas Geological Survey Bulletin 181, $66 \mathrm{p}$.

1969, Geology and ground-water resources of Allen County, Kansas: Kansas Geological Survey Bulletin 195, $50 \mathrm{p}$.

Mills, M.S., 1991, Field dissipation of encapsulated herbicides-Geochemistry and degradation: Lawrence, University of Kansas, master's thesis, 98 p.

1994, The organic geochemistry of natural aquatic foam: Lawrence, University of Kansas, Ph.D. dissertation, $274 \mathrm{p}$.

Mills, M.S., and Thurman, E.M., 1992, Mixed-mode isolation of triazine metabolites in soil and aquifer sediments using automated solid-phase extraction: Analytical Chemistry, v. 64, p. 1985-1990.

1994a, Preferential dealkylation of s-triazine herbicides in the unsaturated zone: Environmental Science and Technology, v. 28, no. 4, p. 600-605.

$1994 \mathrm{~b}$, Reduction of nonpoint source contamination of surface water and groundwater by starch encapsulation of herbicides: Environmental Science and Technology, v. 28, no. 1, p. 73-79.

Mills, M.S., Thurman, E.M., and Patel, Ragina, 1991 , Isolation of polar metabolites of atrazine by mixedmode adsorption: Abstracts of papers presented at 1991 Pittsburgh Conference \& Exposition on Analytical Chemistry and Applied Spectrometry, Chicago, Ill, March 3-8, 1991, p. 982.

Mills, M.S., Thurman, E.M., and Pedersen, M.J., 1993, Application of mixed-mode, solid-phase extraction in environmental and clinical chemistry-Combining hydrogen-bonding, cation-exchange and Van der Waals interactions: Journal of Chromatography, v. 629, p. 11-21.

Mills, M.S., Thurman, E.M., and Wing, R.E., 1990, Dissipation of starch-encapsulated herbicides-A field comparison with powdered herbicides, in Abstract for the AGU Fall Meeting, December 3-7, 1990, San Francisco, Calif.: EOS, Transactions of the American Geophysical Union, v. 71, no. 43, October 23, 1990, p. 1331-1332.

Mills, M.S., Thurman, E.M., Wing, R.E., and Barnes, P.L., 1991a, Dissipation of starch-encapsulated herbicides-A field comparison with powdered herbicides, in Mallard, G.E., and Aronson, D.A., compilers, Abstracts of the Technical Meeting, U.S. Geological Survey Toxic Substances Hydrology Program, Monterey, Calif., March 11-15, 1991: U.S. Geological Survey Open-File Report 91-88, p. 13. 
1991b, Dissipation of starch-encapsulated herbicides-A field comparison with powdered herbicides, in Mallard, G.E., and Aronson, D.A., eds., U.S. Geological Survey Toxic Substances Hydrology Program-Proceedings of the Technical Meeting, Monterey, Calif., March 11-15, 1991: U.S. Geological Survey Water-Resources Investigations Report 91-4034, p. 203-209.

*Moore, R.C., 1940, Ground-water resources of Kansas (with chapters by S.W. Lohman, J.C. Frye, H.A. Waite, T.G. McLaughlin, and B.F. Latta): Kansas Geological Survey Bulletin 27, 112 p.

Morgan, C.O., Dingman, R.J., and McNellis, J.M., 1966, Digital computer methods for water-quality data: Ground Water, Technical Division Journal, National Water Well Association, v. 4, no. 3, July, p. 35-42.

Morgan, C.O., and McNellis, J.M., 1969a, FORTRAN IV programs, KANS, for the conversion of General Land Office locations to latitude and longitude coordinates: Kansas Geological Survey Special Distribution Publication 42, $24 \mathrm{p}$.

$1969 \mathrm{~b}$, Stiff diagrams of water-quality data programmed for the digital computer: Kansas Geological Survey Special Distribution Publication 43, 26 p.

1971, Reduction of lithologic-log data to numbers for use in the digital computer: Mathematical Geology, v. 3 , no. 1, p. 79-86.

Morgan, C.O., McNellis, J.M., and Lowell, B.H., 1969, Computer applications in hydrology in Kansas, in Zeller, D.E., ed., Short papers on research in 1968: Kansas Geological Survey Bulletin 194, pt. 1, p. 3-7.

Morton, R.B., and Fader, S.W., 1975, Ground water in the Grand (Neosho) River Basin, Kansas and Oklahoma: U.S. Geological Survey Open-File Report 75-366, $35 \mathrm{p}$.

Mueller, D.K., DeWeese, L.R., Garner, A.J., and Spruill, T.B., 1991, Reconnaissance investigation of water quality, bottom sediment, and biota associated with irrigated drainage in the Middle Arkansas River Basin, Colorado and Kansas, 1988-89: U.S. Geological Survey Water-Resources Investigations Report 91-4060, 84 p.

Mundorff, J.C., 1958, Sediment studies in Kansas, 1957-1958: Kansas Water News, v. 2, no. 1, p. 6-7.

1961, A program of fluvial sediment investigations in Kansas: Kansas Water Resources Board Bulletin No. 6,48 p.

Mundorff, J.C., and Scott, C.H., 1964, Fluvial sediment in the lower Kansas River Basin - A progress report 1957-60: Kansas Water Resources Board Bulletin No. $7,67 \mathrm{p}$.
*Mundorff, J.C., and Waddell, K.M., 1966, Fluvial sediment and chemical quality of water in the Little Blue River Basin, Nebraska and Kansas: U.S. Geological Survey Water-Supply Paper 1819-H, p. $\mathrm{H} 1-\mathrm{H} 45$.

*Murphy, E.C., 1904, Destructive floods in the United States in 1903, contains Kansas floods and hydrographic data: U.S. Geological Survey Water-Supply Paper 96, $81 \mathrm{p}$.

*Murphy, E.C., and others, 1905, Destructive floods in the United States in 1904, contains Kansas floods: U.S. Geological Survey Water-Supply Paper 147, $206 \mathrm{p}$.

Myers, N.C., 1992, Chloride distribution in the alluvial aquifer adjacent to the Arkansas River between Hutchinson and Wichita, south-central Kansas: Kansas Academy of Science, Abstracts of Papers Presented at 124th Annual Meeting, Hutchinson, Kans., March 26-27, 1992, v. 11, p. 33

Myers, N.C., and Bigsby, P.R., 1989, Hydrogeology and ground-water-quality conditions at the Geary County Landfill, northeast Kansas, 1988: U.S. Geological Survey Water-Resources Investigations Report 89-4114, 41 p.

1990, Hydrogeology and ground-water-quality conditions at the Emporia-Lyon County Landfill, eastern Kansas, 1988: U.S. Geological Survey WaterResources Investigations Report 90-4043, 42 p.

Myers, N.C., Heck, B.A., and Hargadine, D.A., 1993, Hydrogeology and ground-water-quality conditions at the Sumner County Landfill, south-central Kansas, 1989-90: U.S. Geological Survey Water-Resources Investigations Report 92-4177, 52 p.

*Newell, F.H., 1895, Report of progress of the Division of Hydrography for 1893 and 1894: U.S. Geological Survey Bulletin 131, 126 p.

*__ 1898, Report of progress of stream measurements for the calendar year 1897: U.S. Geological Survey 19th Annual Report, Part IV, p. 1-632.

* _ 1899, Report of progress on stream measurements for the calendar year 1898: U.S. Geological Survey 20th Annual Report, Part IV, p. 1-562.

*__ 1900, Report of progress of stream measurements for the calendar year 1899: U.S. Geological Survey 21st Annual Report, p. 9-488.

*_ 1901, Report of progress of stream measurements for the calendar year 1900: U.S. Geological Survey 22nd Annual Report, p. 9-506.

Nuzman, C.E., and Meyer, W.R., 1965, Water-level change in Grant and Stanton Counties, Kansas, 1939-1965: Kansas Geological Survey Special Distribution Publication 18, 11 p. 
O'Connor, H.G., 1949, Notes on the ground-water resources of Chase County, Kansas: Transactions of the Kansas Academy of Science, v. 52, no. 3, p. 399-405.

* _ 1951, Ground-water resources of Chase County [Kansas]: Kansas Geological Survey, v. 11, pt. 3, p. $28-49$.

1953, Ground-water resources of Lyon County [Kansas]: Kansas Geological Survey, v. 12, pt. 3, p. 35-59.

1955, Ground-water resources of Osage County [Kansas]: Kansas Geological Survey, v. 13, pt. 3, p. $28-49$.

*

1960, Geology and ground-water resources of Douglas County, Kansas: Kansas Geological Survey Bulletin 148, 200 p.

1971, Geology and ground-water resources of Johnson County, northeastern Kansas: Kansas Geological Survey Bulletin 203, 68 p.

1973, Geohydrology for urban planning in Johnson County, northeastern Kansas: Kansas Geological Survey Open-File Report 73-9, 41 p.

1974, Geology and ground-water resources of Montgomery County, southeastern Kansas: Kansas Geological Survey Ground-Water Series 1, 12 p.

Osterkamp, W.R., 1977a, Effect of channel sediment on width-discharge relations, with emphasis on streams in Kansas: Kansas Water Resources Board Bulletin 21, $25 \mathrm{p}$.

1977b, Fluvial sediment in the Arkansas River Basin, Kansas: Kansas Water Resources Board Bulletin 19, $91 \mathrm{p}$.

1978a, Bed-and bank-sampling procedure at channel geometry sites: Proceedings of National Conference on Sampling, Validation, and Quality Control of Environmental Measurements, Atlanta, Ga., May 31-June 2, 1978.

1978b, Gradient, discharge, and particle-size relations of alluvial channels in Kansas, with observations on braiding: American Journal of Science, v. 278, November 1978, p. 1253-1268.

1979a, Bed- and bank-material sampling procedure at channel-geometry sites: National Conference on Quality Assurance of Environmental Measurement, Information Transfer Inc., p. 86-89.

1979b, Invariant power functions as applied to fluvial morphology, in Rhodes, D.D., and Williams, G.R., eds., Adjustments of the fluvial system: Kendall/Hunt Publishing Co., p. 33-54.
$1979 c$, Variation of alluvial-channel width with discharge and character of sediment: U.S. Geological Survey Water-Resources Investigations Report 79-15, $11 \mathrm{p}$.

1980, Sediment-morphology relations of alluvial channels: American Society Civil Engineers Proceedings, Watershed Management Symposium, Boise, Idaho, $12 \mathrm{p}$.

Osterkamp, W.R., Curtis, R.E., Jr., and Crowther, H.G., 1981, Sediment and channel-geometry investigations for the Kansas River Bank-Stabilization Study, Kansas, Nebraska, and Colorado: U.S. Geological Survey Water-Resources Investigations, Open-File Report 81-128, 72 p.

Osterkamp, W.R., and Hedman, E.R., 1977, Variation of width and discharge for natural high-gradient stream channels: American Geophysical Union, Water Resources Research, v. 13, no. 2, p. 256-258.

1979, Discharge estimates in surface-mine areas using channel-geometry techniques: Proceedings, Symposium on Surface-Mine Hydrology, Sedimentology and Reclamation, University of Kentucky Bulletin 119, p. 43-49.

1981, Channel geometry of regulated streams in Kansas as related to mean discharge, 1970-80: Kansas Water Office Technical Report No. 15, 32 p.

1982, Perennial-streamflow characteristics related to channel geometry and sediment in Missouri River Basin: U.S. Geological Survey Professional Paper 1242, 37 p.

Osterkamp, W.R., Hedman, E.R., and Wiseman, A.G., 1982, Geometry, basin characteristics, discharge, and particle-size data from gaged stream-channel sites, western United States: U.S. Geological Survey Hydrologic Data, Open-File Report 82-93, 56 p.

Osterkamp, W.R., McNellis, J.M., and Jordan, P.R., 1978, Guidelines for the use of structural versus regression analysis in geomorphic studies: U.S. Geological Survey Water-Resources Investigations Report 78-135, 22 p.

Osterkamp, W.R., and Wiseman, A.G., 1980, Particlesize analyses of bed and bank material from channels of the Missouri River Basin: U.S. Geological Survey Hydrologic Data, Open-File Report 80-429, 31 p.

Pabst, B.J., 1988, January 1988 water levels, and data related to water-level changes, western and southcentral Kansas: U.S. Geological Survey Open-File Report 88-342, 158 p.

1991, Percentage change in saturated thickness of the High Plains aquifer, west-central Kansas, 1950 to average 1988-90: U.S. Geological Survey WaterResources Investigations Report 91-4008, 1 sheet, scale $1: 125,000$. 
Pabst, M.E., 1977a, January 1977 water levels and data related to water-level changes since 1950 , western Kansas: U.S. Geological Survey Open-File Report 77-264, 209 p.

1977b, Map showing percentage decline in saturated thickness of unconsolidated aquifer, 1950-77, westcentral Kansas: U.S. Geological Survey Open-File Report 77-675, 1 sheet, scale 1:126,720.

1978a, January 1978 water levels, and data related to water-level changes since 1940 or 1950 , western Kansas: U.S. Geological Survey Open-File Report 78-409, 179 p.

1978b, Map showing percentage decrease in saturated thickness of unconsolidated aquifer, 1950-78, west-central Kansas: U.S. Geological Survey OpenFile Report 78-874, 1 sheet, scale 1:126,720.

$1978 c$, Map showing saturated thickness of unconsolidated aquifer, southwestern Kansas, January 1978: U.S. Geological Survey Open-File Report 78-969, 4 sheets, scale 1:125,000.

1979a, January 1979 water levels and data related to water-level changes, western and southcentral Kansas: U.S. Geological Survey Open-File Report 79-925, $213 \mathrm{p}$.

1979b, Maps showing saturated thickness, January 1979, and percentage decrease in saturated thickness, 1950-79, of unconsolidated aquifer, westcentral Kansas: U.S. Geological Survey Open-File Report 79-1340, 2 sheets, scale 1:125,000.

1980, January 1980 water levels and data related to water-level changes, western and south-central Kansas: U.S. Geological Survey Hydrologic Data, Open-File Report 80-958, 166 p.

1981, January 1981 water levels and data related to water-level changes, western and south-central Kansas: U.S. Geological Survey Open-File Report 81-1001, 168 p.

1982a, January 1982 water levels and data related to water-level changes, western and south-central Kansas: U.S. Geological Survey Open-File Report 82-649, 167 p.

1982b, Map showing percentage change in saturated thickness of the High Plains aquifer, west-central Kansas, 1950 to average 1980-82: U.S. Geological Survey Open-File Report 82-1010, 1 sheet, scale $1: 125,000$.

1983a, January 1983 water levels and data related to water-level changes, western and south-central Kansas: U.S. Geological Survey Open-File Report 83-762, $164 \mathrm{p}$.

1983b, Kansas ground-water observation-well network, 1983: U.S. Geological Survey Open-File Report 83-528, $57 \mathrm{p}$.
Pabst, M.E., and Dague, B.J., 1984a, January 1984 water levels and data related to water-level changes in western and south-central Kansas: U.S. Geological Survey Open-File Report 84-613, 162 p.

$1984 \mathrm{~b}$, Percentage change in saturated thickness of the High Plains aquifer, west-central Kansas, 1950 to average 1982-84: U.S. Geological Survey WaterResources Investigations Report 84-4357, 1 sheet, scale 1:125,000.

Pabst, M.E., and Gutentag, E.D., 1977, Water-level changes in west-central Kansas, 1950-77: Kansas Geological Survey Journal, October 1977, 18 p.

1979, Water-level changes in southwestern Kansas, 1940-78: Kansas Geological Survey Journal, May $1979,29 \mathrm{p}$.

*Pabst, M.E., and Jenkins, E.D., 1973, Water-level changes in northwestern Kansas, 1950-73: Kansas Geological Survey Journal, October 1973, 14 p.

*__ 1974, Water-level changes in west-central Kansas, 1950-74: Kansas Geological Survey Journal, October 1974, 15 p.

1976a, Water-level changes in northwestern Kansas, 1950-76: Kansas Geological Survey Journal, December 1976, $20 \mathrm{p}$.

*__ 1976b, Water-level changes in southwestern Kansas, 1940-75: Kansas Geological Survey Journal, May 1976, $26 \mathrm{p}$.

Pabst, M.E., and Stullken, L.E., 1981, Altitude and configuration of the water table in the the High Plains aquifer in Kansas, 1980: U.S. Geological Survey Water-Resource Investigations 85-4009, 1 sheet, scale $1: 500,000$.

1982, Altitude and configuration of the water table in the High Plains aquifer of Kansas, pre-1950: U.S. Geological Survey Open-File Report 82-117, 1 sheet, scale 1:500,000.

1985, Altitude and configuration of the water table in the High Plains aquifer in Kansas, 1970: U.S. Geological Survey Open-File Report 82-448, 1 sheet, scale 1:500,000.

1986, Altitude and configuration of the water table in the High Plains aquifer in Kansas, 1960: U.S.

Geological Survey Open-File Report 82-429, 1 sheet, scale 1:500,000.

1987, Altitude and configuration of the water table in the High Plains aquifer in Kansas, 1965: U.S. Geological Survey Open-File Report 82-449, 1 sheet, scale 1:500,000.

*Parker, H.N., 1911, Quality of the water supplies of Kansas, with a preliminary report on Stream pollution by mine waters in southeastern Kansas, by E.H.S. Bailey: U.S. Geological Survey Water-Supply Paper 273, $375 \mathrm{p}$. 
*Peale, A.C., 1886, Lists and analyses of the mineral springs of the United States (a preliminary study): U.S. Geological Survey Bulletin 32, 235 p.

$*$ 1894, Natural mineral waters of the United States: U.S. Geological Survey 14th Annual Report, Part II-B, p. 49-88.

Pearl, R.H., Roberts, R.S., Keene, K.M., and McClain, T.J., 1972, Water resources of northwestern Kansas: U.S. Geological Survey Hydrologic Investigations Atlas HA-429, 2 sheets, scale 1:250,000.

Peek, C.O., and Jordan, P.R., 1978, Determination of peak discharge from rainfall data for urbanized basins, Wichita, Kansas: U.S. Geological Survey Open-File Report 78-974, 49 p.

Perry, C.A., 1980, Preliminary analysis of regionalprecipitation periodicity: U.S. Geological Survey Water-Resources Investigations Report 80-74, 26 p.

1981, Regional precipitation periodicity, in Proceedings of Fourth Conference on Hydrometeorology, Reno, Nev., October 7-9, 1981: American Meteorological Society, session 1B, p. 45-50.

1984a, A method of estimating flood volumes in western Kansas: U.S. Geological Survey WaterResources Investigations Report 84-4164, 18 p.

1984b, Natural ground-water-recharge data from three selected sites in Harvey County, south-central Kansas: U.S. Geological Survey Open-File Report 84-457, $31 \mathrm{p}$.

1987, Solar-activity harmonics and world climate [abs.]: EOS, Transactions of the American Geophysical Union, v. 68, no. 44, November 3, 1987, p. 1269.

1989, A solar chronometer for climate-Astronomical and geophysical evidence: Lawrence, University of Kansas, Ph.D. dissertation, 314 p.

1990a, A solar-luminosity model and climate, in Schatten, K.H., and Arking, Albert, eds., Climate impact of solar variability: National Aeronautics and Space Administration, NASA Conference Publication 3086, p. 181-188.

$1990 \mathrm{~b}$, Source, extent, and degradation of herbicides in a shallow aquifer near Hesston, Kansas: U.S. Geological Survey Water-Resources Investigations Report 90-4019, $24 \mathrm{p}$.

1990c, Speculation on a solar chronometer for climate, in Schatten, K.H., and Arking, Albert, eds., Climate impact of solar variability: National Aeronautics and Space Administration, NASA Conference Publication 3086, p. 357-364.

1991a, A Pleistocene/Holocene climatic model [abs.]: Symposia, Institute for Tertiary-Quaternary Studies, University of Kansas, Lawrence, Kans., February 28-March 1, 1991, unnumbered page. 1991b, A solar-luminosity/oceanic/atmospheric mechanism for regional climate: National Science Foundation, Workshop on Solar-Terrestrial Impacts on Global Change, Boulder, Colo., May 8-10, 1991, unnumbered page.

1991c, Annual precipitation estimates-1 to 4 years in advance [abs.], in Program of Federal Forecasters Conference/1991, Washington, D.C., September 12, 1991: U.S. Department of Agriculture, p. 13.

1991d, Future water availability [abs.]: Proceedings of 8th Annual Water and the Future of Kansas-Water in Conflict, Manhattan, Kans., March 4-5, 1991, p. 42.

1991e, Observed and simulated distribution of selected herbicides in silty loam, sandy loam, and clay soil profiles near Topeka, Kansas, 1986-88: U.S. Geological Survey Water-Resources Investigations Report 91-4017, 61 p.

1991f, Recent precipitation patterns in the United States as related to solar-irradiance variations [abs.]: AGU Program and Abstracts, 1991 Fall Meeting, December 9-13, 1991, p. 69.

$1991 \mathrm{~g}$, Some guidelines for onsite studies of pesticide leaching in the unsaturated and saturated zones: U.S. Geological Survey Water-Resources Investigations Report 91-4075, 38 p.

1992a, A correlation between precipitation in the western United States and solar irradiance variations: American Water Resources Association, Proceedings of 28th Annual Conference \& Symposium on Managing Water Resources During Global Change, Reno, Nev., November 1-5, 1992, p. 721-729.

1992b, Annual precipitation estimates -1 to 4 years in advance, in Papers and Proceedings of Federal Forecasters Conference/1991: Washington, D.C., September 12, 1991, p. 134-135.

1992c, The future of rainfall in Kansas [abs.]: Proceedings of 9th Annual Water and the Future of Kansas Conference, Manhattan, Kans., March 4-5, 1992, p. 36.

1993a, A mechanism for the link between solarirradiance variations and regional precipitation, in Redmond, K.T., and Tharp, V.L., eds., Proceedings of the Ninth Annual Pacific Climate (PACLIM) Workshop, Asilomar, Calif., April 21-24, 1992: California Department of Water Resources, Interagency Ecological Studies Program, Technical Report 34, p. 97-102.

1993b, A solar-weather mechanism: World Meteorological Organization Bulletin, v. 42, no. 2, p. 123-I 29. 
1994a, Effects of reservoirs on flood discharges in the Kansas and the Missouri River Basins, 1993-Floods in the upper Mississippi River Basin, 1993: U.S. Geological Survey Circular 1120-E, 20 p.

1994b, Solar-irradiance variations and regional precipitation fluctuations in the western USA: International Journal of Climatology, v. 14, November 1994, p. 969-983.

Perry, C.A., and Anderson, M.R., 1991, Statistical comparison of selected chemical constituents in water from chemigation and conventional irrigation wells in Kansas, 1987: U.S. Geological Survey WaterResources Investigations Report 91-4049, 1 sheet.

Perry, C.A., and Barnes, P.L., 1990, A comparison of concentrations and mass of herbicides in runoff from test plots using conventional and minimum-tillage practices, Kansas River Valley, in Abstracts of the AGU Fall Meeting, December 3-7, 1990, San Francisco, Calif.: EOS, Transactions of the American Geophysical Union, v. 71, no. 43, October 23, 1990, p. 1331.

Perry, C.A., and Hart, R.J., 1984, Flood-frequency estimates for five gaged basins in Wichita, Kansas: U.S. Geological Survey Water-Resources Investigations Report 84-4038, 23 p.

1985, Installation of observation wells on hazardouswaste sites in Kansas using a hollow-stem auger: Ground Water Monitoring Review, Fall 1985, v. 5, no. 4 , p. $70-73$.

Perry, C.A., and others, 1993, Detection of fractures in Ash Meadows, southwestern Nevada by electromagnetic terrain-conductivity measurements, in Proceedings SPIE-The International Society for Optical Engineering, Ground Sensing, Orlando, Fla., April 14, 1993, v. 1941, p. 113-124.

Perry, C.A., Robbins, Victor, and Barnes, P.L., 1988, Factors affecting leaching in agricultural areas and an assessment of agricultural chemicals in the ground water of Kansas: U.S. Geological Survey WaterResources Investigations Report 88-4104, 55 p.

Perry, C.A., and Studley, S.E., 1994, Effect of flood control reservoirs on peak discharges along the Kansas River, 1993 [abs.]: EOS, Transactions of the American Geophysical Union, v. 74, no. 43, p. 61.

Perry, C.A., and Thurman, E.M., 1989, Experimental surface-water sampling device for agricultural fieldrunoff investigations, in Pederson, G.L., and Smith, M.M., compilers, U.S. Geological Survey Second National Symposium on Water Quality-Abstracts of the Technical Sessions, Orlando, Fla., November 12-17, 1989: U.S. Geological Survey Open-File Report 89-409, p. 72.
*Petri, L.R., Lane, C.W., and Furness, L.W., 1964, Water resources of the Wichita area, Kansas: U.S. Geological Survey Water-Supply Paper 1499-I, 69 p.

Plummer, L.N., Michel, R.L., Thurman, E.M., and Glynn, P.D., 1993, Environmental tracers for age dating young ground water, in Alley, W.M., ed., Regional ground-water quality: New York, Van Nostrand Reinhold, p. 255-294.

Pomes, M.L., Holub, D.G., Aga, D.S., and Thurman, E.M., 1993a, Isocratic separation of alachlor ethanesulfonic acid, alachlor oxoacetic acid, and hydroxyatrazine by reversed-phase liquid chromatography, in Morganwalp, D.W., and Aronson, D.A., compilers, U.S. Geological Survey Toxic Substances Hydrology Program-Abstracts of the Technical Meeting, Colorado Springs, Colo., September 20-24, 1993: U.S. Geological Survey Open-File Report 93-454, p. 81 .

1993b, Isocratic separation of alachlor ethanesulfonic acid, alachlor oxoacetic acid, and hydroxyatrazine by reversed-phase liquid chromatography [abs.], in Programs and proceedings of symposium on agricultural nonpoint sources of contaminants-Focus on herbicides, Lawrence, Kans., September 28-29, 1993: U.S. Environmental Protection Agency, Region VII, and U.S. Geological Survey, p. 37.

Pomes, M.L., and Thurman, E.M., 1990, Comparison of microtitre-plate immunoassay (ELISA) and gas chromatography/mass spectrometry (GC/MS) for analysis of herbicides in stormflow samples, in Abstracts of AGU Fall Meeting, December 3-7, 1990, San Francisco, Calif.: EOS, Transactions of the American Geophysi-cal Union, v. 71, no. 43, October 23, 1990, p. 1331.

1991, Comparison of microtitre-plate immunoassay (ELISA) and gas chromatography/mass spectrometry (GC/MS) for analysis of herbicides in storm runoff samples [abs.]: Proceedings of 8th Annual Water and the Future of Kansas-Water in Conflict, March 4-5, 1991, p. 43.

Pomes, M.L., Thurman, E.M., and Goolsby, D.A., 1991a, Comparison of microtitre-plate, enzyme-linked immunosorbent assay (ELISA) and gas chromatography/mass spectrometry (GC/MS) for analysis of herbicides in storm-runoff samples, in Mallard, G.E., and Aronson, D.A., compilers, Abstracts of the Technical Meeting, U.S. Geological Survey Toxic Substances Hydrology Program, Monterey, Calif., March 11-15, 1991: U.S. Geological Survey Open-File Report 91-88, p. 108. 
1991b, Comparison of microtitre-plate, enzyme-

linked immunosorbent assay (ELISA) and gas chromatography/mass spectrometry (GC/MS) for analysis of herbicides in storm-runoff samples, in Mallard, G.E., and Aronson, D.A., eds., U.S. Geological Survey Toxic Substances Hydrology Program-Proceedings of the Technical Meeting, Monterey, Calif., March 11-15, 1991: U.S.

Geological Survey Water-Resources Investigations Report 91-4034, p. 572-575.

Pomes, M.L., Thurman, E.M., and Tate, C.M., 1991, Variation of dissolved-organic-carbon concentrations in soil waters from a tall-grass prairie and galley-forest watershed, northeast Kansas: AGU Program and Abstracts, 1991 Fall Meeting, December 9-13, 1991, p. 205-206.

Pope, L.M., Arruda, J.A., and Fromm, C.H., 1988, Relation of trihalomethane-formation potential to water-quality and physical characteristics of small water-supply lakes, eastern Kansas: U.S. Geological Survey Water-Resources Investigations Report 88-4161, 46 p.

Pope, L.M., Arruda, J.A., and Vahsholtz, A.E., 1985, Water-quality reconnaissance of selected water-supply lakes in eastern Kansas: U.S. Geological Survey Water-Resources Investigations Report 85-4058, 47 p.

Pope, L.M., and Bevans, H.E., 1984, Relation of urban land-use and dry-weather, storm, and snowmelt flow characteristics to stream-water quality, Shunganunga Creek Basin, Topeka, Kansas: U.S. Geological Survey Open-File Report 84-750, 64 p.

1987, Relation of urban land-use and dry-weather, storm, and snowmelt flow characteristics to streamwater quality, Shunganunga Creek Basin, Topeka, Kansas: U.S. Geological Survey Water-Supply Paper 2283, $39 \mathrm{p}$.

Pope, L.M., and Diaz, A.M., 1982, Quality-of-water data and statistical summary for selected coal-mine strip pits in Crawford and Cherokee Counties, southeastern Kansas: U.S. Geological Survey Open-File Report 82-1021, 28 p.

Pope, L.M., Diaz, A.M., and Butler, M.K., 1983, Urban water-quality data and statistical summaries for selected sites in the Shunganunga Creek Basin, Topeka, Kansas: Kansas Department of Health and Environment Bulletin B2-49, 203 p.

Pope, L.M., and Hess, L.G., 1989, Load-detention efficiencies in a dry-pond basin, in Roesner, L.A., Urbonas, Ben, and Sonnen, M.B., eds., Design of urban runoff quality controls: Proceedings of Engineering Foundation Conference on Current Practice and Design Criteria for Urban Quality Control, Potosi, Mo., July 10-15, 1988, p. 258-267.
Pope, L.M., Jennings, M.E., and Thibodeaux, K.G., 1988, Instrumentation for a dry-pond detention study, in Proceedings of 1988 National Conference on Hydraulic Engineering: American Society of Civil Engineers, Colorado Springs, Colo., August 8-12, 1988, p. 84-89.

Powell, K.A., 1994, Water-resources activities of the U.S. Geological Survey in Kansas-Fiscal years 1992 and 1993, and plans for fiscal year 1994: U.S. Geological Survey Open-File Report 94-89, 122 p.

Prescott, G.C., Jr., 1948, Preliminary report on the groundwater resources of Labette County, Kansas: Kansas Geological Survey Open-File Report 48-7, 15 p.

*___ 1951, Geology and ground-water resources of Lane County, Kansas: Kansas Geological Survey Bulletin 93, $126 \mathrm{p}$.

1953a, Geology and ground-water resources of Cheyenne County, Kansas: Kansas Geological Survey Bulletin 100, $106 \mathrm{p}$.

1953b, Geology and ground-water resources of Sherman County, Kansas: Kansas Geological Survey Bulletin 105, $130 \mathrm{p}$.

1955, Geology and ground-water resources of Graham County, Kansas: Kansas Geological Survey Bulletin 110, 98 p.

Prescott, G.C., Jr., Branch, J.R., and Wilson, W.W., 1954, Geology and ground-water resources of Wichita and Greeley Counties, Kansas: Kansas Geological Survey Bulletin 108, $134 \mathrm{p}$.

Prill, R.C., 1968, Movement of moisture in the unsaturated zone in a dune area, southwestern Kansas, in Geological Survey Research, 1968, Chapter D: U.S. Geological Survey Professional Paper 600-D, p. D1-D9.

1977, Movement of moisture in the unsaturated zone in a loess-mantled area, southwestern Kansas: U.S. Geological Survey Professional Paper 1021, 21 p.

*Prill, R.C., and Meyer, W.R., 1968, Neutron moisture measurements by continuous- and point-logging procedures, in Geological Survey Research, 1968, Chapter B: U.S. Geological Survey Professional Paper 600-B, p. B226-B230.

*Prosser, C.S., and Beede, J.W., 1904, Description of Cottonwood Falls quadrangle, Kansas: U.S. Geological Survey Geologic Atlas, Folio 109, 6 p., 2 pls.

Rasmussen, P.P., 1994, The hydrogeology and the groundwater quality conditions at the City of Olathe Landfill: Lawrence, University of Kansas, master's thesis, $90 \mathrm{p}$.

Rasmussen, P.P., Shockley, J.C., and Hargadine, D.A., 1994, Hydrogeology and water-quality conditions at the City of Olathe Landfill, east-central Kansas, 1990-93: U.S. Geological Survey Water-Resources Investigations Report 94 4166, 44 p. 
Reed, T.B., 1981, Map of water table in Solomon River Valley, Waconda Lake to Solomon, north-central Kansas, May 1980: U.S. Geological Survey WaterResources Investigations, Open-File Report 81-334, 1 sheet, scale 1:125,000.

Reed, T.B., and Burnett, R.D., 1985, Compilation and analyses of aquifer-performance tests in eastern Kansas: U.S. Geological Survey Open-File Report 85-200, 125 p.

*Rice, R.C., 1920, Surface waters of Kansas, 1895-1919: Kansas Water Commission, 463 p.

Richards, D.B., and Dunaway, T.W., 1972, Geohydrologic data for numerical modeling of ground-water withdrawals in the Little Arkansas River Basin area, southcentral Kansas: U.S. Geological Survey Open-File Report, 426 p.

Roberts, R.S., and Hodson, W.G., 1966, Ground water in Kansas-Bibliography and subject index: Kansas Geological Survey Bulletin 182, 41 p.

*Ropes, L.H., Morgan, C.O., and McNellis, J.M., 1969, FORTRAN IV program for synthesis and plotting of water-quality data: Kansas Geological Survey Special Distribution Publication 39, 59 p.

Rosenshein, J.S., 1979, Groundwater in the United States 1975-78: American Geophysical Union, Reviews of Geophysics and Space Physics, v. 17, no. 6, September 1979, p. 1240-1253.

1988, Region 18, Alluvial valleys, in Back, William, Rosenshein, J.S., and Seaber, P.R., eds., Hydrogeology: Boulder, Colo., Geological Survey of America, The Geology of North America, v. 0-2, p. 165-175.

Rosenshein, J.S., and Bennett, G.D., eds., 1984, Groundwater hydraulics: American Geophysical Union, Water Resources Monograph 9, 407 p.

Rosenshein, J.S., Moore, J.E., Lohman, S.W., and Chase, E.B., eds., 1986, Two hundred years of hydrogeology in the United States: U.S. Geological Survey OpenFile Report 86-480, 110 p.

Rutledge, A.T., 1988, An axisymmetric model to simulate drawdown within and around pumping well [abs.], in Program of International Conference on Advances in Ground-Water Hydrology: American Institute of Hydrology, Tampa, Fla., November 16-19, 1988, p. 15.

1991, An axisymmetric finite-difference flow model to simulate drawdown in and around a pumped well: U.S. Geological Survey Water-Resources Investigations Report 90-4098, 33 p.
Rutledge, A.T., and Helgesen, J.O., 1989a, Transport of chloride and atrazine through the unsaturated zone beneath two irrigated fields in south-central Kansas, in Pederson, G.L., and Smith, M.M., compilers, U.S. Geological Survey Second National Symposium on Water Quality - Abstracts of the Technical Sessions, Orlando, Fla., November 12-17, 1989: U.S. Geological Survey Open-File Report 88-409, p. 81.

$1989 \mathrm{~b}$, Use of a simplified transport model for pesticides in the unsaturated zone, in Mallard, G.E., and Ragone, S.E., eds., U.S. Geological Survey Toxic Substances Hydrology Program-Proceedings of the Technical Meeting, Phoenix, Ariz., September 26-30, 1988: U.S. Geological Survey Water-Resources Investigations Report 88-4220, p. 523-530.

1990, Characterization of ground-water flow and chemical transport beneath two irrigated fields in south-central Kansas, 1988: U.S. Geological Survey Water-Resources Investigations Report 90-4065, 37 p.

1991, Steady-state unsaturated-zone model to simulate pesticide transport: U.S. Geological Survey Water-Resources Investigations Report 90-4164, 13 p.

*Schrader, F.C., 1908, Description of the Independence quadrangle, Kansas: U.S. Geological Survey Geologic Atlas, Folio 159,7 p., 3 pls.

*Schrader, F.C., and Haworth, Erasmus, 1906, Economic geology of the Independence quadrangle, Kansas: U.S. Geological Survey Bulletin 296, 74 p.

Schumm, S.A., and Lichty, R.W., 1961, Recent flood-plain formation along the Cimarron River in Kansas: U.S. Geological Survey Professional Paper 424-B, p. B112.

* ___ 1963, Channel widening and flood-plain construction along the Cimarron River in southwestern Kansas: U.S. Geological Survey Professional Paper 352-D, p. 71-88.

Scribner, E.A., Goolsby, D.A., Thurman, E.M., Meyer, M.T., and Pomes, M.L., 1994, Concentrations of selected herbicides, two triazine metabolites, and nutrients in storm runoff from nine stream basins in the midwestern United States, 1990-92: U.S. Geological Survey Open-File Report 94-396, 144 p.

Scribner, E.A., Thurman, E.M., and Goolsby, D.A., 1993a, Reconnaissance data for selected herbicides and their metabolites in surface water of the midwestern United States-Immunoassay and gas chromatography/mass spectrometry [abs.], in Programs and proceedings of symposium on agricultural nonpoint sources of contaminants-Focus on herbicides, Lawrence, Kans., September 28-29, 1993: U.S. Environmental Protection Agency, Region VII, and U.S. Geological Survey, p. 41. 
1993b, Reconnaissance data for selected herbicides and two metabolites in surface water of the midwestern United States-Chemical analysis by immunoassay and gas chromatography/mass spectrometry, in Morganwalp, D.W., and Aronson, D.A., compilers, U.S. Geological Survey Toxic Substances Hydrology Program-Abstracts of the Technical Meeting, Colorado Springs, Colo., September 20-24, 1993: U.S. Geological Survey Open-File Report 93-454, p. 84 .

Scribner, E.A., Thurman, E.M., Goolsby, D.A., Meyer, M.T., Mills, M.S., and Pomes, M.L., 1993,

Reconnaissance data for selected herbicides, two atrazine metabolites, and nitrate in surface water of the midwestern United States, 1989-90: U.S. Geological Survey Open-File Report 93-457, 77 p.

Seevers, W.J., 1969, Geology and ground-water resources of Linn County, Kansas: Kansas Geological Survey Bulletin 193, 65 p.

Shamet, K.A., 1992, Surfactants in a natural foam-Characterization and role in enhanced degradation of herbicides: Lawrence, University of Kansas, master's thesis, $83 \mathrm{p}$.

Signor, D.C., and Imes, J.L., 1989, Geohydrology of regional aquifer systems in Cretaceous and older rocks underlying the central United States, in Swain, L.A., and Johnson, A.I., eds., Regional Aquifer Systems of the United States-Aquifers of the midwestern area: American Water Resources Association, AWRA Monograph Series No. 13, p. 149-163.

Skougstad, M.W., and others, 1979, Methods for determination of inorganic substances in water and fluvial sediments: U.S. Geological Survey Techniques of Water-Resources Investigations, book 5, chap. A1, $626 \mathrm{p}$.

Slagle, S.E., and Weakly, E.C., 1976, Ground-water resources of Greeley and Wichita Counties, western Kansas: Kansas Geological Survey Irrigation Series 2, $21 \mathrm{p}$.

*Slichter, C.S., 1902, The motions of underground waters: U.S. Geological Survey Water-Supply Paper 67, 106 p.

*__ 1906, The underflow in the Arkansas Valley in western Kansas: U.S. Geological Survey WaterSupply Paper 153, $90 \mathrm{p}$.

*Smith, W.S.T., 1905, Water resources of the Joplin district, Missouri-Kansas: U.S. Geological Survey Water-Supply Paper 145, p. 74-83.

*Smith, W.S.T., and Siebenthal, C.E., 1907, Description of the Joplin district, Missouri-Kansas: U.S. Geological Survey Geologic Atlas, Folio 148, 20 p., 27 figs.
Snipes, R.J., and others, 1974, Floods of June 1965 in Arkansas River Basin, Colorado, Kansas, and New Mexico: U.S. Geological Survey Water-Supply Paper 1850-D, p. D1-D97.

Sophocleous, Marios, and Perry, C.A., 1984, Experimental studies in natural ground-water-recharge dynamics-Assessment of recent advances in instrumentation: Journal of Hydrology, v. 70, p. 369-382.

1985, Experimental studies in natural ground-waterrecharge dynamics-The analysis of observed recharge events: Journal of Hydrology, v. 81, p. 297-332.

1987, Measuring and computing natural groundwater recharge at sites in south-central Kansas: U.S. Geological Survey Water-Resources Investigations Report 87-4097, 48 p.

Spinazola, J.M., 1981, Map of water table in Graham County, northwestern Kansas, March 1979: U.S. Geological Survey Water-Resources Investigations, Open-File Report 81-333, 1 sheet, scale 1:125,000.

1982a, Hydrologic maps of the High Plains aquifer, January 1981, southwestern Kansas: U.S. Geological Survey Water-Resources Investigations Report 82-4079, 8 sheets, scale 1:125,000.

1982b, Hydrologic maps of the Ogallala aquifer, west-central Kansas, 1979-81: U.S. Geological Survey Open-File Report 82-258, 4 sheets, scale 1:125,000.

Spinazola, J.M., and Dealy, M.T., 1983, Hydrology of the Ogallala aquifer in Ford County, southwestern Kansas: U.S. Geological Survey Water-Resources Investigations Report 83-4226, 58 p.

Spinazola, J.M., Gillespie, J.B., and Hart, R.J., 1985, Ground-water flow and solute transport in the Equusbeds area, south-central Kansas, 1940-79: U.S. Geological Survey Water-Resources Investigations Report 85-4336, 68 p.

Spinazola, J.M., Hansen, C.V., Underwood, E.J., Kenny, J.F., and Wolf, R.J., 1987, Index to selected machinereadable geohydrologic data for Precambrian through Cretaceous rocks in Kansas: U.S. Geological Survey Open-File Report 87-396, 31 p.

Spinazola, J.M., Wolf, R.J., and McGovern, H.E., 1992, Geohydrologic systems in Kansas-Physical framework of the Great Plains aquifer system: U.S. Geological Survey Hydrologic Investigations Atlas HA-722-B, 2 sheets, scales $1: 1,000,000$ and $\mathrm{I}: 2,000,000$.

Spruill, T.B., 1982, Nitrate-nitrogen concentrations in ground water from three selected areas in Kansas: U.S. Geological Survey Water-Resources Investigations Report 82-11, 32 p. 
1983a, Relationship of nitrate concentrations to distance of well screen openings below casing water levels: American Water Resources Association, Water Resources Bulletin, v. 19, no. 6, December 1983, p. 977-981.

1983b, Statistical summaries of selected chemical constituents in Kansas ground-water supplies, 1976-81: U.S. Geological Survey Open-File Report 83-263, 29 p.

1984a, Assessment of water resources in leadzinc mined areas in Cherokee County, Kansas, and adjacent areas: U.S. Geological Survey Open-File Report 84-439, 102 p.

1984b, Use of data from regional ground-waterquality monitoring networks: 29th Annual Midwest Ground-Water Conference, Proceedings, Lawrence, Kans., October 1-3, 1984, p. 12.

1985, Statistical evaluation of the effects of irrigation on chemical quality of ground water and base flow in three river valleys in north-central Kansas: U.S. Geological Survey Water-Resources Investigations Report 85-4156, 64 p.

1987a, A proposed method for design of a network to describe non-normally distributed ground-waterquality characteristics [abs.]: EOS, Transactions of the American Geophysical Union, v. 68, no. 16, April 21, 1987, p. 313.

1987b, Assessment of water resources in lead-zinc mined areas in Cherokee County, Kansas, and adjacent areas: U.S. Geological Survey Water-Supply Paper 2268, $68 \mathrm{p}$.

1988, Use of total organic carbon as an indicator of contamination from an oil refinery, south-central Kansas: Ground Water Monitoring Review, Summer 1988, p. 76-82.

1989, Transport of organic contaminants in ground water beneath an abandoned oil refinery, in Pederson, G.L., and Smith, M.M., compilers, U.S. Geological Survey Second National Symposium on Water Quality-Abstracts of the Technical Sessions, Orlando, Fla., November 12-17, 1989: U.S. Geological Survey Open-File Report 89-409, p. 95.

1990a, Monitoring regional ground-water quality-Statistical considerations and description of a monitoring network in Kansas: U.S. Geological Survey Water-Resources Investigations Report 90-4159, 41 p.

$1990 \mathrm{~b}$, Preliminary evaluation of the effects of an abandoned oil refinery on chemical quality of water in the Arkansas River Valley, Arkansas City, Kansas, 1985-86: U.S. Geological Survey Water-Resources Investigations Report 89-4190, 53 p.
Spruill, T.B., and Candela, Lucila, 1990, Two approaches to design of monitoring networks: Ground Water, v. 28, no. 3 , p. $430-442$.

Spruill, T.B., and Kenny, J.F., 1981, Location of sampling sites and available information on wells sampled in the Kansas Ground-Water-Quality Monitoring Network, 1976-80: U.S. Geological Survey Hydrologic Data, Open-File Report 81-925, 49 p.

Squillace, P.J., and Thurman, E.M., 1992, Herbicide transport in rivers-Importance of hydrology and geochemistry in nonpoint-source contamination: Environmental Science and Technology, v. 26, no. 3, p. 538-545.

Squillace, P.J., Thurman, E.M., and Furlong, E.T., 1993, Groundwater as nonpoint source of atrazine and deethylatrazine in a river during base flow conditions: Water Resources Research, v. 29, no. 6, p.1719-1729.

Stamer, J.K., 1991, An investigation summary concerning pesticides in lower Kansas River Basin in Kansas and Nebraska [abs.]: Proceedings of 8th Annual Water and the Future of Kansas-Water in Conflict, March 4-5, 1991, p. 45-46.

1992, Distribution of atrazine in surface water, lower Kansas River Basin, Kansas and Nebraska [abs.]: Proceedings of North Central Weed Science Society, v. 47, p. 148.

Stamer, J.K., Jordan, P.R., Engberg, R.A., and Dugan, J.T., 1987, Surface-water-quality assessment of the lower Kansas River Basin, Kansas and Nebraska-Project description: U.S. Geological Survey Open-File Report 87-105, 36 p.

Stamer, J.K., Pope, L.M., and Zelt, R.B., 1990, Occurrence and distribution of pesticides in the lower Kansas River Basin in Kansas and Nebraska: Proceedings of 7th Annual Water and the Future of Kansas Conference, Manhattan, Kans., March 7-8, 1990, p. 25-26.

Stamer, J.K., and Zelt, R.B., 1990, Occurrence and distribution of pesticides in the inflows and outflows of reservoirs in northeast Kansas: Kansas Academy of Science, Abstracts, v. 9, p. 60.

1991, Areal and temporal distribution of nitrogencontaining herbicides in surface water in the lower Kansas River Basin, Kansas and Nebraska: American Water Resources Association, 27th Annual Conference and Symposium, New Orleans, La., September 8-13, 1991, p. 349-350.

1992, Distribution of atrazine and similar nitrogencontaining herbicides, lower Kansas River Basin: U.S Geological Survey Director's Yearbook 1991, p. 76-79. 
1994, Organonitrogen herbicides in the lower Kansas River Basin: American Water Works Association, v. 86, no. 1, January 1994, p. 93-104.

Stramel, G.J., 1956, Progress report on the ground-water hydrology of the Equus-beds area, Kansas: Kansas Geological Survey Bulletin 119, pt. 1, 59 p.

1957, The hydraulic properties of the Ordovician rocks at Pittsburg, Kansas: Kansas Geological Survey Bulletin 127, pt. 5, p. 153-178.

1966, Progress report on the ground-water hydrology of the Equus-beds area, Kansas, 1966: Kansas Geological Survey Bulletin 187, pt. 2, 27 p.

Stramel, G.J., Lane, C.W., and Hodson, W.G., 1958, Geology and ground-water hydrology of the Ingalls area, Kansas: Kansas Geological Survey Bulletin 132, $154 \mathrm{p}$.

Stullken, L.E., 1980, Hydrogeologic data from northcentral Kansas: Kansas Geological Survey Basic-Data Series, Ground-Water Release 7, 46 p.

1984, Hydrology of Prairie Dog Creek Valley, Norton Dam to state line, north-central Kansas: U.S. Geological Survey Water-Resources Investigations Report 84-4162, $49 \mathrm{p}$.

1988a, Hydrologic maps of the High Plains aquifer, southwestern Kansas, January 1986: U.S. Geological Survey Water-Resources Investigations Report 88-4039, 4 sheets, scale 1:250,000.

$1988 \mathrm{~b}$, Summary of water data for the Janzen recharge investigation, Scott County, Kansas, 1980-86: U.S. Geological Survey Open-File Report 88-83, $38 \mathrm{p}$.

Stullken, L.E., and Fader, S.W., 1976, Hydrogeologic data from the Great Bend Prairie, south-central Kansas:

Kansas Geological Survey Basic-Data Series, GroundWater Release 5, $50 \mathrm{p}$.

Stulken, L.E., and Pabst, M.E., 1981, Altitude and configuration of the water table in High Plains regional aquifer of Kansas, 1975: U.S. Geological Survey Open-File Report 81-144, 1 sheet, scale 1:500,000.

1982, Altitude and configuration of the water table in the High Plains aquifer of Kansas, pre-1950: U.S. Geological Survey Open-File Report 82-117, 1 sheet, scale 1:500,000.

Stullken, L.E., Stamer, J.K., and Carr, J.E., 1987, Reconnaissance of water quality in the High Plains aquifer beneath agricultural lands, south-central Kansas: U.S. Geological Survey Water-Resources Investigations Report 87-4003, 25 p.

Stullken, L.E., Watts, K.R., and Lindgren, R.J., 1985, Geohydrology of the High Plains aquifer, western Kansas: U.S. Geological Survey Water-Resources Investigations Report 85-4198, 86 p.
Stullken, L.E., Weakly, E.C., Gutentag, E.D., and Slagle, S.E., 1974, Hydrogeologic data from Greeley, Wichita, Scott, and Lane Counties, Kansas: Kansas Geological Survey Basic-Data Series, Ground-Water Release 4, $58 \mathrm{p}$.

Tanner, D.Q., Sanzolone, R.F., and Zelt, R.B., 1990, Surface-water-quality assessment of the lower Kansas River Basin, Kansas and Nebraska-Concentrations of major metals and trace elements in streambed sediments, 1987: U.S. Geological Survey Open-File Report 90-581, 73 p.

*Theis, C.V., Burleigh, H.P., and Waite, H.A., 1935 , Ground water in the southern High Plains: U.S. Department of the Interior Memorandum for the Press, October 1935, $4 \mathrm{p}$.

*Thomas, H.E., 1962, The meteorological phenomenon of drought in the Southwest: U.S. Geological Survey Professional Paper 372-A, p. A1-A43.

Thurman, E.M., 1993a, Chemistry, degradation, and transport of triazine metabolites in surface water [abs.], in Proceedings of spring meeting, American Geophysical Union, Mineralogical Society of America, and Geochemical Society, Baltimore, Md., May 24-28, 1993: EOS, Transactions of the American Geophysical Union, April 20, 1993, p. 129.

1993b, Chemistry, degradation, and transport of triazine metabolites in surface water [abs.], in Programs and proceedings of symposium on agricultural nonpoint sources of contaminants-Focus on herbicides, Lawrence, Kans., September 28-29, 1993: U.S. Environmental Protection Agency, Region VII, and U.S. Geological Survey, p. 19.

Thurman, E.M., Goolsby, D.A., Meyer, M.T., and Kolpin, D.W., 1991, Herbicides in surface waters of the midwestern United States-The effect of spring flush: Environmental Science and Technology, October 1991, v. 25, p. 1794-1796.

Thurman, E.M., Goolsby, D.A., Meyer, M.T., Mills, M.S., Pomes, M.L., and Kolpin, D.W., 1992, A reconnaissance study of herbicides and their metabolites in surface water of the midwestern United States using immunoassay and gas chromatography/mass spectrometry: Environmental Science and Technology, v. 26, no. 12, p. 2440-2447.

Thurman, E.M., Meyer, M.T., Pomes, M.L., Mills, M.S., and Brown, D.E., 1990, Enzyme-linked immunosorbent assay compared with gas chromatography/ mass spectrometry for the determination of triazine herbicides in water, in Abstracts of the AGU Fall Meeting, December 3-7, 1990, San Francisco, Calif.: EOS, Transactions of the American Geophysical Union, v. 71, no. 43 , p. 1330. 
Thurman, E.M., Meyer, Michael, and Adams, C.D., 1991a, Analysis of atrazine metabolites by enzymelinked immunosorbent assay and gas chromatography/ mass spectrometry, in Mallard, G.E., and Aronson, D.A., compilers, Abstracts of the Technical Meeting, U.S. Geological Survey Toxic Substances Hydrology Program, Monterey, Calif., March 11-15, 1991: U.S. Geological Survey Open-File Report 91-88, p. 107.

1991b, Analysis of atrazine metabolites by enzymelinked immunosorbent assay and gas chromatography/ mass spectrometry, in Mallard, G.E., and Aronson, D.A., eds., U.S. Geological Survey Toxic Substances Hydrology Program-Proceedings of the Technical Meeting, Monterey, Calif., March 11-15, 1991: U.S. Geological Survey Water-Resources Investigations Report 91-4034, p. 568-571.

Thurman, E.M., Meyer, Michael, Pomes, Michael, Perry, C.A., and Schwab, A.P., 1990, Enzyme-linked immunosorbent assay compared with gas chromatography/mass spectrometry for the determination of triazine herbicides in water: Analytical Chemistry, v. 62 , no. 18 , September 15,1990 , p. 2043-2048.

Thurman, E.M., and Mills, M.S., 1991, Herbicide metabolites as indicators of surface and ground-water interaction: AGU Program and Abstracts, 1991 Fall Meeting, December 9-13, 1991, p. 168.

Thurman, E.M., Mills, M.S., and Meyer, M.T., 1993, Chemistry, degradation, and transport of triazine herbicide metabolites in surface water, in Morganwalp, D.W., and Aronson, D.A., compilers, U.S. Geological Survey Toxic Substances Hydrology Program-Abstracts of the Technical Meeting, Colorado Springs, Colo., September 20-24, 1993: U.S. Geological Survey Open-File Report 93-454, p. 68.

Thurman, E.M., Squillace, P.J., Strzepek, K.M., and Garcia, L., 1988, Intelligent data analyzer-Herbicide transport in the Cedar River, Iowa, in Preprints of Papers presented at the 196th ACS National Meeting: American Chemical Society, Los Angeles, Calif., September 25-30, 1988, v. 28, no. 2, p. 13-15.

Townsend, Margaret, Shaukat, Nadeem, Healey, John, and McClain, Tom, 1989, Kansas water levels and data related to water-level changes: Kansas Geological Survey Ground-Water Series 10, $127 \mathrm{p}$.

Trombley, T.J., and Kenny, J.F., 1992, Water resources on and near Indian lands in northeastern Kansas and southeastern Nebraska-Study description: U.S. Geological Survey Open-File Report 91-468, 19 p.

U.S. Geological Survey, 1952, Kansas-Missouri floods of July 1, 1951, with a section on Fluctuations of groundwater levels, by V.C. Fishel: U.S. Geological Survey Water-Supply Paper 1139, 239 p.
1955, Availability, use, and control of water: Report of the Arkansas-White-Red Basins Inter-Agency Committee, pt. 2, sec. 17, 122 p.

1958, Pumping tests at the Goodyear Tire and Rubber Company, Topeka, Kansas: U.S. Geological Survey Open-File Report, 12 p.

1959, Floods of the Kansas River, Topeka, Kansas, in 1935 and 1951: U.S. Geological Survey Hydrologic Investigations Atlas HA-14, 1 sheet, scale 1:24,000.

1962, Surface water records of Kansas, 1961: U.S. Geological Survey Water-Data Report, 165 p.

1963, Surface water records of Kansas, 1962: U.S. Geological Survey Water-Data Report, $179 \mathrm{p}$.

1964a, Status of water resources investigations in Kansas: U.S. Geological Survey folder.

1964b, Surface water records of Kansas, 1963: U.S. Geological Survey Water-Data Report, 191 p.

1965, Surface water records of Kansas, 1964: U.S. Geological Survey Water-Data Report, 215 p.

1966a, Ground water in the Cimarron River Basin, New Mexico, Colorado, Kansas, and Oklahoma: U.S. Geological Survey Open-File Report, $51 \mathrm{p}$.

1966b, Water quality records in Kansas, 1964: U.S. Geological Survey Water-Data Report, 205 p.

1966c, Water resources data for Kansas-Part 1, Surface water records, 1965: U.S. Geological Survey Water-Data Report, 202 p.

1966d, Water resources investigations in Kansas, 1965: U.S. Geological Survey folder.

1967a, Water resources data for Kansas-Part 1, Surface water records, 1966: U.S. Geological Survey Water-Data Report, 202 p.

1967b, Water resources data for Kansas-Part 2, Water quality records, 1965: U.S. Geological Survey Water-Data Report, 223 p.

1968a, Water resources data for Kansas-Part 1, Surface water records, 1967: U.S. Geological Survey Water-Data Report, 204 p.

1968b, Water resources data for Kansas--Part 2, Water quality records, 1966: U.S. Geological Survey Water-Data Report, 223 p.

1969a, Water resources data for Kansas-Part 1, Surface water records, 1968: U.S. Geological Survey Water-Data Report, 212 p.

1969b, Water resources investigations in Kansas, 1968: U.S. Geological Survey folder.

1970a, Water resources data for Kansas-Part 1, Surface water records, 1969: U.S. Geological Survey Water-Data Report, 216 p.

1970b, Water resources data for Kansas-Part 2 , Water quality records, 1967: U.S. Geological Survey Water-Data Report, 191 p. 
1970c, Water resources data for Kansas-Part 2, Water quality records, 1968: U.S. Geological Survey Water-Data Report, 225 p.

1971a, Water resources data for Kansas-Part 1, Surface water records, 1970: U.S. Geological Survey Water-Data Report, 216 p.

1971b, Water resources data for Kansas-Part 2, Water quality records, 1969: U.S. Geological Survey Water-Data Report, 201 p.

1971c, Water resources data for Kansas-Part 2, Water quality records, 1970: U.S. Geological Survey Water-Data Report, $159 \mathrm{p}$.

1972a, Water resources data for Kansas-Part 1, Surface water records, 1971: U.S. Geological Survey Water-Data Report, 206 p.

1972b, Water resources data for Kansas-Part 2, Water quality records, 1971: U.S. Geological Survey Water-Data Report, $140 \mathrm{p}$.

1972c, Water resources investigations in Kansas, 1972: U.S. Geological Survey folder.

1973a, Water resources data for Kansas-Part 1, Surface water records, 1972: U.S. Geological Survey Water-Data Report, 202 p.

1973b, Water resources data for Kansas-Part 2, Water quality records, 1972: U.S. Geological Survey Water-Data Report, 154 p.

1974a, Water resources data for Kansas-Part 1, Surface water records, 1973: U.S. Geological Survey Water-Data Report, 202 p.

1974b, Water resources data for Kansas-Part 2, Water quality records, 1973: U.S. Geological Survey Water-Data Report, 168 p.

1975a, Water resources data for Kansas-Part 1, Surface water records, 1974: U.S. Geological Survey Water-Data Report, 202 p.

1975b, Water resources data for Kansas-Part 2 , Water quality records, 1974: U.S. Geological Survey Water-Data Report, 188 p.

1976, Water resources data for Kansas, water year 1975: U.S. Geological Survey Water-Data Report KS-75-1, $405 \mathrm{p}$

1977, Water resources data for Kansas, water year

1976: U.S. Geological Survey Water-Data Report KS-76-1, 395 p.

1978a, Water resources data for Kansas, water year 1977: U.S. Geological Survey Water-Data Report KS-77-1, 618 p

1978b, Water resources investigations in Kansas:

U.S. Geological Survey folder.

1978c, Water resources investigations in Kansas, fiscal year 1977: U.S. Geological Survey, Kansas District, $80 \mathrm{p}$. 1978d, Water resources investigations in Kansas, 1978: U.S. Geological Survey Water Index folder.

1979, Water resources data for Kansas, water year 1978: U.S. Geological Survey Water-Data Report KS-78-1, 656 p.

1980a, Water resources data for Kansas, water year 1979_-Volume 1. Missouri River Basin: U.S. Geological Survey Water-Data Report KS-79-1, $372 \mathrm{p}$.

$1980 b$, Water resources data for Kansas, water year 1979-Volume 2. Arkansas River Basin: U.S. Geological Survey Water-Data Report KS-79-2, $372 \mathrm{p}$.

1981a, Water resources data for Kansas, water year 1980-Volume 1. Missouri River Basin: U.S. Geological Survey Water-Data Report KS-80-1, $422 \mathrm{p}$.

$1981 \mathrm{~b}$, Water resources data for Kansas, water year 1980-Volume 2. Arkansas River Basin: U.S. Geological Survey Water-Data Report KS-80-2, $340 \mathrm{p}$.

1982, Water resources data for Kansas, water year 1981: U.S. Geological Survey Water-Data Report KS-81-1, 566 p.

1985, The National Gazetteer of the United States of America-Kansas 1984, prepared by the U.S. Geological Survey in cooperation with the U.S. Board on Geographic Names: U.S. Geological Survey Professional Paper $1200-\mathrm{KS}, 326 \mathrm{p}$.

*Waite, H.A., 1942, Geology and ground-water resources of Ford County, Kansas: Kansas Geological Survey Bulletin 43, $250 \mathrm{p}$.

*__ 1947, Geology and ground-water resources of Scott County, Kansas: Kansas Geological Survey Bulletin 66, $216 \mathrm{p}$.

Walters, K.L., 1953, Geology and ground-water resources of Jackson County, Kansas: Kansas Geological Survey Bulletin 101, $91 \mathrm{p}$.

1954, Geology and ground-water resources of Marshall County, Kansas: Kansas Geological Survey Bulletin 106, $116 \mathrm{p}$.

1956, Geology and ground-water resources of Rawlins County, Kansas: Kansas Geological Survey Bulletin 117, $100 \mathrm{p}$.

1961, Geology and ground-water resources of Sumner County, Kansas: Kansas Geological Survey Bulletin 151, $198 \mathrm{p}$.

Walters, K.L., and Bayne, C.K., 1959, Geology and ground-water resources of Clay County, Kansas: Kansas Geological Survey Bulletin 136, 106 p. 
Ward, J.R., 1971, Geohydrology of Atchison County, northeastern Kansas: U.S. Geological Survey OpenFile Report, 22 p.

1973, Geohydrology of Atchison County, northeastern Kansas: U.S. Geological Survey Hydrologic Investigations Atlas HA-467, 2 sheets, scale 1:62,500.

1974, Geohydrology of Nemaha County, northeastern Kansas: Kansas Geological Survey Ground-Water Series 2, $19 \mathrm{p}$.

Ward, P.E., and Leonard, A.R., 1961, Hypothetical circulation of ground water around salt springs in western Oklahoma, Texas, and Kansas: U.S. Geological Survey Professional Paper 424-D, p. D150.

Waterman, W.D., 1952, Geology and hydrology of the Kanopolis Unit in Ellsworth, McPherson, and Saline Counties, Kansas, with a section on The chemical quality of the water, by R.A. Krieger: Kansas Geological Survey Open-File Report ND-27, 186 p.

Watts, K.R., 1985, Potential hydrologic effects of groundwater withdrawals from the Dakota aquifer, southwestern Kansas: U.S. Geological Survey WaterSupply Paper 2304, 72 p.

Watts, K.R., and Stullken, L.E., 1985, Generalized configuration of the base of the High Plains aquifer in Kansas: U.S. Geological Survey Open-File Report 81-344, 1 sheet, scale 1:500,000.

Weeks, J.B., Gutentag, E.D., Heimes, F.J., and Luckey, R.R., 1988, Summary of the High Plains regional aquifer-system analysis in parts of Colorado, Kansas, Nebraska, New Mexico, Oklahoma, South Dakota, Texas, and Wyoming: U.S. Geological Survey Professional Paper 1400-A, $30 \mathrm{p}$.

*Williams, C.C., 1944, Ground-water conditions in the Neosho River Valley in the vicinity of Parsons, Kansas: Kansas Geological Survey Bulletin 52, pt. 2, p. 29-80.

*__ 1946, Ground-water conditions in Arkansas River Valley in the vicinity of Hutchinson, Kansas: Kansas Geological Survey Bulletin 64, pt. 5, p. 145-216.

*__ 1948, Contamination of deep water wells in southeastern Kansas: Kansas Geological Survey Bulletin 76, pt. 2, p. 13-28.

*Williams, C.C., and Bayne, C.K., 1946, Ground-water conditions in Elm Creek Valley, Barber County, Kansas: Kansas Geological Survey Bulletin 64, pt. 3, p. $77-124$.

Williams, C.C., and Lohman, S.W., 1947, Methods used in estimating the ground water supply in the Wichita, Kansas well-field area: EOS, Transactions of the American Geophysical Union, v. 28, no. 1, p. 120-131.
*__ 1949, Geology and ground-water resources of a part of south-central Kansas, with specific references to the Wichita municipal water supply: Kansas Geological Survey Bulletin 79, $455 \mathrm{p}$.

Winslow, J.D., 1972, Geohydrology of Jefferson County, northeastern Kansas: Kansas Geological Survey Bulletin 202, pt. 4, 20 p.

Winslow, J.D., McGovern, H.E., and Mackey, H.L., 1968, Water-level changes in Grant and Stanton Counties, Kansas, 1939-1968: Kansas Geological Survey Special Distribution Publication 37, 17 p.

Winslow, J.D., and Nuzman, C.E., 1966, Electronic simulation of ground-water hydrology in the Kansas River Valley near Topeka, Kansas: Kansas Geological Survey Special Distribution Publication 29, 24 p

Winslow, J.D., Nuzman, C.E., and Fader, S.W., 1964, Water-level changes in Grant and Stanton Counties, 1939-1964: Kansas Geological Survey Special Distribution Publication 10,11 p.

Wolf, R.J., Hansen, C.V., McGovern, H.E., and Spinazola, J.M., 1990, Geohydrologic systems in Kansas with emphasis on systems in upper Cambrian through Lower Cretaceous rocks: U.S. Geological Survey Hydrologic Investigations Atlas HA-722-A, 2 sheets, scales 1:1,500,000 and 1:2,000,000.

Wolf, R.J., and Helgesen, J.O., 1993, Ground- and surface-water interaction between the Kansas River and associated alluvial aquifer, northeastern Kansas: U.S. Geological Survey Water-Resources Investigations Report 92-4137, 49 p.

Wolf, R.J., McGovern, H.E., and Spinazola, J.M., 1992 , Geohydrologic systems in Kansas--Physical framework of the Western Interior Plains confining system: U.S. Geological Survey Hydrologic Investigations Atlas HA-722-C, 2 sheets, scales 1:1,000,000 and $1: 3,000,000$

*Wolff, H.C., 1911, The utilization of the underflow near St. Francis, Kansas: U.S. Geological Survey WaterSupply Paper 258, p. 98-119.

Wolock, D.M., 1993a, Effects of topography and subbasin size on simulated flow pathways in Sleepers River watershed, Vermont [abs.]: EOS, Transactions of the American Geophysical Union, v. 74, no. 43, unnumbered page.

1993b, Simulating the variable-source-area concept of streamflow generation with the watershed model TOPMODEL: U.S. Geological Survey WaterResources Investigations Report 93-4124, 33 p.

1993c, TOPMODEL, a topographic-based watershed model, in Burton, J.S., compiler, Proceedings of the federal interagency workshop on hydrologic demands for the 90's: U.S. Geological Survey Water-Resources Investigations Report 93-4018, p. 8-50-8-57. 
Wolock, D.M., and McCabe, G.J., 1993, Effects of climate change on water resources in the Delaware River Basin, in Proceedings of the First National Conference on Climate Change and Water Resources Management, Albuquerque, New Mexico, November 5-7, 1991: U.S. Army Corps of Engineers, p. II-140-II-149.

Wolock, D.M., McCabe, G.J., Jr., Tasker, G.D., and Moss, M.E., 1993, Effects of climate change on water resources in the Delaware River Basin: Water Resources Bulletin, v. 29, no. 3, p. 475-486.

Wolock, D.M., and Price, C.V., 1994, Effects of digital elevation model map scale and data resolution on a topography-based watershed model: Water Resources Research, November 1994, v. 30, no. 11, p. 3041-3052.
Zamarripa, G.T., and Perry, C.A., 1993, Multipleregression analysis of climatic factors and Kansas regional precipitation, in Abstract of Papers presented at a Joint Meeting of the Missouri and Kansas Academies of Science, Kansas City, Mo., April 23-24, 1993: Kansas Academy of Science, v. 13, p. 96.

Zelt, R.B., 1991, GIS technology used to manage and analyze hydrologic information: GIS World, August 1991, p. 70-73.

Zimmerman, L.R., and Thurman, E.M., 1993, Trace analysis of the herbicide 2,4-D in water samples by solid-phase extraction (SPE) and enzyme-linked immunosorbent assay (ELISA) [abs.], in Abstract book of 14th annual meeting--Ecological risk assessment, lessons learned?, Houston, Tex., November 14-18, 1993: Society of Environmental Toxicology and Chemistry, p. 522. 


\section{LISTING BY PUBLICATION SERIES}

This index is used when the publication series is known. Entries are by the agency (U.S. Geological Survey, Kansas Geological Survey, Kansas Water Office, and so forth), then by publication series (bulletin, open-file report, circular, and so forth). After you have located the agency and type of publication, citations are listed numerically by report number. Journal of research, progress reports, scientific journal articles, and master's theses are listed alphabetically by the author's last name and initials.

\section{U.S.Geological Survey}

\section{Annual Reports}

This section lists technical papers that concern Kansas water resources and were included in the U.S. Geological Survey's Annual Reports. Beginning with the 23rd annual report $(1901-02)$, these reports contained no technical papers, but separate publication continued until 1933. Since 1933, a condensed form has has been included in the annual report of the Secretary of the Interior.

*14. Natural mineral waters of the United States, by A.C. Peale, 1894: Part 11-B, p. 49-88.

*16. Water resources of a portion of the Great Plains, by Robert Hay, 1895: Part II, p. 535-588.

*18. Report of progress of stream measurements for the calendar year 1896, by A.P. Davis, 1897: Part IV, p. $1-418$.

*19. Report of progress of stream measurements for the calendar year 1897, by F.H. Newell, 1898: Part IV, p. $1-632$.

*20. Report of progress on stream measurements for the calendar year 1898, by F.H. Newell, 1899: Part IV, p. 1-562.

*21. The High Plains and their utilization, by W.D. Johnson, 1901: Part IV-C, p. 743-768.

*21. Report of progress of stream measurements for the calendar year 1899, by F.H. Newell, 1900: p. 9-488.

*22. Report of progress of stream measurements for the calendar year 1900, by F.H. Newell, 1901: p. 9-506.

*22. The High Plains and their utilization (conclusion), by W.D. Johnson, 1902: Part IV-C, p. 671-690.

\section{Bulletins}

U.S. Geological Survey bulletins contain significant data and interpretations that are of lasting scientific interest but generally are more limited in scope or geographic coverage than professional papers. They include the results of resource studies and of geologic and topographic investigations, as well as collections of short papers related to a specific topic.

*32. Lists and analyses of the mineral springs of the United States (a preliminary study), by A.C. Peale, 1886: $235 \mathrm{p}$.

*57. A geological reconnaissance in southwestern Kansas, by Robert Hay, 1890: $49 \mathrm{p}$.
*131. Report of progress of the Division of Hydrography for 1893 and 1894, by F.H. Newell, 1895: 126 p.

*154. A gazetteer of Kansas, by Henry Gannett, 1898: $246 \mathrm{p}$.

*296. Economic geology of the Independence quadrangle, Kansas, by F.C. Schrader and Erasmus Haworth, 1906: $74 \mathrm{p}$.

1087-G. Uranium content of ground and surface waters in a part of the central Great Plains, by E.R. Landis, 1960: p. 223-258.

*1215. Geology of Shawnee County, Kansas, by W.D. Johnson, Jr., W.L. Adkison, and H.C. Wagner, 1967: $254 \mathrm{p}$.

1989-D. Paleohydrology of the Central United States, by D.G. Jorgensen, 1993: $32 \mathrm{p}$.

\section{Circulars}

U.S. Geological Survey circulars present technical or nontechnical information of wide popular interest in a format designed for distribution at no cost to the public. They are published to disseminate administrative information or important scientific information of an ephemeral nature.

*273. Water resources of the Kansas City area, Missouri and Kansas, by V.C. Fishel, J.K. Searcy, and F.H. Rainwater, 1953: $52 \mathrm{p}$.

1120-E. Effects of reservoirs on flood discharges in the Kansas and the Missouri River Basins, 1993-Floods in the upper Mississippi River Basin, by C.A. Perry, 1994: $20 \mathrm{p}$.

\section{Folios of the Geologic Atlases of the United States}

Each folio is named from a city, town, or prominent natural feature within the quadrangle it covers. It includes maps showing the topography, geology, underground structure, and mineral deposits of the area and several pages of descriptive text and illustrations; also maps showing the economic geology, including oil and gas and artesian water, if the conditions in the area mapped warrant their publication. All the folios were published in a library edition, a form measuring $181 / 2 \times 22$ inches.

*109. Description of Cottonwood Falls quadrangle, Kansas, by C.S. Prosser and J.W. Beede, 1904: 6 p., 2 pls. 
*148. Description of the Joplin district, Missouri-Kansas, by W.S.T. Smith and C.E. Siebenthal, 1907: 20 p., 27 figs.

*159. Description of the Independence quadrangle, Kansas, by F.C. Schrader, 1908: 7 p., 3 pls.

*206. Description of the Leavenworth and Smithville quadrangles, Missouri-Kansas, by Henry Hinds and F.C. Greene, 1917: 13 p., 10 pls., 10 figs.

*212. Description of the Syracuse and Lakin quadrangles, Kansas, by N.H. Darton, 1920: 10 p., 6 pls., 7 figs.

\section{Hydrologic Investigations Atlases}

U.S. Geological Survey hydrologic investigations atlases are multicolored or black and white maps on topographic or planimetric bases presenting a wide range of geohydrologic data.

HA-2. Areas of principal ground-water investigations in the Arkansas, White, and Red River Basins, by S.W. Lohman and V.M. Burtis, 1953: 1 sheet, scale $1: 2,500,000$.

HA-3. General availability of ground water and depths to water level in the Arkansas, White, and Red River Basins, by S.W. Lohman, V.M. Burtis, and others, 1953: 1 sheet, scale 1:2,500,000.

HA-14. Floods of the Kansas River, Topeka, Kansas, in 1935 and 1951, by U.S. Geological Survey, 1959: 1 sheet, scale 1:24,000.

HA-58. Emergency water supplies in the Wichita area, Kansas, by C.W. Lane, E.L. Reavis, and G.J. Stramel, 1962: 36 p., 1 sheet, scale 1:250,000

HA-63. Floods at Wichita, Kansas, by D.W. Ellis and others, 1963: 5 sheets, scale 1:24,000.

HA-212. Annual runoff in the conterminous United States, by M.W. Busby, 1966: 1 sheet, scale 1:7,500,000.

HA-217. General availability of ground water and depth to water level in the Missouri River Basin, by G.A. La Rocque, Jr., 1966: 1 sheet, scale 1:2,500,000.

HA-279. Geology and ground water in Labette County, Kansas, by W.L. Jungmann and C.C. Williams, 1968: 1 sheet, scale 1:63,390.

HA-416. Ground water in Kearny County, southwestern Kansas, by E.D. Gutentag, D.H. Lobmeyer, and H.E. McGovern, 1972: 2 sheets, scale 1:125,000.

HA-429. Water resources of northwestern Kansas, by R.H. Pearl, R.S. Roberts, K.M. Keene, and T.J. McClain, 1972: 2 sheets, scale 1:250,000.

HA-442. Ground water in Finney County, southwestern Kansas, by E.D. Gutentag, D.H. Lobmeyer, H.E. McGovern, and W.A. Long, 1972: 3 sheets, scale 1:250,000.

HA-462. Geohydrology of Doniphan County, northeastern Kansas, by C.K. Bayne, 1973: I sheet, scale 1:62,500.
HA-467. Geohydrology of Atchison County, northeastern Kansas, by J.R. Ward, 1973: 2 sheets, scale 1:62,500.

HA-515. Ground water in Haskell County, southwestern Kansas, by E.D. Gutentag and L.E. Stullken, 1974: 2 sheets, scale 1:250,000.

HA-516. Water resources of Hamilton County, southwestern Kansas, by D.H. Lobmeyer and C.G. Sauer, 1974: 2 sheets, scales $1: 250,000$ and 1:500,000.

HA-517. Ground water in Gray County, southwestern Kansas, by H.E. McGovern and W.A. Long, 1974: 2 sheets, scale 1:250,000.

HA-521. Water resources of Gove, Logan, and Wallace Counties, west-central Kansas, by T.J. McClain, E.D. Jenkins, K.M. Keene, and M.E. Pabst, 1975: 2 sheets, scales $1: 250,000$ and $1: 500,000$.

HA-658. Dissolved solids and sodium in water from the High Plains aquifer in parts of Colorado, Kansas, Nebraska, New Mexico, Oklahoma, South Dakota, Texas, and Wyoming, by N.C. Krothe, J.W. Oliver, and J.B. Weeks, 1982: 2 sheets, scale 1:2,500,000.

HA-678. Hydrologic characteristics of soils in parts of Arkansas, Colorado, Kansas, Missouri, Nebraska, New Mexico, Oklahoma, South Dakota, and Texas, by J.T. Dugan, 1986: 1 sheet, scale 1:1,500,000.

HA-688. Flow characteristics for selected springs and streams in the Ozark subregion, Arkansas, Kansas, Missouri, and Oklahoma, by E.R. Hedman, John Skelton, and D.A. Freiwald, 1987: 4 sheets, scale $1: 750,000$.

HA-708. Flow characteristics for selected streams in the Great Plains subregion of the Central Midwest aquifer system and selected adjacent areas-Kansas and Nebraska, and parts of Colorado, Iowa, Missouri, New Mexico, Oklahoma, South Dakota, Texas, and Wyoming, by E.R. Hedman and G.B. Engel, 1989: 3 sheets, scale 1:1,000,000.

HA-711-A. Major geohydrologic units in and adjacent to the Ozark Plateaus Province, Missouri, Arkansas, Kansas, and Oklahoma, by J.L. Imes, 1989: 1 sheet, scale $1: 750,000$.

HA-711-B. Major geohydrologic units in and adjacent to the Ozark Plateaus Province, Missouri, Arkansas, Kansas, and Oklahoma-Basement confining unit, by J.L. Imes, 1989: 1 sheet, scale 1:750,000.

HA-711-C. Major geohydrologic units in and adjacent to the Ozark Plateaus Province, Missouri, Arkansas, Kansas, and Oklahoma-St. Francois aquifer, by J.L. Imes, 1990: 2 sheets, scale 1:750,000.

HA-711-D. Major geohydrologic units in and adjacent to the Ozark Plateaus Province, Missouri, Arkansas, Kansas, and Oklahoma-St. Francois confining layer, by J.L. Imes, 1990: 3 sheets, scale 1:750,000. 
HA-711-E. Major geohydrologic units in and adjacent to the Ozark Plateaus Province, Missouri, Arkansas, Kansas, and Oklahoma-Ozark aquifer, by J.L. Imes, 1990: 3 sheets, scale 1:750,000.

HA-711-F. Major geohydrologic units in and adjacent to the Ozark Plateaus Province, Missouri, Arkansas, Kansas, and Oklahoma-Ozark confining unit, by J.L. Imes, 1990: 3 sheets, scale 1:750,000.

HA-711-G. Major geohydrologic units in and adjacent to the Ozark Plateaus Province, Missouri, Arkansas, Kansas, and Oklahoma-Springfield Plateau aquifer, by J.L. Imes, 1990: 3 sheets, scale 1:750,000.

HA-711-H. Major geohydrologic units in and adjacent to the Ozark Plateaus Province, Missouri, Arkansas, Kansas, and Oklahoma-Western Interior Plains confining system, by J.L. Imes, 1990: 3 sheets, scale $1: 750,000$.

HA-711-J. Water type and concentration of dissolved solids, chloride, and sulfate in water from the St. Francois aquifer in Missouri, Arkansas, Kansas, and Oklahoma, by J.L. Imes and J.V. Davis, 1990: 1 sheet, scale 1:750,000.

HA-711-K. Water type and concentration of dissolved solids, chloride, and sulfate in ground water from the Ozark aquifer in Missouri, Arkansas, Kansas, and Oklahoma, by J.L. Imes and J.V. Davis, 1991: 4 sheets, scale 1:750,000.

HA-711-L. Water type and concentration of dissolved solids, chloride, and sulfate in ground water from the Springfield Plateau aquifer in Missouri, Arkansas, Kansas, and Oklahoma, by J.L. Imes and J.V. Davis, 1990, 2 sheets, scale 1:750,000.

HA-722-A. Geohydrologic systems in Kansas with emphasis on systems in upper Cambrian through Lower Cretaceous rocks, by R.J. Wolf, C.V. Hansen, H.E. McGovern, and J.M. Spinazola, 1990: 2 sheets, scales $1: 1,500,000$ and $1: 2,000,000$.

HA-722-B. Geohydrologic systems in Kansas-Physical framework of the Great Plains aquifer system, by J.M. Spinazola, R.J. Wolf, and H.E. McGovern, 1992: 2 sheets, scales $1: 1,000,000$ and $1: 2,000,000$.

HA-722-C. Geohydrologic systems in Kansas--Physical framework of the Western Interior Plains confining system, by R.J. Wolf, H.E. McGovern, and J.M. Spinazola, 1992: 2 sheets, scales 1:1,000,000 and 1:3,000,000.

HA-722-D. Geohydrologic systems in Kansas-Physical framework of the upper aquifer unit of the Western Interior Plains aquifer system, by C.V. Hansen, E.J. Underwood, R.J. Wolf, and J.M. Spinazola, 1992: 2 sheets, scales $1: 1,000,000$ and $1: 3,000,000$.

HA-722-E. Geohydrologic systems in Kansas-Physical framework of the confining unit in the Western Interior
Plains aquifer system, by C.V. Hansen, R.J. Wolf, and J.M. Spinazola, 1992: 2 sheets, scales 1:1,000,000 and $1: 3,000,000$.

HA-722-F. Geohydrologic systems in Kansas-Physical framework of the lower aquifer unit in the Western Plains aquifer system by C.V. Hansen, J.M. Spinazola, and R.J. Wolf, 1994: 2 sheets, scale 1:1,000,000 and $1: 3,000,000$

HA-722-G. Geohydrologic systems in Kansas-Geohydrology of the Great Plains aquifer system, by H.E. McGovern and R.J. Wolf, 1993: 2 sheets, scales $1: 1,000,000,1: 2,000,000$, and $1: 3,000,000$.

HA-722-H. Geohydrologic systems in Kansas-Geohydrolugy of the upper aquifer unit in the Western Interior Plains aquifer system, by J.F. Kenny, C.V. Hansen, and R.J. Wolf, 1993: 2 sheets, scale $1: 1,500,000$.

HA-722-I. Geohydrologic systems in Kansas-Geohydrology of the lower aquifer unit in the Western Interior Plains aquifer system, by L.J. Combs, C.V. Hansen, and R.J. Wolf, 1993: 3 sheets, scale $1: 1,500,000$.

\section{Journal of Research}

The Journal of Research contains scientific notes and summaries of investigations in geology, hydrology, and related publications. The Journal of Research of the U.S. Geological Survey ceased publication with the volume 6, number 6 (November-December 1978) issue.

Hedman, E.R., and Kastner, W.M., 1977, Streamflow characteristics related to channel geometry in the Missouri River Basin: v. 5, no. 3, p. 285-300.

Hejl, H.R., Jr., 1977, A method for adjusting values of Manning's roughness coefficient for flooded urban areas: v. 5 , no. 5 , p. 541-545.

\section{Miscellaneous Field Studies Maps}

Miscellaneous field studies maps are multicolor or black and white maps on topographic or planimetric bases at various scales. Pre-1971 maps show bedrock geology in relation to specific mining or mineral-deposit problems; post-1971 maps are preliminary black and white maps on various subjects such as environmental studies or mineral investigations.

MF-1835-B. Equivalent freshwater head and dissolvedsolids concentration of water in rocks of Cambrian, Ordovician, and Mississippian age in the northern Midcontinent, U.S.A., by D.G. Jorgensen, J.O. Helgesen, R.B. Leonard, and D.C. Signor, 1986: 2 sheets, scale 1:1,000,000. 


\section{Professional Papers}

U.S. Geological professional papers are mainly comprehensive scientific reports of wide and lasting interest and importance to professional scientists and engineers. Included are reports on the results of resource studies and of topographic, hydrologic, and geologic investigations. They also include collections of related papers addressing different aspects of a single scientific topic.

*32. Preliminary report on the geology and underground water resources of the central Great Plains, by N.H. Darton, 1905: $433 \mathrm{p}$.

*135. The composition of the river and lake waters of the United States, by F.W. Clarke, 1924: 133 p.

*272-D. Evaporation from the 17 Western States by J.S. Meyers, with a section on Evaporation rates, by T.J. Nordenson, 1962: p. 71-100.

*352 D. Channel widening and flood-plain construction along the Cimarron River in southwestern Kansas, by S.A. Schumm and R.W. Lichty, 1963: p. 71-88.

*372-A. The meteorological phenomenon of drought in the Southwest, by H.E. Thomas, 1962: p. Al-A43.

424-B. Recent flood-plain formation along the Cimarron River in Kansas, by S.A. Schumm and R.W. Lichty, 1961: p. B112.

424-D. Hypothetical circulation of ground water around salt springs in western Oklahoma, Texas, and Kansas, by P.E. Ward and A.R. Leonard, 1961: p. D150.

*450-E. Use of a neutron moisture probe to determine the storage coefficient of an unconfined aquifer, by W.R. Meyer, 1963: p. E174-E176.

*501-B. A method for evaluating oil-field-brine pollution of the Walnut River in Kansas, by R.B. Leonard, in Geological Survey Research, 1964, Chapter B, 1964: p. B 173-B176.

*501-C. Relation of annual runoff to meteorological factors, by M.W. Busby, in Geological Survey Research, 1964, Chapter C, 1964: p. C188-C189.

*575-C. Two methods of estimating base flow at ungaged stream sites in Kansas and adjacent States, by L.W. Furness and M.W. Busby, in Geological Survey Research, 1967, Chapter C, 1967: p. C208-C211.

*600-B. Neutron moisture measurements by continuousand point-logging procedures, by R.C. Prill and W.R. Meyer, in Geological Survey Research, 1968, Chapter B, 1968: p. B226-B230.

600-D. Movement of moisture in the unsaturated zone in a dune area, southwestern Kansas, by R.C. Prill, in Geological Survey Research, 1968, Chapter D, 1968: p. D1-D9.

650-D. New locations of Pleistocene (Kansan) molluscan and ostracode faunas, Dickinson County, Kansas, by E.D. Gutentag and Carlos Galli-Olivier, in Geological Survey Research, 1969: p. D148-D154.
1021. Movement of moisture in the unsaturated zone in a loess-mantled area, southwestern Kansas, by R.C. Prill, 1977: $21 \mathrm{p}$.

1169. Floods in Kansas City, Missouri and Kansas, September 12-13, 1977, by L.D. Hauth, W.J. Carswell, Jr., and E.H. Chin, 1981: 47 p.

1200-KS. The National Gazetteer of the United States of America - Kansas 1984, by U.S. Geological Survey in cooperation with the U.S. Board on Geographic Names, 1985: $326 \mathrm{p}$.

1242. Perennial-streamflow characteristics related to channel geometry and sediment in Missouri River Basin, by W.R. Osterkamp and E.R. Hedman, 1982: $37 \mathrm{p}$.

1400-A. Summary of the High Plains regional aquifersystem analysis in parts of Colorado, Kansas, Nebraska, New Mexico, Oklahoma, South Dakota, Texas, and Wyoming, by J.B. Weeks, E.D. Gutentag, F.J. Heimes, and R.R. Luckey, 1988: 30 p.

1400-B. Geohydrology of the High Plains aquifer in parts of Colorado, Kansas, Nebraska, New Mexico, Oklahoma, South Dakota, Texas, and Wyoming, by E.D. Gutentag, F.J. Heimes, N.C. Krothe, R.R. Luckey, and J.B. Weeks, 1984: 63 p.

1400-E. Effects of future ground-water pumpage on the High Plains aquifer in parts of Colorado, Kansas, Nebraska, New Mexico, Oklahoma, South Dakota, Texas, and Wyoming, by R.R. Luckey, E.D. Gutentag, F.J. Heimes, and J.B. Weeks, 1988: 44 p.

1414-B. Regional aquifers in Kansas, Nebraska, and parts of Arkansas, Colorado, Missouri, New Mexico, Oklahoma, South Dakota, Texas, and WyomingGeohydrologic framework, by D.G. Jorgensen, J.O. Helgesen, and J.L. Imes, 1993: 72 p. and 25 pls.

1414-E. Hydrology of the Great Plains aquifer system in Nebraska, Colorado, Kansas, and adjacent areas, by J.O. Helgesen, R.B. Leonard, and R.J. Wolf, 1993: $80 \mathrm{p} ., 10 \mathrm{pls}$.

1464. Interior province-Western region, by H.E. Bevans, in Britton, L.J., Anderson, C.L., Goolsby, D.A., and Van Haveren, B.P., eds., Summary of the U.S. Geological Survey and U.S. Bureau of Land Management National Coal-Hydrology Program, 1974-84, 1989: p. 53-61.

\section{Water-Supply Papers}

U.S. Geological Survey water-supply papers include reports on the geology, hydrology, quality, recoverability, and utilization of water resources. They also include several series of statistical reports on streamflow, floods, ground-water levels, and water quality.

*6. Underground waters of southwestern Kansas, by Erasmus Haworth, 1897: 65 p. 
*67. The motions of underground waters, by C.S. Slichter, 1902: $106 \mathrm{p}$.

*96. Destructive floods in the United States in 1903, contains Kansas floods and hydrographic data, by E.C. Murphy, 1904: $81 \mathrm{p}$.

*145. Water resources of the Joplin district, MissouriKansas, by W.S.T. Smith, 1905: p. 74-83.

*147. Destructive floods in the United States in 1904, contains Kansas floods, by E.C. Murphy and others, 1905: 206 p.

*149. Preliminary list of deep borings in the United States, by N.H. Darton, 1905: 175 p.

*153. The underflow in the Arkansas Valley in western Kansas, by C.S. Slichter, 1906: $90 \mathrm{p}$.

*258. The utilization of the underflow near St. Francis, Kansas, by H.C. Wolff, 1911: p. 98-119.

*273. Quality of the water supplies of Kansas, by H.N. Parker, with a preliminary report on Stream pollution by mine waters in southeastern Kansas, by E.H.S. Bailey, 1911: 375 p.

*345-A. Preliminary report on ground water for irrigation in the vicinity of Wichita, Kansas, by O.E. Meinzer, 1915: 9 p.

*796-B. Flood on Republican and Kansas Rivers, May and June 1935, by Robert Follansbee and J.B. Spiegel, 1937: p. 21-52.

1139. Kansas-Missouri floods of July 1, 1951, by U.S. Geological Survey, with a section on Fluctuations of ground-water levels, by V.C. Fishel, 1952: $239 \mathrm{p}$.

*1499-I. Water resources of the Wichita area, Kansas, by L.R. Petri, C.W. Lane, and L.W. Furness, 1964: 69 p.

*1651. Chemical quality of surface waters and sedimentation in the Saline River Basin, Kansas, by P.R. Jordan, B.F. Jones, and L.R. Petri, 1964: 90 p.

*1669-S. Yearly variations in runoff for the conterminous United States, 1931-60, by M.W. Busby, 1963: p. S1-S49.

*1798-B. Fluvial sediment in the Little Arkansas River Basin, Kansas, by C.D. Albert and G.J. Stramel, 1966: p. B1-B30.

* 1800. Kansas, by V.C. Fishel, in McGuinness, C.L., The role of ground water in the national water situation, 1963: p. 341-353.

*1819-H. Fluvial sediment and chemical quality of water in the Little Blue River Basin, Nebraska and Kansas, by J.C. Mundorff and K.M. Waddell, 1966: p. $\mathrm{H} 1-\mathrm{H} 45$.

1850-D. Floods of June 1965 in Arkansas River Basin, Colorado, Kansas, and New Mexico, by R.J. Snipes and others, 1974: p. D1-D97.
1891. Geohydrology of Finney County, southwestern Kansas, by W.R. Meyer, E.D. Gutentag, and D.H. Lobmeyer, 1970: $117 \mathrm{p}$.

1982. Chemical quality of water in the Walnut River Basin, south-central Kansas, by R.B. Leonard, 1972: 113 p.

2193. Streamflow characteristics related to channel geometry of streams in western United States, by E.R. Hedman and W.R. Osterkamp, 1982: 17 p.

2200. Analysis and computer simulation of stream-aquifer hydrology, Arkansas River Valley, southwestern Kansas, by R.A. Barker, L.E. Dunlap, and C.A. Sauer, 1983: $59 \mathrm{p}$.

2238. Interpolating water-table altitudes in west-central Kansas using kriging techniques, by L.E. Dunlap and J.M. Spinazola, 1984: $19 \mathrm{p}$.

2253. Geohydrology and model analysis of stream-aquifer system along the Arkansas River in Kearny and Finney Counties, southwestern Kansas, by L.E. Dunlap, R.J. Lindgren, and C.G. Sauer, 1985: 52 p.

2268. Assessment of water resources in lead-zinc mined areas in Cherokee County, Kansas, and adjacent areas, by T.B. Spruill, 1987: $68 \mathrm{p}$.

2275. Ground-water resources-Kansas, by H.E. Bevans, T.B. Spruill, and J.F. Kenny, in National water summary 1984-Hydrologic events, selected waterquality trends, and ground-water resources, 1985: p. 217-222.

2280. Magnitude and frequency of high flows of unregulated streams in Kansas, by P.R. Jordan, 1986: 35 p.

2283. Relation of urban land-use and dry-weather, storm, and snowmelt flow characteristics to stream-water quality, Shunganunga Creek Basin, Topeka, Kansas, by L.M. Pope and H.E. Bevans, 1987: 39 p.

2290. Estimating stream-aquifer interactions in coal areas of eastern Kansas by using streamflow records, by H.E. Bevans, in Seymour Subitzky, ed., Selected papers in the hydrologic sciences, 1986: p. 51-64.

2300. Kansas surface-water resources, by P.R. Jordan, in D.W. Moody, E.B. Chase, and D.A. Aronson, compilers, National water summary 1985-Hydrologic events and surface-water resources, 1986: p. 237-244.

2303. Analysis of surface-water data network in Kansas for effectiveness in providing regional streamflow information, by K.D. Medina, with a section on Theory and application of generalized least squares, by G.D. Tasker, 1987: $28 \mathrm{p}$.

2304. Potential hydrologic effects of ground-water withdrawals from the Dakota aquifer, southwestern Kansas, by K.R. Watts, 1985: 72 p.

2321. Using geophysical logs to estimate porosity, water resistivity, and intrinsic permeability, by D.G. Jorgensen, 1988: 24 p. 
2325. Kansas ground-water quality, by C.H. Baker, Jr. and C.V. Hansen, in Moody, D.W., Carr, Jerry, Chase, E.B., and Paulson, R.W., compilers, National Water Summary 1986-Hydrologic events and ground-water quality, 1988: p. 259-264.

2350. Kansas water supply and use, by C.H. Baker, Jr. and J.F. Kenny, in Carr, Jerry, Chase, E.B., Paulson, R.W., and Moody, D.W., compilers, National Water Summary 1987-Water supply and use, 1990: p. 259-266.

2375. Quantification of floods and droughts, by P.R. Jordan and M.E. Jennings, and Kansas floods and droughts, by R.W. Clement, in National water summary 1988-89-Hydrologic events and floods and droughts, by R.W. Paulson, E.B. Chase, R.S. Roberts, and D.W. Moody, compilers, 1991: p. 158-161, p. 287-294.

2381-C. Assessment of nonpoint-source contamination of the High Plains aquifer in south-central Kansas, 1987, by J.O. Helgesen, L.E. Stullken, and A.T. Rutledge, 1994: $51 \mathrm{p}$.

2400. Kansas stream water quality, by J.F. Kenny, in National water summary 1990-91-Hydrologic events and stream water quality, by R.W. Paulson, E.B. Chase, J.S. Williams, and D.W. Moody, compilers, 1993: p. 277-284.

2413. Herbicides and nitrate in near-surface aquifers in the midcontinental United States, 1991, by D.W. Kolpin, M.R. Burkart, and E.M. Thurman, 1994: 34 p.

\section{Water-Resources Investigations Reports}

U.S. Geological Survey water-resources investigations reports (WRIR) are applied to reports that are of an interpretative nature made available to the public outside the formal USGS publications series. WRIR's are not reproduced and distributed in quantity as are formal USGS publications.

41-74. Application of statistical techniques to the estimation of ground-water withdrawals in northwestern Kansas, by W.M. Kastner, 1974: 11 p.

27-75. Land subsidence caused by dissolution of salt near four oil and gas wells in central Kansas, by S.W. Fader, 1975: $28 \mathrm{p}$.

76-12. Results of infiltration tests near Scott City, western Kansas, by J.B. Gillespie and G.D. Hargadine, 1975: $29 \mathrm{p}$.

78-63. Floods in Kansas City, Missouri and Kansas, September 12-13, 1977, by L.D. Hauth and W.J. Carswell, Jr., 1978: 43 p.

78-87. Hydrologic data for Soldier Creek Basin, Kansas, by W.J. Carswell, Jr., 1978: 26 p.

78-135. Guidelines for the use of structural versus regression analysis in geomorphic studies, by W.R.
Osterkamp, J.M. McNellis, and P.R. Jordan, 1978: $22 \mathrm{p}$.

79-15. Variation of alluvial-channel width with discharge and character of sediment, by W.R. Osterkamp, 1979: $11 \mathrm{p}$.

79-49. Relation of sediment yield to climatic and physical characteristics in the Missouri River Basin, by P.R. Jordan, 1979: $26 \mathrm{p}$.

79-92. Evaluation of methods for estimating ground-water withdrawals in western Kansas, by C.H. Baker, Jr., 1979: $70 \mathrm{p}$.

79-105. Hydrologic and related data for water-supply planning in an intensive-study area, northeastern Wichita County, Kansas, by Jack Kume, L.E. Dunlap, E.D. Gutentag, and J.G. Thomas, 1979: 51 p.

80-39. Simulated water-level declines near Marienthal, west-central Kansas, by L.E. Dunlap, 1980: 15 p.

80-74. Preliminary analysis of regional-precipitation periodicity, by C.A. Perry, 1980: $26 \mathrm{p}$.

80-91. Geohydrology and model analysis for water-supply management in a small area of west-central Kansas, by L.E. Dunlap, Jack Kume, and J.G. Thomas, 1980: $59 \mathrm{p}$.

80-111. Evaluating methods for determining water use in the High Plains in parts of Colorado, Kansas, Nebraska, New Mexico, Oklahoma, South Dakota, Texas, and Wyoming, 1979, by F.J. Heimes and R.R. Luckey, 1980: $118 \mathrm{p}$.

81-8. Selected hydrologic relations for Soldier Creek, northeastern Kansas, by W.J. Carswell, Jr., 1981: 68 p.

81-43. Saline ground-water discharge to the Smoky Hill River between Salina and Abilene, central Kansas, by J.B. Gillespie and G.D. Hargadine, 1981: 71 p.

81-65. Results of a reconnaissance water-quality sampling program of the Ogallala aquifer in Colorado, Kansas, Nebraska, Oklahoma, South Dakota, and Texas, by G.L. Feder and N.C. Krothe, 1981: 7 p.

82-11. Nitrate-nitrogen concentrations in ground water from three selected areas in Kansas, by T.B. Spruill, 1982: $32 \mathrm{p}$.

82-12. Sulfur isotopic composition and water chemistry in water from the High Plains aquifer, Oklahoma Panhandle and southwestern Kansas, by N.C. Krothe and J.W. Oliver, 1982: $28 \mathrm{p}$.

82-4005. Water-quality and fluvial-sediment characteristics of selected streams in northeast Kansas, by H.E. Bevans, 1982: $53 \mathrm{p}$.

82-4011. Determination of irrigation pumpage in parts of Kearny and Finney Counties, southwestern Kansas, by R.J. Lindgren, I 982: 26 p. 
82-4074. Physical and hydrological environments of the Mulberry coal reserves in eastern Kansas, by J.F. Kenny, H.E. Bevans, and A.M. Diaz, 1982: 50 p.

82-4079. Hydrologic maps of the High Plains aquifer, January 1981, southwestern Kansas, by J.M. Spinazola, 1982: 8 sheets, scale 1:125,000.

82-4095. A numerical model to evaluate proposed groundwater allocations in southwest Kansas, by D.G. Jorgensen, H.F. Grubb, C.H. Baker, Jr., G.E. Hilmes, and E.D. Jenkins, 1982: $46 \mathrm{p}$.

82-4123. Flood of June 15, 1981 in Great Bend and vicinity, central Kansas, by R.W. Clement and D.G. Johnson, 1982: $12 \mathrm{p}$.

83-4007. Application of remote-sensing techniques to hydrologic studies in selected coal-mined areas of southeastern Kansas, by J.F. Kenny and J.R. McCauley, 1983: $33 \mathrm{p}$.

83-4095. Depth and thickness of selected units in Upper Permian, Upper Jurassic, and Lower Cretaceous rocks in southwestern Kansas, by Jack Kume and J.M. Spinazola, 1983: 7 sheets, scale 1:500,000.

83-4110. Improvement of flood-frequency estimates for selected small watersheds in eastern Kansas using a rainfall-runoff model, by R.W. Clement, 1983: 22 p.

83-4123. Estimating 1980 ground-water pumpage for irrigation on the High Plains in parts of Colorado, Kansas, Nebraska, New Mexico, Oklahoma, South Dakota, Texas, and Wyoming, by F.J. Heimes and R.R. Luckey, 1983: $36 \mathrm{p}$.

83-4226. Hydrology of the Ogallala aquifer in Ford County, southwestern Kansas, by J.M. Spinazola and M.T. Dealy, 1983: $58 \mathrm{p}$.

84-4038. Flood-frequency estimates for five gaged basins in Wichita, Kansas, by C.A. Perry and R.J. Hart, 1984: $23 \mathrm{p}$.

84-4045. Geohydrology and chemical quality of water in Middle and Upper Jurassic and Lower Cretaceous rocks, western Kansas, by Jack Kume, 1984: 54 p.

84-4047. Hydrologic responses of streams to mining of the Mulberry Coal reserves in eastern Kansas, by H.E. Bevans, 1984: $29 \mathrm{p}$.

84-4082. Projected effects of ground-water withdrawals in the Arkansas River Valley, 1980-99, Hamilton and Kearny Counties, southwestern Kansas, by L.E. Dunlap, R.J. Lindgren, and J.E. Carr, 1984: 168 p.

84-4107. Evaluation of the cost effectiveness of the 1983 stream-gaging network in Kansas, by K.D. Medina and C.O. Geiger, 1984: $57 \mathrm{p}$.

84-4162. Hydrology of Prairie Dog Creek Valley, Norton Dam to state line, north-central Kansas, by L.E. Stullken, 1984: $49 \mathrm{p}$.
84-4164. A method of estimating flood volumes in western Kansas, by C.A. Perry, 1984: $18 \mathrm{p}$.

84-4249. Predictive simulations of alternatives for managing the water resources of North Fork Solomon River Valley between Kirwin Dam and Waconda Lake, north-central Kansas, by R.D. Burnett, 1984: 34 p.

84-4292. Availability of natural and regulated streamflows for instream uses during historical droughts, lower Neosho River, southeastern Kansas, by R.J. Hart and T.C. Stiles, 1984: $42 \mathrm{p}$.

84-4306. Water-data program of the U.S. Geological Survey in Kansas, fiscal year 1983, by R.K. Livingston and K.D. Medina, 1984: 33 p.

84-4357. Percentage change in saturated thickness of the High Plains aquifer, west-central Kansas, 1950 to average 1982-84, by M.E. Pabst and B.J. Dague, 1984: 1 sheet, scale 1:125,000.

85-4003. Transit losses and travel times during drought conditions along the Neosho River from Council Grove Lake to Iola, east-central Kansas, by W.J. Carswell, Jr. and R.J. Hart, 1985: 40 p.

85-4058. Water-quality reconnaissance of selected watersupply lakes in eastem Kansas, by L.M. Pope, J.A. Arruda, and A.E. Vahsholtz, 1985: 47 p.

85-4156. Statistical evaluation of the effects of irrigation on chemical quality of ground water and base flow in three river valleys in north-central Kansas, by T.B. Spruill, 1985: $64 \mathrm{p}$.

85-4198. Geohydrology of the High Plains aquifer, western Kansas, by L.E. Stullken, K.R. Watts, and R.J. Lindgren, 1985: $86 \mathrm{p}$.

85-4200. Simulation of the effects of management alternatives of the stream-aquifer system, South Fork Solomon River Valley between Webster Reservoir and Waconda Lake, north-central Kansas, by R.D. Burnett and T.B. Reed, 1985: $19 \mathrm{p}$.

85-4204. Design of a sediment data-collection program in Kansas as affected by time trends, by P.R. Jordan, 1985: $114 \mathrm{p}$.

85-4216. Projected ground-water development, groundwater levels, and stream-aquifer leakage in the South Fork Solomon River Valley between Webster Reservoir and Waconda Lake, north-central Kansas, 1979-2020, by Jack Kume, R.J. Lindgren, and L.E. Stullken, 1985: $42 \mathrm{p}$.

85-4255. Percentage change in saturated thickness of the High Plains aquifer, west-central Kansas, 1950 to average 1983-85, by B.J. Dague, 1985: 1 sheet, scale $1: 125,000$.

85-4263. Transit losses and travel times for water-supply releases from Marion Lake during drought conditions, Cottonwood River, east-central Kansas, by P.R. Jordan and R.J. Hart, 1985: 41 p. 
85-4336. Ground-water flow and solute transport in the Equus-beds area, south-central Kansas, 1940-79, by J.M. Spinazola, J.B. Gillespie, and R.J. Hart, 1985: $68 \mathrm{p}$.

86-4038. Water demands in Kansas, 1944-84, by J.F. Kenny, 1986: $17 \mathrm{p}$.

86-4064. Availability of water for irrigation in the South Fork Solomon River Valley, Webster Reservoir to Waconda Lake, north-central Kansas, by R.D. Burnett and T.B. Reed, 1986: 89 p.

86-4110. Geohydrology of the Wellington-alluvial aquifer system and evaluation of possible locations of relief wells to decrease saline ground-water discharge to the Smoky Hill and Solomon Rivers, central Kansas, by J.B. Gillespie and G.D. Hargadine, 1986: 31 p.

86-4365. Percentage change in saturated thickness of the High Plains aquifer, west-central Kansas, 1950 to average 1984-86, by B.J. Dague, 1986: 1 sheet, scale 1:125,000.

87-4003. Reconnaissance of water quality in the High Plains aquifer beneath agricultural lands, south-central Kansas, by L.E. Stullken, J.K. Stamer, and J.E. Carr, 1987: $25 \mathrm{p}$.

87-4008. Floods in Kansas and techniques for estimating their magnitude and frequency on unregulated streams, by R.W. Clement, 1987: $50 \mathrm{p}$.

87-4097. Measuring and computing natural ground-water recharge at sites in south-central Kansas, by Marios Sophocleous and C.A. Perry, 1987: 48 p.

87-4230. Estimates of freshwater storage and potential natural recharge for principal aquifers in Kansas, by C.V. Hansen, 1991: $100 \mathrm{p}$.

87-4252. Percentage change in saturated thickness of the High Plains aquifer, west-central Kansas, 1950 to average 1985-87, by B.J. Dague, 1987: 1 sheet, scale $1: 125,000$.

88-4015. Description and hydrologic evaluation of nine hazardous-waste sites in Kansas, 1984-86, by R.J. Hart and T.B. Spruill, 1988: 73 p.

88-4039. Hydrologic maps of the High Plains aquifer, southwestern Kansas, January 1986, by L.E. Stullken, 1988: 4 sheets, scale $1: 250,000$.

88-4055. Channel infiltration from floodflows along the Pawnee River and its tributaries, west-central Kansas, by J.B. Gillespie and C.A. Perry, 1988: $30 \mathrm{p}$.

88-4104. Factors affecting leaching in agricultural areas and an assessment of agricultural chemicals in the ground water of Kansas, by C.A. Perry, Victor Robbins, and P.L. Barnes, 1988: 55 p.
88-4161. Relation of trihalomethane-formation potential to water-quality and physical characteristics of small water-supply lakes, eastern Kansas, by L.M. Pope, J.A. Arruda, and C.H. Fromm, 1988: 46 p.

88-4178. An experiment in representative ground-water sampling for water-quality analysis, by T.L. Huntzinger and L.E. Stullken, 1988: 12 p.

88-4220. U.S. Geological Survey Toxic Substances Hydrology Program-Proceedings of the Technical Meeting, Phoenix, Ariz., September 26-30, 1988, by G.E., Mallard, and S.E., Ragone, eds., 1989: 651 p.

Relations between land use and water quality in the High Plains aquifer of south-central Kansas, by J.O. Helgesen and A.T. Rutledge, p. 437-443.

Use of a simplified transport model for pesticides in the unsaturated zone, by A.T. Rutledge and J.O. Helgesen, p. 523-530.

88-4225. Water resources of Sedgwick County, Kansas, by H.E. Bevans, 1989: $119 \mathrm{p}$.

89-4114. Hydrogeology and ground-water-quality conditions at the Geary County Landfill, northeast Kansas, 1988, by N.C. Myers and P.R. Bigsby, 1989: $41 \mathrm{p}$.

89-4190. Preliminary evaluation of the effects of an abandoned soil refinery on chemical quality of water in the Arkansas River Valley, Arkansas City, Kansas, 1985-86, by T.B. Spruill, 1990: $53 \mathrm{p}$.

90-4019. Source, extent, and degradation of herbicides in a shallow aquifer near Hesston, Kansas, by C.A. Perry, 1990: 24 p.

90-4043. Hydrogeology and ground-water-quality conditions at the Emporia-Lyon County Landfill, eastern Kansas, 1988, by N.C. Myers and P.R. Bigsby, 1990: $42 \mathrm{p}$.

90-4065. Characterization of ground-water flow and chemical transport beneath two irrigated fields in south-central Kansas, 1988, by A.T. Rutledge and J.O. Helgesen, 1990: $37 \mathrm{p}$.

90-4098. An axisymmetric finite-difference flow model to simulate drawdown in and around a pumped well, by A.T. Rutledge, 1991: 33 p.

90-4102. Description and evaluation of selected methods used to delineate wellhead-protection areas around public-supply wells near Mt. Hope, Kansas, by C.V. Hansen, 1991: $39 \mathrm{p}$.

90-4117. Hydrogeology and ground-water-quality conditions at the Linn County Landfill, eastern Kansas, 1988-89, by Ronald Falwell, P.R. Bigsby, and N.C. Myers, 1990: $48 \mathrm{p}$. 
90-4153. Water-level changes in the High Plains aquifer underlying parts of South Dakota, Wyoming, Nebraska, Colorado, Kansas, New Mexico, Oklahoma, and Texas-Predevelopment through nonirrigation season 1988-89, by J.T. Dugan, D.E. Schild, and W.M. Kastner, 1990: 29 p.

90-4159. Monitoring regional ground-water quality-Statistical considerations and description of a monitoring network in Kansas, by T.B. Spruill, 1990: $41 \mathrm{p}$.

90-4164. Steady-state unsaturated-zone model to simulate pesticide transport, by A.T. Rutledge and J.O. Helgesen, 1991: 13 p.

91-4008. Percentage change in saturated thickness of the High Plains aquifer, west-central Kansas, 1950 to average 1988-90, by B.J. Pabst, 1991: 1 sheet, scale $1: 125,000$.

91-4017. Observed and simulated distribution of selected herbicides in silty loam, sandy loam, and clay soil profiles near Topeka, Kansas, 1986-88, by C.A. Perry, 1991: $61 \mathrm{p}$.

91-4034. U.S. Geological Survey Toxic Substances Hydrology Program-Proceedings of the Technical Meeting, Monterey, Calif., March 11-15, 1991, by G.E. Mallard and D.A. Aronson, eds.: 730 p.

Geographic and temporal distribution of herbicides in surface waters of the upper midwestern United States, 1989-90, by D.A. Goolsby, E.M. Thurman, and D.W. Kolpin, p. 183-188.

Dissipation of starch-encapsulated herbicides-A field comparison with powdered herbicides, by M.S. Mills, E.M. Thurman, R.E. Wing, and P.L. Barnes, p. 203-209.

Overview of nonpoint-source contamination of the High Plains aquifer in south-central Kansas, by J.O. Helgesen, L.E. Stullken, and A.T. Rutledge, p. 301-306.

Analysis of atrazine metabolites by enzyme-linked immunosorbent assay and gas chromatography/mass spectrometry, by E.M. Thurman, Michael Meyer, and C.D. Adams, p. 568-571.

Comparison of microtitre-plate, enzyme-linked immunosorbent assay (ELISA) and gas chromatography/mass spectrometry (GC/MS) for analysis of herbicides in storm runoff samples, by M.L. Pomes, E.M. Thurman, and D.A. Goolsby, p. 572-575.

91-4049. Statistical comparison of selected chemical constituents in water from chemigation and conventional irrigation wells in Kansas, 1987, by C.A. Perry and M.R. Anderson, 1991: 1 sheet.

91-4060. Reconnaissance investigation of water quality, bottom sediment, and biota associated with irrigated drainage in the Middle Arkansas River Basin,
Colorado and Kansas, 1988-89, by D.K. Mueller, L.R. Deweese, A.J. Garner, and T.B. Spruill, 1991: 84 p.

91-4075. Some guidelines for onsite studies of pesticide leaching in the unsaturated and saturated zones, by C.A. Perry, 1991: 38 p.

92-4137. Ground- and surface-water interaction between the Kansas River and associated alluvial aquifer, northeastern Kansas, by R.J. Wolf and J.O. Helgesen, 1993: $49 \mathrm{p}$.

92-4169. Hydrogeology and ground-water-quality conditions at the Reno County Landfill, south-central Kansas, 1990-91, by B.A. Heck, N.C. Myers, and D.A. Hargadine, 1992: $56 \mathrm{p}$.

92-4177. Hydrogeology and ground-water-quality conditions at the Sumner County Landfill, southcentral Kansas, 1989-90, by N.C. Myers, B.A. Heck, and D.A. Hargadine, 1993: $52 \mathrm{p}$.

93-4018. TOPMODEL, a topographic-based watershed model, by D.M. Wolock, in Burton, J.S., compiler, Proceedings of the federal interagency workshop on hydrologic demands for the 90's, 1993: p. 8-50-8-57.

93-4036. Hydrogeology and ground-water-quality conditions at the Harvey County Landfill, south-central Kansas, 1990, by J.O. Helgesen, B.A. Heck, and D.A. Hargadine, 1993: $44 \mathrm{p}$.

93-4124. Simulating the variable-source-area concept of streamflow generation with the watershed model TOPMODEL, by D.M. Wolock, 1993: 33 p.

93-4177. Geohydrology and saline ground-water discharge to the South Fork Ninnescah River in Pratt and Kingman Counties, south-central Kansas, by J.B. Gillespie and G.D. Hargadine, 1994: 51 p.

94-4166. Hydrogeology and water-quality conditions at the City of Olathe Landfill, east-central Kansas, 1990-93, by P.P. Rasmussen, J.C. Shockley, and D.A. Hargadine, 1994: 44 p.

\section{Water-Resources Investigations, Open-File Reports}

U.S. Geological Survey water-resources investigations reports, open-file reports include unpublished manuscript reports, maps, and other material and are made available for public consultation and use. They are a nonpermanent form of publication that may be cited in other publications as sources of information. They are not considered to be a part of the formal literature.

79-1288. Multiyear low flow in southeastern Kansas, by W.J. Carswell, Jr., 1979: 26 p.

80-734. Multiyear low flow of streams in northeastern Kansas, by W.J. Carswell, Jr. and S.V. Bond, 1980: $26 \mathrm{p}$.

80-764. A procedure for predicting concentrations of dissolved solids and sulfate ion in streams draining areas strip mined for coal, by H.E. Bevans, 1980: $17 \mathrm{p}$. 
81-128. Sediment and channel-geometry investigations for Kansas River Bank-Stabilization Study, Kansas, Nebraska, and Colorado, by W.R. Osterkamp, R.E. Curtis, Jr., and H.G. Crowther, 1981: 72 p.

81-206. Plan of study for the Central Midwest Regional aquifer system analysis in parts of Arkansas, Colorado, Kansas, Missouri, Nebraska, New Mexico, Oklahoma, South Dakota, and Texas, by D.G. Jorgensen and D.C. Signor, 1981: $28 \mathrm{p}$.

81-333. Map of water table in Graham County, northwestern Kansas, March 1979, by J.M. Spinazola, 1981: 1 sheet, scale 1:125,000.

81-334. Map of water table in Solomon River Valley, Waconda Lake to Solomon, north-central Kansas, May 1980, by T.B. Reed, 1985: 1 sheet, scale $1: 125,000$.

81-348. Water-resources investigations of the U.S. Geological Survey in Kansas-Fiscal years 1979 and 1980, by H.E. McGovern and L.J. Combs, 1981: $107 \mathrm{p}$.

83-266. Hydrology of area 40, Western Region, Interior Coal Province, Kansas, Oklahoma, and Missouri, by M.V. Marcher, J.F. Kenny, and others, 1984: 97 p.

83-851. Hydrology of area 39, Western Region, Interior Coal Province, Kansas and Missouri, by H.E. Bevans, John Skelton, J.F. Kenny, and J.V. Davis, 1984: 83 p.

85-4009. Altitude and configuration of the water table in the High Plains aquifer in Kansas, 1980, by M.E. Pabst and L.E. Stullken, 1981: 1 sheet, scale $1: 500,000$.

\section{Techniques of Water-Resources Investigations}

book 5, chap. A1. Methods for determination of inorganic substances in water and fluvial sediments, by M.W. Skougstad and others, 1979: $626 \mathrm{p}$.

\section{Open-File Reports}

U.S. Geological Survey open-file reports (OFR) include unpublished manuscript reports, maps, and other material and are made available for public consultation and use. They are a nonpermanent form of publication that may be cited in other publications as sources of information. They are not considered to be a part of the formal literature.

1940. Memorandum in regard to prospecting for a softer water supply for the Kansas State Penitentiary at Lansing, Kansas, by S.W. Lohman and Alexander Mitchell: $17 \mathrm{p}$.

1951. Chemical quality of the surface waters in the Saline River Basin, Kansas, a progress report, by W.H. Durum: $54 \mathrm{p}$.
1957. History of natural flow, Kansas River, by E.R. Leeson: $5 \mathrm{p}$.

1958. Pumping tests at the Goodyear Tire and Rubber Company, Topeka, Kansas, by U.S. Geological Survey: $12 \mathrm{p}$.

1962. Effect of the Kirwin reservoir, Kansas, on groundwater levels, by M.S. Bedinger and H.H. Tanaka: $11 \mathrm{p}$.

1965. Small area flood volume study, Rock Creek Basin, Meriden, Kansas-Progress report, July 1963 to Feb. 1965, by L.W. Furness: $42 \mathrm{p}$.

1966. Ground water in the Cimarron River Basin, New Mexico, Colorado, Kansas, and Oklahoma, by U.S. Geological Survey: $51 \mathrm{p}$.

1966. Preliminary flood-frequency relations for small streams in Kansas, by T.J. Irza: $19 \mathrm{p}$.

1967. Flood runoff from partially urbanized areas, Wichita, Kansas-Report No. 1, Analysis of initial conditions, by I.C. James, II: $62 \mathrm{p}$.

1968. Streamflow generalization in an area of the central United States, by I.C. James, II: $60 \mathrm{p}$

1969. Evaluation of the effects of the U.S. Bureau of Reclamation ring dike on the ground-water flow and water quality in the Downs area, Kansas, by R.J. Dingman: $19 \mathrm{p}$.

1969. Finney County basic data, by W.R. Meyer, E.D. Gutentag, and D.H. Lobmeyer: $146 \mathrm{p}$.

1970. Ground water in Kearny County, southwestern Kansas, by E.D. Gutentag, D.H. Lobmeyer, and H.E. McGovern: $40 \mathrm{p}$.

1971. Geohydrology of Atchison County, northeastern Kansas, by J.R. Ward: $22 \mathrm{p}$.

1971. Geohydrology of Doniphan County, northeastern Kansas, by C.K. Bayne: 21 p.

1972. Geohydrologic data for numerical modeling of ground-water withdrawals in the Little Arkansas River Basin area, south-central Kansas, by D.B. Richards and T.W. Dunaway: $426 \mathrm{p}$.

1973. Fluvial sediment characteristics of the Kansas River at Wamego, Kansas, 1957-70, by C.D. Albert: 13 p.

1974. Progress report on streamflow characteristics as related to channel geometry of streams in the Missouri River Basin, by E.R. Hedman and W.M. Kastner: 24 p.

4-75. Water development for irrigation in northwestern Kansas, by E.D. Jenkins and M.E. Pabst, 1975: 39 p.

75-365. Ground water in the Verdigris River Basin, Kansas and Oklahoma, by S.W. Fader and R.B. Morton, 1975: $26 \mathrm{p}$.

75-366. Ground water in the Grand (Neosho) River Basin, Kansas and Oklahoma, by R.B. Morton and S.W. Fader, 1975: $35 \mathrm{p}$. 
75-367. Ground water in the Middle Arkansas River Basin, Kansas and Oklahoma, by S.W. Fader and R.B. Morton, 1975: $44 \mathrm{p}$.

76-405. Geohydrologic maps of the Great Bend Prairie, south-central Kansas, by S.W. Fader and L.E. Stullken, 1976: 4 sheets, scale 1:250,000.

76-457. Map showing percent change in saturated thickness of unconsolidated aquifer, 1950-76, west-central Kansas, by E.D. Gutentag, 1975: 1 sheet, scale 1:125,000.

77-264. January 1977 water levels, and data related to water-level changes since 1950, western Kansas, by M.E. Pabst, 1977: 209 p.

77-305. Geohydrology of the Great Bend Prairie, southcentral Kansas, by S.W. Fader and L.E. Stullken, 1977: $53 \mathrm{p}$.

77-675. Map showing percentage decline in saturated thickness of unconsolidated aquifer, 1950-77, westcentral Kansas, by M.E. Pabst, 1977: 1 sheet, scale $1: 126,720$.

78-80. Map showing saturated thickness of the unconsolidated aquifer, southwestern Kansas, January 1975, by E.D. Gutentag, D.H. Lobmeyer, and S.E. Slagle, 1978: I sheet, scale 1:250,000.

78-409. January 1978 water levels, and data related to water-level changes since 1940 or 1950 , western Kansas, by M.E. Pabst, 1978: 179 p.

78-678. Description of data-collection system and synopsis of selected hydrologic data for Soldier Creek Basin, Kansas, by W.J. Carswell, Jr., 1978: 80 p.

78-874. Map showing percentage decrease in saturated thickness of unconsolidated aquifer, 1950-78, westcentral Kansas, by M.E. Pabst, 1978: 1 sheet, scale $1: 126,720$.

78-886. Water in Dakota Formation, Hodgeman and northern Ford Counties, southwestern Kansas, by D.H. Lobmeyer and E.C. Weakly, 1978: 81 p.

78-969. Map showing saturated thickness of unconsolidated aquifer, southwestern Kansas, January 1978, by M.E. Pabst, 1978: 4 sheets, scale I:125,000.

78-974. Determination of peak discharge from rainfall data for urbanized basins, Wichita, Kansas, by C.O. Peek and P.R. Jordan, 1978: $49 \mathrm{p}$.

79-561. Water-resources investigations in Kansas-Fiscal year 1978, by H.E. McGovern and L.J. Combs, 1979: $85 \mathrm{p}$.

79-925. January 1979 water levels, and data related to water-level changes, western and south-central Kansas, by M.E. Pabst, 1979: 213 p.

79-1340. Maps showing saturated thickness, January 1979. and percentage decrease in saturated thickness, 1950-79, of unconsolidated aquifer, west-central
Kansas, by M.E. Pabst, 1979: 2 sheets, scale $1: 125,000$.

80-218. Geohydrology of southwestern Kansas, by E.D. Gutentag, D.H. Lobmeyer, and S.E. Slagle, 1980: $97 \mathrm{p}$.

80-326. The use of minicomputers in a distributed information processing system-A feasibility study, by S.M. Longwill, J.M. McNellis, and D.R. Posson, 1980: $68 \mathrm{p}$.

80-350. Statistical summary of water-quality data for streams draining coal-mined areas, southeastern Kansas, by H.E. Bevans and A.M. Diaz, 1980: 113 p.

80-429. Particle-size analyses of bed and bank material from channels of the Missouri River Basin, by W.R. Osterkamp and A.G. Wiseman, 1980: 31 p.

80-958. January 1980 water levels, and data related to water-level changes, western and south-central Kansas, by M.E. Pabst, 1980: 166 pages.

81-144. Altitude and configuration of water table in High Plains regional aquifer of Kansas, 1975, by L.E. Stullken and M.E. Pabst, 1981: 1 sheet, scale 1:500,000.

81-344. Generalized configuration of the base of the High Plains aquifer in Kansas, by K.R. Watts and L.E. Stullken, 1981: 1 sheet, scale 1:500,000.

81-686. Analysis and computer simulation of streamaquifer hydrology, Arkansas River Valley, southwestern Kansas, by R.A. Barker, L.E. Dunlap, and C.A. Sauer, 1981: 130 p.

81-908. Hydrologic maps of Ogallala aquifer, west-central Kansas, 1978-80, by L.E. Dunlap and J.M. Spinazola, 1981: 4 sheets, scale 1:125,000.

81-925. Location of sampling sites and available information on wells sampled in the Kansas Ground-WaterQuality Monitoring Network, 1976-80, by T.B. Spruill and J.F. Kenny, 1981: 49 p.

81-1001. January 1981 water levels, and data related to water-level changes, western and south-central Kansas, by M.E. Pabst, 1981: $168 \mathrm{p}$.

81-1112. Preliminary data from Arbuckle test wells, Miami, Douglas, Saline, and Labette Counties, Kansas, by Tony Gogel, 1981: $155 \mathrm{p}$.

82-79. Geohydrology of principal aquifers in the Republican River Basin, Kansas, by L.E. Dunlap, 1982: 5 sheets, scale 1:250,000.

82-93. Geometry, basin characteristics, discharge, and particle-size data from gaged stream-channel sites, western United States, by W.R. Osterkamp, E.R. Hedman, and A.G. Wiseman, 1982: 56 p. 
82-117. Altitude and configuration of the water table in the High Plains aquifer in Kansas, pre-1950, by M.E. Pabst and L.E. Stullken, 1982: 1 sheet, scale 1:500,000.

82-258. Hydrologic maps of the Ogallala aquifer, westcentral Kansas, 1979-81, by J.M. Spinazola, 1982: 4 sheets, scale 1:125,000.

82-429. Altitude and configuration of water table in High Plains aquifer in Kansas, 1960, by M.E. Pabst and L.E. Stullken, 1986: 1 sheet, scale 1:500,000.

82-448. Altitude and configuration of water table in High Plains aquifer in Kansas, 1970, by M.E. Pabst and L.E. Stullken, 1985: 1 sheet, scale 1:500,000.

82-449. Altitude and configuration of water table in High Plains aquifer in Kansas, 1965, by M.E. Pabst and L.E. Stullken, 1987: 1 sheet, scale 1:500,000.

82-649. January 1982 water levels, and data related to water-level changes, western and south-central Kansas, by M.E. Pabst, 1982: 167 p.

82-868. Geohydrologic data from sandstone aquifers in southwestern Kansas, by Jack Kume and J.M. Spinazola, 1982: $112 \mathrm{p}$.

82-1010. Map showing percentage change in saturated thickness of the High Plains aquifer, west-central Kansas, 1950 to average $1980-82$, by M.E. Pabst, 1982: 2 sheets, scale 1:125,000.

82-1021. Quality-of-water data and statistical summary for selected coal-mine strip pits in Crawford and Cherokee Counties, southeastern Kansas, by L.M. Pope and A.M. Diaz, 1982: 28 p.

83-222. Geohydrology and model analysis of streamaquifer system along the Arkansas River in Kearny and Finney Counties, southwestern Kansas, by L.E. Dunlap, R.J. Lindgren, and C.G. Sauer, 1983: 84 p.

83-263. Statistical summaries of selected chemical constituents in Kansas ground-water supplies, 1976-81, by T.B. Spruill, 1983: 29 p.

83-528. Kansas ground-water observation-well network, 1983, by M.E. Pabst, 1983: 57 p.

83-762. January 1983 water levels, and data related to water-level changes, western and south-central Kansas, by M.E. Pabst, 1983: $164 \mathrm{p}$.

83-932. Water-resources investigations of the U.S. Geological Survey in Kansas-Fiscal years 1981 and 1982, by J.F. Kenny and L.J. Combs, 1983: 87 p.

84-439. Assessment of water resources in lead-zinc mined areas in Cherokee County, Kansas, and adjacent areas, by T.B. Spruill, 1984: $102 \mathrm{p}$.

84-453. Magnitude and frequency of high flows of unregulated streams in Kansas, by P.R. Jordan, 1984: 45 p.
84-457. Natural ground-water-recharge data from three selected sites in Harvey County, south-central Kansas, by C.A. Perry, 1984: 31 p.

84-609. Water-resources reports prepared by or in cooperation with the U.S. Geological Survey in Kansas, 1886-1983, by L.J. Combs, compiler, 1984: $117 \mathrm{p}$.

84-613. January 1984 water levels, and data related to water-level changes in western and south-central Kansas, by M.E. Pabst and B.J. Dague, 1984: 162 p.

84-750. Relation of urban land-use and dry-weather, storm, and snowmelt flow characteristics to stream-water quality, Shunganunga Creek Basin, Topeka, Kansas, by L.M. Pope and H.E. Bevans, 1984: 64 p.

85-178. Water-resources activities of the U.S. Geological Survey in Kansas-Fiscal years 1983 and 1984, by L.J. Combs, compiler, 1985: $97 \mathrm{p}$.

85-200. Compilation and analyses of aquifer-performance tests in eastern Kansas, by T.B. Reed and R.D. Burnett, 1985: $125 \mathrm{p}$.

85-423. January 1985 water levels, and data related to water-level changes in western and south-central Kansas, by B.J. Dague, 1985: 162 p.

85-641. Federal-State Cooperative Program in Kansas, seminar proceedings, July 1985, by T.L. Huntzinger, 1985: $39 \mathrm{p}$

86-231. Kansas ground-water observation-well network, 1985, by B.J. Dague and L.E. Stullken, 1986: 51 p.

86-317. January 1986 water levels, and data related to water-level changes, western and south-central Kansas, by B.J. Dague, 1986: $165 \mathrm{p}$.

86-480. Two-hundred years of hydrogeology in the United States, by J.S. Rosenshein, J.E. Moore, S.W. Lohman, and E.B. Chase, eds., 1986: 110 p.

86-491. Geohydrology of and potential for fluid disposal in the Arbuckle aquifer, in Kansas, by J.E. Carr, H.E. McGovern, and Tony Gogel, with a section on Log analysis of the Arbuckle aquifer, by J.H. Doveton, 1986: $101 \mathrm{p}$.

87-105. Surface-water-quality assessment of the lower Kansas River Basin, Kansas and Nebraska-Project description, by J.K. Stamer, P.R. Jordan, R.A. Engberg, and J.T. Dugan, 1987: $36 \mathrm{p}$.

87-211. Water-resources activities of the U.S. Geological Survey in Kansas-Fiscal years 1985 and 1986, by L.J. Combs, compiler, 1987: $108 \mathrm{p}$.

87-241. January 1987 water levels, and data related to water-level changes, western and south-central Kansas, by B.J. Dague, 1987: $161 \mathrm{p}$. 
87-396. Index to selected machine-readable geohydrologic data for Precambrian through Cretaceous rocks in Kansas, by J.M. Spinazola, C.V. Hansen, E.J. Underwood, J.F. Kenny, and R.J. Wolf, 1987: 31 p.

87-470. Floodflow characteristics at proposed bridge site for State Highway 99, Kansas River at Wamego, Kansas, by K.D. Medina, 1987: 13 p.

87-726. Kansas ground-water quality, by C.H. Baker, Jr. and C.V. Hansen, 1987: $7 \mathrm{p}$.

88-83. Summary of water data for the Janzen recharge investigation, Scott County, Kansas, 1980-86, by L.E. Stullken, 1988: $38 \mathrm{p}$.

88-160. U.S. Geological Survey ground-water studies in Kansas, by L.J. Combs and T.L. Huntzinger, 1988: 2 p.

88-342. January 1988 water levels, and data related to water-level changes, western and south-central Kansas, by B.J. Pabst, 1988: $158 \mathrm{p}$.

88-409. Transport of chloride and atrazine through the unsaturated zone beneath two irrigated fields in southcentral Kansas by A.T. Rutledge and J.O. Helgesen, in Pederson, G.L., and Smith, M.M., compilers, U.S. Geological Survey Second National Symposium on Water Quality-Abstracts of the Technical Sessions, Orlando, Fla., November 12-17, 1989: p. 81.

88-711. Water supply and demand in Sedgwick County, Kansas, by H.E. Bevans, 1988: 2 p.

89-42. Description of data files compiled for the Central Midwest regional aquifer-system analysis, by J.O. Helgesen and C.V. Hansen, 1989: 37 p.

89-409. U.S. Geological Survey Second National Symposium on Water Quality-Abstracts of the Technical Sessions, Orlando, Fla., November 12-17, 1989, by G.L. Pederson and M.M. Smith, compilers, 1989: $150 \mathrm{p}$.

Concentrating suspended sediment for organic analysis, by M.T. Meyer, E.M. Thurman, and Robert Bannister, p. 61.

Experimental surface-water sampling device for agricultural field-runoff investigations, by C.A. Perry and E.M. Thurman, p. 72.

Transport of organic contaminants in ground water beneath an abandoned oil refinery, by T.B. Spruill, p. 95.

89-592. Water-resources activities of the U.S. Geological Survey in Kansas-Fiscal years 1987 and 1988, by L.J. Combs, compiler, 1989: $97 \mathrm{p}$.

90-581. Surface-water-quality assessment of the lower Kansas River Basin, Kansas and Nebraska-Concentrations of major metals and trace metals in streambed sediments, 1987, by D.Q. Tanner, R.F. Sanzolone, and R.B. Zelt, 1990: 73 p.
91-75. Surface-water-quality assessment of the lower Kansas River Basin, Kansas and Nebraska-Analysis of available water-quality data through 1986 , by P.R. Jordan and J.K. Stamer, eds., 1991: 172 p.

91-88. U.S. Geological Survey Toxic Substances Hydrology Program-Abstracts of the Technical Meeting, Monterey, Calif., March 11-15, 1991, by G.E. Mallard and D.A. Aronson, compilers, 1991: 133 p.

Dissipation of starch-encapsulated herbicides-A field comparison with powdered herbicides, by M.S. Mills, E.M. Thurman, R.E. Wing, and P.L. Barnes, p. 13.

Overview of nonpoint-source contamination of the High Plains aquifer in south-central Kansas, by J.O. Helgesen, L.E. Stullken, and A.T. Rutledge, p. 46.

Analysis of atrazine metabolites by enzyme-linked immunosorbent assay and gas chromatography/mass spectrometry, by E.M. Thurman, Michael Meyer, and C.D. Adams, p. 107.

Comparison of microtitre-plate, enzyme-linked immunosorbent assay (ELISA) and gas chromatography/mass spectrometry (GC/MS) for analysis of herbicides in storm-runoff samples, by M.L. Pomes, E.M. Thurman, and D.A. Goolsby, p. 108.

91-97. National water-quality assessment program-The Central Nebraska Basins, by T.L. Huntzinger, 1991: $2 \mathrm{p}$.

91-186. Geohydrologic data for the South Fork Ninnescah River Valley and adjacent plains in Pratt and Kingman Counties, south-central Kansas, by J.B. Gillespie, G.D. Hargadine, N.C. Myers, and D.A. Hargadine, 1991: $55 \mathrm{p}$.

91-212. Reported water use in Kansas, 1987, by J.F. Kenny, 1991: $39 \mathrm{p}$.

91-468. Water resources on and near Indian lands in northeastern Kansas and southeastern Nebraska-Study description, by T.J. Trombley and J.F. Kenny: $19 \mathrm{p}$.

92-90. Water-resources activities of the U.S. Geological Survey in Kansas-Fiscal years 1989, 1990, and 1991, by L.J. Combs and K.A. Powell, compilers, 1992, $130 \mathrm{p}$.

92-127. Herbicides, water quality and you, by K.E. Juracek, J.F. Kenny, and C.A. Perry, 1992: video.

92-142. Use of a geographic information system to assist with studies of the availability and use of water in Kansas, by K.E. Juracek, 1992: 14 p.

93-51. Surface-water-quality assessment of the lower Kansas River Basin, Kansas and Nebraska-Project data, November 1986 through April 1990, by J.D. Fallon and J.A. McChesney, 1993: 594 p. 
93-87. The occurrence and transport of agricultural pesticides in the Tuttle Creek Lake-stream system, Kansas and Nebraska, by H.E. Bevans, C.H. Fromm, and S.A. Watkins, 1993: $44 \mathrm{p}$.

93-92. Description of geographic-information-system files containing water-resource-related data compiled and collected for Wyandotte County, northeastern Kansas, by C.V. Hansen, 1993: $46 \mathrm{p}$.

93-99. Description of water-resource-related data compiled for Reno County, south-central Kansas, by C.V. Hansen, 1993: $27 \mathrm{p}$.

93-114. Hydrogeologic, water-quality, and land-use data for the reconnaissance of herbicides and nitrate in nearsurface aquifers of the midcontinental United States, 1991, by D.W. Kolpin, M.R. Burkart, and E.M. Thurman, 1993: $61 \mathrm{p}$.

93-116. Description of water-resource-related data compiled for Harvey County, south-central Kansas, 1993, by C.V. Hansen: 29 p.

93-454. U.S. Geological Survey Toxic Substances Hydrology Program-Abstracts of the Technical Meeting, Colorado Springs, Colo., September 20-24, 1993, by D.W. Morganwalp and D.A. Aronson, compilers, 1993: $182 \mathrm{p}$.

Chemistry, degradation, and transport of triazine herbicide metabolites in surface water, by E.M. Thurman, M.S. Mills, and M.T. Meyer, p. 68.

Determining the relative age, transport, and threedimensional distribution of atrazine in a reservoir using immunoassay, by J.D. Fallon and E.M. Thurman, p. 72 .

Isocratic separation of alachIor ethane-sulfonic acid, alachlor oxoacetic acid, and hydroxyatrazine by reversed-phase liquid chromatography, by M.L. Pomes, D.G. Holub, D.S. Aga, and E.M. Thurman, p. 81 .

Atrazine transport and degradation in a pristine watershed-The fate of atrazine deposited by precipitation, by A.E. Cromwell and E.M. Thurman, p. 82.

Reconnaissance data for selected herbicides and two metabolites in surface water of the midwestern United States-Chemical analysis by immunoassay and gas chromatography/mass spectrometry, by E.A. Scribner, E.M. Thurman, and D.A. Goolsby, p. 84.

93-457. Reconnaissance data for selected herbicides, two atrazine metabolites, and nitrate in surface water of the midwestern United States, 1989-90, by E.A. Scribner, E.M. Thurman, D.A. Goolsby, M.T. Meyer, M.S. Mills, and M.L. Pomes, 1993: 77 p.

94-35. Water resources on and near Indian Iands in northeastern Kansas and southeastern Nebraska-Hydrologic data through 1990, by L.D. Brewer, T.J. Trombley, and M.J. Pomes, 1994: 424 p.
94-46. Description and use of a geographic-informationsystem-based water information management and analysis system (WIMAS), by K.E. Juracek, 1994: $20 \mathrm{p}$.

94-89. Water-resources activities of the U.S. Geological Survey in Kansas-Fiscal years 1992 and 1993, and plans for fiscal year 1994, by K.A. Powell, 1994: 122 p.

94-396. Concentrations of selected herbicides, two triazine metabolites, and nutrients in storm runoff from nine stream basins in the midwestern United States, 1990-92, by E.A. Scribner, D.A. Goolsby, E.M. Thurman, M.T. Meyer, and M.L. Pomes, 1994: 144 p.

94-497. Concentrations of triazine herbicides in the unsaturated zone in western Harvey County, Kansas, spring and fall 1992-93, by K.E. Juracek, 1994: 23 p.

\section{Water-Data Reports}

Kansas records of discharge or stage of streams and contents or stage of lakes and reservoirs were first published in a series of U.S. Geological Survey water-supply papers entitled "Surface Water Supply of the United States." Through September 30,1960, these water-supply papers were in an annual series and then in a 5-year series for 1960-65 and 1966-70.

Records of chemical quality, water temperatures, and suspended sediment were published from 1941 to 1970 in an annual series of water-supply papers entitled "Quality of Surface Waters of the United States." Records of ground-water levels were published from 1935 to 1974 in a series of water-supply papers entitled "Ground-Water Levels in the United States." Water-supply papers may be consulted in the libraries of the principal cities in the United States or may be purchased from the U.S. Geological Survey, Earth Science Information Center, Open-File Reports Section, Box 25286, MS 517, Denver Federal Center, Denver, CO 80225.

For water years 1961 through 1970, streamflow data were released by the Geological Survey in annual reports on a Stateboundary basis. Water-quality records for water years 1964 through 1970 were similarly released either in separate reports or in conjunction with streamflow records.

Beginning with the 1971 water year, water data for streamflows, water quality, and ground water are published as an official Survey report on a State-boundary basis. These official Survey reports carry an identification number consisting of the two-letter State abbreviation, the last two digits of the water year and the volume number; for example, "U.S. Geological Survey Water-Data Report KS-82-1." These water-data reports are for sale in paper copy or in microfiche by the National Technical Information Service, U.S. Department of Commerce, Springfield, VA 22161.

1962. Surface water records of Kansas, 1961: $165 \mathrm{p}$. 1963. Surface water records of Kansas, 1962: $179 \mathrm{p}$. 1964. Surface water records of Kansas, 1963: $191 \mathrm{p}$. 1965. Surface water records of Kansas, 1964: $215 \mathrm{p}$. 1966. Water quality records in Kansas, 1964: 205 p. 
1966. Water resources data for Kansas-Part 1, Surface water records, 1965: $202 \mathrm{p}$.

1967. Water resources data for Kansas-Part 1, Surface water records, 1966: $202 \mathrm{p}$.

1967. Water resources data for Kansas-Part 2, Water quality records, 1965: $223 \mathrm{p}$.

1968. Water resources data for Kansas-Part 1, Surface water records, 1967: $204 \mathrm{p}$.

1968. Water resources data for Kansas-Part 2, Water quality records, 1966: $223 \mathrm{p}$.

1969. Water resources data for Kansas-Part 1, Surface water records, 1968: $212 \mathrm{p}$.

1970. Water resources data for Kansas-Part 1, Surface water records, 1969: $216 \mathrm{p}$.

1970. Water resources data for Kansas-Part 2, Water quality records, 1967: $191 \mathrm{p}$.

1970. Water resources data for Kansas-Part 2, Water quality records, 1968: $225 \mathrm{p}$.

1971. Water resources data for Kansas-Part 2, Water quality records, 1969: $201 \mathrm{p}$.

1971. Water resources data for Kansas-_Part 1, Surface water records, 1970: $216 \mathrm{p}$.

1971. Water resources data for Kansas-Part 2, Water quality records, 1970: $159 \mathrm{p}$.

1972. Water resources data for Kansas-Part 1, Surface water records, 1971: $206 \mathrm{p}$.

1972. Water resources data for Kansas-Part 2, Water quality records, 1971: $140 \mathrm{p}$.

1973. Water resources data for Kansas-Part 1, Surface water records, 1972: $202 \mathrm{p}$.

1973. Water resources data for Kansas-Part 2, Water quality records, 1972: $154 \mathrm{p}$.

1974. Water resources data for Kansas-Part 1, Surface water records, 1973: $202 \mathrm{p}$.

1974. Water resources data for Kansas-Part 2, Water quality records, 1973: $168 \mathrm{p}$.

1975. Water resources data for Kansas-Part 1, Surface water records, 1974: $202 \mathrm{p}$.

1975. Water resources data for Kansas-Part 2, Water quality records, 1974: $188 \mathrm{p}$.

KS-75-1. Water resources data for Kansas, water year 1975, 1976: $405 \mathrm{p}$.

KS-76-1. Water resources data for Kansas, water year 1976, 1977: $395 \mathrm{p}$.

KS-77-1. Water resources data for Kansas, water year 1977, 1978: $618 \mathrm{p}$.

KS-78-1. Water resources data for Kansas, water year 1978, 1979: $656 \mathrm{p}$.

KS-79-1. Water resources data for Kansas, water year 1979-Volume 1. Missouri Basin, 1980: 372 p.

KS-79-2. Water resources data for Kansas, water year 1979-Volume 2. Arkansas River Basin, 1980: 372 p.
KS-80-1. Water resources data for Kansas, water year 1980-Volume 1. Missouri River Basin, 1981: 422 p.

KS-80-2. Water resources data for Kansas, water year 1980-Volume 2. Arkansas River Basin, 1981: 340 p.

KS-81-1. Water resources data for Kansas, water year 1981, 1982: $566 \mathrm{p}$.

KS-82-1. Water resources data, Kansas, water year 1982, by C.O. Geiger, D.L. Lacock, L.R. Shelton, M.L. Penny, and C.E. Merry, 1983: 485 p.

KS-83-1. Water resources data, Kansas, water year 1983, by C.O. Geiger, D.L. Lacock, L.R. Shelton, M.L. Penny, and C.E. Merry, 1984: 483 p.

KS-84-1. Water resources data, Kansas, water year 1984, by C.O. Geiger, D.L. Lacock, L.R. SheIton, M.L. Penny, and C.E. Merry, 1985: 500 p.

KS-85-1. Water resources data, Kansas, water year 1985 , by C.O. Geiger, D.L. Lacock, J.E. Putnam, B.L. Riche, and C.E. Merry, 1986: 478 p.

KS-86-1. Water resources data, Kansas, water year 1986, by C.O. Geiger, D.L. Lacock, J.E. Putnam, C.E. Merry, and D.R. Schneider, 1987: 482 p.

KS-87-1. Water resources data, Kansas, water year 1987 , by C.O. Geiger, D.L. Lacock, J.E. Putnam, C.E. Merry, and D.R. Schneider, 1988: 492 p.

KS-88-1. Water resources data, Kansas, water year 1988 , by C.O. Geiger, D.L. Lacock, D.R. Schneider, M.D. Carlson, and C.E. Merry, 1989: 490 p.

KS-89-1. Water resources data, Kansas, water year 1989 , by C.O. Geiger, D.L. Lacock, D.R. Schneider, M.D. Carlson, and C.E. Merry, 1990: 457 p.

KS-90-1. Water resources data, Kansas, water year 1990 , by C.O. Geiger, D.L. Lacock, D.R. Schneider, M.D. CarIson, and B.J. Pabst, 1991: 370 p.

KS-91-1. Water resources data, Kansas, water year 1991, by C.O. Geiger, D.L. Lacock, D.R. Schneider, M.D. CarIson, and B.J. Pabst, 1992: 358 p.

KS-92-1. Water resources data, Kansas, water year 1992, by C.O. Geiger, D.L. Lacock, D.R. Schneider, M.D. Carlson, and B.J. Dague, 1993: 500 p.

KS-93-1. Water resources data Kansas, water year 1993 , by C.O. Geiger, D.L. Lacock, D.L. Schneider, M.D. Carlson, and B.J. Dague, 1994: 497 p.

\section{Miscellaneous Publications}

Miscellaneous publications are brief nontechnical summaries of topics often asked about, such as earthquakes, energy resources, mineral resources, water resources, volcanoes, glaciers, and rivers. Also listed under miscellaneous publications are U.S. Geological Survey folders, a series of folders entitled "Water Resources Investigations in (State)" that outline the Geological Survey's water-resources program in the 50 States and Puerto Rico. Each folder has a large map that shows the location of stream-gaging stations, observation wells, quality-of-water 
sampling sites, and investigations in progress. Smaller maps show other significant hydrologic aspects. A brief text explains the Water Resources Division's cooperative program and the hydrologic-data network. Also given are the investigations in progress and a selected list of references.

*1935. Ground water in the southern High Plains, by C.V. Theis, H.P. Burleigh, and H.A. Waite, 1935: U.S. Department of the Interior Memorandum for the Press, October $1935,4 \mathrm{p}$.

1964. Status of water resources investigations in Kansas: U.S. Geological Survey folder.

1966. Water resources investigations in Kansas, 1965: U.S. Geological Survey folder.

1969. Water resources investigations in Kansas, 1968: U.S. Geological Survey folder.

1972. Water resources investigations in Kansas, 1972: U.S. Geological Survey folder.

1978. Water resources investigations in Kansas: U.S. Geological Survey folder.

1978. Water resources investigations in Kansas, fiscal year 1977, by U.S. Geological Survey: 80 p.

1978. Water resources investigations in Kansas, 1978: U.S. Geological Survey Water Index folder.

\section{Outside Publications-Articles and Reports}

Articles prepared by or in cooperation with U.S. Geological Survey personnel in non-U.S. Geological Survey publications that came to our attention for 1886-1994 are listed below:

\section{Kansas Department of Health and Environment}

\section{Bulletins}

1-2. The relation of the chemical quality of the Whitewater River at Towanda to that of the Walnut River at Winfield, Kansas during the 1963 water year, by R.B. Leonard and K.L. Shah, 1964: 18 p.

1-3. Results of four chemical-quality surveys of the Walnut River Basin, Kansas (December 1961 to October 1963), by R.B. Leonard, 1964: 38 p.

1-4. Chemical quality of surface waters in Kansas, 1962 water year, by J.L. Mayes and Don Culbertson, 1964: $61 \mathrm{p}$.

1-5. Brine in surface water of the Little Arkansas River Basin, Kansas, by C.D. Albert, 1964: 15 p.

1-7. Chemical quality of public water supplies in Kansas, by J.L. Mayes, G.A. Stoltenberg, and N.J. Burris, 1965: 39 p.

1-8. Chemical quality of surface waters in Kansas, 1963 water year, by J.L. Mayes and A.M. Diaz, 1965: 67 p.
1-10. Effect of irrigation on the chemical quality of Iow streamflow adjacent to Cedar Bluff Irrigation District, Kansas, a progress report, by R.B. Leonard, 1969: $17 \mathrm{p}$.

1-11. Variations in the chemical quality of ground water beneath an irrigated field, Cedar Bluff Irrigation District, Kansas, by R.B. Leonard, 1970: 20 p.

1-12. Compilation of data for water-quality investigation, Cedar Bluff lrrigation District, Kansas, by R.B. Leonard and G.A. Stoltenberg, 1972: 158 p.

B2-49. Urban water-quality data and statistical summaries for selected sites in the Shunganunga Creek Basin, Topeka, Kansas, by L.M. Pope, A.M. Diaz, and M.K. Butler, 1983: 203 p.

\section{Kansas Geological Survey}

\section{Bulletins}

*27. Ground-water resources of Kansas (with chapters by S.W. Lohman, J.C. Frye, H.A. Waite, T.G. McLaughlin, and B.F. Latta), by R.C. Moore, 1940: $112 \mathrm{p}$.

*35. A preliminary report on the water supply of the Meade Artesian Basin, Meade County, Kansas, by J.C. Frye, 1940: $39 \mathrm{p}$.

*37. Geology and ground-water resources of Stanton County, Kansas, by B.F. Latta, 1941: 119 p.

*38, pt. 2. Ground-water conditions in the vicinity of Lawrence, Kansas, by S.W. Lohman, 1941: 64 p.

*38, pt. 9. Reconnaissance of ground-water resources of Atchison County, Kansas, by J.C. Frye, 1941: p. 237-260.

*40. Geology and ground-water resources of Morton County, Kansas, by T.G. McLaughlin, 1942: 126 p.

*41, pt. 1. Ground-water supplies available for national defense industries in south-central Kansas, by S.W. Lohman, 1942: 19 p.

*41, pt. 2. Ground-water supplies available in Kansas for national defense industries, by S.W. Lohman, J.C. Frye, H.A. Waite, V.C. Fishel, T.G. McLaughlin, B.F. Latta, and G.E. Abernathy, 1942: p. 21-28.

*43. Geology and ground-water resources of Ford County, Kansas, by H.A. Waite, 1942: 250 p.

*45. Geology and ground-water resources of Meade County, Kansas, by J.C. Frye, 1942: 152 p.

*49. Geology and ground-water resources of Hamilton and Kearny Counties, Kansas, by T.G. McLaughlin, 1943: $220 \mathrm{p}$.

*50. Ground water in the oil-field areas of Ellis and Russell Counties, Kansas, by J.C. Frye, J.J. Brazil, and H.A. Stoltenberg, 1943: 104 p. 
*52, pt. 2. Ground-water conditions in the Neosho River Valley in the vicinity of Parsons, Kansas, by C.C.Williams, 1944: p. 29-80.

*55. Geology and ground-water resources of Finney and Gray Counties, Kansas, by B.F. Latta, 1944: 272 p.

*59. Geology and ground-water resources of Thomas County, Kansas, by J.C. Frye, 1945: 110 p.

*61. Geology and ground-water resources of Grant, Haskell, and Stevens Counties, Kansas, by T.G. McLaughlin, 1946: $221 \mathrm{p}$.

*64, pt. 3. Ground-water conditions in Elm Creek Valley, Barber County, Kansas, by C.C. Williams and C.K. Bayne, 1946: p. 77-124.

*64, pt. 5. Ground-water conditions in Arkansas River Valley in the vicinity of Hutchinson, Kansas, by C.C. Williams, 1946: p. 145-216.

*65. Geology and ground-water resources of Kiowa County, Kansas, by B.F. Latta, 1948: 151 p.

*66. Geology and ground-water resources of Scott County, Kansas, by H.A. Waite, 1947: 216 p.

*69. Geology and ground-water resources of Seward County, Kansas, by F.E. Byrne and T.G. McLaughlin, 1947: $140 \mathrm{p}$.

*71. Ground-water resources of the Kansas City, Kansas area, by V.C. Fishel, 1948: 109 p.

*73. Geology and ground-water resources of Republic County and northern Cloud County, Kansas, by V.C. Fishel, 1948: $194 \mathrm{p}$.

*76, pt. 2. Contamination of deep water wells in southeastem Kansas, by C.C. Williams, 1948: p. 13-28.

*76, pt. 6. Ground-water supplies at Hays, Victoria, Walker, Gorham, and Russell, Kansas, with special reference to future needs, by B.F. Latta, 1948: p. 121-196.

*79. Geology and ground-water resources of a part of south-central Kansas, with specific references to the Wichita municipal water supply, by C.C. Williams and S.W. Lohman, 1949: 455 p.

*80. Geology and ground-water resources of Pawnee and Edwards Counties, Kansas, by T.G. McLaughlin, 1949: $189 \mathrm{p}$.

*81. Geology and ground-water resources of Norton County and northwestem Phillips County, Kansas, by J.C. Frye and A.R. Leonard, 1949: 144 p.

*84. Ground-water conditions in the Smoky Hill Valley in Saline, Dickinson, and Geary Counties, Kansas, by B.F. Latta, 1949: $152 \mathrm{p}$.

*85. Geology and ground-water resources of Rice County, Kansas, by O.S. Fent, 1950: 142 p.
*86, pt. 6. Subsurface reconnaissance of glacial deposits in northeastern Kansas, by J.C. Frye and K.L. Walters, 1950: p. 141-158.

*88. Geology and ground-water resources of Barton and Stafford Counties, Kansas, by B.F. Latta, 1950: 228 p.

*93. Geology and ground-water resources of Lane County, Kansas, by G.C. Prescott, Jr., 1951: 126 p.

*94. Ground-water resources of Pawnee Valley, Kansas, by V.C. Fishel, 1952: 144 p.

95. Geology and ground-water resources of Lincoln County, Kansas, by D.W. Berry, with a chapter on The chemical quality of ground water, by W.H. Durum, 1952: $96 \mathrm{p}$.

*96, pt. 5. Geology and ground-water resources of the Kansas River Valley between Lawrence and Topeka, Kansas, by S.N. Davis and W.A. Carlson, 1952: p. 201-276.

98. Geology and ground-water resources of the North Fork Solomon River in Mitchell, Osborne, Smith, and Phillips Counties, Kansas, by A.R. Leonard, 1952: $150 \mathrm{p}$.

100. Geology and ground-water resources of Cheyenne County, Kansas, by G.C. Prescott, Jr., 1953: 106 p.

101. Geology and ground-water resources of Jackson County, Kansas, by K.L. Walters, 1953: 91 p.

105. Geology and ground-water resources of Sherman County, Kansas, by G.C. Prescott, Jr., 1953: 130 p.

106. Geology and ground-water resources of Marshall County, Kansas, by K.L. Walters, 1954: 116 p.

108. Geology and ground-water resources of Wichita and Greeley Counties, Kansas, by G.C. Prescott, Jr., J.R. Branch, and W.W. Wilson, 1954: $134 \mathrm{p}$.

110. Geology and ground-water resources of Graham County, Kansas, by G.C. Prescott, Jr., 1955: 98 p

115. Geology and ground-water resources of Jewell County, Kansas, by V.C. Fishel and A.R. Leonard, 1955: $152 \mathrm{p}$.

116. Geology and ground-water resources of Sheridan County, Kansas, by C.K. Bayne, 1956: 94 p.

117. Geology and water-resources of Rawlins County, Kansas, by K.L. Walters, 1956: 100 p.

119, pt. 1. Progress report on the ground-water hydrology of the Equus-beds area, Kansas, by G.J. Stramel, 1956: $59 \mathrm{p}$.

120. Geology and ground-water resources of Reno County, Kansas, by C.K. Bayne, 1956: $130 \mathrm{p}$.

*125. Ground-water levels in observation wells in Kansas, 1956, by V.C. Fishel and B.J. Mason, 1957: 158 p.

126. Ground-water resources of the Ladder Creek area in Kansas, by Edward Bradley and C.R. Johnson, with a section on The chemical quality of water, by R.A. Krieger, 1957: 194 p. 
127, pt. 5. The hydraulic properties of the Ordovician rocks at Pittsburg, Kansas, by G.J. Stramel, 1957:

p. 153-178.

129. Geology and ground-water resources of Logan County, Kansas, by C.R. Johnson, 1958: 175 p.

130, pt. 1. Quaternary geology and ground-water resources of the Kansas River Valley between Bonner Springs and Lawrence, Kansas, by A.E. Dufford, 1958: 96 p.

*131. Ground-water levels in observation wells in Kansas, 1957, by V.C. Fishel and B.J. Mason, 1958: 152 p.

132. Geology and ground-water hydrology of the Ingalls area, Kansas, by G.J. Stramel, C.W. Lane, and W.G. Hodson, 1958: $154 \mathrm{p}$.

136. Geology and ground-water resources of Clay County, Kansas, by K.L. Walters and C.K. Bayne, 1959: $106 \mathrm{p}$.

139. Geology and ground-water resources of Cloud County, Kansas, by C.K. Bayne and K.L. Walters, 1959: 144 p.

140. Geology and ground-water resources of Mitchell County, Kansas, by W.G. Hodson, 1959: 132 p.

*141. Ground-water levels in observation wells in Kansas, 1958, by V.C. Fishel, E.L. Gulley, and E.L. Reavis, 1959: $146 \mathrm{p}$.

143. Geology and ground-water resources of Harper County, Kansas, by C.K. Bayne, 1960: 183 p.

144. Geology and ground-water resources of Kingman County, Kansas, by C.W. Lane, 1960: 173 p.

145. Geology and ground-water resources of Gove County, Kansas, by W.G. Hodson and K.D. Wahl, 1960: 126 p.

*146. Ground-water levels in observation wells in Kansas, 1959, by V.C. Fishel and M.E. Broeker, 1960: 174 p.

*148. Geology and ground-water resources of Douglas County, Kansas, by H.G. O'Connor, 1960: 200 p.

149. Geology and ground-water resources of southern Ellis County and parts of Trego and Rush Counties, Kansas, by A.R. Leonard and D.W. Berry, 1961: 156 p.

151. Geology and ground-water resources of Sumner County, Kansas, by K.L. Walters, 1961: 198 p.

*153. Ground-water levels in observation wells in Kansas, 1960, by M.E. Broeker and V.C. Fishel, 1961: 183 p.

154. Geology and ground-water resources of Ottawa County, Kansas, by L.E. Mack, 1962: 145 p.

158. Geology and ground-water resources of Cowley County, Kansas, by C.K. Bayne, 1962: 219 p.

*159. Ground-water levels in observation wells in Kansas, 1961, by M.E. Broeker and V.C. Fishel, 1962: 165 p.

161. Geology and ground-water resources of Wallace County, Kansas, by W.G. Hodson, 1963: 108 p.

*167. Ground-water levels in observation wells in Kansas, 1962, by M.E. Broeker and J.D. Winslow, 1963: 89 p.
168. Geohydrology of Grant and Stanton Counties, Kansas, by S.W. Fader, E.D. Gutentag, D.H. Lobmeyer, and W.R. Meyer, 1964: 147 p.

*173. Ground-water levels in observation wells in Kansas, 1963, by M.E. Broeker and J.D. Winslow, 1964: 93 p.

174. Geology and ground-water resources of Trego County, Kansas, by W.G. Hodson, 1965: 80 p.

176. Geohydrology of Sedgwick County, Kansas, by C.W. Lane and D.E. Miller, 1965: 100 p.

*177. Ground-water levels in observation wells in Kansas, 1964, by M.E. Broeker and J.D. Winslow, 1965: 93 p.

181. Geology and ground-water resources of Miami County, Kansas, by D.E. Miller, 1966: 66 p.

182. Ground water in Kansas-Bibliography and subject index, by R.S. Roberts and W.G. Hodson, 1966: 41 p.

183. Geology and ground-water resources of Neosho County, Kansas, by W.L. Jungmann, 1966: 46 p.

184. Ground-water levels in observation wells in Kansas, 1965, by M.E. Broeker and J.D. Winslow, 1966: 92 p

186. Geology and ground-water resources of Brown County, Kansas, by C.K. Bayne and W.H. Schoewe, 1967: $68 \mathrm{p}$.

187, pt. 2. Progress report on the ground-water hydrology of the Equus-beds area, Kansas, 1966, by G.J. Stramel, 1966: $27 \mathrm{p}$.

188. Ground water in the Republican River area, Cloud, Jewell, and Republic Counties, Kansas, by S.W. Fader, 1968: $27 \mathrm{p}$.

193. Geology and ground-water resources of Linn County, Kansas, by W.J. Seevers, 1969: $62 \mathrm{p}$.

194, pt. 1. Computer applications in hydrology in Kansas by C.O. Morgan, J.M. McNellis, and B.H. Lowell, 1969, in Zeller, D.E., ed., Short papers on research, 1968: p. 3-7.

195. Geology and ground-water resources of Allen County, Kansas, by D.E. Miller, 1969: 50 p.

196. Geology and ground-water resources of Decatur County, Kansas, by W.G. Hodson, 1969: 41 p.

201. Geology and ground-water resources of Ellsworth County, central Kansas, by C.K. Bayne, P.C. Franks, and William Ives, Jr., 1971: 84 p.

202, pt. 4. Geohydrology of Jefferson County, northeastern Kansas, by J.D. Winslow, 1972: 20 p.

203. Geology and ground-water resources of Johnson County, northeastern Kansas, by H.G. O'Connor, 1971: $68 \mathrm{p}$.

204, pt. 1. Numerical solution of the three-dimensional heat flow equation, by J.C. Halepaska and J.W. Hartman, 1972: p. 11-13. 
205. Geology and ground-water resources of Pratt County, south-central Kansas, by D.W. Layton and D.W. Berry, 1973: $33 \mathrm{p}$.

206, pt. 2. Ground water in the Kansas River Valley, Junction City to Kansas City, Kansas, by S.W. Fader, 1974: $12 \mathrm{p}$.

206, pt. 3. Geology and hydrology of Rice County, central Kansas, by C.K. Bayne and J.R. Ward, 1974: 17 p.

207. Geology and ground-water resources of Rush County, central Kansas, by J.M. McNellis, 1973: 45 p.

\section{Basic-Data Series, Ground-Water Releases}

*1. Hydrogeologic data from Cheyenne, Decatur, Rawlins, Sheridan, Sherman, and Thomas Counties, Kansas, by K.M. Keene, R.H. Pearl, and M.E. Pabst, 1969: 113 p.

*2. Hydrogeologic data from Gove, Logan, and Wallace Counties, Kansas, by K.M. Keene and M.E. Pabst, 1971: $76 \mathrm{p}$.

3. Ground-water levels in observation wells in Kansas, 1966-70, by M.E. Broeker and J.M. McNellis, 1973: $373 \mathrm{p}$.

4. Hydrogeologic data from Greeley, Wichita, Scott, and Lane Counties, Kansas, by L.E. Stullken, E.C. Weakly, E.D. Gutentag, and S.E. Slagle, 1974: 58 p.

5. Hydrogeologic data from the Great Bend Prairie, southcentral Kansas, by L.E. Stullken and S.W. Fader, 1976: $50 \mathrm{p}$.

6. Ground-water levels in observation wells in Kansas, 1971-75, by M.E. Broeker, H.J. McIntyre, Jr., and J.M. McNellis, 1977: $526 \mathrm{p}$.

7. Hydrogeologic data from north-central Kansas, by L.E. Stullken, 1980: $46 \mathrm{p}$.

\section{Chemical Quality Series}

1. Changes in chemical quality of water, Cedar Bluff Irrigation District area, west-central Kansas, by R.B. Leonard, 1974: $72 \mathrm{p}$.

2. Chemical quality of irrigation waters in west-central Kansas, by L.R. Hathaway, L.M. Magnuson, B.L. Carr, O.K. Galle, and T.C. Waugh, 1975: 46 p.

3. Saline water in the Little Arkansas River Basin area, south-central Kansas, by R.B. Leonard and M.K. Kleinschmidt, 1976: 24 p.

4. Chemical quality of irrigation waters in Hamilton, Kearny, Finney, and northern Gray counties, by L.R. Hathaway, B.L. Carr, O.K. Galle, L.M. Magnuson, T.C. Waugh, and H.P. Dickey, 1977: 33 p.

5. Ground water from Lower Cretaceous rocks in Kansas, by K.M. Keene and C.K. Bayne, 1977: 18 p.

6. Chemical quality of irrigation waters in southwestern Kansas, by L.R. Hathaway, B.L. Carr, M.A. Flanagan,
O.K. Galle, T.C. Waugh, H.P. Dickey, and L.M. Magnuson, 1978: $35 \mathrm{p}$.

7. Chemical quality of irrigation waters in Ford County and the Great Bend Prairie of Kansas, by L.R. Hathaway, O.K. Galle, T.C. Waugh, and H.P. Dickey, 1978: 41 p.

8. Chemical quality of irrigation waters in northwestern Kansas, by L.R. Hathaway, T.C. Waugh, O.K. Galle, and H.P. Dickey, 1979: 45 p.

9. Discharge of saltwater from Permian rocks to major stream-aquifer systems in central Kansas, by Tony Gogel, 1981: $60 \mathrm{p}$.

10. Chemical quality of irrigations waters in the Equusbeds area, south-central Kansas, by L.R. Hathaway, T.C. Waugh, O.K. Galle, and H.P. Dickey, 1981: 45 p.

\section{Ground-Water Series}

1. Geology and ground-water resources of Montgomery County, southeastern Kansas, by H.G. O'Connor, 1974: $12 \mathrm{p}$.

2. Geohydrology of Nemaha County, northeastern Kansas, by J.R. Ward, 1974: $19 \mathrm{p}$.

4. Groundwater management options for the Pawnee Valley of south-central Kansas, by Manoutchehr Heidari, 1982: $56 \mathrm{p}$.

10. January 1989 Kansas water levels and data related to water-level changes, by Margaret Townsend, Nadeem Shaukat, John Healey and Tom McClain, 1989: 127 p.

\section{Irrigation Series}

1. Ground-water resources of Lane and Scott Counties, western Kansas, by E.D. Gutentag and L.E. Stullken, 1976: $37 \mathrm{p}$.

2. Ground-water resources of Greeley and Wichita Counties, western Kansas, by S.E. Slagle and E.C. Weakly, 1976: $21 \mathrm{p}$.

3. Water-resources reconnaissance of Ness County, westcentral Kansas, by E.D. Jenkins and M.E. Pabst, 1977: $26 \mathrm{p}$.

4. Geohydrology of the Great Bend Prairie, south-central Kansas, by S.W. Fader and L.E. Stullken, 1978: 19 p.

5. Water in the Dakota Formation, Hodgeman and northern Ford Counties, southwestern Kansas, by D.H. Lobmeyer and E.C. Weakly, 1979: 41 p.

6. Hydrology and model of North Fork Solomon River Valley, Kirwin Dam to Waconda Lake, north-central Kansas, by D.G. Jorgensen and L.E. Stullken, 1981: $34 \mathrm{p}$.

7. Geohydrology of southwestern Kansas, by E.D. Gutentag, D.H. Lobmeyer, and S.E. Slagle, 1981: $73 \mathrm{p}$. 
8. Geohydrology of sandstone aquifers in southwestern Kansas, by Jack Kume and J.M. Spinazola, 1985: $49 \mathrm{p}$.

\section{Journals}

*1973. Water-level changes in northwestern Kansas, 1950-73, by M.E. Pabst and E.D. Jenkins, October: $14 \mathrm{p}$.

*1974. Water-level changes in west-central Kansas, 1950-74, by M.E. Pabst and E.D. Jenkins, October: $15 \mathrm{p}$.

1976a. Water-level changes in northwestern Kansas, 1950-76, by M.E. Pabst and E.D. Jenkins, December: $20 \mathrm{p}$.

*1976b. Water-level changes in southwestern Kansas, 1940-75, by M.E. Pabst and E.D. Jenkins, May: 26 p.

1977. Water-level changes in west-central Kansas, 1950-77, by M.E. Pabst and E.D. Gutentag, October: $18 \mathrm{p}$.

1979. Water-level changes in southwestern Kansas, 1940-78, by M.E. Pabst and E.D. Gutentag, May: $29 \mathrm{p}$.

\section{Computer Contributions}

7. Application of pattern analysis to the classification of oilfield brines, by E.E. Angino and C.O. Morgan, in Merriam, D.F., ed., Computer applications in the earth sciences-Colloquium on classification procedures, 1966: p. 53-56.

\section{Special Distribution Publications}

10. Water-level changes in Grant and Stanton Counties, 1939-1964, by J.D. Winslow, C.E. Nuzman, and S.W. Fader, 1964: $11 \mathrm{p}$.

18. Water-level change in Grant and Stanton Counties, Kansas, 1939-1965, by C.E. Nuzman and W.R. Meyer, 1965: $11 \mathrm{p}$.

22. Logs of wells and test holes in Sedgwick County, Kansas, by C.W. Lane and D.E. Miller, 1965: 175 p.

29. Electronic simulation of ground-water hydrology in the Kansas River Valley near Topeka, Kansas, by J.D. Winslow and C.E. Nuzman, 1966: 24 p.

33. Notes on the shape of the truncated cone of depression in the vicinity of an infinite well field, by S.W. Fader, 1967: $11 \mathrm{p}$.

37. Water-level changes in Grant and Stanton Counties, Kansas, 1939-1968, by J.D. Winslow, H.E. McGovern, and H.L. Mackey, 1968: 18 p.

*39. FORTRAN IV program for synthesis and plotting of water-quality data, by L.H. Ropes, C.O. Morgan, and J.M. McNellis, 1969: 59 p.
42. FORTRAN IV programs, KANS, for the conversion of General Land Office locations to latitude and longitude coordinates, by C.O. Morgan and J.M. McNellis, 1969: $24 \mathrm{p}$.

43. Stiff diagrams of water-quality data programmed for the digital computer, by C.O. Morgan and J.M. McNellis, 1969: $26 \mathrm{p}$.

45. Modified Piper diagrams by the digital computer, by J.M. McNellis and C.O. Morgan, 1969: 36 p.

47. Application of computer techniques to seepage-salinity surveys in Kansas, by R.B. Leonard and C.O. Morgan, 1970: $44 \mathrm{p}$.

*48. Brief descriptions of and examples of output from computer programs developed for use with water data in Kansas, by B.H. Lowell, C.O. Morgan, and J.M. McNellis, 1970: 54 p.

\section{Volumes}

*11, pt. 3. Ground-water resources of Chase County [Kansas], by H.G. O'Connor, 1951: p. 28-49.

12, pt. 3. Ground-water resources of Lyon County [Kansas], by H.G. O'Connor, 1953: p. 35-59.

13, pt. 3. Ground-water resources of Osage County [Kansas], by H.G. O'Connor, 1955: p. 28-49.

14, pt. 3. Ground-water resources of Elk County, Kansas, by C.K. Bayne, 1958: p. 37-56.

\section{M-Series Maps}

*4. General availability of ground water in Kansas, by C.K. Bayne and J.R. Ward, compilers, 1967: 1 sheet, scale $1: 500,000$.

5. Saturated thickness and specific yield of Cenozoic deposits in Kansas, by C.K. Bayne and J.R. Ward, 1969: 1 sheet, scale 1:500,000.

\section{Open-File Reports}

40-10. Memorandum in regard to the possibility of leakage of the reservoir basin of the proposed Sedgwick County Lake, in south-central Kansas, by B.F. Latta, 1940: $11 \mathrm{p}$.

48-7. Preliminary report on the ground-water resources of Labette County, Kansas, by G.C. Prescott, Jr., 1948: $15 \mathrm{p}$.

56-4. The ground-water resources of the Prairie Dog Valley area in Kansas, by C.R. Johnson, 1956: 171 p.

73-9. Geohydrology for urban planning in Johnson County, northeastern Kansas, by H.G. O'Connor, 1973: 41 p.

77-5. The Theis equation-Evaluation, sensitivity to storage and transmissivity, and automated fit of pump test data, by C.D. McElwee, 1977: $38 \mathrm{p}$. 
91-12. January 1990 Kansas water levels and data related to water-level changes, by R.W. Buddemeier, Saeed Shamsnia, John Woods, and T.J. McClain, 1991: $129 \mathrm{p}$.

ND-27. Geology and hydrology of the Kanopolis Unit in Ellsworth, McPherson, and Saline Counties, Kansas, by W.D. Waterman, with a section on The chemical quality of the water, by R.A. Krieger, 1952: $186 \mathrm{p}$.

\section{Miscellaneous Publications}

Denne, J.E., 1979, Uncovering buried valleys in northeastern Kansas: Kansas Geological Survey, The Journal, v. 1, no. 3, 4 p.

*Frye, J.C., and Fishel, V.C., 1949, Ground water in southwestern Kansas: Kansas Geological Survey Miscellaneous Publication, 24 p.

\section{Kansas Water Commission}

*Surface waters of Kansas, 1895-1919, by R.C. Rice, 1920: $463 \mathrm{p}$.

*Surface waters of Kansas, 1919-1924, by H.B. Kinnison, 1925: $259 \mathrm{p}$.

\section{Kansas Water Office}

(formerly Kansas Water Resources Board)

\section{Bulletins}

4. Development of a balanced stream-gaging program for Kansas, by L.W. Furness, 1957: 50 p.

6. A program of fluvial sediment investigations in Kansas, by J.C. Mundorff, 1961: $48 \mathrm{p}$.

7. Fluvial sediment in the lower Kansas River Basin-A progress report 1957-60, by J.C. Mundorff and C.H. Scott, 1964: $67 \mathrm{p}$.

8. A general classification of source areas of fluvial sediment in Kansas, by D.L. Collins, 1965: 21 p.

10. Total sediment discharge of selected streams in Kansas 1957-65, a compilation, by C.D. Albert, 1969: 8 p.

12. Evaluation of the surface-water data program in Kansas, by P.R. Jordan and E.R. Hedman, 1970: 49 p.

17. Natural and artificial ground-water recharge, Wet Walnut Creek, central Kansas, by J.B. Gillespie and S.E. Slagle, 1972: 94 p.

19. Fluvial sediment in the Arkansas River Basin, Kansas, by W.R. Osterkamp, 1977: $91 \mathrm{p}$.

20. Artificial-recharge experiments near Lakin, western Kansas, by J.B. Gillespie, G.D. Hargadine, and M.J. Stough, 1977: $91 \mathrm{p}$.

21. Effect of channel sediment on width-discharge relations, with emphasis on streams in Kansas, by W.R. Osterkamp, 1978: $25 \mathrm{p}$.
25. Rainfall-runoff relations and expected streamflow in western Kansas, by P.R. Jordan, 1982: 42 p.

26. Evaluation of techniques for estimating ground-water withdrawals for irrigation in western Kansas, by C.H. Baker, Jr., 1983: 14 p.

\section{Technical Reports}

1. Kansas streamflow characteristics, part 1, Flow duration, by L.W. Furness, 1959: 213 p.

2. Kansas streamflow characteristics, part 2, Low-flow frequency, by L.W. Furness, 1960: 179 p.

3. Kansas streamflow characteristics, part 3, Flood frequency, by D.W. Ellis and G.W. Edelen, Jr., 1960: $221 \mathrm{p}$

4. Kansas streamflow characteristics, part 4, Storage requirements to sustain gross reservoir outflow, by L.W. Furness, 1962: 177 p.

5. Kansas streamflow characteristics, part 5, Storage requirements to control high flow, by L.W. Furness, C.V. Burns, and M.W. Busby, 1964: 169 p.

6A. Kansas streamflow characteristics, part 6A, Base flow data, by M.W. Busby and G.W. Armentrout, 1965: 207 p.

6B. Kansas streamflow characteristics, part 6B, Base flow distribution, by L.W. Furness, C.V. Burns, and M.W. Busby, 1966: $139 \mathrm{p}$.

7. Kansas streamflow characteristics, part 7, Annual streamflow summary tables, by C.V. Burns, 1967: $18 \mathrm{p}$.

8. Kansas streamflow characteristics, part 8 , In-channel hydraulic geometry of streams in Kansas, by C.V. Burns, 1971: $31 \mathrm{p}$.

9. Kansas streamflow characteristics, part 9, Mean annual runoff as related to channel geometry of selected streams in Kansas, by E.R. Hedman and W.M. Kastner, 1972: $25 \mathrm{p}$.

10. Kansas streamflow characteristics, part 10 , Selected streamflow characteristics as related to active-channel geometry of streams in Kansas, by E.R. Hedman, W.M. Kastner, and H.R. Hej1, 1974: 21 p.

11. Kansas streamflow characteristics, magnitude and frequency of floods in Kansas, unregulated streams, by P.R. Jordan and T.J. Irza, 1975: 34 p.

12. Kansas streamflow characteristics, temperatures of Kansas streams, by C.V. Burns, 1975: 220 p. 
13. Kansas streamflow characteristics, physical and climatic characteristics along Kansas streams, by C.V. Burns, D.V. Maddy, P.R. Jordan, and J.M. McNellis, 1976: $41 \mathrm{p}$.

14A. Statistical summary of streamflow data for Kansas streams in the Arkansas River Basin, by P.R. Jordan, 1978: $206 \mathrm{p}$.

14B. Statistical summary of streamflow data for Kansas streams in the Missouri River Basin, by P.R. Jordan, 1979: $334 \mathrm{p}$.

15. Channel geometry of regulated streams in Kansas as related to mean discharge, 1970-80, by W.R.

Osterkamp and E.R. Hedman, 1981: 32 p.

16. Storage requirements to sustain gross reservoir outflow from small basins in Kansas, by W.J. Carswell, Jr., 1982: $40 \mathrm{p}$.

17. Magnitude and frequency of low flows of unregulated streams in Kansas, and estimation of flow-duration curves for ungaged sites, by P.R. Jordan, 1983: $55 \mathrm{p}$.

\section{Progress Reports}

Gillespie, J.B., Green, D.W., and Slagle, S.E., 1970, Artificial ground-water recharge, Wet Walnut Creek, central Kansas-Progress report number two: Kansas Water Resources Board, $28 \mathrm{p}$.

Gillespie, J.B., Lindskov, K.L., and Slagle, S.E., 1969, Artificial ground-water recharge, Wet Walnut Creek-Progress report number one: Kansas Water Resources Board, 22 p.

\section{Kansas Water News}

1958. Sediment studies in Kansas, 1957-1958, by J.C. Mundorff: v. 2, no. 1, p. 6-7.

1962a. Chemical quality program in Kansas, by A.M. Diaz: v. 5, no. 3, p. 3-5.

1962b. Quality of water investigation in the Walnut River Basin, by A.M. Diaz: v. 5, no. 3, p. 6-7.

1962c. Sediment investigations in Kansas, by C.D. Albert: v. 5 , no. 4 , p. 5-7.

1964. Cooperative water-quality investigations of the WaInut River Basin, by R.B. Leonard: v. 7, no. 5, p. 5-6.

1965. Cooperative water-quality investigation, South Fork Ninnescah Basin, by A.M. Diaz: v. 8, no. 3, p. 3-4.

1969. Time of travel study on the Big Blue River, by R.B. Leonard: v. 12 , no. 3, p. 7-8.

1978. Loss of high flows by seepage from stream channels in Kansas, by P.R. Jordan: v. 21 , nos. 1 and 2 , p. $30-34$.

\section{State Water Plan Studies}

Kansas Water Board, 1958-62, State water plan studies, Part A-Preliminary appraisal of Kansas water problems:

Sec. 1, Marais des Cygnes Unit, June 1958, 189 p.

Sec. 2, Cimarron Unit, Sept. 1958, 124 p.

Sec. 3, Kansas Unit, June 1959, 193 p.

Sec. 4, Lower Arkansas Unit, Jan. 1960, 177 p.

Sec. 5, Walnut-Verdigris Unit, June 1960, 160 p.

Sec. 6, Upper Republican Unit, June 1960, 111 p.

Sec. 7, Neosho Unit, June 1961, 134 p.

Sec. 8, Solomon-Saline Unit, June 1961, 154 p.

Sec. 9, Lower Republican Unit, June 1961, 99 p.

Sec. 10, Missouri Unit, June 1962, 109 p.

Sec. 11, Upper Arkansas Unit, June 1962, 121 p.

Sec. 12, Smoky Hill Unit, June 1962, 125 p.

\section{Scientific Journal Articles}

Adams, C.D., Randtke, C.D., Thurman, E.M., and Hulsey, R.A., 1990, Atrazine and its degradation products in soil and ground water, and the effectiveness of water-treatment processes for their removal, in Proceedings from the 40th Annual University of Kansas Environmental Engineering Conference, Lawrence, Kans., February 7, 1990: Lawrence, University of Kansas, Department of Environmental Engineering, $24 \mathrm{p}$.

Adams, C.D., and Thurman, E.M., 1991, Formation and transport of deethylatrazine in the soil and vadose zone: Journal of Environmental Quality, v. 20, no. 3, July-September 1991, p. 540-547.

Aga, D.S., and Thurman, E.M., 1993a, Chromatographic application of solid-phase extraction in developing immunoassay methods for herbicides and their metabolites-An example for alachlor and alachlorethansulfonic acid [abs.], in Programs and proceedings of symposium on agricultural nonpoint sources of contaminants-Focus on herbicides, Lawrence, Kans., September 28-29, 1993: U.S. Environmental Protection Agency, Region VII, and U.S. Geological Survey, p. 38.

1993b, Coupling solid-phase extraction (SPE) and enzyme-linked immunosorbent assay (ELISA) for ultratrace analysis of herbicides in pristine water: Analytical Chemistry, October 1993, v. 65, p. 2894-2898.

Aga, D.S., Thurman, E.M., and Pomes, M.L., 1994, Determination of alachlor and its ethanesulfonic acid metabolite in water by solid-phase extraction and enzyme-linked immunosorbent assay: Analytical Chemistry, v. 66, no. 9, May 1, 1994, p. 1495-1499. 
Albin, D.R., 1975, Water resources alternative study areas, proposed Prairie National Park, Kansas-Oklahoma, in Preliminary environmental assessment, alternative study areas, proposed Prairie National Park, KansasOklahoma (appendix D): U.S. Department of Interior, National Park Service, $32 \mathrm{p}$.

Barnes, Philip, and Perry, C.A., 1990, Herbicide transport in runoff from agricultural fields in Kansas: Proceedings of 7th Annual Water and the Future of Kansas Conference, Manhattan, Kans., March 7-8, 1990, p. 23-24.

Brown, D.E., Meyer, M.T., Pomes, M.L., Thurman, E.M., and Goolsby, D.A., 1990, Temporal variations of triazine and chloroacetanilide herbicide concentrations in selected streams in the midwestern United States, in Abstracts for the AGU Fall Meeting, December 3-7, 1990, San Francisco, Calif.: EOS, Transactions of the American Geophysical Union, v. 71 , no. 43 , October 23,1990 , p. 1331.

Cromwell, A.E., and Thurman, E.M., 1993, Herbicide transport and degradation in a pristine watershed-The fate of herbicides deposited by precipitation [abs.], in Programs and proceedings of symposium on agricultural nonpoint sources of contaminants-Focus on herbicides, Lawrence, Kans., September 28-29, 1993: U.S. Environmental Protection Agency, Region VII, and U.S. Geological Survey, p. 17.

Culbertson, D.M., 1963, Coordinated water-quality investigations in Kansas: 130th Meeting, Missouri Basin Inter-Agency Commission, $12 \mathrm{p}$.

Dabiri, H.E., Green, D.W., and Winslow, J.D., 1970, Digital computer simulation of an aquifer, in Proceedings of Summer Computer Simulation Conference, Denver, Colo., June 10-12, 1970, p. 944-954.

Dankwardt, Andrea, Hock, Bertold, and Thurman, E.M., 1993, Comparison of enzyme-linked immunosorbent assay and gas chromatography/mass spectrometry for the analysis of atrazine in rainwater of Germany [abs.], in New separation and detection methods, Programme and Organisation Abstracts, New Swiss Chemical Society, Basel Switzerland, October 19-20, 1993: New Swiss Chemical Society, $2 \mathrm{p}$.

Dealy, M.T., Kume, Jack, and Jenkins, E.D., 1984, Hydrogeology and development of the Dakota aquifer in southwest Kansas, in Jorgensen, D.G., and Signor, D.C., eds., Geohydrology of the Dakota aquifer: National Water Well Association, Proceedings of the First C.V. Theis Conference on Geohydrology, Lincoln, Nebr., October 5-6, 1982, p. 209-220.
Dingman, R.J., and Angino, E.E., 1969, Chemical composition of selected Kansas brines as an aid to interpreting change in water chemistry with depth: Chemical Geology, Amsterdam, v. 4, p. 325-339.

Durum, W.H., 1953, Relationship of the mineral constituents in solution to streamflow, Saline River near Russell, Kansas: EOS, Transactions of the American Geophysical Union, v. 34, no. 3, p. 435-442.

Ehlig, Christine, and Halepaska, J.C., 1976, A numerical study of confined-unconfined aquifers including effects of delayed yield and leakage: American Geophysical Union, Water Resources Research, v. 12, no. 6, p. $1175-1183$.

Fallon, J.D., and Thurman, E.M., 1993, Determining the age, transport, and three-dimensional distribution of atrazine in a reservoir by immunoassay [abs.], in Programs and proceedings of symposium on agricultural nonpoint sources of contaminants-Focus on herbicides, Lawrence, Kans., September 28-29, 1993: U.S. Environmental Protection Agency, Region VII, and U.S. Geological Survey, p. 13.

Fan, Jian, Wolock, D.M., and Lawrence, Gregory, 1994, Using GIS to study the spatial relation between watershed topography and stream chemistry in the Neversink River Basin, New York [abs.]: EOS, Transactions of the American Geophysical Union, v. 75 , no. 16 , unnumbered page.

Fishel, V.C., 1947a, Ground-water resources of Kansas: Transactions of the Kansas Academy of Science, v. 50, no. 2, p. 105-114.

1947b, Methods used in ground-water investigations in Kansas: Geological Society of America Bulletin, v. 58 , no. 12 , pt. 2 , p. 1273.

1956, Long-term trends of ground-water levels in the United States: Transactions of the American Geophysical Union, v. 37, no. 4, p. 429-435.

Furness, L.W., 1965, Discussion of areal variations of mean annual runoff: American Society of Civil Engineers Proceedings 4304, May, p. 336-341.

Goolsby, D.A., and Thurman, E.M., 1990, Pesticides in streams in the upper midwestern United States: Proceedings of 7th Annual Water and the Future of Kansas Conference, Manhattan, Kans., March 7-8, 1990, p. 27-28.

Goolsby, D.A., Thurman, E.M., Clark, M.L., and Pomes, M.L., 1990, Immunoassay as a screening tool for triazine herbicides in streams-Comparison with gas chromatographic/mass spectrometric methods, in Vanderlaan, Martin, Stanker, L.H., Watkins, B.E., and Roberts, D.W., eds., Immunoassays for trace chemical analysis: American Chemical Society Symposium Series 451 , chap. 8, p. 86-99. 
Goolsby, D.A., Thurman, E.M., and Kolpin, D.W., 1991, Herbicides in streams-Midwestern United States: Irrigation and Drainage, Proceedings of 1991 National Conference, American Society of Civil Engineers, July 22-26, 1991, Honolulu, Hawaii, p. 17-23.

Helgesen, J.O., 1990, Effects of agricultural and petroleum-production land use on water quality in the High Plains aquifer, south-central Kansas [abs.]: Ground Water, v. 28, no. 5, p. 795.

1991, Effects of land use on ground-water quality, south-central Kansas [abs.]: Proceedings of 8th Annual Water and the Future of Kansas-Water in Conflict, Manhattan, Kans., March 4-5, 1991, p. 40.

Helgesen, J.O., Jorgensen, D.G., Leonard, R.B., and Signor, D.C., 1982, Regional study of the Dakota aquifer (Darton's Dakota revisited): Ground Water, v. 20 , no. 4 , p. $410-414$.

Helgesen, J.O., and Leonard, R.B., 1988, Geohydrology of the Great Plains aquifer system, central United States, in Abstracts of Twenty-Fourth Annual Conference, Water Years Ahead-Quality and Quantity, 1990 and Beyond: American Water Resources Association, Milwaukee, Wisc., November 6-8, 1988, p. 49.

1989, Geohydrology of the Great Plains aquifer system, central United States, in Swain, L.A., and Johnson, A.I., eds., Regional aquifer systems of the United States-Aquifers of the midwestern area: American Water Resources Association, AWRA Monograph Series No. 13, p. 179-190.

Helgesen, J.O., and Perry, C.A., 1990, Occurrence of pesticides in Kansas ground water [abs.]: Proceedings of 7 th Annual Water and the Future of Kansas Conference, Manhattan, Kans., March 7-8, 1990, p. 22.

Helgesen, J.O., and Thurman, E.M., 1988, Trace organic compounds in ground water in south-central Kansas as inferred from gas chromatography with flameionization detection, in Preprints of papers presented at the 196th ACS National Meeting: American Chemical Society, Los Angeles, Calif., September 25-30, 1988, v. 28 , no. 2 , p. $9-12$.

Imes, J.L., 1989, Geohydrology and hydrochemistry of the Ozark Plateaus aquifer system, in Swain, L.A., and Johnson, A.I., eds., Regional aquifer systems of the United States, Aquifers of the midwestern area: American Water Resources Association Monograph Series 13, p. 165-178.

Jordan, P.R., 1977, Streamflow transmission losses in western Kansas: Proceedings, American Society of Civil Engineers, Hydraulics Division Journal, v. 103, no. HY8, p. 905-919.
Jorgensen, D.G:, 1988, Estimating permeability in water-saturated formations: The Log Analyst, November-December 1988, p. 401-409.

1989, Paleohydrology of the Anadarko Basin, central United States, in Johnson, K.S., ed., Anadarko Basin Symposium, 1988: Oklahoma Geological Survey Circular 90, p. 176-193.

Jorgensen, D.G., Gogel, Tony, and Signor, D.C., 1982, Determination of flow in aquifers containing variabledensity water, in Ground Water Monitoring Review: Worthington, Ohio, Water Well Journal Publishing Co., v. 2 , no. 2 , Spring 1982 , p. 40-45.

Jorgensen, D.G., Signor, D.C., and Imes, J.L., 1989a, Accounting for intracell flow in models with emphasis on water table recharge and stream-aquifer interaction-I. Problems and concepts: Water Resources Research, v. 25, no. 4, April 1989, p. 669-676.

1989b, Accounting for intracell flow in models with emphasis on water table recharge and stream-aquifer interaction-2. A procedure: Water Resources Research, v. 25, no. 4, April 1989, p. 677-684.

Juracek, K.E., 1991, Application of geographic information system technology to ground-water management in Kansas: Program of abstracts, 36th Annual Midwest Ground Water Conference, Indianapolis, Ind., October 9-11, 1991, p. 74.

1992a, Determining water availability in Kansas: Geo Info Systems, v. 2, no. 8, p. 52-57.

$1992 b$, The utility of geographic information system technology for addressing the effect of agricultural pesticide use on surface-water quality: Proceedings of 9th Annual Water and the Future of Kansas Conference, Manhattan, Kans., March 4-5, 1992, p. 29-30.

1994, Interactive query of State water-appropriations and water-use information: Geo Info Systems, November/December 1994, p. 44-48.

Juracek, K.E., and Kenny, J.F., 1993, Management and analysis of water-use data using a geographic information system: Water Resources Bulletin, v. 29, no. 6, p. 973-979.

1993b, Management and analysis of water-use data using a geographic information system, in Harlin, J.M., and Lanfear, K.J., eds., Geographic information systems and water resources: American Water Resources Association, Proceedings, p. 483-490, 627-628.

Kenny, J.F., and McCauley, J.R. 1982, Remote-sensing investigations in the coal fields of southeastern Kansas, in Johannsen, C.J., and Sanders, J.L., eds., chap. 29 of Remote sensing for resource management, (outgrowth of a national conference by the same name, held October 28-30, 1980, at Kansas City, Mo., 665 p.): Ankeny, Iowa, Soil Conservation Society of America, p. 338-346. 
Leahy, P.P., and Stamer, J.K., 1994, Herbicides in the lower Kansas River Basin-Policy relevant findings from the U.S. Geological Survey's National WaterQuality Assessment [abs.]: Program of 1994 Annual Meeting of the Geological Society of America, Seattle, Wash., October 24-27, 1994, p. A-106.

Leonard, R.B., Signor, D.C., Jorgensen, D.G., and Helgesen, J.O., 1983, Geohydrology and hydrochemistry of the Dakota aquifer, central United States: American Water Resources Association, Water Resources Bulletin, v. 19, no. 6, December 1983, p. 903-911.

Lohman, S.W., and Frye, J.C., 1940, Geology and groundwater resources of the Equus-beds area in south-central Kansas: Economic Geology, v. 35, no. 7, p. 839-866.

McClain, T.J., and Jenkins, E.D., 1971, Digital simulation of the Ogallala aquifer in Sherman County, northwestern Kansas, in Ogallala Aquifer Symposium: Texas Tech University Special Report 39, p. 72-88.

McElwee, C.D., and Yukler, M.R., 1978, Sensitivity of ground-water models with respect to variations in transmissivity and storage: American Geophysical Union, Water Resources Research, v. 14, no. 3, p. $451-459$.

McGovern, H.E., 1971, Geology and ground water in the Ogallala Formation and undifferentiated Pleistocene deposits, southwestern Kansas, in Ogallala Aquifer Symposium: Texas Tech University Special Report 39, p. 15-29.

1984, Overview of the Dakota aquifer in Kansas, in Jorgensen, D.G., and Signor, D.C., eds., Geohydrology of the Dakota aquifer: National Water Well Association, Proceedings of First C.V. Theis Conference on Geohydrology, Lincoln, Nebr., October 5-6, 1982, p. 58-61.

McNellis, J.M., Morgan, C.O., and Lowell, B.H., 1968, Digital computer applications that facilitate collection and interpretation of ground-water data, in International Association Scientific Hydrology, The use of analog and digital computers in hydrology-A symposium: International Association Scientific Hydrology Publication No. 81 A1HS, v. 2, p. 561-568.

1969, Computer-produced tables, maps, and diagrams as tools in the interpretation of brine data from southeastern Kansas (U.S.A.): Chemical Geology, Amsterdam, v. 4, p. 303-324.

Meyer, M.T., Mills, M.S., and Thurman, E.M., 1993, Automated solid-phase extraction of herbicides from water for gas chromatographic/mass spectrometric analysis: Journal of Chromatography, v. 629, p. 55-59.

Meyer, M.T., and Thurman, E.M., 1993a, Cyanazine metabolites in surface water-The transport and degradation of labile herbicides [abs.], in Proceedings of spring meeting, American Geophysical Union, Mineralogical Society of America, and Geochemical Society, Baltimore, Md., May 24-28, 1993: EOS, Transactions of the American Geophysical Union, April 20, 1993, p. 135.

1993b, Cyanazine metabolites in surface water-The transport and degradation of labile herbicides [abs.], in Programs and proceedings of symposium on agricul-tural nonpoint sources of contaminants-Focus on herbicides, Lawrence, Kans., September 28-29, 1993: U.S. Environmental Protection Agency, Region VII, and U.S. Geological Survey, p. 21.

Mills, M.S., and Thurman, E.M., 1992, Mixed-mode isolation of triazine metabolites in soil and aquifer sediments using automated solid-phase extraction: Analytical Chemistry, v. 64, p. 1985-1990.

1994a, Preferential dealkylation of s-triazine herbicides in the unsaturated zone: Environmental Science and Technology, v. 28, no. 4, p. 600-605.

1994b, Reduction of nonpoint source contamination of surface water and groundwater by starch encapsulation of herbicides: Environmental Science and Technology, v. 28, no. 1, p. 73-79.

Mills, M.S., Thurman, E.M., and Patel, Ragina, 1991, Isolation of polar metabolites of atrazine by mixedmode adsorption: Abstracts of papers presented at 1991 Pittsburgh Conference \& Exposition on Analytical Chemistry and Applied Spectrometry, Chicago, Ill., March 3-8, 1991, p. 982.

Mills, M.S., Thurman, E.M., and Pedersen, M.J., 1993, Application of mixed-mode, solid-phase extraction in environmental and clinical chemistry-Combining hydrogen-bonding, cation-exchange and Van der Waals interactions: Journal of Chromatography, v. 629, p. 11-21.

Mills, M.S., Thurman, E.M., and Wing, R.E., 1990, Dissipation of starch-encapsulated herbicides-A field comparison with powdered herbicides, in Abstract for the AGU Fall Meeting, December 3-7, 1990, San Francisco, Calif.: EOS, Transactions of the American Geophysical Union, v. 71, no. 43, October 23, 1990, p. 1331-1332.

Morgan, C.O., Dingman, R.J., and McNellis, J.M., 1966, Digital computer methods for water-quality data: Ground Water, Technical Division Journal, National Water Well Association, v. 4, no. 3, July, p. 35-42.

Morgan, C.O., and McNellis, J.M., 1971, Reduction of lithologic-log data to numbers for use in the digital computer: Mathematical Geology, v. 3, no. 1, p. 79-86. 
Myers, N.C., 1992, Chloride distribution in the alluvial aquifer adjacent to the Arkansas River between Hutchinson and Wichita, south-central Kansas: Kansas Academy of Science, Abstracts of Papers Presented at 124th Annual Meeting, Hutchinson, Kans., March 26-27, 1992, v. 11, p. 33.

O'Connor, H.G., 1949, Notes on the ground-water resources of Chase County, Kansas: Transactions of the Kansas Academy of Science, v. 52, no. 3, p. 399-405.

Osterkamp, W.R., 1978a, Bed- and bank-sampling procedure at channel geometry sites: Proceedings of National Conference on Sampling, Validation, and Quality Control of Environmental Measurements, Atlanta, Ga., May 31-June 2, 1978.

1978b, Gradient, discharge, and particle-size relations of alluvial channels in Kansas, with observations on braiding: American Journal of Science, v. 278, November 1978, p. 1253-1268.

1979a, Bed- and bank-material sampling procedure at channel-geometry sites: National Conference on Quality Assurance of Environmental Measurement, Information Transfer Inc., p. 86-89.

1979b, Invariant power functions as applied to fluvial morphology, in Rhodes, D.D., and Williams, G.R., eds., Adjustments of the fluvial system: Kendall/Hunt Publishing Co., p. 33-54.

1980, Sediment-morphology relations of alluvial channels: American Society Civil Engineers Proceedings, Watershed Management Symposium, Boise, Idaho, $12 \mathrm{p}$.

Osterkamp, W.R., and Hedman, E.R., 1977, Variation of width and discharge for natural high-gradient stream channels: American Geophysical Union, Water Resources Research, v. 13, no. 2, p. 256-258.

1979, Discharge estimates in surface-mine areas using channel-geometry techniques: Proceedings, Symposium on Surface-Mine Hydrology, Sedimentology and Reclamation, University of Kentucky Bulletin 119, p. 43-49.

Perry, C.A., 1981, Regional precipitation periodicity, in Proceedings of Fourth Conference on Hydrometeorology, Reno, Nev., October 7-9, 1981: American Meteorological Society, session 1B, p. 45-50.

1987, Solar-activity harmonics and world climate [abs.]: EOS, Transactions of the American Geophysical Union, v. 68, no. 44, November 3, 1987, p. 1269.

1990a, A solar-luminosity model and climate, in Schatten, K.H., and Arking, Albert, eds., Climate impact of solar variability: National Aeronautics and Space Administration, NASA Conference Publication 3086, p. 181-188. 1990b, Speculation on a solar chronometer for climate, in Schatten, K.H., and Arking, Albert, eds., Climate impact of solar variability: National Aeronautics and Space Administration, NASA Conference Publication 3086, p. 357-364.

1991a, A Pleistocene/Holocene climatic model [abs.]: Symposia, Institute for Tertiary-Quatemary Studies, University of Kansas, Lawrence, Kans., February 28-March 1, 1991, unnumbered page.

1991b, A solar-luminosity/oceanic/atmospheric mechanism for regional climate: National Science Foundation, Workshop on Solar-Terrestrial Impacts on Global Change, Boulder, Colo., May 8-10, 1991, unnumbered page.

1991c, Annual precipitation estimates-1 to 4 years in advance [abs.], in Program of Federal Forecasters Conference/1991, Washington, D.C., September 12, 1991: U.S. Department of Agriculture, p. 13.

1991d, Future water availability [abs.]: Proceedings of 8th Annual Water and the Future of Kansas-Water in Conflict, Manhattan, Kans., March 4-5, 1991, p. 42.

1991e, Recent precipitation patterns in the United States as related to solar-irradiance variations: AGU Program and Abstracts, 1991 Fall Meeting, December 9-13, 1991, p. 69.

1992a, A correlation between precipitation in the western United States and solar-irradiance variations: American Water Resources Association, Proceedings of 28th Annual Conference \& Symposium on Managing Water Resources During Global Change, Reno, Nev., November 1-5, 1992, p. 721-729.

1992b, Annual precipitation estimates -1 to 4 years in advance, in Papers and Proceedings of Federal Forecasters Conference/1991: Washington, D.C., September 12, 1991, p. 134-135.

1992c, The future of rainfall in Kansas [abs.]: Proceedings of 9th Annual Water and the Future of Kansas Conference, Manhattan, Kans., March 4-5, 1992, p. 36.

1993a, A mechanism for the link between solarirradiance variations and regional precipitation, in Redmond, K.T., and Tharp, V.L., eds., Proceedings of the Nineth Annual Pacific Climate (PACLIM) Workshop, Asilomar, Calif., April 21-24, 1992: California Department of Water Resources, Interagency Ecological Studies Program, Technical Report 34, p. 97-102.

1993b, A solar-weather mechanism: World Meteorological Organization Bulletin, v. 42, no. 2, p. 123-129. 
1994, Solar-irradiance variations and regional precipitation fluctuations in the western USA: International Journal of Climatology, v. 14, November 1994, p. 969-983.

Perry, C.A., and Barnes, P.L., 1990, A comparison of concentrations and mass of herbicides in runoff from test plots using conventional and minimum-tillage practices, Kansas River Valley, in Abstracts of the AGU Fall Meeting, December 3-7, 1990, San Francisco, Calif.: EOS, Transactions of the American Geophysical Union, v. 71, no. 43, October 23, 1990, p. 1331.

Perry, C.A., and Hart, R.J., 1985, Installation of observation wells on hazardous-waste sites in Kansas using a hollow-stem auger: Ground Water Monitoring Review, Fall 1985, v. 5, no. 4, p. 70-73.

Perry, C.A., and others, 1993, Detection of fractures in Ash Meadows, southwestern Nevada by electromagnetic terrain-conductivity measurements, in Proceedings SPIE-The International Society for Optical Engineering, Ground Sensing, Orlando, Fla., April 14, 1993, v. 1941, p. 113-124.

Perry, C.A., and Studley, S.E., 1994, Effect of flood control reservoirs on peak discharges along the Kansas River, 1993 [abs.]: EOS, Transactions of the American Geophysical Union, v. 74, no. 43, p. 61.

Plummer, L.N., Michel, R.L., Thurman, E.M., and Glynn, P.D., 1993, Environmental tracers for age dating young ground water, in Alley, W.M., ed., Regional groundwater quality: New York, Van Nostrand Reinhold, p. 255-294.

Pomes, M.L., Holub, D.G., Aga, D.S., and Thurman, E.M., 1993, Isocractic separation of alachlor ethane-sulfonic acid, alachlor oxacetic acid, and hydroxy-atrazine by reversed-phase liquid chromatography [abs.], in Programs and proceedings of symposium on agricultural nonpoint sources of contaminants-Focus on herbicides, Lawrence, Kans., September 28-29, 1993: U.S. Environmental Protection Agency, Region VII, and U.S. Geological Survey, p. 37.

Pomes, M.L., and Thurman, E.M., 1990, Comparison of microtitre-plate immunoassay (ELISA) and gas chromatography/mass spectrometry (GC/MS) for analysis of herbicides in stormflow samples, in Abstracts of AGU Fall Meeting, December 3-7, 1990, San Francisco, Calif.: EOS, Transactions of the American Geophysical Union, v. 71, no. 43, October 23, 1990, p. 1331.

1991, Comparison of microtitre-plate immunoassay (ELISA) and gas chromatography/mass spectrometry (GC/MS) for analysis of herbicides in storm runoff samples [abs.]: Proceedings of 8 th Annual Water and the Future of Kansas-Water in Conflict, March 4-5, 1991, p. 43.

Pomes, M.L., Thurman, E.M., and Tate, C.M., 1991, Variation of dissolved-organic-carbon concentrations in soil waters from a tall-grass prairie and galley-forest watershed, northeast Kansas: AGU Program and Abstracts, 1991 Fall Meeting, December 9-13, 1991, p. 205-206.

Pope, L.M., and Hess, L.G., 1989, Load-detention efficiencies in a dry-pond basin, in Roesner, L.A., Urbonas, Ben, and Sonnen, M.B., eds., Design of urban runoff quality controls: Proceedings of Engineering Foundation Conference on Current Practice and Design Criteria for Urban Quality Control, Potosi, Mo., July 10-15, 1988, p. 258-267.

Pope, L.M., Jennings, M.E., and Thibodeaux, K.G., 1988, Instrumentation for a dry-pond detention study, in Proceedings of 1988 National Conference on Hydraulic Engineering: American Society of Civil Engineers, Colorado Springs, Colo., August 8-12, 1988, p. 84-89.

Rosenshein, J.S., 1979, Groundwater in the United States 1975-78: American Geophysical Union, Reviews of Geophysics and Space Physics, v. 17, no. 6, September 1979, p. 1240-1253.

1988, Region 18, Alluvial valleys, in Back, William, Rosenshein, J.S., and Seaber, P.R., eds., Hydrogeology: Boulder, Colo., Geological Survey of America, The Geology of North America, v. 0-2, p. 165-175.

Rosenshein, J.S., and Bennett, G.D., eds., 1984, Groundwater hydraulics: American Geophysical Union, Water Resources Monograph 9, 407 p.

Rutledge, A.T., 1988, An axisymetric model to simulate drawdown within and around pumping well [abs.], in Program of International Conference on Advances in Ground-water Hydrology: American Institute of Hydrology, Tampa, Fla., November 16-19, 1988, p. 15.

Scribner, E.A., Thurman, E.M., and Goolsby, D.A., 1993, Reconnaissance data for selected herbicides and their metabolites in surface water of the midwestern United States-Immunoassay and gas chromatography/mass spectrometry [abs.], in Programs and proceedings of symposium on agricultural nonpoint sources of contaminants-Focus on herbicides, Lawrence, Kans., September 28-29, 1993: U.S. Environmental Protection Agency, Region VII, and U.S. Geological Survey, p. 41. 
Signor, D.C., and Imes, J.L., 1989, Geohydrology of regional aquifer systems in Cretaceous and older rocks underlying the central United States, in Swain, L.A., and Johnson, A.I., eds., Regional Aquifer Systems of the United States-Aquifers of the midwestern area: American Water Resources Association, AWRA Monograph Series No. 13, p. 149-163.

Sophocleous, Marios, and Perry, C.A., 1984, Experimental studies in natural ground-water-recharge dynamics-Assessment of recent advances in instrumentation: Journal of Hydrology, v. 70, p. $369-382$.

1985, Experimental studies in natural ground-waterrecharge dynamics-The analysis of observed recharge events: Journal of Hydrology, v. 81, p. 297-332.

Spruill, T.B., 1983, Relationship of nitrate concentrations to distance of well screen openings below casing water levels: American Water Resources Association, Water Resources Bulletin, v. 19, no. 6, December 1983, p. 977-981.

1984, Use of data from regional ground-water quality monitoring networks [abs.]: 29th Annual Midwest Ground-Water Conference, Proceedings, Lawrence, Kans., October 1-3, 1984, p. 12.

1987, A proposed method for design of a network to describe non-normally distributed ground-waterquality characteristics [abs.]: EOS, Transactions of the American Geophysical Union, v. 68, no. 16, April 21, 1987, p. 313.

1988, Use of total organic carbon as an indicator of contamination from an oil refinery, south-central Kansas: Ground Water Monitoring Review, Summer 1988, p. 76-82.

Spruill, T.B., and Candela, Lucila, 1990, Two approaches to design of monitoring networks: Ground Water, v. 28 , no. 3 , p. $430-442$.

Squillace, P.J., and Thurman, E.M., 1992, Herbicide transport in rivers--Importance of hydrology and geochemistry in nonpoint-source contamination: Environmental Science and Technology, v. 26, no. 3, p. 538-545.

Squillace, P.J., Thurman, E.M., and Furlong, E.T., 1993, Groundwater as nonpoint source of atrazine and deethylatrazine in a river during base flow conditions: Water Resources Research, v. 29, no. 6, p. 1719-1729.

Stamer, J.K., 1991, An investigation summary concerning pesticides in lower Kansas River Basin in Kansas and Nebraska [abs.]: Proceedings of 8th Annual Water and the Future of Kansas-Water in Conflict, March 4-5, 1991, p. 45-46.

1992, Distribution of atrazine in surface water, lower Kansas River Basin, Kansas and Nebraska [abs.]:
Proceedings of North Central Weed Science Society, v. 47 , p. 148.

Stamer, J.K., Pope, L.M., and Zelt, R.B., 1990, Occurrence and distribution of pesticides in the lower Kansas River Basin in Kansas and Nebraska: Proceedings of 7th Annual Water and the Future of Kansas Conference, Manhattan, Kans., March 7-8, 1990, p. 25-26.

1990, Occurrence and distribution of pesticides in the inflows and outflows of reservoirs in northeast Kansas: Kansas Academy of Science, Abstracts, v. 9, p. 60.

1991, Areal and temporal distribution of nitrogencontaining herbicides in surface water in the lower Kansas River Basin, Kansas and Nebraska: American Water Resources Association, 27th Annual Conference and Symposium, New Orleans, La.,

September 8-13, 1991, p. 349-350.

1992, Distribution of atrazine and similar nitrogencontaining herbicides, lower Kansas River Basin: U.S Geological Survey Director's Yearbook 1991, p. 76-79.

Stamer, J.K., and Zelt, R.B., 1994, Organonitrogen herbicides in the lower Kansas River Basin: American Water Works Association, v. 86, no. 1, January 1994, p. 93-104.

Thurman, E.M., 1993a, Chemistry, degradation, and transport of triazine metabolites in surface water [abs.], in Proceedings of spring meeting, American Geophysical Union, Mineralogical Society of America, and Geochemical Society, Baltimore, Md., May 24-28, 1993: EOS, Transactions of the American Geophysical Union, April 20, 1993, p. 129.

1993b, Chemistry, degradation, and transport of triazine metabolites in surface water [abs.], in Programs and proceedings of symposium on agricultural nonpoint sources of contaminants-Focus on herbicides, Lawrence, Kans., September 28-29, 1993: U.S. Environmental Protection Agency, Region VII, and U.S. Geological Survey, p. 19.

Thurman, E.M., Goolsby, D.A., Meyer, M.T., and Kolpin, D.W., 1991, Herbicides in surface waters of the midwestern United States-The effect of spring flush: Environmental Science and Technology, October 1991, v. 25, p. 1794-1796.

Thurman, E.M., Goolsby, D.A., Meyer, M.T., Mills, M.S., Pomes, M.L., and Kolpin, D.W., 1992, A reconnaissance study of herbicides and their metabolites in surface water of the midwestern United States using immunoassay and gas chromatography/mass spectrometry: Environmental Science and Techno$\operatorname{logy}$, v. 26, no. 12 , p. 2440-2447. 
Thurman, E.M., Meyer, M.T., Pomes, M.L., Mills, M.S., and Brown, D.E., 1990, Enzyme-linked immunosorbent assay compared with gas chromatography/ mass spectrometry for the determination of triazine herbicides in water, in Abstracts of the AGU Fall Meeting, December 3-7, 1990, San Francisco, Calif.: EOS, Transactions of the American Geophysical Union, v. 71, no. 43, p. 1330.

Thurman, E.M., Meyer, Michael, Pomes, Michael, Perry, C.A., and Schwab, A.P., 1990, Enzyme-linked immunosorbent assay compared with gas chromatography/mass spectrometry for the determination of triazine herbicides in water: Analytical Chemistry, v. 62 , no. 18 , September 15,1990 , p. 2043-2048.

Thurman, E.M., and Mills, M.S., 1991, Herbicide metabolites as indicators of surface- and ground-water interaction: AGU Program and Abstracts, 1991 Fall Meeting, December 9-13, 1991, p. 168.

Thurman, E.M., Squillace, P.J., Strzepek, K.M., and Garcia, L., 1988, Intelligent data analyzer-Herbicide transport in the Cedar River, Iowa, in Preprints of Papers presented at the 196th ACS National Meeting: American Chemical Society, Los Angeles, Calif., September 25-30, 1988, v. 28, no. 2, p. 13-15.

U.S. Geological Survey, 1955, Availability, use, and control of water: Report of the Arkansas-White-Red Basins Inter-Agency Committee, pt. 2, sec. 17, 122 p.

Williams, C.C., and Lohman, S.W., 1947, Methods used in estimating the ground-water supply in the Wichita, Kansas well-field area: EOS, Transactions of the American Geophysical Union, v. 28, no. 1, p. 120-131.

Wolock, D.M., 1993, Effects of topography and subbasin size on simulated flow pathways in Sleepers River watershed, Vermont [abs.]: EOS, Transactions of the American Geophysical Union, v. 74, no. 43, unnumbered page.

Wolock, D.M., and McCabe, G.J., 1993, Effects of climate change on water resources in the Delaware River Basin, in Proceedings of the First National Conference on Climate Change and Water Resources Management, Albuquerque, New Mexico, November 5-7, 1991: U.S. Army Corps of Engineers, p. II-140-II-149.

Wolock, D.M., McCabe, G.J., Jr., Tasker, G.D., and Moss, M.E., 1993, Effects of climate change on water resources in the Delaware River Basin: Water Resources Bulletin, v. 29, no. 3, p. 475-486.

Wolock, D.M., and Price, C.V., 1994, Effects of digital elevation model map scale and data resolution on a topography-based watershed model : Water Resources Research, November 1994, v. 30, no. II, p. 3041-3052.
Zamarripa, G.T., and Perry, C.A., 1993, Multipleregression analysis of climatic factors and Kansas regional precipitation, in Abstract of Papers presented at a Joint Meeting of the Missouri and Kansas Academies of Science, Kansas City, Mo., April 23-24, 1993: Kansas Academy of Science, v. 13 , p. 96.

Zelt, R.B., 1991, GIS technology used to manage and analyze hydrologic information: GIS World, August 1991, p. 70-73.

Zimmerman, L.R., and Thurman, E.M., 1993, Trace analysis of the herbicide 2,4-D in water samples by solid-phase extraction (SPE) and enzyme-linked immunosorbent assay (ELISA) [abs.], in Abstract book of 14th annual meeting-Ecological risk assessment, lessons learned?, Houston, Tex., November 14-18, 1993: Society of Environmental Toxicology and Chemistry, p. 522.

\section{Master's Theses and Doctoral Dissertations}

Adams, C.D., 1991, Ozonation of atrazine-A kinetic model and byproduct formation in natural waters: Lawrence, University of Kansas, Ph.D. dissertation, $242 \mathrm{p}$.

Fallon, J.D., 1994, Determining the 3-dimensional distribution, transport, and relative age of atrazine and selected metabolites in Perry Lake, Kansas: Lawrence, University of Kansas, master's thesis, $176 \mathrm{p}$.

Meyer, M.T., 1994, Geochemistry of cyanazine and its metaboliltes-Indicators of contaminant transport in surface water of the midwestern United States: Lawrence, University of Kansas, Ph.D. dissertation, 362 p.

Mills, M.S., 1991, Field dissipation of encapsulated herbicides-Geochemistry and degradation: Lawrence, University of Kansas, master's thesis, $98 \mathrm{p}$.

1994, The organic geochemistry of natural aquatic foam: Lawrence, University of Kansas, Ph.D. dissertation, $274 \mathrm{p}$.

Perry, C.A., 1994, A solar chronometer for climate-Astronomical and geophysical evidence: Lawrence, University of Kansas, Ph.D. dissertation, 314 p.

Rasmussen, P.P., 1994, The hydrogeology and the groundwater quality conditions at the City of Olathe Landfill: Lawrence, University of Kansas, master's thesis, $90 \mathrm{p}$.

Shamet, K.A., 1992, Surfactants in a natural foamCharacterization and role in enhanced degradation of herbicides: Lawrence, University of Kansas, master's thesis, $83 \mathrm{p}$. 


\section{LISTING BY YEAR OF PUBLICATION}

This index is arranged chronologically by year of publication. After you have located the publication year, citations are listed alphabetically by the author's last name and initials, and then chronologically by publication year. For author listings with more than one publication in a given year, the letters "a," "b," "c," and so forth are added after the year.

\section{6-1899}

*Davis, A.P., 1897, Report of progress of stream measurements for the calendar year 1896: U.S. Geological Survey 18th Annual Report, Part IV, p. $1-418$.

*Gannett, Henry, 1898, A gazetteer of Kansas: U.S. Geological Survey Bulletin 154,246 p.

*Haworth, Eramus, 1897, Underground waters of southwestern Kansas: U.S. Geological Survey WaterSupply Paper 6, 65 p.

*Hay, Robert, 1890, A geological reconnaissance in southwestern Kansas: U.S. Geological Survey Bulletin 57, $49 \mathrm{p}$.

* _ 1895, Water resources of a portion of the Great Plains: U.S. Geological Survey 16th Annual Report, Part II, p. 535-588.

*Newell, F.H., 1895, Report of progress of the Division of Hydrography for 1893 and 1894: U.S. Geological Survey Bulletin 131, $126 \mathrm{p}$.

*__ 1898, Report of progress of stream measurements for the calendar year 1897: U.S. Geological Survey 19th Annual Report, Part IV, p. 1-632.

* $\quad 1899$, Report of progress on stream measurements for the calendar year 1898: U.S. Geological Survey 20th Annual Report, Part IV, p. 1-562.

*Peale, A.C., 1886, Lists and analyses of the mineral springs of the United States (a preliminary study): U.S. Geological Survey Bulletin 32, 235 p.

* _ 1894, Natural mineral waters of the United States: U.S. Geological Survey 14th Annual Report, Part II-B, p. 49-88.

\section{$1900-1919$}

*Darton, N.H., 1905a, Preliminary list of deep borings in the United States: U.S. Geological Survey WaterSupply Paper 149, 175 p.

*__ 1905b, Preliminary report on the geology and underground water resources of the central Great Plains: U.S. Geological Survey Professional Paper 32, $433 \mathrm{p}$.

*Hinds, Henry, and Greene, F.C., 1917, Description of the Leavenworth and Smithville quadrangles, Missouri-
Kansas: U.S. Geological Survey Geologic Atlas, Folio 206, 13 p., 10 pls., 10 figs.

*Johnson, W.D., 1901, The High Plains and their utilization: U.S. Geological Survey 21st Annual Report, Part IV-C, p. 743-768.

*__ 1902, The High Plains and their utilization (conclusion): U.S. Geological Survey 22nd Annual Report, Part IV-C, p. 671-690.

Meinzer, O.E., 1915, Preliminary report on ground water for irrigation in the vicinity of Wichita, Kans.: U.S. Geological Survey Water-Supply Paper 345-A, 9 p.

*Murphy, E.C., 1904, Destructive floods in the United States in 1903, contains Kansas floods and hydrographic data: U.S. Geological Survey Water-Supply Paper 96, 81 p.

*Murphy, E.C., and others, 1905, Destructive floods in the United States in 1904, contains Kansas floods: U.S. Geological Survey Water-Supply Paper 147, $206 \mathrm{p}$.

*Newell, F.H., 1900, Report of progress of stream measurements for the calendar year 1899: U.S. Geological Survey 21st Annual Report, p. 9-488.

*__ 1901, Report of progress of stream measurements for the calendar year 1900: U.S. Geological Survey 22nd Annual Report, p. 9-506.

*Parker, H.N., 1911, Quality of the water supplies of Kansas, with a preliminary report on Stream pollution by mine waters in southeastern Kansas, by E.H.S. Bailey: U.S. Geological Survey Water-Supply Paper 273, 375 p.

*Prosser, C.S., and Beede, J.W., 1904, Description of Cottonwood Falls quadrangle, Kansas: U.S. Geological Survey Geologic Atlas, Folio 109, 6 p., 2 pls.

*Schrader, F.C., 1908, Description of the Independence quadrangle, Kansas: U.S. Geological Survey Geologic Atlas, Folio 159, 7 p., 3 pls.

*Schrader, F.C., and Haworth, Erasmus, 1906, Economic geology of the Independence quadrangle, Kansas: U.S. Geological Survey Bulletin 296, 74 p.

*Slichter, C.S., 1902, The motions of underground waters: U.S. Geological Survey Water-Supply Paper 67, 106 p.

*__ 1906, The underflow in the Arkansas Valley in western Kansas: U.S. Geological Survey WaterSupply Paper $153,90 \mathrm{p}$. 
*Smith, W.S.T., 1905, Water resources of the Joplin district, Missouri-Kansas: U.S. Geological Survey Water-Supply Paper 145, p. 74-83.

*Smith, W.S.T., and Siebenthal, C.E., 1907, Description of the Joplin district, Missouri-Kansas: U.S. Geological Survey Geologic Atlas, Folio 148, 20 p., 27 figs.

*Wolff, H.C., 1911, The utilization of the underflow near St. Francis, Kansas: U.S. Geological Survey WaterSupply Paper 258, p. 98-119.

\section{0-39}

*Clarke, F.W., 1924, The composition of the river and lake waters of the United States: U.S. Geological Survey Professional Paper 135, $133 \mathrm{p}$.

*Darton, N.H., 1920, Description of the Syracuse and Lakin quadrangles, Kansas: U.S. Geological Survey Geologic Atlas, Folio 212, 10 p., 6 pls., 7 figs.

*Follansbee, Robert, and Spiegel, J.B., 1937, Flood on Republican and Kansas Rivers, May and June 1935: U.S. Geological Survey Water-Supply Paper 796-B, p. 21-52.

*Kinnison, H.B., 1925, Surface waters of Kansas, 1919-1924: Kansas Water Commission, 259 p.

*Rice, R.C., 1920, Surface waters of Kansas, 1895-1919: Kansas Water Commission, $463 \mathrm{p}$.

*Theis, C.V., Burleigh, H.P., and Waite, H.A., 1935, Ground water in the southern High Plains: U.S. Department of the Interior Memorandum for the Press, October 1935, 4 p.

1940

${ }^{*}$ Frye, J.C., 1940, A preliminary report on the water supply of the Meade Artesian Basin, Meade County, Kansas: Kansas Geological Survey Bulletin 35, $39 \mathrm{p}$.

Latta, B.F., 1940, Memorandum in regard to the possibility of leakage of the reservoir basin of the proposed Sedgwick County Lake, in south-central Kansas: Kansas Geological Survey Open-File Report 40-10, $11 \mathrm{p}$.

Lohman, S.W., and Frye, J.C., 1940, Geology and groundwater resources of the Equus-beds area in south-central Kansas: Economic Geology, v. 35, no. 7, p. 839-866.

Lohman, S.W., and Mitchell, Alexander, 1940, Memorandum in regard to prospecting for a softer water supply for the Kansas State Penitentiary at Lansing, Kansas: U.S. Geological Survey Open-File Report, $17 \mathrm{p}$.

*Moore, R.C., 1940, Ground-water resources of Kansas (with chapters by S.W. Lohman, J.C. Frye, H.A. Waite, T.G. McLaughlin, and B.F. Latta): Kansas Geological Survey Bulletin 27, $112 \mathrm{p}$.
1941

*Frye, J.C., 1941, Reconnaissance of ground-water resources of Atchison County, Kansas: Kansas Geological Survey Bulletin 38, pt. 9, p. 237-260.

*Latta, B.F., 1941, Geology and ground-water resources of Stanton County, Kansas: Kansas Geological Survey Bulletin 37, $119 \mathrm{p}$.

*Lohman, S.W., 1941, Ground-water conditions in the vicinity of Lawrence, Kansas: Kansas Geological Survey Bulletin 38, pt. 2, 64 p.

\section{2}

*Frye, J.C., 1942, Geology and ground-water resources of Meade County, Kansas: Kansas Geological Survey Bulletin 45, 152 p.

*Lohman, S.W., 1942, Ground-water supplies available for national defense industries in south-central Kansas: Kansas Geological Survey Bulletin 41, pt. 1, 19 p.

*Lohman, S.W., Frye, J.C., Waite, H.A., Fishel, V.C., McLaughlin, T.G., Latta, B.F., and Abernathy, G.E., 1942, Ground-water supplies available in Kansas for national defense industries: Kansas Geological Survey Bulletin 41, pt. 2, p. 21-28.

*McLaughlin, T.G., 1942, Geology and ground-water resources of Morton County, Kansas: Kansas Geological Survey Bulletin 40, 126 p.

*Waite, H.A., 1942, Geology and ground-water resources of Ford County, Kansas: Kansas Geological Survey Bulletin 43, 250 p.

\section{3}

*Frye, J.C., Brazil, J.J., and Stoltenberg, H.A., 1943, Ground water in the oil-field areas of Ellis and Russell Counties, Kansas: Kansas Geological Survey Bulletin 50, $104 \mathrm{p}$.

*McLaughlin, T.G., 1943, Geology and ground-water resources of Hamilton and Kearny Counties, Kansas: Kansas Geological Survey Bulletin 49, 220 p.

1944

*Latta, B.F., 1944, Geology and ground-water resources of Finney and Gray Counties, Kansas: Kansas Geological Survey Bulletin 55, $272 \mathrm{p}$.

*Williams, C.C., 1944, Ground-water conditions in the Neosho River Valley in the vicinity of Parsons, Kansas: Kansas Geological Survey Bulletin 52, pt. 2, p. 29-80. 
*Frye, J.C., 1945, Geology and ground-water resources of Thomas County, Kansas: Kansas Geological Survey Bulletin 59, 110 p.

\section{6}

*McLaughlin, T.G., 1946, Geology and ground-water resources of Grant, Haskell, and Stevens Counties, Kansas: Kansas Geological Survey Bulletin 61, 221 p.

*Williams, C.C., 1946, Ground-water conditions in Arkansas River Valley in the vicinity of Hutchinson, Kansas: Kansas Geological Survey Bulletin 64, pt. 5, p. 145-216.

*Williams, C.C., and Bayne, C.K., 1946, Ground-water conditions in Elm Creek Valley, Barber County, Kansas: Kansas Geological Survey Bulletin 64, pt. 3, p. 77-124.

\section{7}

Fishel, V.C., 1947a, Ground-water resources of Kansas: Transactions of the Kansas Academy of Science, v. 50 , no. 2, p. 105-114.

1947b, Methods used in ground-water investigations in Kansas: Geological Society of America Bulletin, v. 58 , no. 12 , pt. 2 , p. 1273.

*Waite, H.A., 1947, Geology and ground-water resources of Scott County, Kansas: Kansas Geological Survey Bulletin 66, $216 \mathrm{p}$.

Williams, C.C., and Lohman, S.W., 1947, Methods used in estimating the ground water supply in the Wichita, Kansas well-field area: EOS, Transactions of the American Geophysical Union, v. 28, no. 1, p. 120-131.

\section{8}

*Byrne, F.E., and McLaughlin, T.G., 1948, Geology and ground-water resources of Seward County, Kansas: Kansas Geological Survey Bulletin 69, 140 p.

*Fishel, V.C., 1948a, Geology and ground-water resources of Republic County and northern Cloud County, Kansas: Kansas Geological Survey Bulletin 73, 194 p.

* _ 1948b, Ground-water resources of the Kansas City, Kansas, area: Kansas Geological Survey Bulletin 71, 109 p.

*Latta, B.F., 1948a, Geology and ground-water resources of Kiowa County, Kansas: Kansas Geological Survey Bulletin 65, $151 \mathrm{p}$.

*__ 1948b, Ground-water supplies at Hays, Victoria, Walker, Gorham, and Russell, Kansas, with special reference to future needs: Kansas Geological Survey Bulletin 76, pt. 6, p. 121-196.

Prescott, G.C., Jr., 1948, Preliminary report on the groundwater resources of Labette County, Kansas: Kansas Geological Survey Open-File Report 48-7, 15 p.

*Williams, C.C., 1948, Contamination of deep water wells in southeastern Kansas: Kansas Geological Survey Bulletin 76, pt. 2, p. 13-28.

1949

*Frye, J.C., and Fishel, V.C., 1949, Ground water in southwestern Kansas: Kansas Geological Survey Miscellaneous Publication, 24 p.

*Frye, J.C., and Leonard, A.R., 1949, Geology and ground-water resources of Norton County and northwestern Phillips County, Kansas: Kansas Geological Survey Bulletin 81, 144 p.

*Latta, B.F., 1949, Ground-water conditions in the Smoky Hill Valley in Saline, Dickinson, and Geary Counties, Kansas: Kansas Geological Survey Bulletin 84, 152 p.

*McLaughlin, T.G., 1949, Geology and ground-water resources of Pawnee and Edwards Counties, Kansas: Kansas Geological Survey Bulletin 80, 189 p.

O'Connor, H.G., 1949, Notes on the ground-water resources of Chase County, Kansas: Transactions of the Kansas Academy of Science, v. 52, no. 3, p. 399-405.

*Williams, C.C., and Lohman, S.W., 1949, Geology and ground-water resources of a part of south-central Kansas, with specific references to the Wichita municipal water supply: Kansas Geological Survey Bulletin 79, 455 p.

1950

*Fent, O.S., 1950, Geology and ground-water resources of Rice County, Kansas: Kansas Geological Survey Bulletin 85, 142 p.

*Frye, J.C., and Walters, K.L., 1950, Subsurface reconnaissance of glacial deposits in northeastern Kansas: Kansas Geological Survey Bulletin 86, pt. 6, p. 141-158.

*Latta, B.F., 1950, Geology and ground-water resources of Barton and Stafford Counties, Kansas: Kansas Geological Survey Bulletin 88, 228 p. 
Durum, W.H., 1951, Chemical quality of the surface waters in the Saline River Basin, Kansas, a progress report: U.S. Geological Survey Open-File Report, 54 p.

*O'Connor, H.G., 1951, Ground-water resources of Chase County [Kansas]: Kansas Geological Survey, v. 11, pt. 3, p. 28-49.

*Prescott, G.C., Jr., 1951, Geology and ground-water resources of Lane County, Kansas: Kansas Geological Survey Bulletin 93, 126 p.

\section{2}

Berry, D.W., 1952, Geology and ground-water resources of Lincoln County, Kansas, with a chapter on The chemical quality of ground water, by W.H. Durum: Kansas Geological Survey Bulletin 95, 96 p.

*Davis, S.N., and Carlson, W.A., 1952, Geology and ground-water resources of the Kansas River Valley between Lawrence and Topeka, Kansas: Kansas Geological Survey Bulletin 96, pt. 5, p. 201-276.

*Fishel, V.C., 1952, Ground-water resources of Pawnee Valley, Kansas: Kansas Geological Survey Bulletin 94, $144 \mathrm{p}$.

Leonard, A.R., 1952, Geology and ground-water resources of the North Fork Solomon River in Mitchell, Osborne, Smith, and Phillips Counties, Kansas: Kansas Geological Survey Bulletin 98, 150 p.

U.S. Geological Survey, 1952, Kansas-Missouri floods of July 1, 1951, with a section on Fluctuations of groundwater levels, by V.C. Fishel: U.S. Geological Survey Water-Supply Paper 1139, 239 p.

Waterman, W.D., 1952, Geology and hydrology of the Kanopolis Unit in Ellsworth, McPherson, and Saline Counties, Kansas, with a section on The chemical quality of the water, by R.A. Krieger: Kansas Geological Survey Open-File Report ND-27, 186 p.

1953

Durum, W.H., 1953, Relationship of the mineral constituents in solution to streamflow, Saline River near Russell, Kansas: EOS, Transactions of the American Geophysical Union, v. 34, no. 3, p. 435-442.

*Fishel, V.C., Searcy, J.K., and Rainwater, F.H., 1953, Water resources of the Kansas City area, Missouri and Kansas: U.S. Geological Survey Circular 273, 52 p.

Lohman, S.W., and Burtis, V.M., 1953, Areas of principal ground-water investigations in the Arkansas, White, and Red River Basins: U.S. Geological Survey
Hydrologic Investigations Atlas HA-2, 1 sheet, scale $1: 2,500,000$.

Lohman, S.W., Burtis, V.M., and others, 1953, General availability of ground water and depths to water level in the Arkansas, White, and Red River Basins: U.S. Geological Survey Hydrologic Investigations Atlas HA-3, 1 sheet, scale 1:2,500,000.

O'Connor, H.G., 1953, Ground-water resources of Lyon County [Kansas]: Kansas Geological Survey, v. 12, pt. 3, p. 35-59.

Prescott, G.C., Jr., 1953a, Geology and ground-water resources of Cheyenne County, Kansas: Kansas Geological Survey Bulletin 100, 106 p.

$1953 \mathrm{~b}$, Geology and ground-water resources of Sherman County, Kansas: Kansas Geological Survey Bulletin 105, $130 \mathrm{p}$.

Walters, K.L., 1953, Geology and ground-water resources of Jackson County, Kansas: Kansas Geological Survey Bulletin 101, 91 p.

\section{4}

Prescott, G.C., Jr., Branch, J.R., and Wilson, W.W., 1954, Geology and ground-water resources of Wichita and Greeley Counties, Kansas: Kansas Geological Survey Bulletin 108, $134 \mathrm{p}$.

Walters, K.L., 1954, Geology and ground-water resources of Marshall County, Kansas: Kansas Geological Survey Bulletin 106, $116 \mathrm{p}$.

\section{5}

Fishel, V.C., and Leonard, A.R., 1955, Geology and ground-water resources of Jewell County, Kansas: Kansas Geological Survey Bulletin 115, 152 p.

O'Connor, H.G., 1955, Ground-water resources of Osage County [Kansas]: Kansas Geological Survey, v. 13, pt. 3, p. 28-49.

Prescott, G.C., Jr., 1955, Geology and ground-water resources of Graham County, Kansas: Kansas Geological Survey Bulletin 110, 98 p.

U.S. Geological Survey, 1955, Availability, use, and control of water: Report of the Arkansas-White-Red Basins Inter-Agency Committee, pt. 2, sec. 17, 122 p.

\section{6}

Bayne, C.K., 1956a, Geology and ground-water resources of Reno County, Kansas: Kansas Geological Survey Bulletin 120,130 p. 
1956b, Geology and ground-water resources of Sheridan County, Kansas: Kansas Geological Survey Bulletin 116, 94 p.

Fishel, V.C., 1956, Long-term trends of ground-water levels in the United States: EOS, Transactions of the American Geophysical Union, v. 37, no. 4, p. 429-435.

Johnson, C.R., 1956, The ground-water resources of the Prairie Dog Valley area in Kansas: Kansas Geological Survey Open-File Report 56-4, $171 \mathrm{p}$.

Stramel, G.J., 1956, Progress report on the ground-water hydrology of the Equus-beds area, Kansas: Kansas Geological Survey Bulletin 119, pt. 1, 59 p.

Walters, K.L., 1956, Geology and ground-water resources of Rawlins County, Kansas: Kansas Geological Survey Bulletin 117, $100 \mathrm{p}$.

\section{7}

Bradley, Edward, and Johnson, C.R., 1957, Groundwater resources of the Ladder Creek area in Kansas, with a section on The chemical quality of water, by R.A. Krieger: Kansas Geological Survey Bulletin 126, $194 \mathrm{p}$.

*Fishel, V.C., and Mason, B.J., 1957, Ground-water levels in observation wells in Kansas, 1956: Kansas Geological Survey Bulletin 125, $158 \mathrm{p}$.

Furness, L.W., 1957, Development of a balanced streamgaging program for Kansas: Kansas Water Resources Board Bulletin No. 4, 50 p.

Leeson, E.R., 1957, History of natural flow, Kansas River: U.S. Geological Survey Open-File Report, 5 p.

Stramel, G.J., 1957, The hydraulic properties of the Ordovician rocks at Pittsburg, Kansas: Kansas Geological Survey Bulletin 127, pt. 5, p. 153-178.

\section{8}

Bayne, C.K., 1958, Ground-water resources of Elk County, Kansas: Kansas Geological Survey, v. 14, pt. 3, p. 37-56.

Dufford, A.E., 1958, Quaternary geology and ground-water resources of the Kansas River Valley between Bonner Springs and Lawrence, Kansas: Kansas Geological Survey Bulletin 130, pt. 1, 96 p.

*Fishel, V.C., and Mason, B.J., 1958, Ground-water levels in observation wells in Kansas, 1957: Kansas Geological Survey Bulletin 131, $152 \mathrm{p}$.

Johnson, C.R., 1958, Geology and ground-water resources of Logan County, Kansas: Kansas Geological Survey Bulletin 129, 175 p.
Kansas Water Board, 1958-62, State water plan studies, Part A-Preliminary appraisal of Kansas water problems:

Sec. 1, Marais des Cygnes Unit, June 1958, 189 p.

Sec. 2, Cimarron Unit, Sept. 1958, 124 p.

Sec. 3, Kansas Unit, June 1959, 193 p.

Sec. 4, Lower Arkansas Unit, Jan. 1960, 177 p.

Sec. 5, Walnut-Verdigris Unit, June 1960, 160 p.

Sec. 6, Upper Republican Unit, June 1960, 111 p.

Sec. 7, Neosho Unit, June 1961, 134 p.

Sec. 8, Solomon-Saline Unit, June 1961, 154 p.

Sec. 9, Lower Republican Unit, June 1961, 99 p.

Sec. 10, Missouri Unit, June 1962, 109 p.

Sec. 11, Upper Arkansas Unit, June 1962, 121 p.

Sec. 12, Smoky Hill Unit, June 1962, 125 p.

Mundorff, J.C., 1958, Sediment studies in Kansas, 1957-1958: Kansas Water News, v. 2, no. 1, p. 6-7.

Stramel, G.J., Lane, C.W., and Hodson, W.G., 1958, Geology and ground-water hydrology of the Ingalls area, Kansas: Kansas Geological Survey Bulletin 132, $154 \mathrm{p}$.

U.S. Geological Survey, 1958, Pumping tests at the Goodyear Tire and Rubber Company, Topeka, Kansas:

U.S. Geological Survey Open-File Report, 12 p.

\section{9}

Bayne, C.K., and Walters, K.L., 1959, Geology and ground-water resources of Cloud County, Kansas: Kansas Geological Survey Bulletin 139, 144 p.

*Fishel, V.C., Gulley, E.L., and Reavis, E.L., 1959, Ground-water levels in observation wells in Kansas, 1958: Kansas Geological Survey Bulletin 141, 146 p.

Furness, L.W., 1959, Kansas streamflow characteristics, part 1, Flow duration: Kansas Water Resources Board Technical Report No. 1, 213 p.

Hodson, W.G., 1959, Geology and ground-water resources of Mitchell County, Kansas: Kansas Geological Survey Bulletin 140, $132 \mathrm{p}$.

U.S. Geological Survey, 1959, Floods of the Kansas River, Topeka, Kansas in 1935 and 1951: U.S. Geological Survey Hydrologic Investigations Atlas HA-14, 1 sheet, scale 1:24,000.

Walters, K.L., and Bayne, C.K., 1959, Geology and ground-water resources of Clay County, Kansas: Kansas Geological Survey Bulletin 136, 106 p. 
Bayne, C.K., 1960, Geology and ground-water resources of Harper County, Kansas: Kansas Geological Survey Bulletin 143, 183 p.

Ellis, D.W., and Edelen, G.W., Jr., 1960, Kansas streamflow characteristics, part 3, Flood frequency: Kansas Water Resources Board Technical Report No. 3, 221 p.

*Fishel, V.C., and Broeker, M.E., 1960, Ground-water levels in observation wells in Kansas, 1959: Kansas Geological Survey Bulletin 146, 174 p.

Furness, L.W., 1960, Kansas streamflow characteristics, part 2, Low-flow frequency: Kansas Water Resources Board Technical Report No. 2, 179 p.

Hodson, W.G., and Wahl, K.D., 1960, Geology and ground-water resources of Gove County, Kansas: Kansas Geological Survey Bulletin 145, 126 p.

Landis, E.R., 1960, Uranium content of ground and surface waters in a part of the central Great Plains: U.S. Geological Survey Bulletin 1087-G, p. 223-258.

Lane, C.W., 1960, Geology and ground-water resources of Kingman County, Kansas: Kansas Geological Survey Bulletin 144, $174 \mathrm{p}$.

*O'Connor, H.G., 1960, Geology and ground-water resources of Douglas County, Kansas: Kansas Geological Survey Bulletin 148, 200 p.

\section{1}

*Broeker, M.E., and Fishel, V.C., 1961, Ground-water levels in observation wells in Kansas, 1960: Kansas Geological Survey Bulletin 153, 183 p.

Leonard, A.R., and Berry, D.W., 1961, Geology and ground-water resources of southern Ellis County and parts of Trego and Rush Counties, Kansas: Kansas Geological Survey Bulletin 149, 156 p.

Mundorff, J.C., 1961, A program of fluvial sediment investigations in Kansas: Kansas Water Resources Board Bulletin No. 6, 48 p.

Schumm, S.A., and Lichty, R.W., 1961, Recent flood-plain formation along the Cimarron River in Kansas: U.S. Geological Survey Professional Paper 424-B, p. B112.

Walters, K.L., 1961, Geology and ground-water resources of Sumner County, Kansas: Kansas Geological Survey Bulletin 151, $198 \mathrm{p}$.

Ward, P.E., and Leonard, A.R., 1961, Hypothetical circulation of ground water around salt springs in western Oklahoma, Texas, and Kansas: U.S. Geological Survey Professional Paper 424-D, p. D150.
Albert, C.D., 1962, Sediment investigations in Kansas: Kansas Water News, v. 5, no. 4, p. 5-7.

Bayne, C.K., 1962, Geology and ground-water resources of Cowley County, Kansas: Kansas Geological Survey Bulletin 158, $219 \mathrm{p}$.

Bedinger, M.S., and Tanaka, H.H., 1962, Effect of the Kirwin reservoir, Kansas, on ground-water levels: U.S. Geological Survey Open-File Report, 11 p.

*Broeker, M.E., and Fishel, V.C., 1962, Ground-water levels in observation wells in Kansas, 1961: Kansas Geological Survey Bulletin 159, 165 p.

Diaz, A.M., 1962a, Chemical quality program in Kansas: Kansas Water News, v. 5, no. 3, p. 3-5.

1962b, Quality of water investigation in the Walnut River Basin: Kansas Water News, v. 5, no. 3, p. 6-7.

Furness, L.W., 1962, Kansas streamflow characteristics, part 4, Storage requirements to sustain gross reservoir outflow: Kansas Water Resources Board Technical Report No. 4, 177 p.

Lane, C.W., Reavis, E.L., and Stramel, G.J., 1962, Emergency water supplies in the Wichita area, Kansas: U.S. Geological Survey Hydrologic Investigations Atlas HA-58, 36 p., 1 sheet, scale 1:250,000.

Mack, L.E., 1962, Geology and ground-water resources of Ottawa County, Kansas: Kansas Geological Survey Bulletin 154, $145 \mathrm{p}$.

Meyers, J.S., 1962, Evaporation from the 17 western states, with a section on Evaporation rates, by T.J. Nordenson: U.S. Geological Survey Professional Paper 272-D, p. $71-100$.

*Thomas, H.E., 1962, The meteorological phenomenon of drought in the Southwest: U.S. Geological Survey Professional Paper 372-A, p. A1-A43.

U.S. Geological Survey, 1962, Surface water records of Kansas, 1961: U.S. Geological Survey Water-Data Report, $165 \mathrm{p}$.

1963

*Broeker, M.E., and Winslow, J.D., 1963, Ground-water levels in observation wells in Kansas, 1962: Kansas Geological Survey Bulletin 167, 89 p.

${ }^{*}$ Busby, M.W., 1963, Yearly variations in runoff for the conterminous United States, 1931-60: U.S. Geological Survey Water-Supply Paper 1669-S, p. S1-S49.

Culbertson, D.M., 1963, Coordinated water-quality investigations in Kansas: 130th Meeting, Missouri Basin Inter-Agency Commission, 12 p. 
Ellis, D.W., and others, 1963, Floods at Wichita, Kansas: U.S. Geological Survey Hydrologic Investigations Atlas HA-63, 5 sheets, scale 1:24,000.

*Fishel, V.C., 1963, Kansas, in McGuinness, C.L., The role of ground water in the national water situation: U.S. Geological Survey Water-Supply Paper 1800, 1121 p.

Hodson, W.G., 1963, Geology and ground-water resources of Wallace County, Kansas: Kansas Geological Survey Bulletin 161, 108 p.

*Meyer, W.R., 1963, Use of a neutron moisture probe to determine the storage coefficient of an unconfined aquifer: U.S. Geological Survey Professional Paper 450-E, p. E174-E176.

Schumm, S.A., and Lichty, R.W., 1963, Channel widening and flood-plain construction along the Cimarron River in southwestern Kansas: U.S. Geological Survey Professional Paper 352-D, p. 71-88.

U.S. Geological Survey, 1963, Surface water records of Kansas, 1962: U.S. Geological Survey Water-Data Report, 179 p.

\section{4}

Albert, C.D., 1964, Brine in surface water of the Little Arkansas River Basin, Kansas: Kansas Department of Health and Environment Bulletin No. 1-5, 15 p.

*Broeker, M.E., and Winslow, J.D., 1964, Ground-water levels in observation wells in Kansas, 1963: Kansas Geological Survey Bulletin 173, 93 p.

*Busby, M.W., 1964, Relation of annual runoff to meteorological factors, in Geological Survey Research, 1964, Chapter C: U.S. Geological Survey Professional Paper 501-C, p. C188-C189.

Fader, S.W., Gutentag, E.D., Lobmeyer, D.H., and Meyer, W.R., 1964, Geohydrology of Grant and Stanton Counties, Kansas: Kansas Geological Survey Bulletin 168, $147 \mathrm{p}$.

Furness, L.W., Burns, C.V., and Busby, M.W., 1964, Kansas streamflow characteristics, part 5, Storage requirements to control high flow: Kansas Water Resources Board Technical Report No. 5, 169 p.

*Jordan, P.R., Jones, B.F., and Petri, L.R., 1964, Chemical quality of surface waters and sedimentation in the Saline River Basin, Kansas: U.S. Geological Survey Water-Supply Paper 1651, $90 \mathrm{p}$.

*Leonard, R.B., 1964a, A method for evaluating oil-fieldbrine pollution of the Walnut River in Kansas, in Geological Survey Research, 1964, Chapter B: U.S. Geological Survey Professional Paper 501-B, p. B173-B176. 1964b, Cooperative water-quality investigations of the Walnut River Basin, Kansas: Kansas Water News, v. 7, no. 5, p. 5-6.

$1964 c$, Results of four chemical-quality surveys of the Walnut River Basin, Kansas (December 1961 to October 1963): Kansas Department of Health and Environment Bulletin No. 1-3, 38 p.

Leonard, R.B., and Shah, K.L., 1964, The relation of the chemical quality of the Whitewater River at Towanda to that of the Walnut River at Winfield, Kansas during the 1963 water year: Kansas Department of Health and Environment Bulletin No. 1-2, 18 p.

Mayes, J.L., and Culbertson, Don, 1964, Chemical quality of surface waters in Kansas, 1962 water year: Kansas Department of Health and Environment Bulletin No. 1-4, 61 p.

Mundorff, J.C., and Scott, C.H., 1964, Fluvial sediment in the lower Kansas River Basin-A progress report 1957-60: Kansas Water Resources Board Bulletin No. 7, $67 \mathrm{p}$.

*Petri, L.R., Lane, C.W., and Furness, L.W., 1964, Water resources of the Wichita area, Kansas: U.S. Geological Survey Water-Supply Paper 1499-I, 69 p.

U.S. Geological Survey, 1964a, Status of water-resources investigations in Kansas: U.S. Geological Survey folder.

1964b, Surface water records of Kansas, 1963: U.S. Geological Survey Water-Data Report, 191 p.

Winslow, J.D., Nuzman, C.E., and Fader, S.W., 1964, Water-level changes in Grant and Stanton Counties, 1939-1964: Kansas Geological Survey Special Distribution Publication 10, 11 p.

\section{5}

Broeker, M.E., and Winslow, J.D., 1965, Ground-water levels in observation wells in Kansas, 1964: Kansas Geological Survey Bulletin 177, 93 p.

Busby, M.W., and Armentrout, G.W., 1965, Kansas streamflow characteristics, part 6A, Base-flow data: Kansas Water Resources Board Technical Report No. 6A, 207 p.

Collins, D.L., 1965, A general classification of source areas of fluvial sediment in Kansas: Kansas Water Resources Board Bulletin No. 8, 21 p.

Diaz, A.M., 1965, Cooperative water-quality investigation, South Fork Ninnescah Basin: Kansas Water News, v. 8 , no. 3 , p. $3-4$

Furness, L.W., 1965a, Discussion of areal variations of mean annual runoff: American Society Civil Engineers Proceedings 4304, May, p. 336-341. 
1965b, Small area flood volume study, Rock Creek Basin, Meriden, Kans.-..-Progress report, July 1963 to Feb. 1965: U.S. Geological Survey Open-File Report, $42 \mathrm{p}$.

Hodson, W.G., 1965, Geology and ground-water resources of Trego County, Kansas: Kansas Geological Survey Bulletin 174, 80 p.

Lane, C.W., and Miller, D.E., 1965a, Geohydrology of Sedgwick County, Kansas: Kansas Geological Survey Bulletin 176, $100 \mathrm{p}$.

1965b, Logs of wells and test holes in Sedgwick County, Kansas: Kansas Geological Survey Special Distribution Publication 22, 175 p.

Mayes, J.L., and Diaz, A.M., 1965, Chemical quality of surface waters in Kansas, 1963 water year: Kansas Department of Health and Environment Bulletin No. 1-8, 67 p.

Mayes, J.L., Stoltenberg, G.A., and Burris, N.J., 1965, Chemical quality of public water supplies in Kansas: Kansas Department of Health and Environment Bulletin No. 1-7, 39 p.

Nuzman, C.E., and Meyer, W.R., 1965, Water-level change in Grant and Stanton Counties, Kansas, 1939-1965: Kansas Geological Survey Special Distribution Publication 18, $11 \mathrm{p}$.

U.S. Geological Survey, 1965, Surface water records of Kansas, 1964: U.S. Geological Survey Water-Data Report, 215 p.

\section{6}

*Albert, C.D., and Stramel, G.J., 1966, Fluvial sediment in the Little Arkansas River Basin, Kansas: U.S. Geological Survey Water-Supply Paper 1798-B, p. B1-B30.

Angino, E.E., and Morgan, C.O., 1966, Application of pattern analysis to the classification of oil-field brines, in Merriam, D.F., ed., Computer applications in the earth sciences-Colloquium on classification procedures: Kansas Geological Survey Computer Contributions Series 7, p. 53-56.

Broeker, M.E., and Winslow, J.D., 1966, Ground-water levels in observation wells in Kansas, 1965: Kansas Geological Survey Bulletin 184, 91 p.

Busby, M.W., 1966, Annual runoff in the conterminous United States: U.S. Geological Survey Hydrologic Investigations Atlas HA-212, 1 sheet, scale 1:7,500,000.

Furness, L.W., Burns, C.V., and Busby, M.W., 1966, Kansas streamflow characteristics, part 6B, Base flow distribution: Kansas Water Resources Board Technical Report No. 6B, 139 p.
Irza, T.J., 1966, Preliminary flood-frequency relations for small streams in Kansas: U.S. Geological Survey Open-File Report, $19 \mathrm{p}$.

Jungmann, W.L., 1966, Geology and ground-water resources of Neosho County, Kansas: Kansas Geological Survey Bulletin 183, $46 \mathrm{p}$.

La Rocque, G.A., Jr., 1966, General availability of ground water and depth to water level in the Missouri River Basin: U.S. Geological Survey Hydrologic Investigations Atlas HA-217, 1 sheet, scale 1:2,500,000.

Miller, D.E., 1966, Geology and ground-water resources of Miami County, Kansas: Kansas Geological Survey Bulletin 181, $66 \mathrm{p}$.

Morgan, C.O., Dingman, R.J., and McNellis, J.M., 1966, Digital computer methods for water-quality data: Ground Water, Technical Division Journal, National Water Well Association, v. 4, no. 3, July, p. 35-42.

*Mundorff, J.C., and Waddell, K.M., 1966, Fluvial sediment and chemical quality of water in the Little Blue River Basin, Nebraska and Kansas: U.S. Geological Survey Water-Supply Paper 1819-H, p. $\mathrm{H} 1-\mathrm{H} 45$.

Roberts, R.S., and Hodson, W.G., 1966, Ground water in Kansas-Bibliography and subject index: Kansas Geological Survey Bulletin 182, 41 p.

Stramel, G.J., 1966, Progress report on the ground-water hydrology of the Equus-beds area, Kansas-1966: Kansas Geological Survey Bulletin 187, pt. 2, 27 p.

U.S. Geological Survey, 1966a, Ground water in the Cimarron River Basin, New Mexico, Colorado, Kansas, and Oklahoma: U.S. Geological Survey Open-File Report, 51 p.

1966b, Water quality records in Kansas, 1964: U.S. Geological Survey Water-Data Report, 205 p.

1966c, Water resources data for Kansas-Part 1, Surface water records, 1965: U.S. Geological Survey Water-Data Report, 202 p.

1966d, Water-resources investigations in Kansas, 1965: U.S. Geological Survey folder.

Winslow, J.D., and Nuzman, C.E., 1966, Electronic simulation of ground-water hydrology in the Kansas River Valley near Topeka, Kansas: Kansas Geological Survey Special Distribution Publication 29, 24 p.

\section{7}

Bayne, C.K., and Schoewe, W.H., 1967, Geology and ground-water resources of Brown County, Kansas: Kansas Geological Survey Bulletin 186, 68 p.

*Bayne, C.K., and Ward, J.R., compilers, 1967, General availability of ground water in Kansas: Kansas Geological Survey Map M-4, 1 sheet, scale 1:500,000. 
Burns, C.V., 1967, Kansas streamflow characteristics, part 7, Annual streamflow summary tables: Kansas Water Resources Board Technical Report No. 7, 18 p.

Fader, S.W., 1967, Notes on the shape of the truncated cone of depression in the vicinity of an infinite well field: Kansas Geological Survey Special Distribution Publication 33, 10 p.

*Furness, L.W., and Busby, M.W., 1967, Two methods of estimating base flow at ungaged stream sites in Kansas and adjacent states, in Geological Survey Research, 1967, Chapter C: U.S. Geological Survey Professional Paper 575-C, p. C208-C211.

James, I.C., II, 1967, Flood runoff from partially urbanized areas, Wichita, Kansas-Report No. 1, Analysis of initial conditions: U.S. Geological Survey Open-File Report, 62 p.

*Johnson, W.D., Jr., Adkison, W.L., and Wagner, H.C., 1967, Geology of Shawnee County, Kansas: U.S. Geological Survey Bulletin 1215, 254 p.

U.S. Geological Survey, 1967a, Water resources data for Kansas-Part 1, Surface water records, 1966: U.S. Geological Survey Water-Data Report, 202 p.

1967b, Water resources data for Kansas - Part 2, Water quality records, 1965: U.S. Geological Survey Water-Data Report, 223 p.

\section{8}

Fader, S.W., 1968, Ground water in the Republican River area, Cloud, Jewell, and Republic Counties, Kansas: Kansas Geological Survey Bulletin 188, 27 p.

James, I.C., II, 1968, Streamflow generalization in an area of the central United States: U.S. Geological Survey Open-File Report, 60 p.

Jungmann, W.L., and Williams, C.C., 1968, Geology and ground water in Labette County, Kansas: U.S. Geological Survey Hydrologic Investigations Atlas HA-279, 1 sheet, scale 1:63,390.

McNellis, J.M., Morgan, C.O., and Lowell, B.H., 1968, Digital computer applications that facilitate collection and interpretation of ground-water data, in International Association Scientific Hydrology, The use of analog and digital computers in hydrology-A symposium: International Association Scientific Hydrology Publication No. 81 A1HS, v. 2, p. 561-568.

Prill, R.C., 1968, Movement of moisture in the unsaturated zone in a dune area, southwestern Kansas, in Geological Survey Research, 1968, Chapter B: U.S. Geological Survey Professional Paper 600-B, p. B1-B9.

*Prill, R.C., and Meyer, W.R., 1968, Neutron moisture measurements by continuous- and point-logging procedures, in Geological Survey Research, 1968,
Chapter D: U.S. Geological Survey Professional Paper 600-D, p. D1-D9.

U.S. Geological Survey, 1968a, Water resources data for Kansas_Part 1, Surface water records, 1967: U.S. Geological Survey Water-Data Report, 204 p.

$\mathbf{1 9 6 8 b}$, Water resources data for Kansas-Part 2, Water quality records, 1966: U.S. Geological Survey Water-Data Report, 223 p.

Winslow, J.D., McGovern, H.E., and Mackey, H.L., 1968, Water-level changes in Grant and Stanton Counties, Kansas, 1939-1968: Kansas Geological Survey Special Distribution Publication 37, 17 p.

\section{9}

Albert, C.D., 1969, Total sediment discharge of selected streams in Kansas, 1957-65, a compilation: Kansas Water Resources Board Bulletin No. 10, 8 p.

Bayne, C.K., and Ward, J.R., 1969, Saturated thickness and specific yield of Cenozoic deposits in Kansas: Kansas Geological Survey Map M-5, 1 sheet, scale 1:500,000.

Dingman, R.J., 1969, Evaluation of the effects of the U.S. Bureau of Reclamation ring dike on the ground-water flow and water quality in the Downs area, Kansas: U.S. Geological Survey Open-File Report, 19 p.

Dingman, R.J., and Angino, E.E., 1969, Chemical composition of selected Kansas brines as an aid to interpreting change in water chemistry with depth: Chemical Geology, Amsterdam, v. 4, p. 325-339.

Gillespie, J.B., Lindskov, K.L., and Slagle, S.E., 1969, Artificial ground-water recharge, Wet Walnut Creek-Progress report number one: Kansas Water Resources Board, 22 p.

Gutentag, E.D., and Galli-Olivier, Carlos, 1969, New locations of Pleistocene (Kansan) molluscan and ostracode faunas, Dickinson County, Kansas, in Geological Survey Research: U.S. Geological Survey Professional Paper 650-D, p. D148-D154.

Hodson, W.G., 1969, Geology and ground-water resources of Decatur County, Kansas: Kansas Geological Survey Bulletin 196, 41 p.

*Keene, K.M., Pearl, R.H., and Pabst, M.E., 1969, Hydrogeologic data from Cheyenne, Decatur, Rawlins, Sheridan, Sherman, and Thomas Counties, Kansas: Kansas Geological Survey Basic-Data Series, GroundWater Release 1, 113 p.

Leonard, R.B., 1969a, Effect of irrigation on the chemical quality of low streamflow adjacent to Cedar Bluff Irrigation District, Kansas, a progress report: Kansas Department of Health and Environment Bulletin No. 1-10, 17 p. 
$1969 \mathrm{~b}$, Time of travel study on the Big Blue River: Kansas Water News, v. 12, no. 3, p. 7 and 8 .

MeNellis, J.M., and Morgan, C.O., 1969, Modified Piper diagrams by the digital computer: Kansas Geological Survey Distribution Publication 45, 36 p.

McNellis, J.M., Morgan, C.O., and Lowell, B.H., 1969, Computer-produced tables, maps, and diagrams as tools in the interpretation of brine data from southeastern Kansas (U.S.A.): Chemical Geology, Amsterdam, v. 4, p. 303-324.

Meyer, W.R., Gutentag, E.D., and Lobmeyer, D.H., 1969, Finney County basic data: U.S. Geological Survey Open-File Report, 146 p.

Miller, D.E., 1969, Geology and ground-water resources of Allen County, Kansas: Kansas Geological Survey Bulletin 195, $50 \mathrm{p}$.

Morgan, C.O., and McNellis, J.M., 1969a, FORTRAN IV programs, KANS, for the conversion of General Land Office locations to latitude and longitude coordinates:

Kansas Geological Survey Special Distribution Publication 42, 24 p.

$1969 \mathrm{~b}$, Stiff diagrams of water-quality data programmed for the digital computer: Kansas Geological Survey Special Distribution Publication 43, $26 \mathrm{p}$.

Morgan, C.O., McNellis, J.M., and Lowell, B.H., 1969 , Computer applications in hydrology in Kansas, in Zeller, D.E., ed., Short papers on research in 1968: Kansas Geological Survey Bulletin 194, pt. 1, p. 3-7.

*Ropes, L.H., Morgan, C.O., and McNellis, J.M., 1969, FORTRAN IV program for synthesis and plotting of water-quality data: Kansas Geological Survey Special Distribution Publication 39, 59 p.

Seevers, W.J., 1969, Geology and ground-water resources of Linn County, Kansas: Kansas Geological Survey Bulletin 193, 65 p.

U.S. Geological Survey, 1969a, Water resources data for Kansas-Part 1, Surface water records, 1968: U.S. Geological Survey Water-Data Report, 212 p.

$1969 b$, Water resources investigations in Kansas, 1968: U.S. Geological Survey folder.

\section{0}

Dabiri, H.E., Green, D.W., and Winslow, J.D., 1970, Digital computer simulation of an aquifer, in Proceedings of Summer Computer Simulation Conference, Denver, Colo., June 10-12, 1970, p. 944-954.

Gillespie, J.B., Green, D.W., and Slagle, S.E., 1970, Artificial ground-water recharge, Wet Walnut Creek, central Kansas-Progress report number two: Kansas Water Resources Board, 28 p.
Gutentag, E.D., Lobmeyer, D.H., and McGovern, H.E., 1970, Ground water in Kearny County, southwestern Kansas: U.S. Geological Survey Open-File Report, $40 \mathrm{p}$.

Jordan, P.R., and Hedman, E.R., 1970, Evaluation of the surface-water data program in Kansas: Kansas Water Resources Board Bulletin No. 12, 49 p.

Leonard, R.B., 1970, Variations in the chemical quality of ground water beneath an irrigated field, Cedar Bluff Irrigation District, Kansas: Kansas Department of Health and Environment Bulletin No. 1-11, 20 p.

Leonard, R.B., and Morgan, C.O., 1970, Application of computer techniques to seepage-salinity surveys in Kansas: Kansas Geological Survey Special Distribution Publication 47, $44 \mathrm{p}$.

*Lowell, B.H., Morgan, C.O., and McNellis, J.M., 1970, Brief descriptions of and examples of output from computer programs developed for use with water data in Kansas: Kansas Geological Survey Special Distribution Publication 48, 54 p.

Meyer, W.R., Gutentag, E.D., and Lobmeyer, D.H., 1970, Geohydrology of Finney County, southwestern Kansas: U.S. Geological Survey Water-Supply Paper 1891, $117 \mathrm{p}$.

U.S. Geological Survey, 1970a, Water resources data for Kansas-Part 1, Surface water records, 1969: U.S. Geological Survey Water-Data Report, 216 p.

$1970 b$, Water resources data for Kansas-Part 2, Water quality records, 1967: U.S. Geological Survey Water-Data Report, $191 \mathrm{p}$.

1970c, Water resources data for Kansas-Part 2, Water quality records, 1968: U.S. GeologicaI Survey Water-Data Report, 225 p.

\section{1}

Bayne, C.K., 1971, Geohydrology of Doniphan County, northeastern Kansas: U.S. Geological Survey OpenFile Report, 21 p.

Bayne, C.K., Franks, P.C., and Ives, William, Jr., 1971 Geology and ground-water resources of Ellsworth County, central Kansas: Kansas Geological Survey Bulletin 201, 84 p.

Burns, C.V., 1971, Kansas streamflow characteristics, part 8, In-channel hydraulic geometry of streams in Kansas: Kansas Water Resources Board Technical Report No. 8, 31 p.

*Keene, K.M., and Pabst, M.E., 1971, Hydrogeologic data from Gove, Logan, and Wallace Counties, Kansas: Kansas Geological Survey Basic-Data Series, Ground Water Release 2, 76 p. 
McClain, T.J., and Jenkins, E.D., 1971, Digital simulation of the Ogallala aquifer in Sherman County, northwestern Kansas, in Ogallala Aquifer Symposium: Texas Tech University Special Report 39, p. 72-88.

McGovern, H.E., 1971, Geology and ground water in the Ogallala Formation and undifferentiated Pleistocene deposits, southwestern Kansas, in Ogallala Aquifer Symposium: Texas Tech University Special Report 39, p. 15-29.

Morgan, C.O., and McNellis, J.M., 1971, Reduction of lithologic-log data to numbers for use in the digital computer: Mathematical Geology, v. 3, no. 1, p. 79-86.

O'Connor, H.G., 1971, Geology and ground-water resources of Johnson County, northeastern Kansas: Kansas Geological Survey Bulletin 203, 68 p.

U.S. Geological Survey, 1971a, Water resources data for Kansas-Part 1, Surface water records, 1970: U.S. Geological Survey Water-Data Report, 216 p.

1971b, Water resources data for Kansas-Part 2, Water quality records, 1969: U.S. Geological Survey Water-Data Report, 201 p.

1971c, Water resources data for Kansas--Part 2, Water quality records, 1970: U.S. Geological Survey Water-Data Report, 159 p.

Ward, J.R., 1971, Geohydrology of Atchison County, northeastern Kansas: U.S. Geological Survey OpenFile Report, 22 p.

Gillespie, J.B., and Slagle, S.E., 1972, Natural and artificial ground-water recharge, Wet Walnut Creek, central Kansas: Kansas Water Resources Board Bulletin 17, $94 \mathrm{p}$.

Gutentag, E.D., Lobmeyer, D.H., and McGovern, H.E., 1972, Ground water in Kearny County, southwestern Kansas: U.S. Geological Survey Hydrologic Investigations Atlas HA-416, 2 sheets, scale 1:125,000.

Gutentag, E.D., Lobmeyer, D.H., McGovern, H.E., and Long, W.A., 1972, Ground water in Finney County, southwestern Kansas: U.S. Geological Survey Hydrologic Investigations Atlas HA-442, 3 sheets, scale $1: 250,000$.

Halepaska, J.C., and Hartman, J.W., 1972, NumericaI solution of the three-dimensional heat flow equation: Kansas Geological Survey Bulletin 204, pt. 1, p. 11-13.

Hedman, E.R., and Kastner, W.M., 1972, Kansas streamflow characteristics, part 9, Mean annual runoff as related to channel geometry of selected streams in
Kansas: Kansas Water Resources Board Technical Report No. 9, 25 p.

Leonard, R.B., 1972, Chemical quality of water in the Walnut River Basin, south-central Kansas: U.S. Geological Survey Water-Supply Paper 1982, $113 \mathrm{p}$.

Leonard, R.B., and Stoltenberg, G.A., 1972, Compilation of data for water-quality investigation, Cedar Bluff Irrigation District, Kansas: Kansas Department of Health and Environment Bulletin No. 1-12, 158 p.

Pearl, R.H., Roberts, R.S., Keene, K.M., and McClain, T.J., 1972, Water resources of northwestern Kansas: U.S. Geological Survey Hydrologic Investigations Atlas HA-429, 2 sheets, scale 1:250,000.

Richards, D.B., and Dunaway, T.W., 1972, Geohydrologic data for numerical modeling of ground-water withdrawals in the Little Arkansas River Basin area, southcentral Kansas: U.S. Geological Survey Open-File Report, $426 \mathrm{p}$.

U.S. Geological Survey, 1972a, Water resources data for Kansas-Part 1, Surface water records, 1971: U.S. Geological Survey Water-Data Report, 206 p.

1972b, Water resources data for Kansas--Part 2, Water quality records, 1971: U.S. Geological Survey Water-Data Report, 140 p.

1972c, Water resources investigations in Kansas, 1972: U.S. Geological Survey folder.

Winslow, J.D., 1972, Geohydrology of Jefferson County, northeastern Kansas: Kansas Geological Survey Bulletin 202, pt. 4, 20 p.

\section{3}

Albert, C.D., 1973, Fluvial sediment characteristics of the Kansas River at Wamego, Kansas, 1957-70: U.S. Geological Survey Open-File Report, 13 p.

Bayne, C.K., 1973, Geohydrology of Doniphan County, northeastern Kansas: U.S. Geological Survey Hydrologic Investigations Atlas HA-462, 1 sheet, scale 1:62,500.

Broeker, M.E., and McNellis, J.M., 1973, Ground-water levels in observation wells in Kansas, 1966-70: Kansas Geological Survey Basic-Data Series, GroundWater Release 3, 373 p.

Layton, D.W., and Berry, D.W., 1973, Geology and ground-water resources of Pratt County, south-central Kansas: Kansas Geological Survey Bulletin 205, 33 p.

McNellis, J.M., 1973, Geology and ground-water resources of Rush County, central Kansas: Kansas Geological Survey Bulletin 207, 45 p.

O'Connor, H.G., 1973, Geohydrology for urban planning in Johnson County, northeastern Kansas: Kansas Geological Survey Open-File Report 73-9, 41 p. 
*Pabst, M.E., and Jenkins, E.D., 1973, Water-level changes in northwestern Kansas, 1950-73: Kansas Geological Survey Journal, October 1973, 14 p.

U.S. Geological Survey, 1973a, Water resources data for Kansas-Part 1, Surface water records, 1972: U.S. Geological Survey Water-Data Report, 202 p.

1973b, Water resources data for Kansas-Part 2, Water quality records, 1972: U.S. Geological Survey Water-Data Report, $154 \mathrm{p}$.

Ward, J.R., 1973, Geohydrology of Atchison County, northeastern Kansas: U.S. Geological Survey Hydrologic Investigations Atlas HA-467, 2 sheets, scale $1: 62,500$.

\section{4}

Bayne, C.K., and Ward, J.R., 1974, Geology and hydrology of Rice County, central Kansas: Kansas Geological Survey Bulletin 206, pt. 3, 17 p.

Fader, S.W., 1974, Ground water in the Kansas River Valley, Junction City to Kansas City, Kansas: Kansas Geological Survey Bulletin 206, pt. 2, 12 p.

Gutentag, E.D., and Stullken, L.E., 1974, Ground water in Haskell County, southwestern Kansas: U.S. Geological Survey Hydrologic Investigations Atlas HA-515, 2 sheets, scale 1:250,000.

Hedman, E.R., and Kastner, W.M., 1974, Progress report on streamflow characteristics as related to channel geometry of streams in the Missouri River Basin: U.S. Geological Survey Open-File Report, 24 p.

Hedman, E.R., Kastner, W.M., and Hejl, H.R., 1974, Kansas streamflow characteristics, part 10, Selected streamflow characteristics as related to active-channel geometry of streams in Kansas: Kansas Water Resources Board Technical Report No. 10, 21 p.

Kastner, W.M., 1974, Application of statistical techniques to the estimation of ground-water withdrawals in northwestern Kansas: U.S. Geological Survey WaterResources Investigations Report 41-74, $11 \mathrm{p}$.

Leonard, R.B., 1974, Changes in chemical quality of water, Cedar Bluff Irrigation District area, west-central Kansas: Kansas Geological Survey Chemical Quality Series $1,72 \mathrm{p}$.

Lobmeyer, D.H., and Sauer, C.G., 1974, Water resources of Hamilton County, southwestern Kansas: U.S. Geological Survey Hydrologic Investigations Atlas HA-516, 2 sheets, scales $1: 250,000$ and $1: 500,000$.

McGovern, H.E., and Long, W.A., 1974, Ground water in Gray County, southwestern Kansas: U.S. Geological Survey Hydrologic Investigations Atlas HA-517, 2 sheets, scale 1:250,000.
O'Connor, H.G., 1974, Geology and ground-water resources of Montgomery County southeastern Kansas: Kansas Geological Survey Ground-Water Series $1,12 \mathrm{p}$.

*Pabst, M.E., and Jenkins, E.D., 1974, Water-level changes in west-central Kansas, 1950-74: Kansas Geological Survey Journal, October 1974, 15 p.

Snipes, R.J., and others, 1974, Floods of June 1965 in Arkansas River Basin, Colorado, Kansas, and New Mexico: U.S. Geological Survey Water-Supply Paper 1850-D, p. D1-D97.

Stullken, L.E., Weakly, E.C., Gutentag, E.D., and Slagle, S.E., 1974, Hydrogeologic data from Greeley, Wichita, Scott, and Lane Counties, Kansas: Kansas Geological Survey Basic-Data Series, Ground-Water Release 4, $58 \mathrm{p}$.

U.S. Geological Survey, 1974a, Water resources data for Kansas-Part 1, Surface water records, 1973: U.S. Geological Survey Water-Data Report, 202 p.

1974b, Water resources data for Kansas-Part 2, Water quality records, 1973: U.S. Geological Survey Water-Data Report, 168 p.

Ward, J.R., 1974, Geohydrology of Nemaha County, northeastern Kansas: Kansas Geological Survey Ground-Water Series 2, $19 \mathrm{p}$.

\section{5}

Albin, D.R., 1975, Water resources alternative study areas, proposed Prairie National Park, Kansas-Oklahoma, in Preliminary environmental assessment, alternative study areas, proposed Prairie National Park, KansasOklahoma (appendix D): U.S. Department of Interior, National Park Service, $32 \mathrm{p}$.

Burns, C.V., 1975, Kansas streamflow characteristics, temperatures of Kansas streams: Kansas Water Resources Board Technical Report No. 12, 220 p.

Fader, S.W., 1975, Land subsidence caused by dissolution of salt near four oil and gas wells in central Kansas: U.S. Geological Survey Water-Resources Investigations Report 27-75, 28 p.

Fader, S.W., and Morton, R.B., 1975a, Ground water in the Middle Arkansas River Basin, Kansas and Oklahoma: U.S. Geological Survey Open-File Report 75-367, 44 p.

1975b, Ground water in the Verdigris River Basin, Kansas and Oklahoma: U.S. Geological Survey OpenFile Report 75-365, 26 p.

Gillespie, J.B., and Hargadine, G.D., 1975, Results of infiltration tests near Scott City, western Kansas: U.S. Geological Survey Water-Resources Investigations Report 76-12, $29 \mathrm{p}$. 
Gutentag, E.D., 1975, Map showing percent change in saturated thickness of unconsolidated aquifer, 1950-76, west-central Kansas: U.S. Geological Survey Open-File Report 76-457, 1 sheet, scale 1:125,000.

Hathaway, L.R., Magnuson, L.M., Carr, B.L., Galle, O.K., and Waugh, T.C., 1975, Chemical quality of irrigation waters in west-central Kansas: Kansas Geological Survey Chemical Quality Series 2, 46 p.

Jenkins, E.D., and Pabst, M.E., 1975, Water development for irrigation in northwestern Kansas: U.S. Geological Survey Open-File Report 4-75, 39 p.

Jordan, P.R., and Irza, T.J., 1975, Kansas streamflow characteristics, magnitude and frequency of floods in Kansas, unregulated streams: Kansas Water Resources Board Technical Report No. 11, 34 p.

McClain, T.J., Jenkins, E.D., Keene, K.M., and Pabst, M.E., 1975, Water resources of Gove, Logan, and Wallace Counties, west-central Kansas: U.S. Geological Survey Hydrologic Investigations Atlas HA-521, 2 sheets, scales $1: 250,000$ and 1:500,000.

Morton, R.B., and Fader, S.W., 1975, Ground water in the Grand (Neosho) River Basin, Kansas and Oklahoma: U.S. Geological Survey Open-File Report 75-366, $35 \mathrm{p}$.

U.S. Geological Survey 1975a, Water resources data for Kansas-Part 1, Surface water records, 1974: U.S. Geological Survey Water-Data Report, 202 p.

1975b, Water resources data for Kansas-Part 2, Water quality records, 1974: U.S. Geological Survey Water-Data Report, 188 p.

\section{6}

Burns, C.V., Maddy, D.V., Jordan, P.R., and McNellis, J.M., 1976, Kansas streamflow characteristics, physical and climatic characteristics along Kansas streams: Kansas Water Resources Board Technical Report No. 13, 41 p.

Ehlig, Christine, and Halepaska, J.C., 1976, A numerical study of confined-unconfined aquifers including effects of delayed yield and leakage: American Geophysical Union, Water Resources Research, v. 12, no. 6, p. 1175-1183.

Fader, S.W., and Stullken, L.E., 1976, Geohydrologic maps of the Great Bend Prairie, south-central Kansas: U.S. Geological Survey Open-File Report 76-405, 4 sheets, scale 1:250,000.

Gutentag, E.D., and Stullken, L.E., 1976, Ground-water resources of Lane and Scott Counties, western Kansas: Kansas Geological Survey Irrigation Series 1, 37 p.
Leonard, R.B., and Kleinschmidt, M.K., 1976, Saline water in the Little Arkansas River Basin area, southcentral Kansas: Kansas Geological Survey Chemical Quality Series 3, 24 p.

Pabst, M.E., and Jenkins, E.D., 1976a, Water-level changes in northwestern Kansas, 1950-76: Kansas Geological Survey Journal, December 1976, 20 p. 1976b, Water-level changes in southwestern Kansas, 1940-75: Kansas Geological Survey Journal, May 1976, 26 p.

Slagle, S.E., and Weakly, E.C., 1976, Ground-water resources of Greeley and Wichita Counties, western Kansas: Kansas Geological Survey Irrigation Series 2, $21 \mathrm{p}$.

Stullken, L.E., and Fader, S.W., 1976, Hydrogeologic data from the Great Bend Prairie, south-central Kansas: Kansas Geological Survey Basic-Data Series, GroundWater Release 5, $50 \mathrm{p}$.

U.S. Geological Survey, 1976, Water resources data for Kansas, water year 1975: U.S. Geological Survey Water-Data Report KS-75-1, 405 p.

\section{7}

Broeker, M.E., McIntyre, H.J., Jr., and McNellis, J.M., 1977, Ground-water levels in observation wells in Kansas, 1971-75: Kansas Geological Survey BasicData Series, Ground-Water Release 6, $526 \mathrm{p}$.

Fader, S.W., and Stullken, L.E., 1977, Geohydrology of the Great Bend Prairie, south-central Kansas: U.S. Geological Survey Open-File Report 77-305, 53 p.

Gillespie, J.B., Hargadine, G.D., and Stough, M.J., 1977, Artificial-recharge experiments near Lakin, western Kansas: Kansas Water Resources Board Bulletin No. 20,91 p.

Hathaway, L.R., Carr, B.L., Galle, O.K., Magnuson, L.M., Waugh, T.C., and Dickey, H.P., 1977, Chemical quality of irrigation waters in Hamilton, Kearny, Finney, and northern Gray Counties: Kansas Geological Survey Chemical Quality Series 4, 33 p.

Hedman, E.R., and Kastner, W.M., 1977, Streamflow characteristics related to channel geometry in the Missouri River Basin: U.S. Geological Survey Journal of Research, v. 5, no. 3, p. 285-300.

Hejl, H.R., Jr., 1977, A method for adjusting values of Manning's roughness coefficient for flooded urban areas: U.S. Geological Survey Journal of Research, v. 5, no. 5, p. 54I-545.

Jenkins, E.D., and Pabst, M.E., 1977, Water-resources reconnaissance of Ness County, west-central Kansas: Kansas Geological Survey Irrigation Series 3, 26 p. 
Jordan, P.R., 1977, Streamflow transmission losses in western Kansas: Proceedings, American Society Civil Engineers, Hydraulics Division Journal, v. 103, no. HY8, p. 905-919.

Keene, K.M., and Bayne, C.K., 1977, Ground water from Lower Cretaceous rocks in Kansas: Kansas Geological Survey Chemical Quality Series 5, $18 \mathrm{p}$.

McElwee, C.D., 1977, The Theis equation-Evaluation, sensitivity to storage and transmissivity, and automated fit of pump test data: Kansas Geological Survey OpenFile Report 77-5, 38 p.

Osterkamp, W.R., 1977, Fluvial sediment in the Arkansas River Basin, Kansas: Kansas Water Resources Board Bulletin 19,91 p.

Osterkamp, W.R., and Hedman, E.R., 1977, Variation of width and discharge for natural high-gradient stream channels: American Geophysical Union, Water Resources Research, v. 13, no. 2, p. 256-258.

Pabst, M.E., 1977a, January 1977 water levels, and data related to water-level changes since 1950 , western Kansas: U.S. Geological Survey Open-File Report 77-264, 209 p.

$\mathbf{1 9 7 7 b}$, Map showing percentage decline in saturated thickness of unconsolidated aquifer, 1950-77, westcentral Kansas: U.S. Geological Survey Open-File Report 77-675, 1 sheet, scale 1:126,720.

Pabst, M.E., and Gutentag, E.D., 1977, Water-level changes in west-central Kansas, 1950-77: Kansas Geological Survey Journal, October 1977, 18 p.

Prill, R.C., 1977, Movement of moisture in the unsaturated zone in a loess-mantled area, southwestern Kansas: U.S. Geological Survey Professional Paper 1021, 21 p.

U.S. Geological Survey, 1977, Water resources data for Kansas, water year 1976: U.S. Geological Survey Water-Data Report KS-76-1, 395 p.

\section{8}

Carswell, W.J., Jr., 1978a, Description of data-collection system and synopsis of selected hydrologic data for Soldier Creek Basin, Kansas: U.S. Geological Survey Open-File Report 78-678, 80 p.

1978b, Hydrologic data for Soldier Creek Basin, Kansas: U.S. Geological Survey Water-Resources Investigations Report 78-87, $26 \mathrm{p}$.

Fader, S.W., and Stullken, L.E., 1978, Geohydrology of the Great Bend Prairie, south-central Kansas: Kansas Geological Survey Irrigation Series 4, $19 \mathrm{p}$.

Gutentag, E.D., Lobmeyer, D.H., and Slagle, S.E., 1978 , Map showing saturated thickness of the unconsolidated aquifer, southwestern Kansas, January 1975: U.S. Geological Survey Open-File Report 78-80, I sheet, scale 1:250,000.
Hathaway, L.R., Carr, B.L., Flanagan, M.A., Galle, O.K., Waugh, T.C., Dickey, H.P., and Magnuson, L.M., 1978, Chemical quality of irrigation waters in southwestern Kansas: Kansas Geological Survey Chemical Quality Series 6, 35 p.

Hathaway, L.R., Galle, O.K., Waugh, T.C., and Dickey, H.P., 1978, Chemical quality of irrigation waters in Ford County and the Great Bend Prairie of Kansas: Kansas Geological Survey Chemical Quality Series 7, $41 \mathrm{p}$.

Hauth, L.D., and Carswell, W.J., Jr., 1978, Floods in Kansas City, Missouri and Kansas, September 12-13, 1977: U.S. Geological Survey Water-Resources Investigations Report 78-63, 43 p.

Jordan, P.R., 1978a, Loss of high flows by seepage from stream channels in Kansas: Kansas Water News, v. 21 , no. 1 and 2 , p. 30-34.

1978b, Statistical summary of streamflow data for Kansas streams in the Arkansas River Basin: Kansas Water Resources Board Technical Report No. 14A, 206 p.

Lobmeyer, D.H., and Weakly, E.C., 1978, Water in Dakota Formation, Hodgeman and northern Ford Counties, southwestern Kansas: U.S. Geological Survey Open-File Report 78-886, 81 p.

McElwee, C.D., and Yukler, M.R., 1978, Sensitivity of groundwater models with respect to variations in transmissivity and storage: American Geophysical Union, Water Resources Research, v. 14, no. 3, p. $451-459$.

Osterkamp, W.R., 1978a, Bed- and bank-sampling procedure at channel geometry sites: Proceedings of National Conference on Sampling, Validation, and Quality Control of Environmental Measurements, Atlanta, Ga., May 31-June 2, 1978.

$1978 b$, Effect of channel sediment on widthdischarge relations, with emphasis on streams in Kansas: Kansas Water Resources Board Bulletin 21, $25 \mathrm{p}$.

$1978 c$, Gradient, discharge, and particle-size relations of alluvial channels in Kansas, with observations on braiding: American Journal of Science, v. 278, November 1978, p. 1253-1268.

Osterkamp, W.R., McNellis, J.M., and Jordan, P.R., 1978, Guidelines for the use of structural versus regression analysis in geomorphic studies: U.S. Geological Survey Water-Resources Investigation Report 78-135, 22 p.

Pabst, M.E., 1978a, January 1978 water levels, and data related to water-level changes since 1940 or 1950 , western Kansas: U.S. Geological Survey Open-File Report 78-409, 179 p. 
1978b, Map showing percentage decrease in saturated thickness of unconsolidated aquifer, 1950-78, west-central Kansas: U.S. Geological Survey Open-File Report 78-874, 1 sheet, scale $1: 126,720$.

$1978 \mathrm{c}$, Map showing saturated thickness of unconsolidated aquifer, southwestern Kansas, January 1978: U.S. Geological Survey Open-File Report 78-969, 4 sheets, scale 1:125,000.

Peek, C.O., and Jordan, P.R., 1978, Determination of peak discharge from rainfall data for urbanized basins, Wichita, Kansas: U.S. Geological Survey Open-File Report 78-974, 49 p.

U.S. Geological Survey, 1978a, Water resources data for Kansas, water year 1977: U.S. Geological Survey Water-Data Report KS-77-1, 618 p.

$1978 \mathrm{~b}$, Water resources investigations in Kansas: U.S. Geological Survey folder.

$1978 c$, Water resources investigations in Kansas, fiscal year 1977: U.S. Geological Survey, 80 p.

1978d, Water resources investigations in Kansas, 1978: U.S. Geological Survey, Water Index folder.

\section{9}

Baker, C.H., Jr., 1979, Evaluation of methods for estimating ground-water withdrawals in western Kansas: U.S. Geological Survey Water-Resources Investigations Report 79-92, 70 p.

Carswell, W.J., Jr., 1979, Multiyear low flow in southeastern Kansas: U.S. Geological Survey WaterResources Investigations, Open-File Report 79-1288, $26 \mathrm{p}$.

Denne, J.E., 1979, Uncovering buried valleys in northeastern Kansas: Kansas Geological Survey, The Journal, v. 1, no. 3, 4 p.

Hathaway, L.R., Waugh, T.C., Galle, O.K., and Dickey, H.P., 1979, Chemical quality of irrigation waters in northwestern Kansas: Kansas Geological Survey Chemical Quality Series 8,45 p.

Jordan, P.R., 1979a, Relation of sediment yield to climatic and physical characteristics in the Missouri River Basin: U.S. Geological Survey Water-Resources Investigations Report 79-49, 26 p.

1979b, Statistical summary of streamflow data for Kansas streams in the Missouri River Basin: Kansas Water Resources Board Technical Report No. 14B, $334 \mathrm{p}$.

Kume, Jack, Dunlap, L.E., Gutentag, E.D., and Thomas, J.G., 1979, Hydrologic and related data for watersupply in an intensive-study area, northeastern Wichita
County, Kansas: U.S. Geological Survey WaterResources Investigations Report 79-105, 51 p.

Lobmeyer, D.H., and Weakly, E.C., 1979, Water in the Dakota Formation, Hodgeman and northern Ford Counties, southwestern Kansas: Kansas Geological Survey Irrigation Series 5, $41 \mathrm{p}$.

McGovern, H.E., and Combs, L.J., 1979, Water-resources investigations in Kansas-Fiscal year 1978: U.S. Geological Survey Open-File Report 79-561, 85 p.

Osterkamp, W.R., 1979a, Bed- and bank-material sampling procedure at channel-geometry sites National Conference on Quality Assurance of Environmental Measurement, Information Transfer Inc., p. 86-89.

$\mathbf{1 9 7 9 b}$, Invariant power functions as applied to fluvial morphology, in Rhodes, D.D., and Williams, G.R., eds., Adjustments of the fluvial system: Kendall/Hunt Publishing Co., p. 33-54.

1979 c, Variation of alluvial-channel width with discharge and character of sediment: U.S. Geological Survey Water-Resources Investigations Report 79-15, $11 \mathrm{p}$.

Osterkamp, W.R., and Hedman, E.R., 1979, Discharge estimates in surface-mine areas using channelgeometry techniques: Proceedings, Symposium on Surface-Mine Hydrology, Sedimentology and Reclamation, University of Kentucky Bulletin 119 , p. $43-49$.

Pabst, M.E., 1979a, January 1979 water levels, and data related to water-level changes, western and southcentral Kansas: U.S. Geological Survey Open-File Report 79-925, 213 p.

1979b, Maps showing saturated thickness, January 1979, and percentage decrease in saturated thickness, 1950-79, of unconsolidated aquifer, westcentral Kansas: U.S. Geological Survey Open-File Report 79-1340, 2 sheets, scale 1:125,000.

Pabst, M.E., and Gutentag, E.D., 1979, Water-level changes in southwestern Kansas, 1940-78: Kansas Geological Survey Journal, May 1979, 29 p.

Rosenshein, J.S., 1979, Groundwater in the United States 1975-78: American Geophysical Union, Reviews of Geophysics and Space Physics, v. 17, no. 6, September 1979 , p. 1240-1253.

Skougstad, M.W., and others, 1979, Methods for determination of inorganic substances in water and fluvial sediments: U.S. Geological Survey Techniques of Water-Resources Investigations, book 5, chap. Al, $626 \mathrm{p}$.

U.S. Geological Survey, 1979, Water resources data for Kansas, water year 1978: U.S. Geological Survey Water-Data Report KS-78-1, 656 p. 
Stullken, L.E., 1980, Hydrogeologic data from northcentral Kansas: Kansas Geological Survey Basic-Data Series, Ground-Water Release 7, 46 p.

Bevans, H.E., 1980, A procedure for predicting concentrations of dissolved solids and sulfate ion in streams draining areas strip mined for coal: U.S. Geological Survey Water-Resources Investigations, Open-File Report 80-764, $17 \mathrm{p}$.

Bevans, H.E., and Diaz, A.M., 1980, Statistical summary of water-quality data for streams draining coal-mined areas, southeastern Kansas: U.S. Geological Survey Open-File Report 80-350, 113 p.

Carswell, W.J., Jr., and Bond, S.V., 1980, Multiyear low flow of streams in northeastern Kansas: U.S. Geological Survey Water-Resources Investigations, Open-File Report 80-734, 26 p.

Dunlap, L.E., 1980, Simulated water-level declines near Marienthal, west-central Kansas: U.S. Geological Survey Water-Investigations Report 80-39, 15 p.

Dunlap, L.E., Kume, Jack, and Thomas, J.G., 1980, Geohydrology and model analysis for water-supply management in a small area of west-central Kansas: U.S. Geological Survey Water-Resources Investigations Report 80-91, 59 p.

Gutentag, E.D., Lobmeyer, D.H., and Slagle, S.E., 1980, Geohydrology of southwestern Kansas: U.S. Geological Survey Open-File Report 80-218, 97 p.

Heimes, F.J., and Luckey, R.R., 1980, Evaluating methods for determining water use in the High Plains in parts of Colorado, Kansas, Nebraska, New Mexico, Oklahoma, South Dakota, Texas, and Wyoming, 1979: U.S. Geological Survey Water-Resources Investigations Report 80-111, 118 p.

Longwill, S.M., McNellis, J.M., and Posson, D.R., 1980, The use of minicomputers in a distributed information processing system-A feasibility study: U.S. Geological Survey Open-File Report 80-326, 68 p.

Osterkamp, W.R., 1980, Sediment-morphology relations of alluvial channels: American Society Civil Engineers Proceedings, Watershed Management Symposium, Boise, Idaho, 12 p.

Osterkamp, W.R., and Wiseman, A.G., 1980, Particlesize analyses of bed and bank material from channels of the Missouri River Basin: U.S. Geological Survey Hydrologic Data, Open-File Report 80-429, 31 p.

Pabst, M.E., 1980, January 1980 water levels, and data related to water-level changes, western and southcentral Kansas: U.S. Geological Survey Hydrologic Data, Open-File Report 80-958, 166 p.

Perry, C.A., 1980, Preliminary analysis of regionalprecipitation periodicity: U.S. Geological Survey Water-Resources Investigations Report 80-74, 26 p.

U.S. Geological Survey, 1980a, Water resources data for Kansas, water year 1979-Volume 1. Missouri River Basin: U.S. Geological Survey Water-Data Report KS-79-1, 372 p.

$1980 b$, Water resources data for Kansas, water year 1979-Volume 2. Arkansas River Basin: U.S. Geological Survey Water-Data Report KS-79-2, $372 \mathrm{p}$.

\section{1}

Barker, R.A., Dunlap, L.E., and Sauer, C.G., 1981, Analysis and computer simulation of streamaquifer hydrology, Arkansas River Valley, southwestern Kansas: U.S. Geological Survey Open-File Report 81-686, $130 \mathrm{p}$.

Carswell, W.J., Jr., 1981, Selected hydrologic relations for Soldier Creek, northeastern Kansas: U.S. Geological Survey Water-Resources Investigations Report 81-8, $68 \mathrm{p}$.

Dunlap, L.E., and Spinazola, J.M., 1981, Hydrologic maps of Ogallala aquifer, west-central Kansas, 1978-80: U.S. Geological Survey Open-File Report 81-908, 4 sheets, scale $1: 125,000$.

Feder, G.L., and Krothe, N.C., 1981, Results of a reconnaissance water-quality sampling program of the Ogallala aquifer in Colorado, Kansas, Nebraska, Oklahoma, South Dakota, and Texas: U.S. Geological Survey Water-Resources Investigations Report 81-65, $7 \mathrm{p}$.

Gillespie, J.B., and Hargadine, G.D., 1981, Saline ground-water discharge to the Smoky Hill River between Salina and Abilene, central Kansas: U.S. Geological Survey Water-Resources Investigations Report 81-43, $71 \mathrm{p}$.

Gogel, Tony, 1981a, Discharge of saltwater from Permian rocks to major stream-aquifer systems in central Kansas: Kansas Geological Survey Chemical Quality Series $9,60 \mathrm{p}$.

1981b, Preliminary data from Arbuckle test wells, Miami, Douglas, Saline, and Labette Counties, Kansas: U.S. Geological Survey Open-File Report 81-1112, 155 p.

Gutentag, E.D., Lobmeyer, D.H., and Slagle, S.E., 1981, Geohydrology of southwestern Kansas: Kansas Geological Survey Irrigation Series 7, 73 p. 
Hathaway, L.R., Waugh, T.C., Galle, O.K., and Dickey, H.P., 1981, Chemical quality of irrigation waters in the Equus-beds area, south-central Kansas: Kansas Geological Survey Chemical Quality Series 10, 45 p.

Hauth, L.D., Carswell, W.J., Jr., U.S. Geological Survey, and Chin, E.H., National Weather Service, National Oceanic and Atmospheric Administration, 1981, Floods in Kansas City, Missouri and Kansas, September 12-13, 1977: U.S. Geological Survey Professional Paper 1169, $47 \mathrm{p}$.

Jorgensen, D.G., and Signor, D.C., 1981, Plan of study for the Central Midwest Regional aquifer system analysis in parts of Arkansas, Colorado, Kansas, Missouri, Nebraska, New Mexico, Oklahoma, South Dakota, and Texas: U.S. Geological Survey Water-Resources Investigations, Open-File Report 81-206, 28 p.

Jorgensen, D.G., and Stullken, L.E., 1981, Hydrology and model of North Fork Solomon River Valley, Kirwin Dam to Waconda Lake, north-central Kansas: Kansas Geological Survey Irrigation Series 6, 34 p.

McGovern, H.E., and Combs, L.J., 1981, Water-resources investigations of the U.S. Geological Survey in Kansas-Fiscal years 1979 and 1980: U.S. Geological Survey Water-Resources Investigations, Open-File Report 81-348, 107 p.

Osterkamp, W.R., Curtis, R.E., Jr., and Crowther, H.G., 1981, Sediment and channel-geometry investigations for the Kansas River Bank-Stabilization Study, Kansas, Nebraska, and Colorado: U.S. Geological Survey Water-Resources Investigations, Open-File Report 81-128, 72 p.

Osterkamp, W.R., and Hedman, E.R., 1981, Channel geometry of regulated streams in Kansas as related to mean discharge, 1970-80: Kansas Water Office Technical Report No. 15, 32 p.

Pabst, M.E., 1981, January 1981 water levels and data related to water-level changes, western and southcentral Kansas: U.S. Geological Survey Open-File Report 81-1001, 168 p.

Pabst, M.E., and Stullken, L.E., 1981, Altitude and configuration of the water table in the High Plains aquifer in Kansas, 1980: U.S. Geological Survey Water-Resources Investigations Report 85-4009, 1 sheet, scale 1:500,000.

Perry, C.A., 1981, Regional precipitation periodicity, in Proceedings of Fourth Conference on Hydrometeorology, Reno, Nev., October 7-9, 1981: American Meteorological Society, session 1B, p. 45-50.

Reed, T.B., 1981, Map of water table in Solomon River Valley, Waconda Lake to Solomon, north-central Kansas, May 1980: U.S. Geological Survey WaterResources Investigations, Open-File Report 81-334, 1 sheet, scale 1:125,000.
Spinazola, J.M., 1981, Map of water table in Graham County, northwestern Kansas, March 1979: U.S. Geological Survey Water-Resources Investigations, Open-File Report 81-333, 1 sheet, scale 1:125,000.

Spruill, T.B., and Kenny, J.F., 1981, Location of sampling sites and available information on wells sampled in the Kansas Ground-Water-Quality Monitoring Network, 1976-80: U.S. Geological Survey Hydrologic Data, Open-File Report 81-925, 49 p.

Stullken, L.E., and Pabst, M.E., 1981, Altitude and configuration of water table in High Plains regional aquifer of Kansas, 1975: U.S. Geological Survey Open-File Report 81-144, 1 sheet, scale 1:500,000.

U.S. Geological Survey, 1981a, Water resources data for Kansas, water year 1980-Volume 1. Missouri River Basin: U.S. Geological Survey Water-Data Report KS-80-1, 422 p.

1981b, Water resources data for Kansas, water year 1980 - Volume 2. Arkansas River Basin: U.S. Geological Survey Water-Data Report KS-80-2, $340 \mathrm{p}$.

\section{2}

Bevans, H.E., 1982, Water-quality and fluvial-sediment characteristics of selected streams in northeast Kansas: U.S. Geological Survey Water-Resources Investigations Report 82-4005, $53 \mathrm{p}$.

Carswell, W.J., Jr., 1982, Storage requirements to sustain gross reservoir outflow from small basins in Kansas: Kansas Water Office Technical Report No. 16, 40 p.

Clement, R.W., and Johnson, D.G., 1982, Flood of June 15, 1981, in Great Bend and vicinity, central Kansas: U.S. Geological Survey Water-Resources Investigations Report 82-4123, 9 p.

Dunlap, L.E., 1982, Geohydrology of principal aquifers in the Republican River Basin, Kansas: U.S. Geological Survey Open-File Report 82-79, 5 sheets, scale $1: 250,000$.

Hedman, E.R., and Osterkamp, W.R., 1982, Streamflow characteristics related to channel geometry of streams in western United States: U.S. Geological Survey Water-Supply Paper 2193, 17 p.

Heidari, Manoutchehr, 1982, Groundwater management options for the Pawnee Valley of south-central Kansas: Kansas Geological Survey Ground-Water Series 4, $56 \mathrm{p}$.

Helgesen, J.O., Jorgensen, D.G., Leonard, R.B., and Signor, D.C., 1982, Regional study of the Dakota aquifer (Darton's Dakota revisited): Ground Water, v. 20, no. 4 , p. $410-414$. 
Jordan, P.R., 1982, Rainfall-runoff relations and expected streamflow in western Kansas: Kansas Water Office Bulletin 25, 42 p.

Jorgensen, D.G., Gogel, Tony, and Signor, D.C., 1982, Determination of flow in aquifers containing variabledensity water, in Ground Water Monitoring Review: Worthington, Ohio, Water Well Journal Publishing Co., v. 2, no. 2, Spring 1982, p. 40-45.

Jorgensen, D.G., Grubb, H.F., Baker, C.H., Jr., Hilmes, G.E., and Jenkins, E.D., 1982, A numerical model to evaluate proposed ground-water allocations in southwest Kansas: U.S. Geological Survey WaterResources Investigations Report 82-4095, 46 p.

Kenny, J.F., Bevans, H.E., and Diaz, A.M., 1982, Physical and hydrologic environments of the Mulberry coal reserves in eastern Kansas: U.S. Geological Survey Water-Resources Investigations Report 82-4074, $50 \mathrm{p}$.

Kenny, J.F., and McCauley, J.R., 1982, Remote-sensing investigations in the coal fields of southeastern Kansas, in Johannsen, C.J., and Sanders, J.L., eds., chap. 29 of Remote sensing for resource management (outgrowth of a national conference by the same name, held October 28-30, 1980, at Kansas City, Mo., 665 p.): Ankeny, Iowa, Soil Conservation Society of America, p. 338-346.

Krothe, N.C., and Oliver, J.W., 1982, Sulfur isotopic composition and water chemistry in water from the High Plains aquifer, Oklahoma Panhandle and southwestern Kansas: U.S. Geological Survey WaterResources Investigations Report 82-12, 28 p.

Krothe, N.C., Oliver, J.W., and Weeks, J.B., 1982, Dissolved solids and sodium in water from the High Plains aquifer in parts of Colorado, Kansas, Nebraska, New Mexico, Oklahoma, South Dakota, Texas, and Wyoming: U.S. Geological Survey Hydrologic Investigations Atlas HA-658, 2 sheets, scale $1: 2,500,000$.

Kume, Jack, and Spinazola, J.M., 1982, Geohydrologic data from sandstone aquifers in southwestern Kansas: U.S. Geological Survey Open-File Report 82-868, $112 \mathrm{p}$.

Lindgren, R.J., 1982, Determination of irrigation pumpage in parts of Kearny and Finney Counties, southwestern Kansas: U.S. Geological Survey Water-Resources Investigations Report 82-4011, 26 p.

Osterkamp, W.R., and Hedman, E.R., 1982, Perennialstreamflow characteristics related to channel geometry and sediment in Missouri River Basin: U.S. Geological Survey Professional Paper 1242, 37 p.

Osterkamp, W.R., Hedman, E.R., and Wiseman, A.G., 1982, Geometry, basin characteristics, discharge, and particle-size data from gaged stream-channel sites, western United States: U.S. Geological Survey Hydrologic Data, Open-File Report 82-93, 56 p.

Pabst, M.E., 1982a, January 1982 water levels and data related to water-level changes, western and southcentral Kansas: U.S. Geological Survey Open-File Report 82-649, 167 p.

1982b, Map showing percentage change in saturated thickness of the High Plains aquifer, west-central Kansas, 1950 to average 1980-82: U.S. Geological Survey Open-File Report 82 1010, 1 sheet, scale $1: 125,000$.

Pabst, M.E., and Stullken, L.E., 1982, Altitude and configuration of the water table in the High Plains aquifer of Kansas, pre-1950: U.S. Geological Survey Open-File Report 82-117, 1 sheet, scale 1:500,000.

Pope, L.M., and Diaz, A.M., 1982, Quality-of-water data and statistical summary for selected coal-mine strip pits in Crawford and Cherokee Counties, southeastern Kansas: U.S. Geological Survey Open-File Report 82-1021, 28 p.

Spinazola, J.M., 1982a, Hydrologic maps of the High Plains aquifer, January 1981, southwestern Kansas: U.S. Geological Survey Water-Resources Investigations Report 82-4079, 8 sheets, scale 1:125,000.

1982b, Hydrologic maps of the Ogallala aquifer, west-central Kansas, 1979-81: U.S. Geological Survey Open-File Report 82-258, 4 sheets, scale 1:125,000.

Spruill, T.B., 1982, Nitrate-nitrogen concentrations in ground water from three selected areas in Kansas: U.S. Geological Survey Water-Resources Investigations Report 82-11, $32 \mathrm{p}$.

Stullken, L.E., and Pabst, M.E., 1982, Altitude and configuration of the water table in the High Plains aquifer of Kansas, pre-1950: U.S. Geological Survey Open-File Report 82-117, 1 sheet, scale 1:500,000.

U.S. Geological Survey, 1982, Water resources data for Kansas, water year 1981: U.S. Geological Survey Water-Data Report KS-81-1, 566 p.

\section{3}

Baker, C.H., Jr., 1983, Evaluation of techniques for estimating ground-water withdrawals for irrigation in western Kansas: Kansas Water Office Bulletin 26, $14 \mathrm{p}$.

Barker, R.A., Dunlap, L.E., and Sauer, C.G., 1983, Analysis and computer simulation of stream-aquifer hydrology, Arkansas River Valley, southwestern Kansas: U.S. Geological Survey Water-Supply Paper 2200, $59 \mathrm{p}$. 
Clement, R.W., 1983, Improvement of flood-frequency estimates for selected small watersheds in eastern Kansas using a rainfall-runoff model: U.S. Geological Survey Water-Resources Investigations Report 83-4110, 22 p.

Dunlap, L.E., Lindgren, R.J., and Sauer, C.A., 1983, Geohydrology and model analysis of stream-aquifer system along the Arkansas River in Kearny and Finney Counties, southwestern Kansas: U.S. Geological Survey Open-File Report 83-222, 84 p.

Geiger, C.O., Lacock, D.L., Shelton, L.R., Penny, M.L., and Merry, C.E., 1983, Water resources data, Kansas, water year 1982: U.S. Geological Survey Water-Data Report KS-82-1, 485 p.

Heimes, F.J., and Luckey, R.R., 1983, Estimating 1980 ground-water pumpage for irrigation on the High Plains in parts of Colorado, Kansas, Nebraska, New Mexico, Oklahoma, South Dakota, Texas, and Wyoming: U.S. Geological Survey Water-Resources Investigations Report 83-4123, 36 p.

Jordan, P.R., 1983, Magnitude and frequency of low flows of unregulated streams in Kansas, and estimation of flow-duration curves for ungaged sites: Kansas Water Office Technical Report No. 17, $55 \mathrm{p}$.

Kenny, J.F., and Combs, L.J., 1983, Water-resources investigations of the U.S. Geological Survey in Kansas-Fiscal years 1981 and 1982: U.S. Geological Survey Open-File Report 83-932, 87 p.

Kenny, J.F., and McCauley, J.R., 1983, Application of remote-sensing techniques to hydrologic studies in selected coal-mined areas of southeastern Kansas: U.S. Geological Survey Water-Resources Investigations Report 83-4007, 33 p.

Kume, Jack, and Spinazola, J.M., 1983, Depth and thickness of selected units in Upper Permian, Upper Jurassic, and Lower Cretaceous rocks in southwestern Kansas: U.S. Geological Survey Water-Resources Investigations Report 83-4095, 7 sheets, scale 1:500,000.

Leonard, R.B., Signor, D.C., Jorgensen, D.G., and Helgesen, J.O., 1983, Geohydrology and hydrochemistry of the Dakota aquifer, central United States: American Water Resources Association, Water Resources Bulletin, v. 19, no. 6, December 1983, p. 903-911.

Pabst, M.E., 1983a, January 1983 water levels and data related to water-level changes, western and southcentral Kansas: U.S. Geological Survey Open-File Report 83-762, 164 p.

1983b, Kansas ground-water observation-well network, 1983: U.S. Geological Survey Open-File Report 83-528, $57 \mathrm{p}$.
Pope, L.M., Diaz, A.M., and Butler, M.K., 1983, Urban water-quality data and statistical summaries for selected sites in the Shunganunga Creek Basin, Topeka, Kansas: Kansas Department of Health and Environment Bulletin B2-49, 203 p.

Spinazola, J.M., and Dealy, M.T., 1983, Hydrology of the Ogallala aquifer in Ford County, southwestern Kansas: U.S. Geological Survey Water-Resources Investigations Report 83-4226, 58 p.

Spruill, T.B., 1983a, Relationship of nitrate concentrations to distance of well screen openings below casing water levels: American Water Resources Association, Water Resources Bulletin, v. 19, no. 6, December 1983, p. 977-981.

1983b, Statistical summaries of selected chemical constituents in Kansas ground-water supplies, 1976-81: U.S. Geological Survey Open-File Report 83-263, 29 p.

\section{4}

Bevans, H.E., 1984, Hydrologic responses of streams to mining of the Mulberry Coal reserves in eastern Kansas: U.S. Geological Survey Water-Resources Investigations Report 84-4047, 29 p.

Bevans, H.E., Skelton, John, Kenny, J.F., and Davis, J.V., 1984, Hydrology of area 39, Western Region, Interior Coal Province, Kansas and Missouri: U.S. Geological Survey Water-Resources Investigations, Open-File Report 83-851, 83 p.

Burnett, R.D., 1984, Predictive simulations of alternatives for managing the water resources of North Fork Solomon River Valley between Kirwin Dam and Waconda Lake, north-central Kansas: U.S. Geological Survey Water-Resources Investigations Report 84-4249, $34 \mathrm{p}$.

Combs, L.J., compiler, 1984, Water-resources reports prepared by or in cooperation with the U.S. Geological Survey in Kansas, 1886-1983: U.S. Geological Survey Open-File Report 84-609, 117 p.

Dealy, M.T., Kume, Jack, and Jenkins, E.D., 1984, Hydrogeology and development of the Dakota aquifer in southwest Kansas, in Jorgensen, D.G., and Signor, D.C., eds., Geohydrology of the Dakota aquifer: National Water Well Association, Proceedings of the First C.V. Theis Conference on Geohydrology, Lincoln, Nebr., October 5-6, 1982, p. 209-220.

Dunlap, L.E., Lindgren, R.J., and Carr, J.E., 1984, Projected effects of ground-water withdrawals in the Arkansas River Valley, 1980-99, Hamilton and Kearny Counties, southwestern Kansas: U.S. Geological Survey Water-Resources Investigations Report 84-4082, 168 p. 
Dunlap, L.E., and Spinazola, J.M., 1984, Interpolating water-table altitudes in west-central Kansas using kriging techniques: U.S. Geological Survey WaterSupply Paper 2238, 19 p.

Geiger, C.O., Lacock, D.L., Shelton, L.R., Penny, M.L., and Merry, C.E., 1984, Water resources data, Kansas, water year 1983: U.S. Geological Survey Water-Data Report KS-83-1, 483 p.

Gutentag, E.D., Heimes, F.J., Krothe, N.C., Luckey, R.R., and Weeks, J.B., 1984, Geohydrology of the High Plains aquifer in parts of Colorado, Kansas, Nebraska, New Mexico, Oklahoma, South Dakota, Texas, and Wyoming: U.S. Geological Survey Professional Paper 1400-B, 63 p.

Hart, R.J., and Stiles, T.C., 1984, Availability of natural and regulated streamflows for instream uses during historical droughts, lower Neosho River, southeastern Kansas: U.S. Geological Survey Water-Resources Investigations Report 84-4292, 42 p.

Jordan, P.R., 1984, Magnitude and frequency of high flows of unregulated streams in Kansas: U.S. Geological Survey Open-File Report 84-453, 45 p.

Kume, Jack, 1984, Geohydrology and chemical quality of water in Middle and Upper Jurassic and Lower Cretaceous rocks, western Kansas: U.S. Geological Survey Water-Resources Investigations Report 84-4045, 54 p.

Livingston, R.K., and Medina, K.D., 1984, Water-data program of the U.S. Geological Survey in Kansas, fiscal year 1983: U.S. Geological Survey WaterResources Investigations Report 84-4306, 33 p.

Marcher, M.V., Kenny, J.F., and others, 1984, Hydrology of area 40, Western Region, Interior Coal Province, Kansas, Oklahoma, and Missouri: U.S. Geological Survey Water-Resources Investigations, Open-File Report 83-266, 97 p.

McGovern, H.E., 1984, Overview of the Dakota aquifer in Kansas, in Jorgensen, D.G., and Signor, D.C., eds., Geohydrology of the Dakota aquifer: National Water Well Association, Proceedings of First C.V. Theis Conference on Geohydrology, Lincoln, Nebr., October 5-6, 1982, p. 58-61.

Medina, K.D., and Geiger, C.O., 1984, Evaluation of the cost effectiveness of the 1983 stream-gaging network in Kansas: U.S. Geological Survey Water-Resources Investigations Report 84-4107, 57 p.

Pabst, M.E., and Dague, B.J., 1984a, January 1984 water levels and data related to water-level changes in western and south-central Kansas: U.S. Geological Survey Open-File Report 84-613, 162 p.

$1984 \mathrm{~b}$, Percentage change in saturated thickness of the High Plains aquifer, west-central Kansas, 1950 to average 1982-84: U.S. Geological Survey WaterResources Investigations Report 84-4357, 1 sheet, scale 1:125,000.
Perry, C.A., 1984a, A method of estimating flood volumes in western Kansas: U.S. Geological Survey WaterResources Investigations Report 84-4164, 18 p.

$1984 \mathrm{~b}$, Natural ground-water-recharge data from three selected sites in Harvey County, south-central Kansas: U.S. Geological Survey Open-File Report 84-457, 31 p.

Perry, C.A., and Hart, R.J., 1984, Flood-frequency estimates for five gaged basins in Wichita, Kansas: U.S. Geological Survey Water-Resources Investigations Report 84-4038, 23 p.

Pope, L.M., and Bevans, H.E., 1984, Relation of urban land-use and dry-weather, storm, and snowmelt flow characteristics to stream-water quality, Shunganunga Creek Basin, Topeka, Kansas: U.S. Geological Survey Open-File Report 84-750, 64 p.

Rosenshein, J.S., and Bennett, G.D., eds., 1984, Groundwater hydraulics: American Geophysical Union, Water Resources Monograph 9, 407 p.

Sophocleous, Marios, and Perry, C.A., 1984, Experimental studies in natural ground-water-recharge dynamics-Assessment of recent advances in instrumentation: Journal of Hydrology, v. 70, p. 369-382.

Spruill, T.B., 1984a, Assessment of water resources in lead-zinc mined areas in Cherokee County, Kansas, and adjacent areas: U.S. Geological Survey Open-File Report 84-439, 102 p.

$1984 \mathrm{~b}$, Use of data from regional ground-waterquality monitoring networks [abs.]: 29th Annual Midwest Ground-Water Conference, Proceedings, Lawrence, Kans., October 1-3, 1984, p. 12.

Stullken, L.E., 1984, Hydrology of Prairie Dog Creek Valley, Norton Dam to state line, north-central Kansas: U.S. Geological Survey Water-Resources Investigations Report 84-4162, $49 \mathrm{p}$.

1985

Bevans, H.E., Spruill, T.B., and Kenny, J.F., 1985, Ground-water resources-Kansas, in National water summary 1984-Hydrologic events, selected waterquality trends, and ground-water resources: U.S. Geological Survey Water-Supply Paper 2275, p. 217-222.

Burnett, R.D., and Reed, T.B., 1985, Simulation of the effects of management alternatives of the streamaquifer system, South Fork Solomon River Valley between Webster Reservoir and Waconda Lake, northcentral Kansas: U.S. Geological Survey WaterResources Investigations Report 85-4200, 19 p. 
Carswell, W.J., Jr., and Hart, R.J., 1985, Transit losses and travel times during drought conditions along the Neosho River from Council Grove Lake to Iola, eastcentral Kansas: U.S. Geological Survey WaterResources Investigations Report 85-4003, $40 \mathrm{p}$.

Combs, L.J., compiler, 1985, Water-resources activities of the U.S. Geological Survey in Kansas-Fiscal years 1983 and 1984: U.S. Geological Survey Open-File Report 85-178, $97 \mathrm{p}$.

Dague, B.J., 1985a, January 1985 water levels, and data related to water-level changes in western and southcentral Kansas: U.S. Geological Survey Open-File Report 85-423, 162 p.

1985b, Percentage change in saturated thickness of the High Plains aquifer, west-central Kansas, 1950 to average 1983-85: U.S. Geological Survey WaterResources Investigations Report 85-4255, 1 sheet, scale 1:125,000.

Dunlap, L.E., Lindgren, R.J., and Sauer, C.G., 1985, Geohydrology and model analysis of stream-aquifer system along the Arkansas River in Kearny and Finney Counties, southwestern Kansas: U.S. Geological Survey Water-Supply Paper 2253, 52 p.

Geiger, C.O., Lacock, D.L., Shelton, L.R., Penny, M.L., and Merry, C.E., 1985, Water resources data, Kansas, water year 1984: U.S. Geological Survey Water-Data Report KS-84-1, 500 p.

Huntzinger, T.L., 1985, Federal-State Cooperative Program in Kansas, seminar proceedings, July 1985: U.S. Geological Survey Open-File Report 85-641, $39 \mathrm{p}$.

Jordan, P.R., 1985, Design of a sediment data-collection program in Kansas as affected by time trends: U.S. Geological Survey Water-Resources Investigations Report 85-4204, 114 p.

Jordan, P.R., and Hart, R.J., 1985, Transit losses and travel times for water-supply releases from Marion Lake during drought conditions, Cottonwood River, east-central Kansas: U.S. Geological Survey WaterResources Investigations Report 85-4263, $41 \mathrm{p}$.

Kume, Jack, Lindgren, R.J., and Stullken, L.E., 1985, Projected ground-water development, ground-water levels, and stream-aquifer leakage in the South Fork Solomon River Valley between Webster Reservoir and Waconda Lake, north-central Kansas, 1979-2020: U.S. Geological Survey Water-Resources Investigations Report 85-4216, 42 p.

Kume, Jack, and Spinazola, J.M., 1985, Geohydrology of sandstone aquifers in southwestern Kansas: Kansas Geological Survey Irrigation Series 8, $49 \mathrm{p}$.

Pabst, M.E., and Stullken, L.E., 1985, Altitude and configuration of the water table in the High Plains aquifer in Kansas, 1970: U.S. Geological Survey Open-File Report 82-448, 1 sheet, scale 1:500,000.
Perry, C.A., and Hart, R.J., 1985, Installation of observation wells on hazardous-waste sites in Kansas using a hollow-stem auger: Ground Water Monitoring Review, Fall 1985, v. 5, no. 4, p. 70-73.

Pope, L.M., Arruda, J.A., and Vahsholtz, A.E., 1985, Water-quality reconnaissance of selected water-supply lakes in eastern Kansas: U.S. Geological Survey Water-Resources Investigations Report 85-4058, $47 \mathrm{p}$.

Reed, T.B., and Burnett, R.D., 1985, Compilation and analyses of aquifer-performance tests in eastern Kansas: U.S. Geological Survey Open-File Report 85-200, $125 \mathrm{p}$.

Sophocleous, Marios, and Perry, C.A., 1985, Experimental studies in natural ground-water-recharge dynamics-The analysis of observed recharge events: Journal of Hydrology, v. 81, p. 297-332.

Spinazola, J.M., Gillespie, J.B., and Hart, R.J., 1985, Ground-water flow and solute transport in the Equusbeds area, south-central Kansas, 1940-79: U.S. Geological Survey Water-Resources Investigations Report 85-4336, 68 p.

Spruill, T.B., 1985, Statistical evaluation of the effects of irrigation on chemical quality of ground water and base flow in three river valleys in north-central Kansas: U.S. Geological Survey Water-Resources Investigations Report 85-4156, 64 p.

Stullken, L.E., Watts, K.R., and Lindgren, R.J., 1985, Geohydrology of the High Plains aquifer, western Kansas: U.S. Geological Survey Water-Resources Investigations Report 85-4198, $86 \mathrm{p}$.

U.S. Geological Survey, 1985, The National Gazetteer of the United States of America-Kansas 1984, prepared by the U.S. Geological Survey in cooperation with the U.S. Board on Geographic Names: U.S. Geological Survey Professional Paper 1200-KS, 326 p.

Watts, K.R., 1985, Potential hydrologic effects of groundwater withdrawals from the Dakota aquifer, southwestern Kansas: U.S. Geological Survey WaterSupply Paper 2304, 72 p.

Watts, K.R., and Stullken, L.E., 1985, Generalized configuration of the base of the High Plains aquifer in Kansas: U.S. Geological Survey Open-File Report 81-344, I sheet, scale 1:500,000.

\section{6}

Bevans, H.E., 1986, Estimating stream-aquifer interactions in coal areas of eastern Kansas by using streamflow records, in Seymour Subitzky, ed., Selected papers in the hydrologic sciences, 1986: U.S. Geological Survey Water-Supply Paper 2290, p. 51-64. 
Burnett, R.D., and Reed, T.B., 1986, Availability of water for irrigation in the South Fork Solomon River Valley, Webster Reservoir to Waconda Lake, north-central Kansas: U.S. Geological Survey Water-Resources Investigations Report 86-4064, 89 p.

Carr, J.E., McGovern, H.E., and Gogel, Tony, 1986, Geohydrology of and potential for fluid disposal in the Arbuckle aquifer in Kansas, with a section on Log analysis of the Arbuckle aquifer, by J.H. Doveton: U.S. Geological Survey Open-File Report 86-491, $101 \mathrm{p}$.

Dague, B.J., 1986a, January 1986 water levels, and data related to water-level changes, western and southcentral Kansas: U.S. Geological Survey Open-File Report 86-317, $165 \mathrm{p}$.

1986b, Percentage change in saturated thickness of the High Plains aquifer, west-central Kansas, 1950 to average 1984-86: U.S. Geological Survey WaterResources Investigations Report 86-4365, 1 sheet, scale 1:125,000.

Dague, B.J., and Stullken, L.E., 1986, Kansas groundwater observation-well network, 1985: U.S. Geological Survey Open-File Report 86-231, 51 p.

Dugan, J.T., 1986, Hydrologic characteristics of soils in parts of Arkansas, Colorado, Kansas, Missouri, Nebraska, New Mexico, Oklahoma, South Dakota, and Texas: U.S. Geological Survey Hydrologic Investigations Atlas HA-678, 1 sheet, scale 1:1,500,000.

Geiger, C.O., Lacock, D.L., Putnam, J.E., Riche, B.L., and Merry, C.E., 1986, Water resources data, Kansas, water year 1985: U.S. Geological Survey Water-Data Report KS-85-1, 478 p.

Gillespie, J.B., and Hargadine, G.D., 1986, Geohydrology of the Wellington-alluvial aquifer system and evaluation of possible locations of relief wells to decrease saline ground-water discharge to the Smoky Hill and Solomon Rivers, central Kansas: U.S. Geological Survey Water-Resources Investigations Report 86-4110, 31 p.

Jordan, P.R., 1986a, Kansas surface-water resources, in Moody, D.W., Chase, E.B., and Aronson, D.A., compilers, National water summary 1985-Hydrologic events and surface-water resources: U.S. Geological Survey Water-Supply Paper 2300, p. 237-244.

1986b, Magnitude and frequency of high flows of unregulated streams in Kansas: U.S. Geological Survey Water-Supply Paper 2280, 35 p.

Jorgensen, D.G., Helgesen, J.O., Leonard, R.B., and Signor, D.C., 1986, Equivalent freshwater head and dissolved-solids concentration of water in rocks of Cambrian, Ordovician, and Mississippian age in the northern Midcontinent, U.S.A.: U.S. Geological
Survey Miscellaneous Field Studies Map MF -1835-B, 2 sheets, scale 1:1,000,000.

Kenny, J.F., 1986, Water demands in Kansas, 1944-84: U.S. Geological Survey Water-Resources Investigations Report 86-4038, 17 p.

Pabst, M.E., and Stullken, L.E., 1986, Altitude and configuration of water table in High Plains aquifer in Kansas, 1960: U.S. Geological Survey Open-File Report 82-429, 1 sheet, scale 1:500,000.

Rosenshein, J.S., Moore, J.E., Lohman, S.W., and Chase, E.B., eds., 1986, Two hundred years of hydrogeology in the United States: U.S. Geological Survey OpenFile Report 86-480, 110 p.

\section{7}

Baker, C.H., Jr., and Hansen, C.V., 1987, Kansas groundwater quality: U.S. Geological Survey Open-File Report 87-726, 7 p.

Clement, R.W., 1987, Floods in Kansas and techniques for estimating their magnitude and frequency on unregulated streams: U.S. Geological Survey WaterResources Investigations Report 87-4008, $50 \mathrm{p}$.

Combs, L.J., compiler, 1987, Water-resources activities of the U.S. Geological Survey in Kansas-Fiscal years 1985 and 1986: U.S. Geological Survey Open-File Report 87-211, 108 p.

Dague, B.J., 1987a, January 1987 water levels, and data related to water-level changes, western and southcentral Kansas: U.S. Geological Survey Open-File Report 87-241, $161 \mathrm{p}$.

$1987 \mathrm{~b}$, Percentage change in saturated thickness of the High Plains aquifer, west-central Kansas, 1950 to average 1985-87: U.S. Geological Survey WaterResources Investigations Report 87-4252, 1 sheet, scale 1:125,000.

Geiger, C.O., Lacock, D.L., Putnam, J.E., Merry, C.E., and Schneider, D.R., 1987, Water resources data, Kansas, water year 1986: U.S. Geological Survey Water-Data Report KS-86-1, 482 p.

Hedman, E.R., Skelton, John, and Freiwald, D.A., 1987, Flow characteristics for selected springs and streams in the Ozark subregion, Arkansas, Kansas, Missouri, and Oklahoma: U.S. Geological Survey Hydrologic Investigations Atlas $\mathrm{HA}-688$, 4 sheets, scale $1: 750,000$

Medina, K.D., 1987a, Analysis of surface-water data network in Kansas for effectiveness in providing regional streamflow information, with a section on Theory and application of generalized least squares, by G.D. Tasker: U.S. Geological Survey Water-Supply Paper 2303, 28 p. 
$1987 \mathrm{~b}$, Floodflow characteristics at proposed bridge site for State Highway 99, Kansas River at Wamego, Kansas: U.S. Geological Survey Open-File Report 87-470, $13 \mathrm{p}$.

Pabst, M.E., and Stullken, L.E., 1987, Altitude and configuration of the water table in the High Plains aquifer in Kansas, 1965: U.S. Geological Survey Open-File Report 82-449, 1 sheet, scale 1:500,000.

Perry, C.A., 1987, Solar-activity harmonics and world climate [abs.]: EOS, Transactions of the American Geophysical Union, v. 68 , no. 44, November 3, 1987, p. 1269.

Pope, L.M., and Bevans, H.E., 1987, Relation of urban land-use and dry-weather, storm, and snowmelt flow characteristics to stream-water quality, Shunganunga Creek Basin, Topeka, Kansas: U.S. Geological Survey Water-Supply Paper 2283, 39 p.

Sophocleous, Marios, and Perry, C.A., 1987, Measuring and computing natural ground-water recharge at sites in south-central Kansas: U.S. Geological Survey Water-Resources Investigations Report 87-4097, 48 p.

Spinazola, J.M., Hansen, C.V., Underwood, E.J., Kenny, J.F., and Wolf, R.J., 1987, Index to selected machinereadable geohydrologic data for Precambrian through Cretaceous rocks in Kansas: U.S. Geological Survey Open-File Report 87-396, 31 p.

Spruill, T.B., 1987a, A proposed method for design of a network to describe non-normally distributed groundwater-quality characteristics [abs.]: EOS, Transactions of the American Geophysical Union, v. 68, no. 16, April 21, 1987, p. 313.

$1987 \mathrm{~b}$, Assessment of water resources in lead-zinc mined areas in Cherokee County, Kansas, and adjacent areas: U.S. Geological Survey Water-Supply Paper 2268, $68 \mathrm{p}$.

Stamer, J.K., Jordan, P.R., Engberg, R.A., and Dugan, J.T., 1987. Surface-water-quality assessment of the lower Kansas River Basin, Kansas and Nebraska-Project description: U.S. Geological Survey Open-File Report 87-105, 36 p.

Stullken, L.E., Stamer, J.K., and Carr, J.E., 1987, Reconnaissance of water quality in the High Plains aquifer beneath agricultural lands, south-central Kansas: U.S. Geological Survey Water-Resources Investigations Report 87-4003, 25 p.

\section{8}

Baker, C.H., Jr., and Hansen, C.V., 1988, Kansas groundwater quality, in Moody, D.W., Carr, Jerry, Chase, E.B., and Paulson, R.W., compilers, National water summary 1986-Hydrologic events and ground-water quality: U.S. Geological Survey Water-Supply Paper 2325, p. 259-264.

Bevans, H.E., 1988, Water supply and demand in Sedgwick County, Kansas: U.S. Geological Survey Open-File Report 88-711 (Water Fact Sheet), 2 p.

Combs, L.J., and Huntzinger, T.L., 1988, U.S. Geological Survey ground-water studies in Kansas: U.S. Geological Survey Open-File Report 88-160 (Water Fact Sheet), 2 p.

Geiger, C.O., Lacock, D.L., Putnam, J.E., Merry, C.E., and Schneider, D.R., 1988, Water resources data, Kansas, water year 1987: U.S. Geological Survey Water-Data Report KS-87-1, 492 p.

Gillespie, J.B., and Perry, C.A., 1988, Channel infiltration from floodflows along the Pawnee River and its tributaries, west-central Kansas: U.S. Geological Survey Water-Resources Investigations Report 88-4055, $30 \mathrm{p}$.

Hart, R.J., and Spruill, T.B., 1988, Description and hydrologic evaluation of nine hazardous-waste sites in Kansas, 1984-86: U.S. Geological Survey WaterResources Investigations Report 88-4015, $73 \mathrm{p}$.

Helgesen, J.O., and Leonard, R.B., 1988, Geohydrology of the Great Plains aquifer system, central United States, in Abstracts of Twenty-Fourth Annual Conference, Water Years Ahead-Quality and Quantity, 1990 and Beyond: American Water Resources Association, Milwaukee, Wisc., November 6-8, 1988, p. 49.

Helgesen, J.O., and Thurman, E.M., 1988, Trace organic compounds in ground water in south-central Kansas as inferred from gas chromatography with flameionization detection, in Preprints of papers presented at the 196th ACS National Meeting: American Chemical Society, Los Angeles, Calif., September 25-30, 1988, v. 28 , no. 2 , p. $9-12$.

Huntzinger, T.L., and Stullken, L.E., 1988, An experiment in representative ground-water sampling for water-quality analysis: U.S. Geological Survey Water-Resources Investigations Report 88-4178, 12 p.

Jorgensen, D.G., 1988a, Estimating permeability in water-saturated formations: The Log Analyst, November-December 1988, p. 401-409.

$\mathbf{1 9 8 8 b}$, Using geophysical logs to estimate porosity, water resistivity, and intrinsic permeability: U.S. Geological Survey Water-Supply Paper 2321, 24 p.

Luckey, R.R., Gutentag, E.D., Heimes, F.J., and Weeks, J.B., 1988, Effects of future ground-water pumpage on the High Plains aquifer in parts of Colorado, Kansas, Nebraska, New Mexico, Oklahoma, South Dakota, Texas and Wyoming: U.S. Geological Survey Professional Paper 1400-E, 44 p. 
Pabst, B.J., 1988, January 1988 water levels, and data related to water-level changes, western and southcentral Kansas: U.S. Geological Survey Open-File Report 88-342, 158 p.

Perry, C.A., Robbins, Victor, and Barnes, P.L., 1988, Factors affecting leaching in agricultural areas and an assessment of agricultural chemicals in the ground water of Kansas: U.S. Geological Survey WaterResources Investigations Report 88-4104, 55 p.

Pope, L.M., Arruda, J.A., and Fromm, C.H., 1988, Relation of trihalomethane-formation potential to water-quality and physical characteristics of small water-supply lakes, eastern Kansas: U.S. Geological Survey Water-Resources Investigations Report 88-4161, $46 \mathrm{p}$.

Pope, L.M., Jennings, M.E., and Thibodeaux, K.G., 1988, Instrumentation for a dry-pond detention study, in Proceedings of 1988 National Conference on Hydraulic Engineering: American Society of Civil Engineers, Colorado Springs, Colo., August 8-12, 1988, p. 84-89.

Rosenshein, J.S., 1988, Region 18, Alluvial valleys, in Back, William, Rosenshein, J.S., and Seaber, P.R., eds., Hydrogeology: Boulder, Colo., Geological Survey of America, The Geology of North America, v. 0-2, p. $165-175$.

Rutledge, A.T., 1988, An axisymetric model to simulate drawdown within and around pumping well [abs.], in Program of International Conference on Advances in Ground-Water Hydrology: American Institute of Hydrology, Tampa, Fla., November 16-19, 1988, p. 15.

Spruill, T.B., 1988, Use of total organic carbon as an indicator of contamination from an oil refinery, southcentral Kansas: Ground Water Monitoring Review, Summer 1988, p. 76-82.

Stullken, L.E., 1988a, Hydrologic maps of the High Plains aquifer, southwestern Kansas, January 1986: U.S. Geological Survey Water-Resources Investigations Report 88-4039, 4 sheets, scale 1:250,000.

$1988 b$, Summary of water data for the Janzen recharge investigation, Scott County, Kansas, 1980-86: U.S. Geological Survey Open-File Report 88-83, 38 p.

Thurman, E.M., Squillace, P.J., Strzepek, K.M., and Garcia, L., 1988, Intelligent data analyzer-Herbicide transport in the Cedar River, Iowa, in Preprints of Papers presented at the 196th ACS National Meeting: American Chemical Society, Los Angeles, Calif., September 25-30, 1988, v. 28, no. 2, p. 13-15.

Weeks, J.B., Gutentag, E.D., Heimes, F.J., and Luckey, R.R., 1988, Summary of the High Plains Regional aquifer-system analysis in parts of Colorado, Kansas, Nebraska, New Mexico, Oklahoma, South Dakota, Texas, and Wyoming: U.S. Geological Survey Professional Paper 1400-A, $30 \mathrm{p}$.
Bevans, H.E., 1989a, Interior province-Western region, in Britton, L.J., Anderson, C.L., Goolsby, D.A., and Van Haveren, B.P., eds., Summary of the U.S. Geological Survey and U.S. Bureau of Land Management National Coal-Hydrology Program, 1974-84: U.S. Geological Survey Professional Paper 1464, p. 53-61.

1989b, Water resources of Sedgwick County, Kansas: U.S. Geological Survey Water-Resources Investigations Report 88-4225, 119 p.

Combs, L.J., compiler, 1989, Water-resources activities of the U.S. Geological Survey in Kansas-Fiscal years 1987 and 1988: U.S. Geological Survey Open-File Report 89-592, 97 p.

Geiger, C.O., Lacock, D.L., Schneider, D.R., Carlson, M.D., and Merry, C.E., 1989, Water resources data, Kansas, water year 1988: U.S. Geological Survey Water-Data Report KS-88-1, 490 p.

Hedman, E.R., and Engel, G.B., 1989, Flow characteristics for selected streams in the Great Plains subregion of the Central Midwest aquifer system and selected adjacent areas-Kansas and Nebraska, and parts of Colorado, Iowa, Missouri, New Mexico, Oklahoma, South Dakota, Texas, and Wyoming: U.S. Geological Survey Hydrologic Investigations Atlas HA-708, 3 sheets, scale 1:1,000,000.

Helgesen, J.O., and Hansen, C.V., 1989, Description of data files compiled for the Central Midwest regional aquifer-system analysis: U.S. Geological Survey Open-File Report 89-42, $37 \mathrm{p}$.

Helgesen, J.O., and Leonard, R.B., 1989, Geohydrology of the Great Plains aquifer system, central United States, in Swain, L.A., and Johnson, A.I., eds., Regional aquifer systems of the United States-Aquifers of the midwestern area: American Water Resources Association, AWRA Monograph Series No. 13, p. 179-190.

Helgesen, J.O., and Rutledge, A.T., 1989, Relations between land use and water quality in the High Plains aquifer of south-central Kansas, in Mallard, G.E., and Ragone, S.E., eds., U.S. Geological Survey Toxic Substances Hydrology Program--Proceedings of the Technical Meeting, Phoenix, Ariz., September 26-30, 1988: U.S. Geological Survey Water-Resources Investigations Report $88-4220$, p. 437-443.

Imes, J.L., 1989a, Geohydrology and hydrochemistry of the Ozark Plateaus aquifer system, in Swain, L.A., and Johnson, A.I., eds., Regional aquifer systems of the United States, Aquifers of the midwestern area: American Water Resources Association Monograph Series 13, p. 165-178. 
$1989 \mathrm{~b}$, Major geohydrologic units in and adjacent to the Ozark Plateaus Province, Missouri, Arkansas, Kansas, and Oklahoma: U.S. Geological Survey Hydrologic Investigations Atlas HA-711-A, 1 sheet, scale 1:750,000.

1989c, Major geohydrologic units in and adjacent to the Ozark Plateaus Province, Missouri, Arkansas, Kansas, and Oklahoma-Basement confining unit: U.S. Geological Survey Hydrologic Investigations Atlas HA-711-B, 1 sheet, scale 1:750,000.

Jorgensen, D.G., 1989, Paleohydrology of the Anadarko Basin, central United States, in Johnson, K.S., ed., Anadarko Basin Symposium, 1988: Oklahoma Geological Survey Circular 90, p. 176-193.

Jorgensen, D.G., Signor, D.C., and Imes, J.L., 1989a, Accounting for intracell flow in models with emphasis on water table recharge and stream-aquifer interaction-1. Problems and concepts: Water Resources Research, v. 25, no. 4, April 1989, p. 669-676.

1989b, Accounting for intracell flow in models with emphasis on water table recharge and stream-aquifer interaction-2. A procedure: Water Resources Research, v. 25, no. 4, April 1989, p. 677-684.

Meyer, M.T., Thurman, E.M., and Bannister, Robert, 1989, Concentrating suspended sediment for organic analysis, in Pederson, G.L., and Smith, M.M., compilers, U.S. Geological Survey Second National Symposium on Water Quality-Abstracts of the Technical Sessions, Orlando, Fla., November 12-17, 1989: U.S. Geological Survey Open-File Report 89-409, p. 61.

Myers, N.C., and Bigsby, P.R., 1989, Hydrogeology and ground-water-quality conditions at the Geary County Landfill, northeast Kansas, 1988: U.S. Geological Survey Water-Resources Investigations Report 89-4114, $41 \mathrm{p}$.

Perry, C.A., 1989, A solar chronometer for climate-Astronomical and geophysical evidence: Lawrence, University of Kansas, Ph.D. dissertation, $314 \mathrm{p}$.

Perry, C.A., and Thurman, E.M., 1989, Experimental surface-water sampling device for agricultural field-runoff investigations, in Pederson, G.L., and Smith, M.M., compilers, U.S. Geological Survey Second National Symposium on Water Quality-Abstracts of the Technical Sessions, Orlando, Fla., November 12-17, 1989: U.S. Geological Survey Open-File Report 89-409, p. 72.

Pope, L.M., and Hess, L.G., 1989, Load-detention efficiencies in a dry-pond basin, in Roesner, L.A., Urbonas, Ben, and Sonnen, M.B., eds., Design of urban runoff quality controls: Proceedings of Engineering Foundation Conference on Current
Practice and Design Criteria for Urban Quality Control, Potosi, Mo., July 10-15, 1988, p. 258-267.

Rutledge, A.T., and Helgesen, J.O., 1989a, Transport of chloride and atrazine through the unsaturated zone beneath two irrigated fields in south-central Kansas, in Pederson, G.L., and Smith, M.M., compilers, U.S. Geological Survey Second National Symposium on Water Quality_Abstracts of the Technical Sessions, Orlando, Fla., November 12-17, 1989: U.S. Geological Survey Open-File Report 88-409, p. 81.

$1989 \mathrm{~b}$, Use of a simplified transport model for pesticides in the unsaturated zone, in Mallard, G.E., and Ragone, S.E., eds., U.S. Geological Survey Toxic Substances Hydrology Program-Proceedings of the Technical Meeting, Phoenix, Ariz., September 26-30, 1988: U.S. Geological Survey Water-Resources Investigations Report 88-4220, p. 523-530.

Signor, D.C., and Imes, J.L., 1989, Geohydrology of regional aquifer systems in Cretaceous and older rocks underlying the central United States, in Swain, L.A., and Johnson, A.I., eds., Regional aquifer systems of the United States-Aquifers of the midwestern area: American Water Resources Association, AWRA Monograph Series No. 13, p. 149-163.

Spruill, T.B., 1989, Transport of organic contaminants in ground water beneath an abandoned oil refinery, in Pederson, G.L., and Smith, M.M., compilers, U.S. Geological Survey Second National Symposium on Water Quality-Abstracts of the Technical Sessions, Orlando, Fla., November 12-17, 1989: U.S. Geological Survey Open-File Report 89-409, p. 95.

Townsend, Margaret, Shaukat, Nadeem, Healey, John, and McClain, Tom, 1989, Kansas water levels and data related to water-level changes: Kansas Geological Survey Ground-Water Series 10, 127 p.

1990

Adams, C.D., Randtke, C.D., Thurman, E.M., and Hulsey, R.A., 1990, Atrazine and its degradation products in soil and ground water, and the effectiveness of water-treatment processes for their removal: Proceedings from the 40th Annual University of Kansas Environmental Engineering Conference, February 7, 1990, Lawrence, Kans.: Lawrence, University of Kansas, Department of Environmental Engineering, $24 \mathrm{p}$.

Baker, C.H., Jr., and Kenny, J.F., 1990, Kansas water supply and use, in Carr, Jerry, Chase, E.B., Paulson, R.W., and Moody, D.W., compilers, National water summary 1987-Water supply and use: U.S. Geological Survey Water-Supply Paper 2350, p. 259-266. 
Barnes, Philip, and Perry, C.A., 1990, Herbicide transport in runoff from agricultural fields in Kansas: Proceedings of 7th Annual Water and the Future of Kansas Conference, Manhattan, Kans., March 7-8, 1990 , p. 23-24.

Brown, D.E., Meyer, M.T., Pomes, M.L., Thurman, E.M., and Goolsby, D.A., 1990, Temporal variations of triazine and chloroacetanilide herbicide concentrations in selected streams in the midwestern United States, in Abstracts for the AGU Fall Meeting, December 3-7, 1990, San Francisco, Calif.: EOS, Transactions of the American Geophysical Union, v. 71 , no. 43 , October 23,1990 , p. 1331.

Dugan, J.T., Schild, D.E., and Kastner, W.M., 1990, Water-level changes in the High Plains aquifer underlying parts of South Dakota, Wyoming, Nebraska, Colorado, Kansas, New Mexico, Oklahoma, and Texas-Predevelopment through nonirrigation season 1988-89: U.S. Geological Survey Water-Resources Investigations Report 90-4153, 29 p.

Falwell, Ronald, Bigsby, P.R., and Myers, N.C., 1990, Hydrogeology and ground-water-quality conditions at the Linn County Landfill, eastern Kansas, 1988-89: U.S. Geological Survey Water-Resources Investigations Report 90-4117, 48 p.

Geiger, C.O., Lacock, D.L., Schneider, D.R., Carlson, M.D., and Merry, C.E., 1990, Water resources data, Kansas, water year 1989: U.S. Geological Survey Water-Data Report KS-89-1, 457 p.

Goolsby, D.A., and Thurman, E.M., 1990, Pesticides in streams in the upper midwestern United States: Proceedings of 7 th Annual Water and the Future of Kansas Conference, Manhattan, Kans., March 7-8, 1990, p. 27-28.

Goolsby, D.A., Thurman, E.M., Clark, M.L., and Pomes, M.L., 1990, Immunoassay as a screening tool for triazine herbicides in streams-Comparison with gas chromatographic/mass spectrometric methods, in Vanderlaan, Martin, Stanker, L.H., Watkins, B.E., and Roberts, D.W., eds., Immunoassays for trace chemical analysis: American Chemical Society Symposium Series 451, chap. 8, p. 86-99.

Goolsby, D.A., Thurman, E.M., and Kolpin, D.W., 1990, Geographic and temporal distribution of herbicides in surface waters of the upper midwestern United States, 1989-90: U.S. Geological Survey Water-Resources Investigations Report 91-4034, p. 183-188.

Helgesen, J.O., 1990, Effects of agricultural and petroleum-production land use on water quality in the High Plains aquifer, south-central Kansas [abs.]: Ground Water, v. 28 , no. 5 , p. 795.

Helgesen, J.O., and Perry, C.A., 1990, Occurrence of pesticides in Kansas ground water [abs.]: Proceedings of 7 th Annual Water and the Future of Kansas Conference, Manhattan, Kans., March 7-8, 1990 , p. 22.

Imes, J.L., 1990a, Major geohydrologic units in and adjacent to the Ozark Plateaus Province, Missouri, Arkansas, Kansas, and Oklahoma-Ozark aquifer: U.S. Geological Survey Hydrologic Investigations Atlas HA-711-E, 3 sheets, scale 1:750,000.

1990b, Major geohydrologic units in and adjacent to the Ozark Plateaus Province, Missouri, Arkansas, Kansas, and Oklahoma-Ozark confining unit: U.S. Geological Survey Hydrologic Investigations Atlas HA-711-F, 3 sheets, scale 1:750,000.

1990c, Major geohydrologic units in and adjacent to the Ozark Plateaus Province, Missouri, Arkansas, Kansas, and Oklahoma-Springfield Plateau aquifer: U.S. Geological Survey Hydrologic Investigations Atlas HA-711-G, 3 sheets, scale 1:750,000.

1990d, Major geohydrologic units in and adjacent to the Ozark Plateaus Province, Missouri, Arkansas, Kansas, and Oklahoma-St. Francois aquifer: U.S. Geological Survey Hydrologic Investigations Atlas HA-711-C, 2 sheets, scale 1:750,000.

1990 , Major geohydrologic units in and adjacent to the Ozark Plateaus Province, Missouri, Arkansas, Kansas, and Oklahoma-St. Francois confining layer: U.S. Geological Survey Hydrologic Investigations Atlas HA-711-D, 3 sheets, scale 1:750,000.

1990f, Major geohydrologic units in and adjacent to the Ozark Plateaus Province, Missouri, Arkansas, Kansas, and Oklahoma-Western Interior Plains confining system: U.S. Geological Survey Hydrologic Investigations Atlas $\mathrm{HA}-711-\mathrm{H}, 3$ sheets, scale 1:750,000.

Imes, J.L., and Davis, J.V., 1990a, Water type and concentration of dissolved solids, chloride, and sulfate in ground water from the Spring field Plateau aquifer in Missouri, Arkansas, Kansas, and Oklahoma:

U.S. Geological Survey Hydrologic Investigations Atlas HA-711-L, 2 sheets, scale 1:750,000.

$1990 \mathrm{~b}$, Water type and concentration of dissolved solids, chloride, and sulfate in water from the St. Francois aquifer in Missouri, Arkansas, Kansas, and Oklahoma: U.S. Geological Survey Hydrologic Investigations Atlas $\mathrm{HA}-711-\mathrm{J}, 1$ sheet, scale $1: 750,000$.

Mills, M.S., Thurman, E.M., and Wing, R.E., 1990, Dissipation of starch-encapsulated herbicides-A field comparison with powdered herbicides, in Abstract for the AGU Fall Meeting, December 3-7, 1990, San Francisco, Calif.: EOS, Transactions of the American Geophysical Union, v. 71, no. 43, October 23, 1990 , p. 1331-1332. 
Myers, N.C., and Bigsby, P.R., 1990, Hydrogeology and ground-water-quality conditions at the Emporia-Lyon County Landfill, eastern Kansas, 1988: U.S. Geological Survey Water-Resources Investigations Report 90-4043, $42 \mathrm{p}$.

Perry, C.A., 1990a, A solar-luminosity model and climate, in Schatten, K.H., and Arking, Albert, eds., Climate impact of solar variability: National Aeronautics and Space Administration, NASA Conference Publication 3086, p. 181-188.

$1990 \mathrm{~b}$, Source, extent, and degradation of herbicides in a shallow aquifer near Hesston, Kansas: U.S. Geological Survey Water-Resources Investigations Report 90-4019, 24 p.

1990c, Speculation on a solar chronometer for climate, in Schatten, K.H., and Arking, Albert, eds., Climate impact of solar variability: National Aeronautics and Space Administration, NASA Conference Publication 3086, p. 357-364.

Perry, C.A., and Barnes, P.L., 1990, A comparison of concentrations and mass of herbicides in runoff from test plots using conventional and minimum-tillage practices, Kansas River Valley, in Abstracts of the AGU Fall Meeting, December 3-7, 1990, San Francisco, Calif.: EOS, Transactions of the American Geophysical Union, v. 71, no. 43, October 23, 1990, p. 1331.

Pomes, M.L., and Thurman, E.M., 1990, Comparison of microtitre-plate immunoassay (ELISA) and gas chromatography/mass spectrometry (GC/MS) for analysis of herbicides in stormflow samples, in Abstracts of AGU Fall Meeting, December 3-7, 1990, San Francisco, Calif.: EOS, Transactions of the American Geophysical Union, v. 71, no. 43, October 23, 1990, p. 1331.

Rutledge, A.T., and Helgesen, J.O., 1990, Characterization of ground-water flow and chemical transport beneath two irrigated fields in south-central Kansas, 1988: U.S. Geological Survey Water-Resources Investigations Report 90-4065, $37 \mathrm{p}$.

Spruill, T.B., 1990a, Monitoring regional ground-water quality - Statistical considerations and description of a monitoring network in Kansas: U.S. Geological Survey Water-Resources Investigations Report 90-4159, 41 p.

$1990 \mathrm{~b}$, Preliminary evaluation of the effects of an abandoned oil refinery on chemical quality of water in the Arkansas River Valley, Arkansas City, Kansas, 1985-86: U.S. Geological Survey Water-Resources Investigations Report 89-4190, $53 \mathrm{p}$.

Spruill, T.B., and Candela, Lucila, 1990, Two approaches to design of monitoring networks: Ground Water, v. 28 , no. 3 , p. $430-442$.
Stamer, J.K., Pope, L.M., and Zelt, R.B., 1990, Occurrence and distribution of pesticides in the lower Kansas River Basin in Kansas and Nebraska: Proceedings of 7th Annual Water and the Future of Kansas Conference, Manhattan, Kans., March 7-8, 1990, p. 25-26.

Stamer, J.K., and Zelt, R.B., 1990, Occurrence and distribution of pesticides in the inflows and outflows of reservoirs in northeast Kansas: Kansas Academy of Science, Abstracts, v. 9, p. 60.

Tanner, D.Q., Sanzolone, R.F., and Zelt, R.B., 1990, Surface-water-quality assessment of the lower Kansas River Basin, Kansas and Nebraska - Concentrations of major metals and trace elements in streambed sediments, 1987: U.S. Geological Survey Open-File Report 90-581, 73 p.

Thurman, E.M., Meyer, M.T., Pomes, M.L., Mills, M.S., and Brown, D.E., 1990, Enzyme-linked immunosorbent assay compared with gas chromatography/ mass spectrometry for the determination of triazine herbicides in water, in Abstracts of the AGU Fall Meeting, December 3-7, 1990, San Francisco, Calif.: EOS, Transactions of the American Geophysical Union, v. 71, no. 43, p. 1330.

Thurman, E.M., Meyer, Michael, Pomes, Michael, Perry, C.A., and Schwab, A.P., 1990, Enzyme-linked immunosorbent assay compared with gas chromatography/mass spectrometry for the determination of triazine herbicides in water: Analytical Chemistry, v. 62 , no. 18 , September 15,1990 , p. 2043-2048.

Wolf, R.J., Hansen, C.V., McGovern, H.E., and Spinazola, J.M., 1990, Geohydrologic systems in Kansas with emphasis on systems in upper Cambrian through lower Cretaceous rocks: U.S. Geological Survey Hydrologic Investigations Atlas HA-722-A, 2 sheets, scales $1: 1,500,000$ and 1:2,000,000.

1991

Adams, C.D., 1991, Ozonation of atrazine-A kinetic model and byproduct formation in natural waters: Lawrence, University of Kansas, Ph.D. dissertation, $242 \mathrm{p}$.

Adams, C.D., Thurman, E.M., and Hulsey, R.A., 1991, Formation and transport of deethylatrazine in the soil and vadose zone: Journal of Environmental Quality, v. 20, no. 3, July-September 1991, p. 540-547.

Buddemeier, R.W., Shamsnia, Saeed, Woods, John, and McClain, T.J., 1991, January 1990 Kansas water levels and data related to water-level changes: Kansas Geological Survey Open-File Report 91-12, 129 p. 
Clement, R.W., 1991, Kansas floods and droughts, in Paulson, R.W., Chase, E.B., Roberts, R.S., and Moody, D.W., compilers, 1991, National water summary 1988-89- Hydrologic events and floods and droughts: U.S. Geological Survey Water-Supply Paper 2375, p. 287-294.

Geiger, C.O., Lacock, D.L., Schneider, D.R., Carlson, M.D., and Pabst, B.J., 1991, Water resources data, Kansas, water year 1990, U.S. Geological Survey Water-Data Report KS-90-1, 370 p.

Gillespie, J.B., Hargadine, G.D., Myers, N.C., and Hargadine, D.A., 1991, Geohydrologic data for the South Fork Ninnescah River Valley and adjacent plains in Pratt and Kingman Counties, south-central Kansas: U.S. Geological Survey Open-File Report 91-186, $55 \mathrm{p}$.

Goolsby, D.A., Thurman, E.M., and Kolpin, D.W., 1991, Herbicides in streams-Midwestern United States: Irrigation and Drainage, Proceedings of 1991 National Conference, American Society of Civil Engineers, July 22-26, 1991, Honolulu, Hawaii, p. 17-23.

Hansen, C.V., 1991a, Description and evaluation of selected methods used to delineate wellhead-protection areas around public-supply wells near Mt. Hope, Kansas: U.S. Geological Survey Water-Resources Investigations Report 90-4102, $39 \mathrm{p}$.

1991b, Estimates of freshwater storage and potential natural recharge for principal aquifers in Kansas: U.S. Geological Survey Water-Resources Investigations Report 87-4230, $100 \mathrm{p}$.

Helgesen, J.O., 1991, Effects of land use on ground-water quality, south-central Kansas [abs.]: Proceedings of 8th Annual Water and the Future of Kansas-Water in Conflict, Manhattan, Kans., March 4-5, 1991, p. 40.

Helgesen, J.O., Stullken, L.E., and Rutledge, A.T., 1991a, Overview of nonpoint-source contamination of the High Plains aquifer in south-central Kansas, in Mallard, G.E., and Aronson, D.A., compilers, Abstracts of the Technical Meeting, U.S. Geological Survey Toxic Substances Hydrology Program, Monterey, Calif., March 1I-15, 199I: U.S. Geological Survey Open-File Report 91-88, p. 46.

$1991 \mathrm{~b}$, Overview of nonpoint-source contamination of the High Plains aquifer in south-central Kansas, in Mallard, G.E., and Aronson, D.A., eds., U.S. Geological Survey Toxic Substances Hydrology Program-Proceedings of the Technical Meeting, Monterey, Calif., March 11-15, 1991: U.S. Geological Survey WaterResources Investigations Report 91-4034, p. 301-306.

Huntzinger, T.L., 1991, National water-quality assessment program-The Central Nebraska Basins: U.S. Geological Survey Open-File Report 91-97, 2 p.
Imes, J.L., and Davis, J.V., 1991, Water type and concentration of dissolved solids, chloride, and sulfate in ground water from the Ozark aquifer in Missouri, Arkansas, Kansas, and Oklahoma: U.S. Geological Survey Hydrologic Investigations Atlas HA-711-K, 4 sheets, scale 1:750,000.

Jordan, P.R., and Jennings, M.E., 1991, Quantification of floods and droughts, in Paulson, R.W., Chase, E.B., Roberts, R.S., and Moody, D.W., compilers, National water summary 1988-89-Hydrologic events and floods and droughts: U.S. Geological Survey WaterSupply Paper 2375, p. 158-161.

Jordan, P.R., and Stamer, J.K., eds., 1991, Surface-waterquality assessment of the lower Kansas River Basin, Kansas and Nebraska--Analysis of available waterquality data through 1986: U.S. Geological Survey Open-File Report 91-75, 172 p.

Juracek, K.E., 1991, Application of geographic information system technology to ground-water management in Kansas: Program of abstracts, 36th Annual Midwest Ground Water Conference, Indianapolis, Ind., October 9-11, 1991, p. 74.

Kenny, J.F., 1991, Reported water use in Kansas, 1987: U.S. Geological Survey Open-File Report 91-212, $39 \mathrm{p}$.

Mills, M.S., 1991, Field dissipation of encapsulated herbicides-Geochemistry and degradation: Lawrence, University of Kansas, master's thesis, $98 \mathrm{p}$.

Mills, M.S., Thurman, E.M., and Patel, Ragina, 1991, Isolation of polar metabolites of atrazine by mixedmode adsorption: Abstracts of papers presented at 1991 Pittsburgh Conference \& Exposition on Analytical Chemistry and Applied Spectrometry, Chicago, Ill., March 3-8, 1991, p. 982.

Mills, M.S., Thurman, E.M., Wing, R.E., and Barnes, P.L., 1991a, Dissipation of starch-encapsulated herbicides-A field comparison with powdered herbicides, in Mallard, G.E., and Aronson, D.A., compilers, Abstracts of the Technical Meeting, U.S. Geological Survey Toxic Substances Hydrology Program, Monterey, Calif., March 11-15, 1991: U.S. Geological Survey Open-File Report 91-88, p. 13.

1991b, Dissipation of starch-encapsulated herbicides - A field comparison with powdered herbicides, in Mallard, G.E., and Aronson, D.A., eds., U.S. Geological Survey Toxic Substances Hydrology Program-Proceedings of the Technical Meeting, Monterey, Calif., March 11-15, 1991: U.S. Geological Survey Water-Resources Investigations Report 91-4034, p. 203-209. 
Mueller, D.K., DeWeese, L.R., Garner, A.J., and Spruill, T.B., 1991, Reconnaissance investigation of water quality, bottom sediment, and biota associated with irrigated drainage in the Middle Arkansas River Basin, Colorado and Kansas, 1988-89: U.S. Geological Survey Water-Resources Investigations Report 91-4060, 84 p.

Pabst, B.J., 1991, Percentage change in saturated thickness of the High Plains aquifer, west-central Kansas, 1950 to average 1988-90: U.S. Geological Survey WaterResources Investigations Report 91-4008, 1 sheet, scale 1:125,000.

Perry, C.A., 1991a, A Pleistocene/Holocene climatic model [abs.]: Symposia, Institute for TertiaryQuaternary Studies, University of Kansas, Lawrence, Kans., February 28-March 1, 1991, unnumbered page.

1991b, A solar-luminosity/oceanic/atmospheric mechanism for regional climate [abs.]: National Science Foundation, Workshop on Solar-Terrestrial Impacts on Global Change, Boulder, Colo., May 8-10, 1991, unnumbered page.

1991c, Annual precipitation estimates -1 to 4 years in advance [abs.], in Program of Federal Forecasters Conference/1991, Washington, D.C., September 12, 1991: U.S. Department of Agriculture, p. 13.

1991d, Future water availability [abs.]: Proceedings of 8th Annual Water and the Future of Kansas-Water in Conflict, Manhattan, Kans., March 4-5, 1991, p. 42.

1991e, Observed and simulated distribution of selected herbicides in silty loam, sandy loam, and clay soil profiles near Topeka, Kansas, 1986-88: U.S. Geological Survey Water-Resources Investigations Report 91-4017, 61 p.

1991f, Recent precipitation patterns in the United States as related to solar irradiance variations: AGU Program and Abstracts, 1991 Fall Meeting, December 9-13, 1991, p. 69.

$1991 \mathrm{~g}$, Some guidelines for onsite studies of pesticide leaching in the unsaturated and saturated zones: U.S. Geological Survey Water-Resources Investigations Report 91-4075, 38 p.

Perry, C.A., and Anderson, M.R., 1991, Statistical comparison of selected chemical constituents in water from chemigation and conventional irrigation wells in Kansas, 1987: U.S. Geological Survey WaterResources Investigations Report 91-4049, 1 sheet.

Pomes, M.L., and Thurman, E.M., 1991, Comparison of microtitre-plate immunoassay (ELISA) and gas chromatography/mass spectrometry (GC/MS) for analysis of herbicides in storm runoff samples [abs.]: Proceedings of 8th Annual Water and the Future of Kansas-Water in Conflict, March 4-5, 1991, p. 43.
Pomes, M.L., Thurman, E.M., and Goolsby, D.A., 1991a, Comparison of microtitre-plate, enzyme-linked immunosorbent assay (ELISA) and gas chromatography/mass spectrometry (GC/MS) for analysis of herbicides in storm-runoff samples, in Mallard, G.E., and Aronson, D.A., compilers, Abstracts of the Technical Meeting, U.S. Geological Survey Toxic Substances Hydrology Program, Monterey, Calif., March 11-15, 1991: U.S. Geological Survey OpenFile Report 91-88, p. 108.

1991b, Comparison of microtitre-plate, enzymelinked immunosorbent assay (ELISA) and gas chromatography/mass spectrometry (GC/MS) for analysis of herbicides in storm-runoff samples, in Mallard, G.E., and Aronson, D.A., eds., U.S. Geological Survey Toxic Substances Hydrology Program-Proceedings of the Technical Meeting, Monterey, Calif., March 11-15, 1991: U.S. Geological Survey Water-Resources Investigations

Report 91-4034, p. 572-575.

Pomes, M.L., Thurman, E.M., and Tate, C.M., 1991, Variation of dissolved-organic-carbon concentrations in soil waters from a tall-grass prairie and galley-forest watershed, northeast Kansas: AGU Program and Abstracts, 1991 Fall Meeting, December 9-13, 1991, p. 205-206.

Rutledge, A.T., 1991, An axisymmetric finite-difference flow model to simulate drawdown in and around a pumped well: U.S. Geological Survey WaterResources Investigations Report 90-4098, 33 p.

Rutledge, A.T., and Helgesen, J.O., 1991, Steady-state unsaturated-zone model to simulate pesticide transport: U.S. Geological Survey Water-Resources Investigations Report 90-4164, 13 p.

Stamer, J.K., 1991, An investigation summary concerning pesticides in lower Kansas River Basin in Kansas and Nebraska [abs.]: Proceedings of 8th Annual Water and the Future of Kansas--Water in Conflict, March 4-5, 1991, p. 45-46.

Stamer, J.K., and Zelt, R.B., 1991, Areal and temporal distribution of nitrogen-containing herbicides in surface water in the lower Kansas River Basin, Kansas and Nebraska: American Water Resources Association, 27th Annual Conference and Symposium, New Orleans, La., September 8-13, 1991, p. 349-350.

Thurman, E.M., Goolsby, D.A., Meyer, M.T., and Kolpin, D.W., 1991, Herbicides in surface waters of the midwestern United States-The effect of spring flush: Environmental Science and Technology, October 1991, v. 25, p. 1794-1796. 
Thurman, E.M., Meyer, Michael, and Adams, C.D., 1991a, Analysis of atrazine metabolites by enzymelinked immunosorbent assay and gas chromatography/ mass spectrometry, in Mallard, G.E., and Aronson, D.A., compilers, Abstracts of the Technical Meeting, U.S. Geological Survey Toxic Substances Hydrology Program, Monterey, Calif., March 11-15, 1991: U.S. Geological Survey Open-File Report 91-88, p. 107.

1991b, Analysis of atrazine metabolites by enzymelinked immunosorbent assay and gas chromatography/ mass spectrometry, in Mallard, G.E., and Aronson, D.A., eds., U.S. Geological Survey Toxic Substances Hydrology Program-Proceedings of the Technical Meeting, Monterey, Calif., March 11-15, 1991: U.S. Geological Survey Water-Resources Investigations Report 91-4034, p. 568-571.

Thurman, E.M., and Mills, M.S., 1991, Herbicide metabolites as indicators of surface and ground-water interaction: AGU Program and Abstracts, 1991 Fall Meeting, December 9-13, 1991, p. 168.

Zelt, R.B., 1991, GIS technology used to manage and analyze hydrologic information: GIS World, August 1991, p. 70-73.

\section{2}

Combs, L.J., and Powell, K.A., compilers, 1992, Waterresources activities of the U.S. Geological Survey in Kansas-Fiscal years 1989, 1990, and 1991: U.S. Geological Survey Open-File Report 92-90, 130 p.

Geiger, C.O., Lacock, D.L., Schneider, D.R., Carlson, M.D., and Pabst, B.J., 1992, Water resources data, Kansas, water year 1991: U.S. Geological Survey Water-Data Report KS-91-1, 358 p.

Hansen, C.V., Underwood, E.J., Wolf, R.J., and Spinazola, J.M., 1992, Geohydrologic systems in Kansas-Physical framework of the upper aquifer unit of the Western Interior Plains aquifer system: U.S. Geological Survey Hydrologic Investigations Atlas HA-722-D, 2 sheets, scales 1:1,000,000 and $1: 3,000,000$.

Hansen, C.V., Wolf, R.J., and Spinazola, J.M., 1992, Geohydrologic systems in Kansas - Physical framework of the confining unit in the Western Interior Plains aquifer system: U.S. Geological Survey Hydrologic Investigations Atlas HA-722-E, 2 sheets, scales $1: 1,000,000$ and $1: 3,000,000$.

Heck, B.A., Myers, N.C., and Hargadine, D.A., 1992, Hydrogeology and ground-water-quality conditions at the Reno County Landfill, south-central Kansas, 1990-91: U.S. Geological Survey Water-Resources Investigations Report 92-4169, $56 \mathrm{p}$.
Helgesen, J.O., Stullken, L.E., and Rutledge, A.T., 1992, Assessment of nonpoint-source contamination of the High Plains aquifer in south-central Kansas, 1987: U.S. Geological Survey Water-Supply Paper 2381-C, $61 \mathrm{p}$.

Juracek, K.E., 1992a, Determining water availability in Kansas: Geo Info Systems, v. 2, no. 8, p. 52-57.

$1992 \mathrm{~b}$, The utility of geographic information system technology for addressing the effect of agricultural pesticide use on surface-water quality: Proceedings of 9th Annual Water and the Future of Kansas Conference, Manhattan, Kans., March 4-5, 1992, p. $29-30$.

1992c, Use of a geographic information system to assist with studies of the availability and use of water in Kansas: U.S. Geological Survey Open-File Report 92-142, 14 p.

Juracek, K.E., Kenny, J.F., and Perry, C.A., 1992, Herbicides, water quality and you: U.S. Geological Survey Open-File Report 92-127, video.

Mills, M.S., and Thurman, E.M., 1992, Mixed-mode isolation of triazine metabolites in soil and aquifer sediments using automated solid-phase extraction: Analytical Chemistry, v. 64, p. 1985-1990.

Myers, N.C., 1992, Chloride distribution in the alluvial aquifer adjacent to the Arkansas River between Hutchinson and Wichita, south-central Kansas: Kansas Academy of Science, Abstracts of Papers Presented at 124th Annual Meeting, Hutchinson, Kans., March 26-27, 1992, v. 11, p. 33.

Perry, C.A., 1992a, A correlation between precipitation in the western United States and solar irradiance variations: American Water Resources Association, Proceedings of 28th Annual Conference \& Symposium on Managing Water Resources During Global Change, Reno, Nev., November 1-5, 1992, p. 721-729.

1992b, Annual precipitation estimates -1 to 4 years in advance, in Papers and Proceedings of Federal Forecasters Conference/1991: Washington, D.C., September 12, 1991, p. 134-135.

1992c, The future of rainfall in Kansas[ abs.]: Proceedings of 9th Annual Water and the Future of Kansas Conference, Manhattan, Kans., March 4-5, 1992, p. 36.

Shamet, K.A., 1992, Surfactants in a natural foam-Characterization and role in enhanced degradation of herbicides: Lawrence, University of Kansas, master's thesis, $83 \mathrm{p}$.

Spinazola, J.M., Wolf, R.J., and McGovern, H.E., 1992, Geohydrologic systems in Kansas-Physical framework of the Great Plains aquifer system: U.S. Geological Survey Hydrologic Investigations Atlas HA-722-B, 2 sheets, scales 1:1,000,000 and $1: 2,000,000$. 
Squillace, P.J., and Thurman, E.M., 1992, Herbicide transport in rivers-Importance of hydrology and geochemistry in nonpoint-source contamination: Environmental Science and Technology, v. 26, no. 3, p. 538-545.

Stamer, J.K., 1992, Distribution of atrazine in surface water, lower Kansas River Basin, Kansas and Nebraska [abs.]: Proceedings of North Central Weed Science Society, v. 47, p. 148.

Stamer, J.K., and Zelt, R.B., 1992, Distribution of atrazine and similar nitrogen-containing herbicides, lower Kansas River Basin: U.S Geological Survey Director's Yearbook 1991, p. 76-79.

Thurman, E.M., Goolsby, D.A., Meyer, M.T., and Kolpin, D.W., 1992, A reconnaissance study of herbicides and their metabolites in surface water of the midwestern United States using immunoassay and gas chromatography/mass spectrometry: Environmental Science and Technology, v. 26, no. 12, p. 2440-2447.

Trombley, T.J., and Kenny, J.F., 1992, Water resources on and near Indian lands in northeastern Kansas and southeastern Nebraska-Study description: U.S. Geological Survey Open-File Report 91-468, 19 p.

Wolf, R.J., McGovern, H.E., and Spinazola, J.M., 1992, Geohydrologic systems in Kansas-Physical framework of the Western Interior Plains confining system: U.S. Geological Survey Hydrologic Investigations Atlas HA-722-C, 2 sheets, scales 1:1,000,000 and $1: 3,000,000$.

\section{3}

Aga, D.S., and Thurman, E.M., 1993a, Chromatographic application of solid-phase extraction in developing immunoassay methods for herbicides and their metabolites-An example for alachlor and alachlorethanesulfonic acid [abs.], in Programs and proceedings of symposium on agricultural nonpoint sources of contaminants-Focus on herbicides, Lawrence, Kans., September 28-29, 1993: U.S. Environmental Protection Agency, Region VII, and U.S. Geological Survey, p. 38.

1993b, Coupling solid-phase extraction (SPE) and enzyme-linked immunosorbent assay (ELISA) for ultratrace analysis of herbicides in pristine water: Analytical Chemistry, v. 65, p. 2894-2898.

Aga, D.S., Thurman, E.M., and Pomes, M.L., 1993, Measurement of concentrations of alachlor and its ethanesulfonic acid metabolite in water by solid-phase extraction and enzyme-linked immunosorbent assay, in Morganwalp, D.W., and Aronson, D.A., compilers, U.S. Geological Survey Toxic Substances Hydrology Program-Abstracts of the Technical Meeting,
Colorado Springs, Colo., September 20-24, 1993:

U.S. Geological Survey Open-File Report 93-454, p. 80 .

Bevans, H.E., Fromm, C.H., and Watkins, S.A., 1993, The occurrence and transport of agricultural pesticides in the Tuttle Creek Lake-stream system, Kansas and Nebraska: U.S. Geological Survey Open-File Report 93-87, 44 p.

Combs, L.J., Hansen, C.V., and Wolf, R.J., 1993, Geohydrologic systems in Kansas-Geohydrology of the lower aquifer unit in the Western Interior Plains aquifer system: U.S. Geological Survey Hydrologic Investigations Atlas HA-722-I, 3 sheets, scale 1:1,500,000.

Cromwell, A.E., and Thurman, E.M., 1993a, Atrazine transport and degradation in a pristine watershed-The fate of atrazine deposited by precipitation, in Morganwalp, D.W., and Aronson, D.A., compilers, U.S. Geological Survey Toxic Substances Hydrology Program-Abstracts of the Technical Meeting, Colorado Springs, Colo., September 20-24, 1993: U.S. Geological Survey Open-File Report 93-454, p. 82.

$1993 \mathrm{~b}$, Herbicide transport and degradation in a pristine watershed-The fate of herbicides deposited by precipitation [abs.], in Programs and proceedings of symposium on agricultural nonpoint sources of contaminants-Focus on herbicides, Lawrence, Kans., September 28-29, 1993: U.S. Environmental Protection Agency, Region VII, and U.S. Geological Survey, p. 17.

Dankwardt, Andrea, Hock, Bertold, and Thurman, E.M., 1993, Comparison of enzyme-linked immunosorbent assay and gas chromatography/mass spectrometry for the analysis of atrazine in rainwater of Germany [abs.], in New separation and detection methods, Programme and Organisation Abstracts, New Swiss Chemical Society, Basel Switzerland, October 19-20, 1993: New Swiss Chemical Society, $2 \mathrm{p}$.

Fallon, J.D., and McChesney, J.A., 1993, Surface-waterquality assessment of the lower Kansas River Basin, Kansas and Nebraska - Project data, November 1986 through April 1990: U.S. Geological Survey OpenFile Report 93-51, 594 p.

Fallon, J.D., and Thurman, E.M., 1993a, Determining the age, transport, and three-dimensional distribution of atrazine in a reservoir by immunoassay [abs.], in Programs and proceedings of symposium on agricultural nonpoint sources of contaminants-Focus on herbicides, Lawrence, Kans., September 28-29, 1993 : U.S. Environmental Protection Agency, Region VII, and U.S. Geological Survey, p. 13. 
1993b, Determining the relative age, transport, and three-dimensional distribution of atrazine in a reservoir using immunoassay, in Morganwalp, D.W., and Aronson, D.A., compilers, U.S. Geological Survey Toxic Substances Hydrology Program-Abstracts of the Technical Meeting, Colorado Springs, Colo., September 20-24, 1993: U.S. Geological Survey Open-File Report 93-454, p. 72.

Geiger, C.O., Lacock, D.L., Schneider, D.R., Carlson, M.D., and Dague, B.J., 1993, Water resources data, Kansas, water year 1992: U.S. Geological Survey Water-Data Report KS-92-1, 500 p.

Hansen, C.V., 1993a, Description of geographic-information-system files containing water-resource-related data compiled and collected for Wyandotte County, northeastern Kansas: U.S. Geological Survey OpenFile Report 93-92, 46 p.

1993b, Description of water-resource-related data compiled for Harvey County, south-central Kansas: U.S. Geological Survey Open-File Report 93-116, 29 p.

1993c, Description of water-resource-related data compiled for Reno County, south-central Kansas: U.S. Geological Survey Open-File Report 93-99, 27 p.

Helgesen, J.O., Heck, B.A., and Hargadine, D.A., 1993, Hydrogeology and ground-water-quality conditions at the Harvey County Landfill, south-central Kansas, 1990: U.S. Geological Survey Water-Resources Investigations Report 93-4036, 44 p.

Helgesen, J.O., Leonard, R.B., and Wolf, R.J., 1993, Hydrology of the Great Plains aquifer system in Nebraska, Colorado, Kansas, and adjacent areas: U.S. Geological Survey Professional Paper 1414-E, 80 p., 10 pls.

Jorgensen, D.G., 1993, Paleohydrology of the Central United States: U.S. Geological Survey Bulletin 1989-D, 32 p.

Jorgensen, D.G., Helgesen, J.O., and Imes, J.L., 1993, Regional aquifers in Kansas, Nebraska, and parts of Arkansas, Colorado, Missouri, New Mexico, Oklahoma, South Dakota, Texas, and Wyoming--Geohydrologic framework: U.S. Geological Survey Professional Paper 1414-B, 72 p., 25 pIs.

Juracek, K.E., and Kenny, J.F., 1993a, Management and analysis of water-use data using a geographic information system: Water Resources Bulletin, v. 29, no. 6, p. 973-979.

1993b, Management and analysis of water-use data using a geographic information system, in Harlin, J.M., and Lanfear, K.J., eds., Geographic information systems and water resources: American Water Resources Association, Proceedings, p. 483-490, $627-628$.
Kenny, J.F., 1993, Kansas stream water quality, in Paulson, R.W., Chase, E.B., Williams, J.S., and Moody, D.W., compilers, National water summary 1990-91-Hydrologic events and stream water quality: U.S. Geological Survey Water-Supply Paper 2400, p. 277-284.

Kenny, J.F., Hansen, C.V., and Wolf, R.J., 1993, Geohydrologic systems in Kansas-Geohydrology of the upper aquifer unit in the Western Interior Plains aquifer system: U.S. Geological Survey Hydrologic Investigations Atlas $\mathrm{HA}-722-\mathrm{H}, 2$ sheets, scale 1:1,500,000.

Kolpin, D.W., Burkart, M.R., and Thurman, E.M., 1993, Hydrogeologic, water-quality, and land-use data for the reconnaissance of herbicides and nitrate in nearsurface aquifers of the midcontinental United States, 1991: U.S. Geological Survey Open-File Report 93-114, 61 p.

McGovern, H.E., and Wolf, R.J., 1993, Geohydrologic systems in Kansas - Geohydrology of the Great Plains aquifer system: U.S. Geological Survey Hydrologic Investigations Atlas $\mathrm{HA}-722-\mathrm{G}, 2$ sheets, scales $1: 1,000,000,1: 2,000,000$, and 1:3,000,000.

Meyer, M.T., Mills, M.S., and Thurman, E.M., 1993, Automated solid-phase extraction of herbicides from water for gas chromatographic/mass spectrometric analysis: Journal of Chromatography, v. 629, p. 55-59.

Meyer, M.T., and Thurman, E.M., 1993a, Cyanazine metabolites in surface water-The transport and degradation of labile herbicides [abs.], in Proceedings of spring meeting, American Geophysical Union, Mineralogical Society of America, and Geochemical Society, Baltimore, Md., May 24-28, 1993: EOS, Transactions of the American Geophysical Union, April 20, 1993, p. 135.

1993b, Cyanazine metabolites in surface water-The transport and degradation of labile herbicides [abs.], in Programs and proceedings of symposium on agricultural nonpoint sources of contaminants-Focus on herbicides, Lawrence, Kans., September 28-29, 1993 : U.S. Environmental Protection Agency, Region VII, and U.S. Geological Survey, p. 21.

1993c, The degradation and transport of cyanazine metabolites in surface water of the midwestern United States, in Morganwalp, D.W., and Aronson, D.A., compilers, U.S. Geological Survey Toxic Substances Hydrology Program-Abstracts of the Technical Meeting, Colorado Springs, Colo., September 20-24, 1993: U.S. Geological Survey Open-File Report 93-454, p. 87.

Mills, M.S., Thurman, E.M., and Pedersen, M.J., 1993, Application of mixed-mode, solid-phase extraction in environmental and clinical chemistry-Combining hydrogen-bonding, cation-exchange and Van der Waals interactions: Journal of Chromatography, v. 629, p. $11-21$. 
Myers, N.C., Heck, B.A., and Hargadine, D.A., 1993, Hydrogeology and ground-water-quality conditions at the Sumner County Landfill, south-central Kansas, 1989-90: U.S. Geological Survey Water-Resources Investigations Report 92-4177, $52 \mathrm{p}$.

Perry, C.A., 1993a, A mechanism for the link between solar-irradiance variations and regional precipitation, in Redmond, K.T., and Tharp, V.L., eds., Proceedings of the Ninth Annual Pacific Climate (PACLIM) Workshop, Asilomar, Calif., April 21-24, 1992: California Department of Water Resources, Interagency Ecological Studies Program, Technical Report 34, p. 97-102.

1993b, A solar-weather mechanism: World Meteorological Organization Bulletin, v. 42, no. 2, p. 123-129.

Perry, C.A., and others, 1993, Detection of fractures in Ash Meadows, southwestern Nevada by electromagnetic terrain-conductivity measurements, in Proceedings SPIE-The International Society for Optical Engineering, Ground Sensing, Orlando, Fla., April 14, 1993, v. 1941, p. 113-124.

Plummer, L.N., Michel, R.L., Thurman, E.M., and Glynn, P.D., 1993, Environmental tracers for age dating young ground water, in Alley, W.M., ed., Regional ground-water quality: New York, Van Nostrand Reinhold, p. 255-294.

Pomes, M.L., Holub, D.G., Aga, D.S., and Thurman, E.M., 1993a, Isocratic separation of alachlor ethanesulfonic acid, alachlor oxoacetic acid, and hydroxyatrazine by reversed-phase liquid chromatography, in Morganwalp, D.W., and Aronson, D.A., compilers, U.S. Geological Survey Toxic Substances Hydrology Program-Abstracts of the Technical Meeting, Colorado Springs, Colo., September 20-24, 1993: U.S. Geological Survey Open-File Report 93-454, p. 81.

1993b, Isocractic separation of alachlor ethanesulfonic acid alachlor oxacetic acid, and hydroxyatrazine by reversed-phase liquid chromatography [abs.], in Programs and proceedings of symposium on agricultural nonpoint sources of contaminants-Focus on herbicides, Lawrence, Kans., September 28-29, 1993: U.S. Environmental Protection Agency, Region VII, and U.S. Geological Survey, p. 37.

Scribner, E.A., Thurman, E.M., and Goolsby, D.A., 1993a, Reconnaissance data for selected herbicides and their metabolites in surface water of the midwestern United States-Immunoassay and gas chromatography/mass spectrometry [abs.], in Programs and proceedings of symposium on agricultural nonpoint sources of contaminants-Focus on herbicides, Lawrence, Kans., September 28-29, 1993: U.S. Environmental Protection Agency, Region VII, and U.S. Geological Survey, p. 41. 1993b, Reconnaissance data for selected herbicides and two metabolites in surface water of the midwestern United States-Chemical analysis by immunoassay and gas chromatography/mass spectrometry, in Morganwalp, D.W., and Aronson, D.A., compilers, U.S. Geological Survey Toxic Substances Hydrology Program-Abstracts of the Technical Meeting, Colorado Springs, Colo., September 20-24, 1993: U.S. Geological Survey Open-File Report 93-454, p. 84.

Scribner, E.A., Thurman, E.M., Goolsby, D.A., Meyer, M.T., Mills, M.S., and Pomes, M.L., 1993,

Reconnaissance data for selected herbicides, two atrazine metabolites, and nitrate in surface water of the midwestern United States, 1989-90: U.S. Geological Survey Open-File Report 93-457, 77 p.

Squillace, P.J., Thurman, E.M., and Furlong, E.T., 1993, Groundwater as nonpoint source of atrazine and deethylatrazine in a river during base flow conditions: Water Resources Research, v. 29, no. 6, p. 1719-1729.

Thurman, E.M., 1993a, Chemistry, degradation, and transport of triazine metabolites in surface water [abs.], in Proceedings of spring meeting, American Geophysical Union, Mineralogical Society of America, and Geochemical Society, Baltimore, Md., May 24-28, 1993: EOS, Transactions of the American Geophysical Union, April 20, 1993, p. 129.

1993b, Chemistry, degradation, and transport of triazine metabolites in surface water [abs.], in Programs and proceedings of symposium on agricultural nonpoint sources of contaminants-Focus on herbicides, Lawrence, Kans., September 28-29, 1993: U.S. Environmental Protection Agency, Region VII, and U.S. Geological Survey, p. 19.

Thurman, E.M., Mills, M.S., and Meyer, M.T., 1993, Chemistry, degradation, and transport of triazine herbicide metabolites in surface water, in Morganwalp, D.W., and Aronson, D.A., compilers, U.S. Geological Survey Toxic Substances Hydrology Program-Abstracts of the Technical Meeting, Colorado Springs, Colo., September 20-24, 1993: U.S. Geological Survey Open-File Report 93-454, p. 68.

Wolf, R.J., and Helgesen, J.O., 1993, Ground- and surface-water interaction between the Kansas River and associated alluvial aquifer, northeastern Kansas: U.S. Geological Survey Water-Resources Investigations Report 92-4137, 49 p.

Wolock, D.M., 1993a, Effects of topography and subbasin size on simulated flow pathways in Sleepers River watershed, Vermont [abs.]: EOS, Transactions of the American Geophysical Union, v. 74, no. 43, unnumbered page. 
1993b, Simulating the variable-source-area concept of streamflow generation with the watershed model TOPMODEL: U.S. Geological Survey WaterResources Investigations Report 93-4124, 33 p. 1993c, TOPMODEL, a topographic-based watershed model, in Burton, J.S., compiler, Proceedings of the federal interagency workshop on hydrologic demands for the 90's: U.S. Geological Survey Water-Resources Investigations Report 93-4018, p. 8-50-8-57.

Wolock, D.M., and McCabe, G.J., 1993, Effects of climate change on water resources in the Delaware River Basin, in Proceedings of the First National Conference on Climate Change and Water Resources Management, Albuquerque, New Mexico, November 5-7, 1991: U.S. Army Corps of Engineers, p. II-140-II-149.

Wolock, D.M., McCabe, G.J., Jr., Tasker, G.D., and Moss, M.E., 1993, Effects of climate change on water resources in the Delaware River Basin: Water Resources Bulletin, v. 29, no. 3, p. 475-486.

Zamarripa, G.T., and Perry, C.A., 1993, Multipleregression analysis of climatic factors and Kansas regional precipitation, in Abstract of Papers presented at a Joint Meeting of the Missouri and Kansas Academies of Science, Kansas City, Mo., April 23-24, 1993: Kansas Academy of Science, v. 13, p. 96.

Zimmerman, L.R., and Thurman, E.M., 1993, Trace analysis of the herbicide 2,4-D in water samples by solid-phase extraction (SPE) and enzyme-linked immunosorbent assay (ELISA) [abs.], in Abstract book of 14th annual meeting-Ecological risk assessment, lessons learned?, Houston, Tex., November 14-18, 1993: Society of Environmental Toxicology and Chemistry, p. 522.

\section{4}

Aga, D.S., Thurman, E.M., and Pomes, M.L., 1994, Determination of alachlor and its ethane-sulfonic acid metabolite in water by solid-phase extraction and enzyme-linked immunosorbent assay: Analytical Chemistry, v. 66, no. 9, May 1, 1994, p. 1495-1499.

Brewer, L.D., Trombley, T.J., and Pomes, M.J., 1994, Water resources on and near Indian lands in northeastern Kansas and southeastern Nebraska-Hydrologic data through 1990: U.S. Geological Survey Open-File Report 94-35, 424 p.

Fallon, J.D., 1994, Determining the 3-dimensional distribution, transport, and relative age of atrazine and selected metabolites in Perry Lake, Kansas: Lawrence, University of Kansas, master's thesis, 176 p.

Fan, Jian, Wolock, D.M., and Lawrence, Gregory, 1994, Using GIS to study the spatial relation between watershed topography and stream chemistry in the Neversink River Basin, New York [abs.]: EOS, Transactions of the American Geophysical Union, v. 75 , no. 16 , unnumbered page.

Geiger, C.O., Lacock, D.L., Schneider, D.R., Carlson, M.D., and Dague, B.J., 1994, Water resources data Kansas, water year 1993: U.S. Geological Survey Water-Data Report KS-93-1, 497 p.

Gillespie, J.B., and Hargadine, G.D., 1994, Geohydrology and saline ground-water discharge to the South Fork Ninnescah River in Pratt and Kingman Counties, south-central Kansas: U.S. Geological Survey WaterResources Investigations Report 93-4177, 51 p.

Hansen, C.V., Spinazola, J.M., and Wolf, R.J., 1994, Geohydrologic systems in Kansas-Physical framework of the lower aquifer unit in the Western Plains aquifer system: U.S. Geological Survey Hydrologic Investigations Atlas 722-F, 2 sheets, scales 1:1,000,000 and 1:3,000,000.

Helgesen, J.O., Stullken, L.E., and Rutledge, A.T., 1994, Assessment of nonpoint-source contamination of the High Plains aquifer in south-central Kansas, 1987: U.S. Geological Survey Water-Supply Paper 2381-C, $51 \mathrm{p}$.

Juracek, K.E., 1994a, Concentrations of triazine herbicides in the unsaturated zone in western Harvey County, Kansas, spring and fall 1992-93: U.S. Geological Survey Open-File Report 94-497, 23 p.

$\mathbf{1 9 9 4 b}$, Description and use of a geographicinformation-system-based water information management and analysis system (WIMAS): U.S. Geological Survey Open-File Report 94-46, 20 p. $1994 c$, Interactive query of State water-appropriations and water-use information: Geo Info Systems, November/December 1994, p. 44-48.

Kolpin, D.W., Burkart, M.R., and Thurman, E.M., 1994, Herbicides and nitrate in near-surface aquifers in the midcontinental United States, 1991: U.S. Geological Survey Water-Supply Paper 2413, 34 p.

Leahy, P.P., and Stamer, J.K., 1994, Herbicides in the lower Kansas River Basin--Policy relevant findings from the U.S. Geological Survey's National WaterQuality Assessment [abs.]: Program of 1994 Annual Meeting of the Geological Society of America, Seattle, Wash., October 24-27, 1994, p. A-106.

Mills, M.S., and Thurman, E.M., 1994a, Preferential dealkylation of s-triazine herbicides in the unsaturated zone: Environmental Science and Technology, v. 28, no. 4 , p. $600-605$.

$\mathbf{1 9 9 4 b}$, Reduction of nonpoint source contamination of surface water and groundwater by starch encapsulation of herbicides: Environmental Science and Technology, v. 28, no. 1, p. 73-79. 
Meyer, M.T., 1994, Geochemistry of cyanazine and its metaboliltes-Indicators of contaminant transport in surface water of the midwestern United States: Lawrence, University of Kansas, Ph.D. dissertation, $362 \mathrm{p}$.

Perry, C.A., 1994a, Effects of reservoirs on flood discharges in the Kansas and the Missouri River Basins, 1993-Floods in the upper Mississippi River Basin, 1993: U.S. Geological Survey Circular 1120-E, $20 \mathrm{p}$.

1994b, Solar-irradiance variations and regional precipitation fluctuations in the western USA: International Journal of Climatology, v. 14, November 1994, p. 969-983.

Perry, C.A., and Studley, S.E., 1994, Effect of flood control reservoirs on peak discharges along the Kansas River, 1993 [abs.]: EOS, Transactions of the American Geophysical Union, v. 74, no. 43, p. 61 .

Powell, K.A., 1994, Water-resources activities of the U.S. Geological Survey in Kansas-Fiscal years 1992 and 1993, and plans for fiscal year 1994: U.S. Geological Survey Open-File Report 94-89, 122 p.
Rasmussen, P.P., 1994, The hydrogeology and the groundwater quality conditions at the City of Olathe Landfill: Lawrence, University of Kansas, master's thesis, $90 \mathrm{p}$.

Rasmussen, P.P., Shockley, J.C., and Hargadine, D.A., 1994, Hydrogeology and water-quality conditions at the City of Olathe Landfill, east-central Kansas, 1990-93: U.S. Geological Survey Water-Resources Investigations Report 94-4166, 44 p.

Scribner, E.A., Goolsby, D.A., Thurman, E.M., Meyer, M.T., and Pomes, M.L., 1994, Concentrations of selected herbicides, two triazine metabolites, and nutrients in storm runoff from nine stream basins in the midwestern United States, 1990-92: U.S. Geological Survey Open-File Report 94-396, 144 p.

Stamer, J.K., and Zelt, R.B., 1994, Organonitrogen herbicides in the lower Kansas River Basin: American Water Works Association, v. 86, no. 1, January 1994, p. 93-104.

Wolock, D.M., and Price, C.V., 1994, Effects of digital elevation model map scale and data resolution on a topography-based watershed model: Water Resources Research, November 1994, v. 30, no. 11 , p. 3041-3052. 


\section{GEOGRAPHIC INDEX}

This index was compiled by scanning the report titles. It is intended as an aid in the initial search for a specific geographic area. This index is arranged alphabetically by geographic location. The keyword sends you from a location of interest to an author entry. Listings under each geographic location are arranged alphabetically by the author's last name and initials, followed by the year of publication. For a complete bibliographic citation, the reader should refer to "Alphabetical Listing by Author," beginning on page 3.

A

\section{Abilene}

Gillespie, J.B., and Hargadine, G.D., 1981

\section{Allen County}

Miller, D.E., 1969

\section{Arkansas}

Dugan, J.T., 1986

Hedman, E.R., and others, 1987

Imes, J.L., 1989a; 1989b; 1989c; 1990a; 1990b; 1990c; 1990d; 1990e; 1990f

Imes, J.L., and Davis, J.V., 1990a; 1990b; 1991

Jorgensen, D.G., and others, 1993

Jorgensen, D.G., and Signor, D.C., 1981

\section{Arkansas City}

Spruill, T.B., 1990b

\section{Ash Meadows [Nevada]}

Perry, C.A., and others, 1993

\section{Atchison County}

Frye, J.C., 1941

Ward, J.R., 1971; 1973

\section{B}

\section{Barber County}

Williams, C.C., and Bayne, C.K., 1946

\section{Barton County}

Latta, B.F., 1950

\section{Bonner Springs}

Dufford, A.E., 1958

\section{Brown County}

Bayne, C.K., and Schoewe, W.H., 1967

\section{C}

\section{Central Kansas}

Bayne, C.K., and others, 1971

Bayne, C.K., and Ward, J.R., 1974

Clement, R.W., and Johnson, D.G., 1982

Fader, S.W., 1975

Gillespie, J.B., and Hargadine, G.D., 1981; 1986

Gillespie, J.B., and others, 1970

\section{Central Kansaa-Continued}

Gillespie, J.B., and Slagle, S.E., 1972

Gogel, Tony, 1981a

Jordan, P.R., and others, 1964

Kansas Water Board, 1958-62

McNellis, J.M., 1973

\section{Central Nebraska Basins}

Huntzinger, T.L., 1991

\section{Central United States}

Helgesen, J.O., and Leonard, R.B., 1988; 1989

James, I.C., II, 1968

Jorgensen, D.G., 1989; 1993

Leonard, R.B., and others, 1983

Signor, D.C., and Imes, J.L., 1989

\section{Chase County}

O'Connor, H.G., 1949; 1951

\section{Cherokee County}

Pope, L.M., and Diaz, A.M., 1982

Spruill, T.B., 1984a; 1987b

\section{Chevenne County}

Keene, K.M., and others, 1969

Prescott, G.C., Jr., 1953a

\section{Clay County}

Walters, K.L., and Bayne, C.K., 1959

\section{Cloud County}

Bayne, C.K., and Walters, K.L., 1959

Fader, S.W., 1968

Fishel, V.C., 1948a

\section{Colorado}

Dugan, J.T., 1986

Dugan, J.T., and others, 1990

Feder, G.L., and Krothe, N.C., 1981

Gutentag, E.D., and others, 1984

Hedman, E.R., and Engel, G.B., 1989

Heimes, F.J., and Luckey, R.R., 1980; 1983

Helgesen, J.O., and others, 1993

Jorgensen, D.G., and others, 1993

Jorgensen, D.G., and Signor, D.C., 1981

Krothe, N.C., and others, 1982

Luckey, R.R., and others, 1988

Mueller, D.K., and others, 1991 


\section{Colorado-Continued}

Osterkamp, W.R., and others, 1981

Snipes, R.J., and others, 1974

U.S. Geological Survey, 1966a

Weeks, J.B., and others, 1988

\section{Cottonwood Falls}

Prosser, C.S., and Beede, J.W., 1904

\section{Cowley County}

Bayne, C.K., 1962

Diaz, A.M., 1962b

\section{Crawford County}

Pope, L.M., and Diaz, A.M., 1982

\section{D}

\section{Decatur County}

Hodson, W.G., 1969

Keene, K.M., and others, 1969

\section{Dickinson County}

Gutentag, E.D., and Galli-Olivier, Carlos, 1969

Latta, B.F., 1949

\section{Doniphan County}

Bayne, C.K., 1971; 1973

\section{Douglas County}

Gogel, Tony, 1981b

O'Connor, H.G., 1960

\section{Downs}

Dingman, R.J., 1969

\section{E}

\section{East-central Kansas}

Carswell, W.J., Jr., and Hart, R.J., 1985

Jordan, P.R., and Hart, R.J., 1985

Kansas Water Board, 1958-62

Rasmussen, P.P., and others, 1994

\section{Eastern Kansas}

Bevans, H.E., 1984; 1986

Clement, R.W., 1983

Falwell, Ronald, and others, 1990

Kenny, J.F., and others, 1982

Myers, N.C., and Bigsby, P.R., 1990

Pope, L.M., and others, 1985; 1988

Reed, T.B., and Burnett, R.D., 1985

\section{Edwards County}

McLaughlin, T.G., 1949

\section{Elk County}

Bayne, C.K., 1958

\section{Ellis County}

Frye, J.C., and others, 1943

Leonard, A.R., and Berry, D.W., 1961

\section{Ellsworth County}

Bayne, C.K., and others, 1971

Waterman, W.D., 1952

\section{Emporia}

Myers, N.C., and Bigsby, P.R., 1990

\section{$\mathbf{F}$}

\section{Finney County}

Dunlap, L.E., and others, 1983; 1985

Gutentag, E.D., and others, 1972

Hathaway, L.R., and others, 1977

Latta, B.F., 1944

Lindgren, R.J., 1982

Meyer, W.R., and others, 1969; 1970

\section{Ford County}

Hathaway, L.R., and others, 1978

Lobmeyer, D.H., and Weakly, E.C., 1978; 1979

Spinazola, J.M., and Dealy, M.T., 1983

Waite, H.A., 1942

\section{G}

\section{Geary County}

Latta, B.F., 1949

Myers, N.C., and Bigsby, P.R., 1989

\section{Gorham County}

Latta, B.F., 1948b

\section{Gove County}

Hodson, W.G., and Wahl, K.D., 1960

Keene, K.M., and Pabst, M.E., 1971

McClain, T.J., and others, 1975

\section{Graham County}

Prescott, G.C., Jr., 1955

Spinazola, J.M., 1981

\section{Grant County}

Fader, S.W., and others, 1964

McLaughlin, T.G., 1946

Nuzman, C.E., and Meyer, W.R., 1965

Winslow, J.D., and others, 1964; 1968

\section{Gray County}

Hathaway, L.R., and others, 1977

Latta, B.F., 1944

McGovern, H.E., and Long, W.A., 1974

\section{Great Bend}

Clement, R.W., and Johnson, D.G., 1982 


\section{Greeley County}

Prescott, G.C., Jr., and others, 1954

Slagle, S.E., and Weakly, E.C., 1976

Stullken, L.E., and others, 1974

\section{H}

\section{Hamilton County}

Dunlap, L.E., and others, 1984

Hathaway, L.R., and others, 1977

Lobmeyer, D.H., and Sauer, C.G., 1974

McLaughlin, T.G., 1943

\section{Harper County}

Bayne, C.K., 1960

\section{Harvey County}

Hansen, C.V., 1993b

Juracek, K.E., 1994a

Perry, C.A., 1984b

\section{Haskell County}

Gutentag, E.D., and Stullken, L.E., 1974

McLaughlin, T.G., 1946

Hays

Latta, B.F., $1948 b$

Hesston

Perry, C.A., $1990 \mathrm{~b}$

\section{Hodgeman County}

Lobmeyer, D.H., and Weakly, E.C., 1978; 1979

\section{Hutchinson}

Myers, N.C., 1992

Williams, C.C., 1946

\section{I}

\section{Independence}

Schrader, F.C., 1908

Schrader, F.C., and Haworth, Erasmus, 1906

Ingalls

Stramel, G.J., and others, 1958

lowa

Hedman, E.R., and Engel, G.B., 1989

Thurman, E.M., and others, 1988

\section{J}

\section{Jackson County}

Walters, K.L., 1953

\section{Jefferson County}

Winslow, J.D., 1972

\section{Jewell County}

Fader, S.W., 1968

Fishel, V.C., and Leonard, A.R., 1955

\section{Johnson County}

O'Connor, H.G., 1971; 1973

\section{Junction City}

Fader, S.W., 1974

\section{K}

\section{Kansas City}

Fader, S.W., 1974

Fishel, V.C., 1948b

Fishel, V.C., and others, 1953

Hauth, L.D., and Carswell, W.J., Jr., 1978

Hauth, L.D., and others, 1981

\section{Kearny County}

Dunlap, L.E., and others, $1983 ; 1984 ; 1985$

Gutentag, E.D., and others, 1970; 1972

Hathaway, L.R., and others, 1977

Lindgren, R.J., 1982

McLaughlin, T.G., 1943

\section{Kingman County}

Gillespie, J.B., and Hargadine, G.D., 1994

Gillespie, J.B., and others, 1991

Lane, C.W., 1960

\section{Kiowa County}

Latta, B.F., 1948a

\section{$\mathbf{L}$}

\section{Labette County}

Gogel, Tony, 1981b

Jungmann, W.L., and Williams, C.C., 1968

Prescott, G.C., Jr., 1948

Lakln

Darton, N.H., 1920

Gillespie, J.B., and others, 1977

\section{Lane County}

Gutentag, E.D., and Stullken, L.E., 1976

Prescott, G.C., Jr., 1951

Stullken, L.E., and others, 1974

\section{Lansing}

Lohman, S.W., and Mitchell, Alexander, 1940

\section{Lawrence}

Davis, S.N., and Carlson, W.A., 1952

Dufford, A.E., 1958

Lohman, S.W., 1941 
Leavenworth

Hinds, Henry, and Greene, F.C., 1917

\section{Lincoin County}

Berry, D.W., 1952

\section{Linn County}

Falwell, Ronald, and others, 1990

Seevers, W.J., 1969

\section{Logan County}

Johnson, C.R., 1958

Keene, K.M., and Pabst, M.E., 1971

McClain, T.J., and others, 1975

\section{Lyon County}

Myers, N.C., and Bigsby, P.R., 1990

O'Connor, H.G., 1953

\section{M}

\section{Marienthal}

Dunlap, L.E., 1980

\section{Marshall County}

Walters, K.L., 1954

\section{McPherson County}

Waterman, W.D., 1952

\section{Meade County}

Frye, J.C., 1940; 1942

\section{Mlami County}

Gogel, Tony, 1981b

Miller, D.E., 1966

\section{Midwestern United States}

Brown, D.E., and others, 1990

Goolsby, D.A., and others 1990; 1991

Goolsby, D.A., and Thurman, E.M., 1990

Meyer, M.T., 1994

Meyer, M.T., and Thurman, E.M., 1993c

Scribner, E.A., and others, 1993; 1993a; 1993b; 1994

Thurman, E.M., and others, 1991; 1992

\section{Missouri}

Bevans, H.E., and others, 1984

Dugan, J.T., 1986

Fishel, V.C., and others, 1953

Hauth, L.D., and Carswell, W.J., Jr., 1978

Hauth, L.D., and others, 1981

Hedman, E.R., and Engel, G.B., 1989

Hedman, E.R., and others, 1987

Hinds, Henry, and Greene, F.C., 1917

Imes, J.L., 1989a; 1989b; 1989c; 1990a; 1990b; 1990c; 1990d; 1990e; 1990f

Imes, J.L., and Davis, J.V., 1990a; 1990b; 1991

Jorgensen, D.G., and others, 1993
Missouri-Continued

Jorgensen, D.G., and Signor, D.C., 1981

Marcher, M.V., and others, 1984

Smith, W.S.T., 1905

Smith, W.S.T., and Siebenthal, C.E., 1907

U.S. Geological Survey, 1952

Mitcheli County

Hodson, W.G., 1959

Leonard, A.R., 1952

Montgomery County

O'Connor, H.G., 1974

Morton County

McLaughlin, T.G., 1942

Mt. Hope

Hansen, C.V., 1991 a

$\mathbf{N}$

Nebraska

Bevans, H.E., and others, 1993

Dugan, J.T., 1986

Dugan, J.T., and others, 1990

Fallon, J.D., and McChesney, J.A., 1993

Feder, G.L., and Krothe, N.C., 1981

Gutentag, E.D., and others, 1984

Hedman, E.R., and Engel, G.B., 1989

Heimes, F.J., and Luckey, R.R., 1980; 1983

Helgesen, J.O., and others, 1993

Huntzinger, T.L., 1991

Jordan, P.R., and Stamer, J.K., 1991

Jorgensen, D.G., and others, 1993

Jorgensen, D.G., and Signor, D.C., 1981

Krothe, N.C., and others, 1982

Luckey, R.R., and others, 1988

Mundorff, J.C., and Waddell, K.M., 1966

Osterkamp, W.R., and others, 1981

Stamer, J.K., 1991; 1992

Stamer, J.K., and others, 1987; 1990

Stamer, J.K., and Zelt, R.B., 1991

Tanner, D.Q., and others, 1990

Trombley, T.J., and Kenny, J.F., 1992

Weeks, J.B., and others, 1988

\section{Nemaha County}

Ward, J.R., 1974

\section{Neosho County}

Jungmann, W.L., 1966

\section{Ness County}

Jenkins, E.D., and Pabst, M.E., 1977

\section{Nevada}

Perry, C.A., and others, 1993 
Neversink River [New York]

Fan, Jian, and others, 1994

\section{New Mexico}

Dugan, J.T., 1986

Dugan, J.T., and others, 1990

Gutentag, E.D., and others, 1984

Hedman, E.R., and Engel, G.B., 1989

Heimes, F.J., and Luckey, R.R., 1980; 1983

Jorgensen, D.G., and others, 1993

Jorgensen, D.G., and Signor, D.C., 1981

Krothe, N.C., and others, 1982

Luckey, R.R., and others, 1988

Snipes, R.J., and others, 1974

U.S. Geological Survey, 1966a

Weeks, J.B., and others, 1988

\section{North-central Kansas}

Bedinger, M.S., and Tanaka, H.H., 1962

Burnett, R.D., 1984

Burnett, R.D., and Reed, T.B., 1985; 1986

Duram, W.H., 1951

Dunlap, L.E., 1982

Follansbee, Robert, and Spiegel, J.B., 1937

Helgesen, J.O., and others, 1982

Jorgensen, D.G., and Stullken, L.E., 1981

Kansas Water Board, 1958-62

Kume, Jack, and others, 1985

McGovern, H.E., 1984

Reed, T.B., 1981

Spruill, T.B., 1985

Stullken, L.E., 1980; 1984

Watts, K.R., 1985

\section{Northeast Kansas}

Bayne, C.K., 1971; 1973

Bevans, H.E., 1982

Bevans, H.E., and others, 1993

Brewer, L.D., and others, 1994

Carswell, W.J., Jr., 1978a; 1978b; 1981

CarswelI, W.J., Jr., and Bond, S.V., 1980

Denne, J.E., 1979

Fallon, J.D., and McChesney, J.A., 1993

Fishel, V.C., 1948b

Follansbee, Robert, and Spiegel, J.B., 1937

Frye, J.C., and Walters, K.L., 1950

Furness, L.W., 1965b

Hansen, C.V., 1993a

Hedman, E.R., and Kastner, W.M., 1974

Hedman, E.R., and others, 1974

Jordan, P.R., 1979a; 1979b

Jordan, P.R., and Stamer, J.K., 1991

Kansas Water Board, 1958-62

LaRocque, G.A., Jr., 1966

Leonard, R.B., 1969b

Leeson, E.R., 1957

\section{Northeast Kansas-Continued}

Mundorff, J.C., and Scott, C.H., 1964

Mundorff, J.C., and Waddell, K.M., 1966

Myers, N.C., and Bigsby, P.R., 1989

O'Connor, H.G., 1971; 1973

Osterkamp, W.R., and Wiseman, A.G., 1980

Perry, C.A., 1994a

Pomes, M.L., and others, 1991

Stamer, J.K., and Zelt, R.B., 1990

Trombley, T.J., and Kenny, J.F., 1992

U.S. Geological Survey, 1980a; 1981a

Ward, J.R., 1971; 1973; 1974

Winslow, J.D., 1972

Wolf, R.J., and Helgesen, J.O., 1993

\section{Northwest Kansas}

Bradley, Edward, and Johnson, C.R., 1957

Hathaway, L.R., and others, 1979

Jenkins, E.D., and Pabst, M.E., 1975

Kastner, W.M., 1974

McClain, T.J., and Jenkins, E.D., 1971

Pabst, M.E., and Jenkins, E.D., 1973; 1976a

Pearl, R.H., and others, 1972

Spinazola, J.M., 1981

\section{Norton County}

Frye, J.C., and Leonard, A.R., 1949

\section{Oklahoma}

Albin, D.R., 1975

Dugan, J.T., 1986

Dugan, J.T., and others, 1990

Fader, S.W., and Morton, R.B., 1975a; 1975b

Feder, G.L., and Krothe, N.C., 1981

Gutentag, E.D., and others, 1984

Hedman, E.R., and Engel, G.B., 1989

Hedman, E.R., and others, 1987

Heimes, F.J., and Luckey, R.R., 1980; 1983

Imes, J.L., 1989b; 1989c; 1990a; 1990b; 1990c; 1990d; 1990e; 1990f

Imes, J.L., and Davis, J.V., 1990a; 1990b; 1991

Jorgensen, D.G., and others, 1993

Jorgensen, D.G., and Signor, D.C., 1981

Kroth, N.C., and Oliver, J.W., 1982

Kroth, N.C., and others, 1982

Luckey, R.R., and others, 1988

Marcher, M.V., and others, 1984

Morton, R.B., and Fader, S.W., 1975

U.S. Geological Survey, 1966a

Ward, P.E., and Leonard, A.R., 1961

Weeks, J.B., and others, 1988

\section{Olathe}

Rasmussen, P.P., 1994

Rasmussen, P.P., and others, 1994 
O'Connor, H.G., 1955

\section{Osborne County}

Leonard, A.R., 1952

\section{Ottawa County}

Mack, L.E., 1962

\section{P}

\section{Parsons}

Williams, C.C., 1944

\section{Pawnee County}

McLaughlin, T.G., 1949

\section{Phillips County}

Frye, J.C., and Leonard, A.R., 1949

Leonard, A.R., 1952

\section{Pittsburg}

Stramel, G.J., 1957

\section{Pratt County}

Gillespie, J.B., and Hargadine, G.D., 1994

Gillespie, J.B., and others, 1991

Layton, D.W., and Berry, D.W., 1973

\section{$\mathbf{R}$}

\section{Rawlins County}

Keene, K.M., and others, 1969

Walters, K.L., 1956

\section{Reno County}

Bayne, C.K., 1956a

Hansen, C.V., 1993c

Heck, B.A., and others, 1992

\section{Republic County}

Fader, S.W., 1968

Fishel, V.C., 1948a

\section{Rice County}

Bayne, C.K., and Ward, J.R., 1974

Fent, O.S., 1950

\section{Rush County}

Leonard, A.R., and Berry, D.W., 1961

McNellis, J.M., 1973

\section{Russell}

Durum, W.H., 1953

Latta, B.F., 1948b

\section{Russell County}

Frye, J.C., and others, 1943

\section{Salina}

Gillespie, J.B., and Hargadine, G.D., 1981

\section{Saline County}

Gogel, Tony, 1981b

Latta, B.F., 1949

Waterman, W.D., 1952

\section{Scott City}

Gillespie, J.B., and Hargadine, G.D., 1975

\section{Scott County}

Gutentag, E.D., and Stullken, L.E., 1976

Stullken, L.E., 1988b

Stullken, L.E., and others, 1974

Waite, H.A., 1947

\section{Sedgwick County}

Bevans, H.E., 1988; 1989b

Lane, C.W., and Miller, D.E., 1965a; 1965b

Latta, B.F., 1940

\section{Seward County}

Byrne, F.E., and McLaughlin, T.G., 1948

\section{Shawnee County}

Johnson, W.D., Jr., and others, 1967

\section{Sheridan County}

Bayne, C.K., 1956b

Keene, K.M., and others, 1969

\section{Sherman County}

Keene, K.M., and others, 1969

McClain, T.J., and Jenkins, E.D., 1971

Prescott, G.C., Jr., 1953b

\section{Smith County}

Leonard, A.R., 1952

\section{Smithville}

Hinds, Henry, and Greene, F.C., 1917

\section{South-central Kansas}

Albert, C.D., 1964

Albert, C.D., and Stramel, G.J., 1966

Barker, R.A., and others, 1981

Carr, J.E., and others, 1986

Dague, B.J., 1985a; 1986a; 1987a

Diaz, A.M., 1962b; 1965

Fader, S.W., and Stullken, L.E., 1976; 1977; 1978

Gillespie, J.B, and Hargadine, G.D., 1994

Gillespie, J.B., and others, 1991

Hansen, C.V., 1991a; 1993b: 1993c

Hathaway, L.R., and others, 1981

Heck, B.A., and others, 1992

Heidari, Manoutchehr, 1982 


\section{South-central Kansas-Continued}

Helgesen, J.O., 1990; 1991

Helgesen, J.O., and others, 1991a; 1991b; 1992a; $1993 ; 1994$

Helgesen, J.O., and Rutledge, A.T., 1989

Helgesen, J.O., and Thurman, E.M., 1988

Juracek, K.E., 1994a

Kansas Water Board, 1958-62

Latta, B.F., 1940

Layton, D.W., and Berry, D.W., 1973

Leonard, R.B., 1964b; 1964c; 1972

Leonard, R.B., and Kleinschmidt, M.K., 1976

Leonard, R.B., and Shah, K.L., 1964

Lohman, S.W., 1942

Lohman, S.W., and Frye, J.C., 1940

Myers, N.C., 1992

Myers, N.C., and others, 1993

Osterkamp, W.R., 1977b

Pabst, B.J., 1988

Pabst, M.E., 1979a; 1980; 1981; 1982a; 1983a

Pabst, M.E., and Dague, B.J., 1984a

Perry, C.A., 1984b

Richards, D.B., and Dunaway, T.W., 1972

Rutledge, A.T., and Helgesen, J.O., 1989a; 1990

Sophocleous, Marios, and Perry, C.A., 1987

Spinazola, J.M., and others, 1985

Spruill, T.B., 1988

Stramel, G.J., 1956; 1966

Stullken, L.E., and Fader, S.W., 1976

Stullken, L.E., and others, 1987

U.S. Geological Survey, 1980b; 1981b

Williams, C.C., and Lohman, S.W., 1949

\section{South Dakota}

Dugan, J.T., 1986

Dugan, J.T., and others, 1990

Feder, G.L., and Krothe, N.C., 1981

Gutentag, E.D., and others, 1984

Hedman, E.R., and Engel, G.B., 1989

Heimes, F.J., and Luckey, R.R., 1980; 1983

Jorgensen, D.G., and others, 1993

Jorgensen, D.G., and Signor, D.C., 1981

Krothe, N.C., and others, 1982

Luckey, R.R., and others, 1988

Weeks, J.B., and others, 1988

\section{Southeast Kansas}

Bevans, H.E., and Diaz, A.M., 1980

Carswell, W.J., Jr., 1979

Fader, S.W., and Morton, R.B., 1975a; $1975 b$

Hart, R.J., and Stiles, T.C., 1984

Kansas Water Board, 1958-62

Kenny, J.F., and McCauley, J.R., 1982; 1983

Lohman, S.W., and Burtis, V.M., 1953

Lohman, S.W., and others, 1953
Southeast Kansas-Continued

McNellis, J.M., and others, 1969

O'Connor, H.G., 1974

Parker, H.N., 1911

Pope, L.M., and Diaz, A.M., 1982

Schrader, F.C., 1908

Schrader, F.C., and Erasmus, Haworth, 1906

Williams, C.C., 1948

\section{Southeast Nebraska}

Brewer, L.D., and others, 1994

Trombley, T.J., and Kenny, J.F., 1992

\section{Southwest Kansas}

Barker, R.A., and others, 1981; 1983

Dealy, M.T., and others, 1984

Dunlap, L.E., and others, 1983; 1984; 1985

Fishel, V.C., 1952a

Frye, J.C., and Fishel, V.C., 1949

Gillespie, J.B., and others, 1969

Gutentag, E.D., and others, 1970; 1972; 1978; 1980; 1981

Gutentag, E.D., and Stullken, L.E., 1974

Hathaway, L.R., and others, 1978

Haworth, Erasmus, 1897

Hay, Robert, 1890

Jorgensen, D.G., and others, 1982

Krothe, N.C., and Oliver, J.W., 1982

Kume, Jack, and Spinazola, J.M., 1982; 1983; 1985

Lindgren, R.J., 1982

Lobmeyer, D.H., and Sauer, C.G., 1974

Lobmeyer, D.H., and Weakly, E.C., 1978; 1979

McGovern, H.E., 1971

McGovern, H.E., and Long, W.A., 1974

Meyer, W.R., and others, 1970

Pabst, M.E., 1978c

Pabst, M.E., and Gutentag, E.D., 1979

Pabst, M.E., and Jenkins, E.D., 1976b

Prill, R.C., 1968; 1977

Schumm, S.A., and Lichty, R.W., 1961; 1963

Spinazola, J.M., 1982a

Spinazola, J.M., and Dealy, M.T., 1983

Stullken, L.E., 1988a

Theis, C.V., and others, 1935

Thomas, H.E., 1962

Watts, K.R., 1985

\section{Stafford County}

Latta, B.F., 1950

\section{Stanton County}

Fader, S.W., and others, 1964

Latta, B.F., 1941

Nuzman, C.E., and Meyer, W.R., 1965

Winslow, J.D., and others, 1968 


\section{St. Francis}

Wolff, H.C., 1911

\section{Stevens County}

McLaughlin, T.G., 1946

\section{Sumner County}

Myers, N.C., and others, 1993

Walters, K.L., 1961

\section{Syracuse}

Darton, N.H., 1920

\section{$\mathbf{T}$}

\section{Texas}

Dugan, J.T., 1986

Dugan, J.T., and others, 1990

Feder, G.L., and Krothe, N.C., 1981

Gutentag, E.D., and others, 1984

Hedman, E.R., and Engel, G.B., 1989

Heimes, F.J., and Luckey, R.R., 1980; 1983

Jorgensen, D.G., and others, 1993

Jorgensen, D.G., and Signor, D.C., 1981

Krothe, N.C., and others, 1982

Luckey, R.R., and others, 1988

Ward, P.E., and Leonard, A.R., 1961

Weeks, J.B., and others, 1988

\section{Thomas County}

Frye, J.C., 1945

Keene, K.M., and others, 1969

Topeka

Davis, S.N., and Carlson, W.A., 1952

Perry, C.A., 1991e

Pope, L.M., and Bevans, H.E., 1984; 1987

Pope, L.M., and others, 1983

U.S. Geological Survey, 1958; 1959

Winslow, J.D., and Nuzman, C.E., 1966

\section{Towanda}

Leonard, R.B., and Shah, K.L., 1964

\section{Trego County}

Hodson, W.G., 1965

Leonard, A.R., and Berry, D.W., 1961

\section{U}

\section{United States}

Brown, D.E., and others, 1990

Busby, M.W., 1963; 1966

Clarke, F.W., 1924

Darton, N.H., 1905a

Fishel, V.C., 1956

Goolsby, D.A., and others 1990; 1991

Goolsby, D.A., and Thurman, E.M., 1990

\section{United States - Continued}

Hedman, E.R., and Osterkamp, W.R., 1982

Helgesen, J.O., and Leonard, R.B., 1988; 1989

Imes, J.L., 1989a

James, I.C., II, 1968

Jorgensen, D.G., 1989; 1993

Kolpin, D.W., and others 1993; 1994

Leonard, R.B., and others 1983

Meyer, M.T., 1994

Meyer, M.T., and Thurman, E.M., 1993c

Murphy, E.C., 1904

Murphy, E.C., and others, 1905

Osterkamp, W.R., and others, 1982

Peale, A.C., 1886; 1894

Perry, C.A., 1991f; 1992a; 1994b

Rosenshein, J.S., 1979

Rosenshein, J.S., and others, 1986

Scribner, E.A., and others, 1993; 1993a; 1993b; 1994

Signor, D.C., and Imes, J.L., 1989

Thurman, E.M., and others, 1991; 1992

U.S. Geological Survey, 1985

$$
\text { V }
$$

\section{Victoria}

Latta, B.F., $1948 b$

w

\section{Walker}

Latta, B.F., 1948 b

Wallace County

Hodson, W.G., 1963

Keene, K.M., and Pabst, M.E., 1971

McClain, T.J., and others, 1975

\section{Wamego}

Albert, C.D., 1973

Medina, K.D., 1987b

\section{West-central Kansas}

Dague, B.J., 1985b; 1986b; 1987b

Dunlap, L.E., 1980

Dunlap, L.E., and others, 1980

Dunlap, L.E., and Spinazola, J.M., 1981; 1984

Gillespie, J.B., and Perry, C.A., 1988

Gutentag, E.D., 1975

Hathaway, L.R., and others, 1975

Jenkins, E.D., and Pabst, M.E., 1977

Leonard, R.B., 1969a; 1970; 1974

McClain, T.J., and others, 1975

Pabst, B.J., 1991

Pabst, M.E., 1977b; 1978b; 1979b; 1982b

Pabst, M.E., and Dague, B.J., 1984b

Pabst, M.E., and Gutentag, E.D., 1977

Pabst, M.E., and Jenkins, E.D., 1974

Spinazola, J.M., 1982b 


\section{Western Kansas}

Baker, C.H., Jr., 1979; 1983

Bradley, Edward, and Johnson, C.R., 1957

Dague, B.J., 1985a; 1986a; 1987a

Gillespie, J.B., and Hargadine, G.D., 1975

Gillespie, J.B., and others, 1977

Gutentag, E.D., and Stullken, L.E., 1976

Jordan, P.R., 1977; 1982

Kume, Jack, 1984

Pabst, B.J., 1988

Pabst, M.E., 1977a; 1978a; 1979a; 1980; 1981; 1982a; 1983a

Pabst, M.E., and Dague, B.J., 1984a

Pabst, M.E., and Stullken, L.E., 1982; 1985; 1986; 1987

Perry, C.A., 1984a

Slagle, S.E., and Weakly, E.C., 1976

Slichter, C.S., 1906

Stullken, L.E., and others, 1985

Stullken, L.E., and Pabst, M.E., 1981; 1982

Watts, K.R., and Stullken, L.E., 1985

Western Plains

Hansen, C.V., and others, 1994

\section{Western United States}

Hedman, E.R., and Osterkamp, W.R., 1982

Meyers, J.S., 1962

Osterkamp, W.R., and others, 1982

Perry, C.A., 1992a; 1994b

\section{Wichita}

Ellis, D.W., and others, 1963

James, I.C., II, 1967

Lane, C.W., and others, 1962

Meinzer, O.E., 1915

Myers, N.C., 1992

Peek, C.O., and Jordan, P.R., 1978

Perry, C.A., and Hart, R.J., 1984

Petri, L.R., and others, 1964

Williams, C.C., and Lohman, S.W., 1947; 1949

\section{Wichita County}

Kume, Jack, and others, 1979

Prescott, G.C., Jr., and others, 1954

Slagle, S.E., and Weakly, E.C., 1976

Stullken, L.E., and others, 1974

\section{Winfield}

Leonard, R.B., and Shah, K.L., 1964

\section{Wyandotte County}

Hansen, C.V., 1993a

\section{Wyoming}

Dugan, J.T., and others, 1990

Gutentag, E.D., and others, 1984

Hedman, E.R., and Engel, G.B., 1989

Heimes, F.J., and Luckey, R.R., 1980; 1983

Jorgensen, D.G., and others, 1993

Krothe, N.C., and others, 1982

Luckey, R.R., and others, 1988

Weeks, J.B., and others, 1988 


\section{SUBJECT INDEX}

This index was compiled by scanning the report titles. It is intended as an aid in the initial search for topical subject matter. This index is arranged alphabetically by subject. The keyword sends you from a subject of interest to an author entry. Listings under each subject are arranged alphabetically by the author's last name and initials, followed by the year of publication. For a complete bibliographic citation, the reader should refer to "Alphabetical Listing by Author," beginning on page 3 .

\section{A}

\section{Alachlor}

Aga, D.S., and others, 1993; 1994

Aga, D.S., and Thurman, E.M., 1993a

\section{Alachlor ethanesulfonic acid}

Aga, D.S., and others, 1993

Aga, D.S., and Thurman, E.M., 1993b

Pomes, M.L., and others 1993a; 1993b

\section{Alachlor oxoacetic acid}

Pomes, M.L., and others 1993a; 1993b

\section{Alluvial channels}

Osterkamp, W.R., 1978b; 1979c; 1980

\section{Anadarko Basin}

Jorgensen, D.G., 1989

\section{Aqulfer tests}

Ehlig, Christine, and Halepaska, J.C., 1976

Hansen, C.V., 199lb

Jorgensen, D.G., and others, 1982

McElwee, C.D., 1977

Reed, T.B., and Burnett, R.D., 1985

U.S. Geological Survey, 1958

\section{Arbuckle rocks}

Carr, J.E., and McGovern, H.E., 1986

Gogel, Tony, 1981b

\section{Arkansas River}

Barker, R.A., and others, 1981; 1983

Dunlap, L.E., and others, 1983; 1984; 1985

Fader, S.W., and Morton, R.B., 1975a

Jordan, P.R., 1978b

Kansas Water Board, 1958-62

Lohman, S.W., and Burtis, V.M., 1953

Lohman, S.W., and others, 1953

Mueller, D.K., and others, 1991

Myers, N.C., 1992

Osterkamp, W.R., 1977b

Slichter, C.S., 1906

Snipes, R.J., and others, 1974

Spruill, T.B., 1990b

U.S. Geological Survey, 1955; 1980b; $1981 \mathrm{~b}$

Williams, C.C., 1946

\section{Atrazine}

Adams, C.D., 1991

Adams, C.D., and others, 1990

Cromwell, A.E., and Thurman, E.M., 1993a

Dankwardt, Andrea, and others, 1993

Fallon, J.D., 1994

Fallon, J.D., and Thurman, E.M., 1993a; 1993b

Mills, M.S., and others, 1991

Rutledge, A.T., and Helgesen, J.O., 1989a

Scribner, E.A., and others, 1993

Squillace, P.J., and others, 1993

Stamer, J.K., 1992

Stamer, J.K., and Zelt, R.B., 1992

Thurman, E.M., and others, 1991a; 1991 b

\section{Avallability of ground water}

Bayne, C.K., and Ward, J.R., 1967

Fishel, V.C., 1963

La Rocque, G.A., Jr., 1966

Lohman, S.W., and others, 1942; 1953

\section{B}

\section{Base flow}

Busby, M.W., and Armentrout, G.W., 1965

Furness, L.W., and Busby, M.W., 1967

Furness, L.W., and others, 1966

Spruill, T.B., 1985

Squillace, P.J., and others, 1993

\section{Big Blue River}

Leonard, R.B., 1969b

\section{Boreholes}

Darton, N.H., 1905a

\section{Brine}

Albert, C.D., 1964

Angino, E.E., and Morgan, C.O., 1966

Dingman, R.J., and Angino, E.E., 1969

Leonard, R.B., 1964a

McNellis, J.M., and others, 1969

\section{Buried valleys}

Denne, J.E., 1979 


\section{C}

\section{Cambrian rock}

Jorgensen, D.G., and others, 1986

Spinazola, J.M., and others, 1987

Wolf, R.J., and others, 1990

\section{Cedar Bluff irrigation District}

Leonard, R.B., 1969a; 1970; 1974

Leonard, R.B., and Stoltenberg, G.A., 1972

\section{Cedar River}

Thurman, E.M., and others, 1988

\section{Cenozoic deposits}

Bayne, C.K., and Ward, J.R., 1969

\section{Centrai Midwest regional aquifer}

Hedman, E.R., and Engel, G.B., 1989

Helgesen, J.O., and Hansen, C.V., 1989

Jorgensen, D.G., and Signor, D.C., 1981

\section{Channel geometry}

Burns, C.V., 1971

Hedman, E.R., and Kastner, W.M., 1972; 1974; 1977

Hedman, E.R., and Osterkamp, W.R., 1982

Hedman, E.R., and others, 1974

Osterkamp, W.R., 1978a; 1979a

Osterkamp, W.R., and Hedman, E.R., 1977; 1979; $1981 ; 1982$

Osterkamp, W.R., and others, 1981

\section{Chemicai quailty of ground water}

Adams, C.D., 1991

Adams, C.D., and others, 1990

Berry, D.W., 1952

Bradley, Edward, and Johnson, C.R., 1957

Dingman, R.J., 1969

Kume, Jack, 1984

Leonard, R.B., 1970

Leonard, R.B., and others, 1983

Perry, C.A., and others, 1988

Rutledge, A.T., and Helgesen, J.O., 1989a; 1990

Spruill, T.B., 1982; 1983a; 1983b; 1985

Spruill, T.B., and Kenny, J.F., 1981

Williams, C.C., 1948

\section{Chemicai quaiity of irrigation water}

Hathaway, L.R., and others, 1975; 1977; 1978; 1979; 1981

\section{Chemicai quaiity of surface water}

Bevans, H.E., 1982

Clarke, F.W., 1924

Diaz, A.M., 1962a; 1965

Durum, W.H., 1951; 1953

Jordan, P.R., and others, 1964

Leonard, R.B., 1964b; 1964c; 1969a; 1972; 1974
Chemical quality of surface water-Continued

Leonard, R.B., and Shah, K.L., 1964

Mayes, J.L., and Culbertson, Don, 1964

Mayes, J.L., and Diaz, A.M., 1965

Mayes, J.L., and others, 1965

Mundorff, J.C., and Waddell, K.M., 1966

Perry, C.A., and Anderson, M.R., 1991

Scribner, E.A., and others, 1993; 1993a; $1993 \mathrm{~b}$

Spruill, T.B., 1990b

Waterman, W.D., 1952

\section{Chloroacetaniilide}

Brown, D.E., and others, 1990

\section{Cimarron River}

Kansas Water Board, 1958-62

Schumm, S.A., and Lichty, R.W., 1961; 1963

U.S. Geological Survey, 1966a

\section{Climate characteristics}

Burns, C.V., and others, 1976

Busby, M.W., 1964

Jordan, P.R., 1979a

Meyers, J.S., 1962

Perry, C.A., 1980; 1987; 1990a; 1990c; 1991b; 1993a; $1993 b$

Thomas, H.E., 1962

Wolock, D.M., and McCabe, G.J., 1993

Zamarripa, G.T., and Perry, C.A., 1993

\section{Coal hydrology}

Bevans, H.E., 1980; 1984; 1986; 1989a

Bevans, H.E., and Diaz, A.M., 1980

Bevans, H.E., and others, 1984

Kenny, J.F., and McCauley, J.R., 1982; 1983

Kenny, J.F., and others, 1982

Marcher, M.V., and others, 1984

Osterkamp, W.R., and Hedman, E.R., 1979

Parker, H.N., 1911

Pope, L.M., and Diaz, A.M., 1982

\section{Computer appilications}

Angino, E.E., and Morgan, C.O., 1966

Barker, R.A., and others, 1981; 1983

Dabiri, H.E., and others, 1970

Dunlap, L.E., 1980

Dunlap, L.E., and others, 1980; 1983; 1985

Jorgensen, D.G., and others, 1982

Jorgensen, D.G., and Stullken, L.E., 1981

Juracek, K.E., 1992b; 1994b

Juracek, K.E., and Kenny, J.F., 1993b

Leonard, R.B., and Morgan, C.O., 1970

Longwill, S.M., and others, 1980

Lowell, B.H., and others, 1970

McClain, T.J., and Jenkins, E.D., 1971

McElwee, C.D., and Yukler, M.R., 1978

McNellis, J.M., and Morgan, C.O., 1969 


\section{Computer appiications-Continued}

McNellis, J.M., and others, 1968; 1969

Morgan, C.O., and McNellis, J. M., 1969a; 1969b; 1971

Morgan, C.O., and others, 1966; 1969

Richards, D.B., and Dunaway, T.W., 1972

Ropes, L.H., and others, 1969

Rosenshein, J.S., and McNellis, J.M., 1979

Rutledge, A.T., 1988; 1991

\section{Confined aquifers}

Ehlig, Christine, and Halepaska, J.C., 1976

\section{Cottonwood River}

Jordan, P.R., and Hart, R.J., 1985

\section{Council Grove Lake}

Carswell, W.J., Jr., and Hart, R.J., 1985

\section{Cretaceous rocks}

Keene, K.M., and Bayne, C.K., 1977

Kume, Jack, 1984

Kume, Jack, and Spinazola, J.M., 1983

Signor, D.C., and Imes, J.L., 1989

Spinazola, J.M., and others, 1987

Wolf, R.J., and others, 1990

\section{D}

\section{Dakota aquifer}

Dealy, M.T., and others, 1984

Helgesen, J.O., and others, 1982

Leonard, R.B., and others, 1983

Lobmeyer, D.H., and Weakly, E.C., 1978; 1979

McGovern, H.E., 1984

Watts, K.R., 1985a; 1985 b

\section{Dealkylation}

Mills, M.S., and Thurman, E.M., 1994a

\section{Deethyiatrazine}

Adams, C.D., and Thurman, E.M., 1991

Squillace, P.J., and others, 1993

\section{Delaware River [New Jersey]}

Wolock, D.M., and McCabe, G.J., 1993

Wolock, D.M., and others, 1993

\section{Dissolved solids}

Bevans, H.E., 1980

Imes, J.L., and Davis, J.V., 1990a; 1990b; 1991

Jorgensen, D.G., and others, 1986

Kroth, N.C., and others, 1982

\section{Drought}

Carswell, W.J., Jr., and Hart, R.J., 1985

Clement, R.W., 1991

Hart, R.J., and Stiles, T.C., 1984

Jordan, P.R., and Hart, R.J., 1985

\section{Drought-Continued}

Jordan, P.R., and Jennings, M.E., 1991

Thomas, H.E., 1962

\section{E}

\section{Elm Creek}

Williams, C.C., and Bayne, C.K., 1946

\section{Environmental assessment}

Albin, D.R., 1975

Kenny, J.F., and others, 1982

\section{Enzyme-linked immunosorbent assay}

Aga, D.S., and others, 1993; 1994

Aga, D.S., and Thurman, E.M., 1993a; 1993b

Dankwardt, Andrea, and others, 1993

Fallon, J.D., and Thurman, E.M., 1993a; 1993b

Goolsby, D.A., and others, 1990

Pomes, M.L., and others, 1991 a; $1991 \mathrm{~b}$

Pomes, M.L., and Thurman, E.M., 1990; 1991

Scribner, E.A., and others, 1993a; 1993b

Thurman, E.M., and others, 1990; 1991a; 1991b; 1992

Zimmerman, L.R., and others, 1993

\section{Equus beds}

Hathaway, L.R., and others, 1981

Lohman, S.W., and Frye, J.C., 1940

Spinazola, J.M., and others, 1985

Stramel, G.J., 1956; 1966

\section{Evaporation}

Meyers, J.S., 1962

\section{$\mathbf{F}$}

\section{Flood frequency}

Clement, R.W., 1983; 1987

Ellis, D.W., and Edelen, G.W., Jr., 1960

Irza, T.J., 1966

Jordan, P.R., and Irza, T.J., 1975

Perry, C.A., and Hart, R.J., 1984

\section{Floods}

Clement, R.W., 1987; 1991

Clement, R.W., and Johnson, D.G., 1982

Ellis, D.W., and others, 1963

Fischel, V.C., 1952b

Follansbee, Robert, and Spiegel, J.B., 1937

Furness, L.W., 1965b

Gillespie, J.B., and Perry, C.A., 1988

Hauth, L.D., and Carswell, W.J., Jr., 1978

Hauth, L.D., and others, 1981

James, I.C., II, 1967

Jordan, P.R., and Jennings, M.E., 1991

Medina, K.D., 1987b

Murphy, E.C., 1904 


\section{Floods-Continued}

Murphy, E.C., and others, 1905

Perry, C.A., 1984a; 1994a

Snipes, R.J., and others, 1974

U.S. Geological Survey, 1952; 1959

\section{Flow characteristics}

Burns, C.V., 1967; 1971; 1975

Burns, C.V., and others, 1976

Busby, M.W., and Armentrout, G.W., 1965

Ellis, D.W., and Edeline, G.W., Jr., 1960

Furness, L.W., 1959; 1960; 1962

Furness, L.W., and others, 1964; 1966

Hedman, E.R., and Engel, G.B., 1989

Hedman, E.R., and Kastner, W.M., 1972; 1974; 1977

Hedman, E.R., and others, 1987

Hedman, E.R., and Osterkamp, W.R., 1982

Jordan, P.R., and Irza, T.J., 1975

Osterkamp, W.R., and Hedman, E.R., 1982

Pope, L.M., and Bevans, H.E., 1984

\section{Flow duration}

Furness, L.W., 1959

Jordan, P.R., 1983

\section{Fluvial morphology}

Osterkamp, W.R., 1979b; 1980

\section{Fluvial sediment}

Albert, C.D., 1973

Albert, C.D., and Stramel, G.J., 1966

Bevans, H.E., 1982

Collins, D.L., 1965

Mundorff, J.C., 1961

Mundorff, J.C., and Scott, C.H., 1964

Mundorff, J.C., and Waddell, K.M., 1966

Osterkamp, W.R., 1977b

Skougstad, M.W., and others, 1979

\section{G}

\section{Gas chromatography/mass spectrometry}

Aga, D.S., and Thurman, E.M., 1993b

Dankwardt, Andrea, and others, 1993

Goolsby, D.A., and others, 1990

Helgesen, J.O., and Thurman, E.M., 1988

Meyer, M.T., and others, 1993

Pomes, M.L., and others, 199la; 1991b; 1993a; 1993b

Pomes, M.L., and Thurman, E.M., 1990; 1991

Scribner, E.A., and others, 1993a; 1993b

Thurman, E.M., and others, 1990; 1991a; 1991b; 1992

\section{Geographic information system (GIS)}

Fan, Jian, and others, 1994

Hansen, C.V., 1993a

Juracek, K.E., 1991; 1992b; 1992c; 1994b; 1994c

Juracek, K.E., and Kenny, J.F., 1993a; 1993b

Zelt, R.B., 1991

\section{Geohydrology}

Bayne, C.K., 1971; 1973

Carr, J.E., and others, 1986

Combs, L.J., and others, 1993

Dealy, M.T., and others, 1984

Dunlap, L.E., 1982

Dunlap, L.E., and others, 1980; 1983; 1985

Fader, S.W., and others, 1964

Fader, S.W., and Stullken, L.E., 1976; 1977; 1978

Gillespie, J.B., and Hargadine, G.D., 1986; 1994

Gillespie, J.B., and others, 1991

Gutentag, E.D., and others, 1980; 1981; 1984

Hansen, C.V., and others, 1992; 1994

Helgesen, J.O., and Leonard, R.B., 1988; 1989

Imes, J.L., 1989a; 1989b; 1989c; 1990a; 1990b; 1990c; 1990d; 1990e; $1990 \mathrm{f}$

Jorgensen, D.G., and others; 1993

Kenny, J.F., and others, 1993

Kume, Jack, 1984

Kume, Jack, and Spinazola, J.M., 1982; 1985

Lane, C.W., and Miller, D.E., 1965a

Leonard, R.B., and others, 1983

McGovern, H.E., 1984

McGovern, H.E., and Wolf, R.J., 1993

Meyer, W.R., and others, 1970

O'Connor, H.G., 1973

Richards, D.B., and Dunaway, T.W., 1972

Rosenshein, J.S., and Bennett, G.D., 1984

Signor, D.C., and Imes, J.L., 1989

Spinazola, J.M., and others, 1987; 1992

Stullken, L.E., and others, 1985

Ward, J.R., 1971; 1973; 1974

Waterman, W.D., 1952

Winslow, J.D., 1972

Wolf, R.J., and others, 1990; 1992

\section{Geology}

Bayne, C.K., 1956a; 1956b; 1960; 1962

Bayne, C.K., and others, 1971

Bayne, C.K., and Schoewe, W.H., 1967

Bayne, C.K., and Walters, K.L., 1959

Bayne, C.K., and Ward, J.R., 1974

Berry, D.W., 1952

Byrne, F.E., and McLaughlin, T.G., 1948

Darton, N.H., 1905b

Davis, S.N., and Carlson, W.A., 1952

Dufford, A.E., 1958

Fent, O.S., 1950

Fishel, V.C., 1948a

Fishel, V.C., and Leonard, A.R., 1955

Frye, J.C., 1942; 1945

Frye, J.C., and Leonard, A.R., 1949

Hay, Robert, 1890

Hodson, W.G., 1959; 1963; 1965; 1969

Hodson, W.G., and Wahl, K.D., 1960 


\section{Geology-Continued}

Johnson, C.R., 1958

Johnson, W.D., Jr., and others, 1967

Jungmann, W.L., 1966

Jungmann, W.L., and Williams, C.C., 1968

Lane, C.W., 1960

Latta, B.F., 1941; 1944; 1948a; 1950

Layton, D.W., and Berry, D.W., 1973

Leonard, A.R., 1952

Leonard, A.R., and Berry, D.W., 1961

Lohman, S.W., and Frye, J.C., 1940

Mack, L.E., 1962

McGovern, H.E., 1971

McLaughlin, T.G., 1942; 1943; 1946; 1949

McNellis, J.M., 1973

Miller, D.E., 1966; 1969

O'Connor, H.G., 1960; 1971; 1974

Prescott, G.C., Jr., 1951; 1953a; 1953b; 1955

Prescott, G.C., Jr., and others, 1954

Schrader, F.C., and Haworth, Erasmus, 1906

Seevers, W.J., 1969

Stramel, G.J., and others, 1958

Waite, H.A., 1942; 1947

Walters, K.L., 1953; 1954; 1956; 1961

Walters, K.L., and Bayne, C.K., 1959

Waterman, W.D., 1952

Williams, C.C., and Lohman, S.W., 1949

\section{Geomorphology}

Osterkamp, W.R., and others, 1978

\section{Glacial deposits}

Frye, J.C., and Walters, K.L., 1950

\section{Great Bend Prairie}

Fader, S.W., and Stullken, L.E., 1976; 1977; 1978

Hathaway, L.R., and others, 1978

Stullken, L.E., and Fader, S.W., 1976

\section{Great Plains}

Darton, N.H., 1905b

Hay, Robert, 1895

Hedman, E.R., and Engel, G.B., 1989

Helgesen, J.O., and Leonard, R.B., 1988; 1989

Helgesen, J.O., and others, 1993

Landis, E.R., 1960

McGovern, H.E., and Wolf, R.J., 1993

Spinazola, J.M., and others, 1992

\section{Ground-water dlscharge}

Gillespie, J.B., and Hargadine, G.D., 1981; 1986; 1994

Gogel, Tony, 1981a

\section{Ground-water levels}

Bedinger, M.S., and Tanaka, H.H., 1962

Broeker, M.E., and Fishel, V.C., 1961; 1962

Broeker, M.E., and McNellis, J.M., 1973

\section{Ground-water levels-Continued}

Broeker, M.E., and others, 1977

Broeker, M.E., and Winslow, J.D., 1963; 1964; 1965; 1966

Buddemeier, R.W., and others, 1991

Dague, B.J., 1985a; 1986a; 1987a; 1987b

Dunlap, L.E., 1980

Fishel, V.C., 1956

Fishel, V.C., and Broeker, M.E., 1960

Fishel, V.C., and others, 1959

Fishel, V.C., and Mason, B.J., 1957; 1958

Kume, Jack, and others, 1985

La Rocque, G.A., Jr., 1966

Lohman, S.W., and others, 1953

Luckey, R.R., and others, 1988

McGovern, H.E., and Long, W.A., 1974

Nuzman, C.E., and Meyer, W.R., 1965

Pabst, B.J., 1988

Pabst, M.E., 1977a; 1978a; 1979a; 1980; 1981; 1982a; $1983 a$

Pabst, M.E., and Dague, B.J., 1984a

Pabst, M.E., and Gutentag, E.D., 1977; 1979

Pabst, M.E., and Jenkins, E.D., 1973; 1974; 1976a; $1976 \mathrm{~b}$

Spruill, T.B., 1983a

Townsend, Margaret, and others, 1989

U.S. Geological Survey, 1952

Winslow, J.D., and others, 1964; 1968

\section{Ground-water movement}

Dingman, R.J., 1969

Jorgensen, D.G., and others, 1982

Prill, R.C., 1968; 1977

Rutledge, A.T., and Helgesen, J.O., 1990

Slichter, C.S., 1902; 1906

Ward, P.E., and Leonard, A.R., 1961

Wolff, H.C., 1911

\section{Ground-water quality}

Adams, C.D., and others, 1990

Baker, C.H., Jr., and Hansen, C.V., 1987; 1988

Berry, D.W., 1952

Falwell, Ronald, and others, 1990

Heck, B.A., and others, 1992

Helgesen, J.O., 1990; 1991

Helgesen, J.O., and others, 1993

Helgesen, J.O., and Perry, C.A., 1990

Helgesen, J.O., and Thurman, E.M., 1988

Imes, J.L., and Davis, J.V., 1990a; 1991

Leonard, R.B., 1970

Mills, M.S., and Thurman, E.M., 1994b

Myers, N.C., and Bigsby, P.R., 1989; 1990

Myers, N.C., and others, 1993

Perry, C.A., and others, 1988

Plummer, L.N., and others, 1993 
Ground-water quality-Continued

Rasmussen, P.P., 1994

Rasmussen, P.P., and others, 1994

Spruill, T.B., 1982; 1983b; 1984a; 1984b; 1985; $1987 \mathrm{a} ; 1989 ; 1990 \mathrm{a} ; 1990 \mathrm{~b}$

U.S. Geological Survey, 1966b; 1967b; 1968b; 1970b; 1970c; 1971b; 1971c; 1972b; 1973b; 1974b; $1975 b$

\section{Ground-water recharge}

Gillespie, J.B., and Hargadine, G.D., 1975

Gillespie, J.B., and others, 1969; 1970; 1977

Gillespie, J.B., and Slagle, S.E., 1972

Hansen, C.V., 1991b

Jorgensen, D.G., and others, 1989a; 1989b

Perry, C.A., 1984b

Sophocleous, Marios, and Perry, C.A., 1984; 1985; 1987

Stullken, L.E., 1988b

\section{Ground-water resources}

Bayne, C.K., 1956a; 1956b; 1958; 1960; 1962

Bayne, C.K., and others, 1971

Bayne, C.K., and Schoewe, W.H., 1967

Bayne, C.K., and Walters, K.L., 1959

Bayne, C.K., and Ward, J.R., 1967

Berry, D.W., 1952

Bevans, H.E., 1989b

Bevans, H.E., and others, 1985

Bradley, Edward, and Johnson, C.R., 1957

Bryne, F.E., and McLaughlin, T.G., 1948

Combs, L.J., and Huntzinger, T.L., 1988

Darton, N.H., 1905b

Davis, S.N., and Carlson, W.A., 1952

Dufford, A.E., 1958

Fader, S.W., 1968; 1974

Fader, S.W., and Morton, R.B., 1975a; $1975 b$

Fent, O.S., 1950

Fishel, V.C., 1947a; 1948a; 1948b; 1952a

Fishel, V.C., and Leonard, A.R., 1955

Fishel, V.C., and others, 1953

Frye, J.C., 1941; 1942; 1945

Frye, J.C., and Fishel, V.C., 1949

Frye, J.C., and Leonard, A.R., 1949

Frye, J.C., and others, 1943

Geiger, C.O., and others, 1983; 1984; 1985; 1986;

$1987 ; 1988 ; 1989 ; 1990 ; 1991 ; 1992 ; 1993 ; 1994$

Gutentag, E.D., and others, 1970; 1972

Gutentag, E.D., and Stullken, L.E., 1974; 1976

Hansen, C.V., 1993a; 1993b; 1993c

Haworth, Erasmus, 1897

Hay, Robert, 1895

Hodson, W.G., 1959; 1963; 1965; 1969

Hodson, W.G., and Wahl, K.D., 1960

Jenkins, E.D., and Pabst, M.E., 1977
Ground-water resources-Continued

Johnson, C.R., 1956; 1958

Jungmann, W.L., 1966

Jungmann, W.L., and Williams, C.C., 1968

Keene, K.M., and Bayne, C.K., 1977

Lane, C.W., 1960

Latta, B.F., 1941; 1944; 1948a; 1948b; 1949; 1950

Layton, D.W., and Berry, D.W., 1973

Leonard, A.R., 1952

Leonard, A.R., and Berry, D.W., 1961

Lobmeyer, D.H., and Sauer, C.G., 1974

Lohman, S.W., 1941; 1942

Lohman, S.W., and Frye, J.C., 1940

Mack, L.E., 1962

McClain, T.J., and others, 1975

McGovern, H.E., 1971

McGovern, H.E., and Long, W.A., 1974

McLaughlin, T.G., 1942; 1943; 1946; 1949

McNellis, J.M., 1973

Meinzer, O.E., 1915

Miller, D.E., 1966; 1969

Moore, R.C., 1940

Morton, R.B., and Fader, S.W., 1975

O'Connor, H.G., 1949; 1951; 1953; 1955; 1960; 1971; 1974

Pearl, R.H., and others, 1972

Petri, L.R., and others, 1964

Prescott, G.C., Jr., 1948; 1951; 1953a; 1953b; 1955

Prescott, G.C., Jr., and others, 1954

Roberts, R.S., and Hodson, W.G., 1966

Rosenshein, J.S., 1979

Seevers, W.J., 1969

Slagle, S.E., and Weakly, E.C., 1976

Smith, W.S.T., 1905

Spruill, T.B., 1984a; 1987b

Stramel, G.J., 1956; 1966

Stramel, G.J., and others, 1958

Theis, C.V., and others, 1935

Trombley, T.J., and Kenny, J.F., 1992

U.S. Geological Survey, 1964a; 1966a; 1966c; 1966d; 1967a; 1967b; 1968a; 1968b; 1969a; 1969b; 1970a; 1970b; 1970c; 1971b; 1971c; 1972b; 1972c; 1973b; 1974b; 1975b; 1976; 1977; 1978; 1978b; 1978c; 1978d; 1979; 1980a; 1980b; 1981a; 1981b; 1982

Waite, H.A., 1942; 1947

Walters, K.L., 1953; 1954; 1956; 1961

Walters, K.L., and Bayne, C.K., 1959

Williams, C.C., 1944; 1946

Williams, C.C., and Bayne, C.K., 1946

Williams, C.C., and Lohman, S.W., 1947; 1949 


\section{Ground-water withdrawals}

Baker, C.H., Jr., 1979a; 1983

Dunlap, L.E., and others, 1984

Heimes, F.J., and Luckey, R.R., 1983

Kastner, W.M., 1974

Lindgren, R.J., 1982

Richards, D.B., and Dunaway, T.W., 1972

Watts, K.R., 1985

\section{H}

\section{Herbicide transport}

Barnes, Philip, and Perry, C.A., 1990

Cromwell, A.E., and Thurman, E.M., 1993b

Fallon, J.D., and Thurman, E.M., 1993a; 1993b

Leahy, P.P., and Stamer, J.K., 1994

Meyer, M.T., and Thurman, E.M., 1993a; 1993b; $1993 \mathrm{c}$

Perry, C.A., 1990b; 1991e; $1991 \mathrm{~g}$

Perry C.A., and Barnes, P.L., 1990

Shamet, K.A., 1992

Squillace, P.J., and Thurman, E.M., 1992

Thurman, E.M., 1993a; 1993b

Thurman, E.M., and Mills, M.S, 1991

Thurman, E.M., and others, 1988; 1990; 1991; 1993

\section{Hlah flow}

Furness, L.W., and others, 1964

Jordan, P.R., 1978a; 1984; 1986b

\section{High Plalns}

Heimes, F.J., and Luckey, R.R., 1980; 1983

Johnson, W.D., 1901; 1902

Theis, C.V., and others, 1935

\section{Hlgh Plains aquifer}

Dague, B.J., 1985b; 1986b; 1987b

Dugan, J.T., and others, 1990

Gutentag, E.D., and others, 1984

Helgesen, J.O., 1990

HeIgesen, J.O., and others, 1991 a, 1991b, 1994

Helgesen, J.O., and Rutledge, A.T., 1989

Kroth, N.C., and Oliver, J.W., 1982

Kroth, N.C., and others, 1982

Luckey, R.R., and others, 1988

Pabst, B.J., 1991

Pabst, M.E., 1982b

Pabst, M.E., and Dague, B.J., 1984b

Pabst, M.E., and Stullken, L.E., 1981; 1982; 1985; 1986; 1987

Spinazola, J.M., 1982a

Stullken, L.E., 1988a

Stullken, L.E., and others, 1985; 1987

Stullken, L.E., and Pabst, M.E., 1981; 1982

Watts, K.R., and Stullken, L.E., 1985

Weeks, J.B., and others, 1988
Holocene

Perry, C.A., 1991a

Hydrochemistry

Imes, J.L., 1989a

Leonard, R.B., and others, 1983

\section{Hydrogeology}

Dealy, M.T., and others, 1984

Falwell, Ronald, and others, 1990

Heck, B.A., and others, 1992

Helgesen, J.O., and others, 1993

Jorgensen, D.G., 1988a; 1988b

Keene, K.M., and others, 1969

Keene, K.M., and Pabst, M.E., 1971

Myers, N.C., and Bigsby, P.R., 1989; 1990

Myers, N.C., and others, 1993

Rasmussen, P.P., 1994

Rasmussen, P.P., and others, 1994

Rosenshein, J.S., 1988

Rosenshein, J.S., and others, 1986

Stullken, L.E., 1980

Stullken, L.E., and Fader, S.W., 1976

Stullken, L.E., and others, 1974

Waterman, W.D., 1952

\section{Hydrology}

Barker, R.A., and others, 1981; 1983

Bayne, C.K., and Ward, J.R., 1974

Bevans, H.E., 1984; 1989a

Bevans, H.E., and others, 1984; 1985

Brewer, L.D., and others, 1994

Carswell, W.J., Jr., 1978a; 1978b; 1981

Clement, R.W., 1991

Dugan, J.T., 1986

Dunlap, L.E., and Spinazola, J.M., 1981

Hart, R.J., and Spruill, T.B., 1988

Helgesen, J.O., and others, 1993

Jordan, P.R., 1986a

Jordan, P.R., and Jennings, M.E., 1991

Jorgensen, D.G., and Stullken, L.E., 1981

Kenny, J.F., 1993

Kenny, J.F., and McCauley, J.R., 1983

Kenny, J.F., and others, 1982

Kume, Jack, and others, 1979

Marcher, M.V., and others, 1984

Morgan, C.O., and others, 1969

Spinazola, J.M., 1982a; 1982b

Spinazola, J.M., and Dealy, M.T., 1983

Squillace, P.J., and Thurman, E.M., 1992

Stramel, G.J., 1956; 1966

Stramel, G.J., and others, 1958

Stullken, L.E., 1984; 1988a

Waterman, W.D., 1952

Watts, K.R., 1985

Winslow, J.D., and Nuzman, C.E., 1966

Wolock, D.M., 1993c

Zelt, R.B., 1991 


\section{Hydroxyatrazine}

Pomes, M.L., and others, 1993a; $1993 \mathrm{~b}$

\section{I}

\section{Indian lands}

Brewer, L.D., and others, 1994

\section{Instrumentation}

Baker, C.H., Jr., 1979

Carswell, W.J., Jr., 1978a

Pope, L.M., and others, 1988

Prill, R.C., and Meyer, W.R., 1968

Sophocleous, Marios, and Perry, C.A., 1984

Wolock, D.M., 1993b

\section{Interior Province}

Bevans, H.E., 1989a

Bevans, H.E., and others, 1984

Marcher, M.V., and others, 1984

\section{Irrigation}

Baker, C.H., Jr., 1983

Burnett, R.D., and Reed, T.B., 1986

Goolsby, D.A., and others, 1991

Hathaway, L.R., and others, 1975; 1977; 1978; 1979; 1981

Heimes, F.J., and Luckey, R.R., 1983

Jenkins, E.D., and Pabst, M.E., 1975

Leonard, R.B., 1969a;

Lindgren, R.J., 1982

Meinzer, O.E., 1915

Perry, C.A., and Anderson, M.R., 1991

Spruill, T.B., 1985

\section{Isocratic separation}

Pomes, M.L., and others, 1993a; 1993b

\section{$\mathbf{J}$}

\section{Joplin district}

Smith, W.S.T., 1905

Smith, W.S.T., and Siebenthal, C.E., 1907

\section{Jurassic rock}

Kume, Jack, 1984

Kume, Jack, and Spinazola, J.M., 1983

\section{$\mathbf{K}$}

\section{Kanopolis Reservoir}

Waterman, W.D., 1952

\section{Kansas River}

Albert, C.D., 1973

Davis, S.N., and Carlson, W.A., 1952

Dufford, A.E., 1953

Fader, S.W., 1974
Kansas River-Continued

Fallon, J.D., and McChesney, J.A., 1993

Follansbee, Robert, and Spiegel, J.B., 1937

Jordan, P.R., and Stamer, J.K., 1991

Kansas Water Board, 1958-62

Leahy, P.P., and Stamer, J.K., 1994

Leeson, E.R., 1957

Medina, K.D., 1987b

Mundorff, J.C., and Scott, C.H., 1964

Osterkamp, W.R., and others, 1981

Perry, C.A., 1994a

Perry, C.A., and Barnes, P.L., 1990

Perry, C.A., and Studley, S.E., 1994

Stamer, J.K., 1991; 1992

Stamer, J.K., and others, 1987; 1990

Stamer, J.K., and Zelt, R.B., 1991; 1992; 1994

Tanner, D.Q., and others, 1990

U.S. Geological Survey, 1959

Winslow, J.D., and Nuzman, C.E., 1966

Wolf, R.J., and Helgesen, J.O., 1993

\section{Kirwin Reservoir}

Bedinger, M.S., and Tanaka, H.H., 1962

Burnett, R.D., 1984

Jorgensen, D.G., and Stullken, L.E., 1981

\section{Ladder Creek}

Bradley, Edward, and Johnson, C.R., 1957

\section{Landfill hydrology}

Falwell, Ronald, and others, 1990

Heck, B.A., and others, 1992

Helgesen, J.O., and others, 1993

Myers, N.C., and Bigsby, P.R., 1989; 1990

Myers, N.C., and others, 1993

Rasmussen, P.P., 1994

Rasmussen, P.P., and others, 1994

\section{Landfills}

Falwell, Ronald, and others, 1990

Heck, B.A., and others, 1992

Helgesen, J.O., and others, 1993

Myers, N.C., and Bigsby, P.R., 1989; 1990

Myers, N.C., and others, 1993

Rasmussen, P.P., 1994

Rasmussen, P.P., and others, 1994

\section{Little Arkansas River}

Albert, C.D., 1964

Albert, C.D., and Stramel, G.J., 1966

Leonard, R.B., and Kleinschmidt, M.K., 1976

Richards, D.B., and Dunaway, T.W., 1972

Little Blue River

Mundorff, J.C., and Waddell, K.M., 1966 


\section{Low flows}

Carswell, W.J., Jr., 1979

Carswell, W.J., Jr., and Bond, S.V., 1980

Furness, L.W., 1960

Jordan, P.R., 1983

Leonard, R.B., 1969a

\section{M}

\section{Marais des Cygnes River}

Kansas Water Board, 1958-62

\section{Msrion Lake}

Jordan, P.R., and Hart, R.J., 1985

\section{Methodology}

Aga, D.S., and Thurman, E.M., 1993a; 1993b

Aga, D.S., and others, 1993; 1994

Angino, E.E., and Morgan, C.O., 1966

Baker, C.H., Jr., 1979; 1983

Bevans, H.E., 1980

Clement, R.W., 1987

Dankwardt, Andrea, and others, 1993

Dunlap, L.E., and Spinazola, J.M., 1984

Ehlig, Christine, and Halepaska, J.C., 1976

Fishel, V.C., 1947b

Furness, L.W., and Busby, M.W., 1967

Goolsby, D.A., and others, 1990

Halepaska, J.C., and Hartman, J.W., 1972

Hansen, C.V., 1991a

Heimes, F.J., and Luckey, R.R., 1980

Hejl, H.R., Jr., 1977

Jorgensen, D.G., and others, 1982; 1989b

Juracek, K.E., 1991; 1992b; 1992c

Juracek, K.E., and Kenny, J.F., 1993a; 1993b

Kastner, W.M., 1974

Kenny, J.F., and McCauley, J.R., 1983

Leonard, R.B., 1964a

Leonard, R.B., and Morgan, C.O., 1970

Lindgren, R.J., 1982

McElwee, C.D., 1977

Medina, K.D., 1987a

Meyer, M.T., and others, 1993

Meyer, W.R., 1963

Morgan, C.O., and others, 1966

Osterkamp, W.R., 1978a; 1979a; 1979b

Osterkamp, W.R., and Hedman, E.R., 1979

Osterkamp, W.R., and others, 1978

Perry, C.A., 1984a

Perry, C.A., and Barnes, P.L., 1990

Perry, C.A., and others, 1993

Perry, C.A., and Thurman, E.M., 1989

Pomes, M.L., and others, 1993a; 1993b

Pomes, M.L., and Thurman, E.M., 1990; 1991

Prill, R.C., and Meyer, W.R., 1968; 1969

Skougstad, M.W., and others, 1979

\section{Methodology - Continued}

Spruill, T.B., 1987a

Thurman, E.M., and others, 1990

Williams, C.C., and Lohman, S.W., 1947

Winslow, J.D., and Nuzman, C.E., 1966

Wolock, D.M., 1993b

Wolock, D.M., and Price, C.V., 1994

Zelt, R.B., 1990; 1991

\section{Mississippian-age rock}

Jorgensen, D.G., and others, 1986

\section{Mississippi River}

Perry, C.A., 1994a

\section{Missouri River}

Hedman, E.R., and Kastner, W.M., 1974; 1977

Jordan, P.R., 1979a; 1979b

Kansas Water Board, 1958-62

La Rocque, G.A., Jr., 1966

Osterkamp, W.R., and Hedman, E.R., 1982

Osterkamp, W.R., and Wiseman, A.G., 1980

Perry, C.A., 1994a

U.S. Geological Survey, 1980a; 1981a

\section{$\mathbf{N}$}

\section{Nebraska River Basins}

Huntzinger, T.L., 1991

\section{Neosho River}

Carswell, W.J., Jr., and Hart, R.J., 1985

Hart, R.J., and Stiles, T.C., 1984

Kansas Water Board, 1958-62

Morton, R.B., and Fader, S.W., 1975

Williams, C.C., 1944

\section{Nitrate}

Kolpin, D.W., and others, 1993; 1994

Scribner, E.A., and others, 1993

Spruill, T.B., 1982; 1983a

\section{Nitrogen}

Spruill, T.B., 1982

Stamer, J.K., and Zelt, R.B., 1991; 1992

\section{North Fork Solomon River}

Burnett, R.D., 1984

Jorgensen, D.G., and Stullken, L.E., 1981

Kansas Water Board, 1958-62

Leonard, A.R., 1952

\section{Norton Dam}

Stullken, L.E., 1984 
0

\section{Observation wells}

Broeker, M.E., and Fishel, V.C., 1961; 1962

Broeker, M.E., and McNellis, J.M., 1973

Broeker, M.E., and others, 1977

Broeker, M.E., and Winslow, J.D., 1963; 1964; 1965; 1966

Dague, B.J., and Stullken, L.E., 1986

Fishel, V.C., and Broeker, M.E., 1960

Fishel, V.C., and Mason, B.J., 1957; 1958

Fishel, V.C., and others, 1959

Gogel, Tony, 1981b

Lane, C.W., and Miller, D.E., 1965b

Pabst, M.E., 1983b

Perry, C.A., and Hart, R.J., 1985

Spruill, T.B., and Kenny, J.F., 1981

\section{Ogallala aquifer}

Dunlap, L.E., and Spinazola, J.M., 1981

Feder, G.L., and Krothe, N.C., 1981

McClain, T.J., and Jenkins, E.D., 1971

McGovern, H.E., 1971

Spinazola, J.M., 1982b

Spinazola, J.M., and Dealy, M.T., 1983

\section{Ordovician rocks}

Jorgensen, D.G., and others, 1986

Stramel, G.J., 1957

\section{Organonitrogen}

Stamer, J.K., and Zelt, R.B., 1994

\section{Ozark Plateaus}

Imes, J.L., 1989a; 1989b; 1989c; 1990a; 1990b; 1990c; 1990d; 1990e; 1990f

Imes, J.L., and Davis, J.V., 1991

\section{$\mathbf{P}$}

\section{Paleohydrology}

Jorgensen, D.G., 1989; 1993

\section{Pawnee Rlver}

Gillespie, J.B., and Perry, C.A., 1988

\section{Pawnee Valiey}

Fishel, V.C., 1952a

Heidari, Manoutchehr, 1982

\section{Permian rock}

Gogel, Tony, 1981a

Kume, Jack, and Spinazola, J.M., 1983

\section{Pleistocene}

Gutentag, E.D., and Galli-Olivier, Carlos, 1969

McGovern, H.E., 1971

Perry, C.A., 1991 a

\section{Prairie Dog Creek}

Johnson, C.R., 1956

Stullken, L.E., 1984

\section{Prairie Natlonal Park}

Albin, D.R., 1975

\section{Precipitation}

Cromwell, A.E., and Thurman, E.M., 1993a; 1993b

Perry, C.A., 1980; 1981; 1991c; 1991f; 1992a; 1992b; 1992c; 1993a; 1994b

Zamarripa, G.T., and Perry, C.A., 1993

\section{$\mathbf{Q}$}

\section{Quaternary}

Dufford, A.E., 1958

Perry, C.A., 1991a

\section{$\mathbf{R}$}

\section{Rainfall-runoff relations}

Clement, R.W., 1983

Jordan, P.R., 1982

Peek, C.O., and Jordan, P.R., 1978

\section{Red River}

Lohman, S.W., and Burtis, V.M., 1953

Lohman, S.W., and others, 1953

\section{Remote sensing}

Kenny, J.F., and McCauley, J.R., 1982; 1983

\section{Repubilican River}

Dunlap, L.E., 1982

Fader, S.W., 1968

Follansbee, Robert, and Spiegel, J.B., 1937

Kansas Water Board, 1958-62

\section{Reservoir storage}

Carswell, W.J., Jr., 1982

Furness, L.W., 1962

Furness, L.W., and others, 1964

Perry, C.A., 1994a

Perry, C.A., and Studley, S.E., 1994

\section{Rock Creek Basin}

Furness, L.W., 1965b

\section{Runoff}

Barnes, Philip, and Perry, C.A., 1990

Busby, M.W., 1963; 1964; 1966

Furness, L.W., 1965a

Hedman, E.R., and Kastner, W.M., 1972

James, I.C., II, 1967

Jordan, P.R., 1982

Perry, C.A., and Barnes, P.L., 1990

Perry, C.A., and Thurman, E.M., 1989

Pomes, M.L., and Thurman, E.M., 1991 


\section{Runoff-Continued}

Pomes, M.L., and others, 1991a; $1991 \mathrm{~b}$

Pope, L.M., and Hess, L.G., 1989

Scribner, E.A., and others, 1994

\section{$\mathbf{S}$}

\section{Saline River}

Durum, W.H., 1951; 1953

Jordan, P.R., and others, 1964

Kansas Water Board, 1958-62

\section{Saline water}

Gillespie, J.B., and Hargadine, G.D., 1981; 1986; 1994

Gogel, Tony, 1981a

Leonard, R.B., and Kleinschmidt, M.K., 1976

Leonard, R.B., and Morgan, C.O., 1970

\section{Salt}

Fader, S.W., 1975

Ward, P.E., and Leonard, A.R., 1961

\section{Sandstone aquifers}

Kume, Jack, and Spinazola, J.M., 1982; 1985

\section{Saturated thickness}

Bayne, C.K., and Ward, J.R., 1969

Dague, B.J., 1985b; 1986b; 1987b

Gutentag, E.D., 1975

Gutentag, E.D., and others, 1978

Pabst, B.J., 1991

Pabst, M.E., 1977b; 1978b; 1978c; 1979b; 1982b

Pabst, M.E., and Dague, B.J., 1984b

\section{Sedgwick County Lake}

Latta, B.F., 1940

\section{Sediment}

Albert, C.D., 1962; 1969; 1973

Albert, C.D., and Stramel, G.J., 1966

Bevans, H.E., 1982

Collins, D.L., 1965

Jordan, P.R., 1979a; 1985

Jordan, P.R., and others, 1964

Meyer, M.T., and others, 1989

Mills, M.S., and Thurman, E.M., 1992

Mueller, D.K., and others, 1991

Mundorff, J.C., 1958; 1961

Mundorff, J.C., and Scott, C.H., 1964

Mundorff, J.C., and WaddelI, K.M., 1966

Osterkamp, W.R., 1977a; 1977b; 1978b; 1979c; 1980

Osterkamp, W.R., and Hedman, E.R., 1982

Osterkamp, W.R., and others, 1981; 1982

Osterkamp, W.R., and Wiseman, A.G., 1980

Skougstad, M.W., and others, 1979

Tanner, D.Q., and others, 1990

\section{Seepage}

Jordan, P.R., 1978a

Leonard, R.B., and Morgan, C.O., 1970

\section{Shunganunga Creek}

Pope, L.M., and Bevans, H.E., 1984; 1987

Pope, L.M., and others, 1983

\section{Sleepers River [Vermont]}

Wolock, D.M., 1993a

\section{Smoky Hill River}

Gillespie, J.B., and Hargadine, G.D., 1981; 1986

Kansas Water Board, 1958-62

Latta, B.F., 1949

\section{Soldier Creek}

Carswell, W.J., Jr., 1978a; 1978b; 1981

\section{Solid-phase extraction (SPE)}

Aga, D.S., and others, 1993

Aga, D.S., and Thurman, E.M., 1993a; 1993b

Meyer, M.T., and others, 1993

Mills, M.S., and others, 1993

Mills, M.S., and Thurman, E.M., 1992

Zimmerman, L.R., and Thurman, E.M., 1993

\section{Solomon River}

Gillespie, J.B., and Hargadine, G.D., 1986

Kansas Water Board, 1958-62

Reed, T.B., 1981

\section{South Fork Ninnescah River}

Diaz, A.M., 1965

Gillespie, J.B., and Hargadine, G.D., 1994

Gillespie, J.B., and others, 1991

\section{South Fork Solomon River}

Burnett, R.D., and Reed, T.B., 1985; 1986

Kume, Jack, and others, 1985

\section{Specific yield}

Bayne, C.K., and Ward, J.R., 1969

\section{Springs}

Hedman, E.R., and others, 1987

Peale, A.C., 1886; 1894

Ward, P.E., and Leonard, A.R., 1961

\section{Statistical analysis}

Bevans, H.E., and Diaz, A.M., 1980

Jordan, P.R., 1978b; 1979b

Kastner, W.M., 1974

Perry, C.A., and Anderson, M.R., 1991

Pope, L.M., and Diaz, A.M., 1982

Pope, L.M., and others, 1983

Spruill, T.B., 1983b; 1985; 1990a 


\section{Starch encapsuiation}

Mills, M.S., and others, 1990; 1991a; 1991b

Mills, M.S., and Thurman, E.M., 1994b

\section{Stream-aquifer hydrology}

Barker, R.A., and others, 1981; 1983

\section{Stream-aquifer interactions}

Bevans, H.E., 1986

Burnett, R.D., and Reed, T.B., 1985

Dunlap, L.E., and others, 1983; 1985

Gogel, Tony, 1981a

Jorgensen, D.G., and others, 1989a; 1989b

Kume, Jack, and others, 1985

\section{Stream chemistry}

Fan, Jian, and others, 1994

\section{Streamfiow characteristics}

Burns, C.V., 1967; 1971; 1975

Burns, C.V., and others, 1976

Busby, M.W., and Armentrout, G.W., 1965

Ellis, D.W., and Edelen, G.W., Jr., 1960

Furness, L.W., 1959; 1960; 1962

Furness, L.W., and others, 1964; 1966

Hedman, E.R., and Engel, G.B., 1989

Hedman, E.R., and Kastner, W.M., 1972; 1974; 1977

Hedman, E.R., and Osterkamp, W.R., 1982

Hedman, E.R., and others, 1974; 1987

James, I.C., II, 1968

Jordan, P.R., 1977

Jordan, P.R., and Irza, T.J., 1975

Osterkamp, W.R., 1978b; 1979c

Osterkamp, W.R., and Hedman, E.R., 1977; 1979; $1981 ; 1982$

Osterkamp, W.R., and others, 1980; 1982

\section{Streamflow measurements}

Bevans, H.E., 1986

Davis, A.P., 1897

Furness, L.W., 1957

Geiger, C.O., and others, 1983; 1984; 1985; 1986; $1987 ; 1988 ; 1989 ; 1990 ; 1991 ; 1992 ; 1993 ; 1994$

Jordan, P.R., 1977; 1978a; 1979b

Jordan, P.R., and Hedman, E.R., 1970

Medina, K.D., and Geiger, C.O., 1984

Newell, F.H., 1898; 1899; 1900; 1901

U.S. Geological Survey, 1962; 1963; 1964b; 1965; 1966c; 1967a; 1968a; 1969a; 1970a; 1971a; 1972a; 1973a; 1974a; 1975a; 1976; 1977; 1978a; 1978b; 1979; 1980a; 1980b; 1981a; 1981b; 1982

\section{S-triazines}

Mills, M.S., and Thurman, E.M., 1994

\section{Suifate}

Bevans, H.E., 1980

Imes, J.L., and Davis, J.V., 1990a; 1990b; 1991

\section{Surface-water quality}

Albert, C.D., 1964

Cromwell, A.E., and Thurman, E.M., 1993a; 1993b

Dankwardt, Andrea, and others, 1993

Durum, W.H., 1951

Fallon, J.D., and McChesney, J.A., 1993

Goolsby, D.A., and others, 1990

Jordan, P.R., and others, 1964

Jordan, P.R., and Stamer, J.K., 1991

Juracek, K.E., 1992b

Kinnison, H.B., 1925

Kolpin, D.W., and others, 1993; 1994

Landis, E.R., 1960

Mayes, J.L., and Culbertson, Don, 1964

Mayes, J.L., and Diaz, A.M., 1965

Meyer, M.T., 1994

Meyer, M.T., and Thurman, E.M., 1993a; 1993b; $1993 \mathrm{c}$

Mills, M.S., and Thurman, E.M., 1994b

Pope, L.M., and Bevans, H.E., 1984; 1987

Pope, L.M., and others, 1985

Rice, R.C., 1920

Scribner, E.A., and others, 1993; 1993a; 1993b

Stamer, J.K., 1992

Stamer, J.K., and others, 1987

Stamer, J.K., and Zelt, R.B., 1990; 1991

Tanner, D.Q., and others, 1990

Thurman, E.M., 1993a; 1993b

Thurman, E.M., and others, 1991; 1992; 1993

\section{$\mathbf{T}$}

\section{Traveltimes}

Carswell, W.J., Jr., and Hart, R.J., 1985

Jordan, P.R., 1985

Jordan, P.R., and Hart, R.J., 1985

Leonard, R.B., 1969b

\section{Triazine}

Brown, D.E., and others, 1990

Goolsby, D.A., and others, 1990

Juracek, K.E., 1994a

Mills, M.S., and Thurman, E.M., 1992

Scribner, E.A., and others, 1994

Thurman, E.M., 1993a; 1993b

Thurman, E.M., and others, 1990; 1993

\section{Tuttie Creek Lake}

Bevans, H.E., and others, 1993 
$\mathbf{U}$

\section{Unconfined aquifers}

Ehlig, Christine, and Halepaska, J.C., 1976

Meyer, W.R., 1963

\section{Unconsolidated aquifer}

Gutentag, E.D., 1975

Gutentag, E.D., and others, 1978

Pabst, M.E., 1977b; 1978b; 1978c; 1979b

\section{Unsaturated zone}

Juracek, K.E., 1994

Mills, M.S., and Thurman, E.M., 1994

Perry, C.A., $1991 \mathrm{~g}$

Prill, R.C., 1968; 1977

Rutledge, A.T., and Helgesen, J.O., 1989a; 1989b; 1991

\section{Ụranium}

Landis, E.R., 1960

\section{Urban hydrology}

Hejl, H.R., Jr., 1977

James, I.C., II, 1967

O'Connor, H.G., 1973

Peek, C.O., and Jordan, P.R., 1978

Pope, L.M., and Bevans, H.E., 1984; 1987

Pope, L.M., and Hess, L.G., 1989

Pope, L.M., and others, 1983

\section{V}

\section{Verdigris River}

Fader, SW., and Morton, R.B., 1975b

Kansas Water Board, 1958-62

\section{W}

\section{Waconda Lake}

Burnett, R.D., 1984

Burnett, R.D., and Reed, T.B., 1985; 1986

Jorgensen, D.G., and Stullken, L.E., 1981

Kume, Jack, and others, 1985

Reed, T.B., 1981

\section{Walnut River}

Diaz, A.M., 1962b

Kansas Water Board, 1958-62

Leonard, R.B., 1964a; 1964b; 1964c; 1972

Leonard, R.B., and Shah, K.L., 1964

\section{Water development}

Jenkins, E.D., and Pabst, M.E., 1975

Jorgensen, D.G., and others, 1982

Kume, Jack, and others, 1985

\section{Water problems}

Kansas Water Board, 1958-62

\section{Water quality}

Aga. D.S., and Thurman, E.M., 1993a

Aga, D.S., and others, 1993

Baker, C.H., Jr., and Hansen, C.V., 1987; 1988

Bevans, H.E., 1982

Bevans, H.E., and Diaz, A.M., 1980

Bevans, H.E., and others, 1985

Culbertson, D.M., 1963

Diaz, A.M., 1962b; 1965

Dingman, R.J., 1969

Durum, W.H., 1951

Falwell, Ronald, and others, 1990

Feder, G.L., and Krothe, N.C., 1981

Hart, R.J., and Spruill, T.B., 1988

Heck, B.A., and others, 1992

Helgesen, J.O., 1990; 1991

Helgesen, J.O., and Leonard, R.B., 1988

Helgesen, J.O., and others, 1992

Helgesen, J.O., and Rutledge, A.T., 1989

Huntzinger, T.L., 1991

Huntzinger, T.L., and Stullken, L.E., 1988

Juracek, K.E., 1992b; 1994a

Juracek, K.E., and others, 1992

Kenny, J.F., 1993

Kolpin, D.W., and others, 1993

Leonard, R.B., 1964b

Leonard, R.B., and Stoltenberg, G.A., 1972

Lohman, S.W., and Mitchell, Alexander, 1940

Morgan, C.O., and McNellis, J.M., 1969b

Morgan, C.O., and others, 1966

Mueller, D.K., and others, 1991

Myers, N.C., and Bigsby, P.R., 1989; 1990

Myers, N.C., and others, 1993

Parker, H.N., 1911

Plummer, L.N., and others, 1993

Pope, L.M., and Bevans, H.E., 1984; 1987

Pope, L.M., and Diaz, A.M., 1982

Pope, L.M., and others, 1983; 1985; 1988

Rasmussen, P.P., 1994

Rasmussen, P.P., and others, 1994

Ropes, L.H., and others, 1969

Skougstad, M.W., and others, 1979

Spruill, T.B., 1984b; 1987a; 1990a; 1990b

Stamer, J.K., and others, 1987

Stullken, L.E., and others, 1987

Tanner, D.Q., and others, 1990

Thurman, E.M., and others, 1991

U.S. Geological Survey, 1966b; 1967b; 1968b; 1970b; 1970c; 1971b; 1971c; 1972b; 1973b; 1974b; $1975 \mathrm{~b} ; 1976 ; 1977 ; 1978 \mathrm{a} ; 1978 \mathrm{~b} ; 1979 ; 1980 \mathrm{a}$ 1980b; 1981a; 1980b; 1982

Waterman, W.D., 1952 


\section{Water resources}

Albin, D.R., 1975

Bevans, H.E., 1989b

Brewer, L.D., and others, 1994

Burnett, R.D., 1984

Combs, L.J., 1985; 1987; 1989

Combs, L.J., and Powell, K.A., 1992

Darton, N.H., 1905b

Fishel, V.C., and others, 1953

Gannett, Henry, 1898

Geiger, C.O., and others, 1983; 1984; 1985; 1986; $1987 ; 1988 ; 1989 ; 1990 ; 1991 ; 1992 ; 1993 ; 1994$

Hansen, C.V., 1993b; 1993c

Hay, Robert, 1895

Jordan, P.R., 1986a

Lobmeyer, D.H., and Sauer, C.G., 1974

McClain, T.J., and others, 1975

McGovern, H.E., and Combs, L.J., 1979; 1981

Pearl, R.H., and others, 1972

Perry, C.A., 1991d

Petri, L.R., and others, 1964

Powell, K.A., 1994

Smith, W.S.T., 1905

Spruill, T.B., 1984a; 1987b

Trombley, T.J., and Kenny, J.F., 1992

Wolock, D.M., and McCabe, G.J., 1993

\section{Water-resources investigations}

Burnett, R.D., and Reed, T.B., 1986

Byrne, F.E., and McLaughlin, T.G., 1947

Kenny, J.F., and Combs, L.J., 1983

Lohman, S.W., and Burtis, V.M., 1953

McGovern, H.E., and Combs, L.J., 1979; 1981

Newell, F.H., 1895

U.S. Geological Survey, 1964a; 1966d; 1969b; 1972c; 1978 b; 1978c; 1978d

\section{Water supply}

Baker, C.H., Jr., and Kenny, J.F., 1990

Bevans, H.E., 1988

Dunlap, L.E., and others, 1980

Frye, J.C., 1940

Jordan, P.R., and Hart, R.J., 1985

Juracek, K.E., 1992a; 1992c

Kume, Jack, and others, 1979

Lane, C.W., and others, 1962

Latta, B.F., 1948b
Water supply-Continued

Lohman, S.W., 1942

Lohman, S.W., and Mitchell, Alexander, 1940

Lohman, S.W., and others, 1942

Luckey, R.R., and others, 1988

Pope, L.M., and others, $1985 ; 1988$

U.S. Geological Survey, 1955

Williams, C.C., and Lohman, S.W., 1947; 1949

\section{Water temperatures}

Burns, C.V., 1975

Water treatment

Adams, C.D., and others, 1991

Water use

Baker, C.H., Jr., 1979a; 1983

Baker, C.H., Jr., and Kenny, J.F., 1990

Heimes, F.J., and Luckey, R.R., 1980; 1983

Juracek, K.E., 1992c; $1994 \mathrm{c}$

Kenny, J.F., 1986; 1991

U.S. Geological Survey, 1955

Wolff, H.C., 1911

Webster Reservoir

Burnett, R.D., and Reed, T.B., 1985; 1986

Kume, Jack, and others, 1985

\section{Well logs}

Lane, C.W., and Miller, D.E., 1965b

Morgan, C.O., and McNellis, J.M., 1971

Western Interior Plains

Combs, L.J., and others, 1993

Hansen, C.V., and others, 1992

Imes, J.L., $1990 \mathrm{f}$

Kenny, J.F., and others, 1993

Wolf, R.J., and others, 1992

\section{Wet Walnut Creek}

Gillespie, J.B., and others, 1.969; 1970

Gillespie, J.B., and Slagle, S.E., 1972

\section{White River}

Lohman, S.W., and Burtis, V.M., 1953

Lohman, S.W., and others, 1953

U.S. Geological Survey, 1955

Whitewater River

Leonard, R.B., and Shah, K.L., 1964 